


\section{RE-IMAGINING \\ DOCTORAL WRITING}




\section{INTERNATIONAL EXCHANGES ON THE STUDY OF WRITING}

Series Editors: Joan Mullin, Magnus Gustafsson, Terry Myers Zawacki, and Federico Navarro

Series Associate Editors: Ana M. Cortés Lagos, Anna S. Habib, and Matthew Overstreet

The International Exchanges on the Study of Writing Series publishes books that address worldwide perspectives on writing, writers, teaching with writing, and scholarly writing practices, specifically those that draw on scholarship across national and disciplinary borders to challenge parochial understandings of all of the above. The Latin America Section of the International Exchanges on the Study of Writing book series publishes peer-reviewed books about writing, writers, teaching with writing, and scholarly writing practices from Latin American perspectives. It also offers re-editions of recognized peer-reviewed books originally published in the region.

The WAC Clearinghouse, Colorado State University Open Press, and University Press of Colorado are collaborating so that these books will be widely available through free digital distribution and low-cost print editions. The publishers and the series editors are committed to the principle that knowledge should freely circulate. We see the opportunities that new technologies have for further democratizing knowledge. And we see that to share the power of writing is to share the means for all to articulate their needs, interest, and learning into the great experiment of literacy.

\section{RECENT BOOKS IN THE SERIES}

Bruce Morrison, Julia Chen, Linda Lin, and Alan Urmston (Eds.), English Across the Curriculum: Voices from Around the World (2021)

Alanna Frost, Julia Kiernan, and Suzanne Blum Malley (Eds.), Translingual Dispositions: Globalized Approaches to the Teaching of Writing (2020)

Charles Bazerman, Blanca Yaneth González Pinzón, David Russell, Paul Rogers, Luis Bernardo Peña, Elizabeth Narváez, Paula Carlino, Montserrat Castelló, \& Mónica Tapia-Ladino (Eds.), Knowing Writing: Writing Research across Borders (2019)

Sylvie Plane, Charles Bazerman, Fabienne Rondelli, Christiane Donahue, Arthur N. Applebee, Catherine Boré, Paula Carlino, Martine Marquilló Larruy, Paul Rogers, \& David Russell (Eds.), Research on Writing: Multiple Perspectives (2017)

Lisa R. Arnold, Anne Nebel, \& Lynne Ronesi (Eds.), Emerging Writing Research from the Middle East-North Africa Region (2017) 


\title{
RE-IMAGINING DOCTORAL WRITING
}

\author{
Edited by Cecile Badenhorst, \\ Brittany Amell, and James Burford
}

The WAC Clearinghouse

wac.colostate.edu

Fort Collins, Colorado

University Press of Colorado

upcolorado.com

Louisville, Colorado 
The WAC Clearinghouse, Fort Collins, Colorado 80523

University Press of Colorado, Louisville, Colorado 80027

(C) 202I by Cecile Badenhorst, Brittany Amell, and James Burford. This work is licensed under a Creative Commons Attribution-NonCommercial-NoDerivatives 4.o International License.

ISBN 978-1-64215-134-3 (PDF) | 978-1-64215-135-0 (ePub) | 978-1-64642-271-5 (pbk.)

\section{DOI 10.37514/INT-B.2021.1343}

Produced in the United States of America

Library of Congress Cataloging-in-Publication Data

Names: Badenhorst, Cecile, I962- editor. | Amell, Brittany, I985- editor. | Burford, James, I985- editor.

Title: Re-imagining doctoral writing / edited by Cecile Badenhorst, Brittany Amell, and James Burford.

Description: Fort Collins, Colorado : The WAC Clearinghouse ; Louisville, Colorado : University Press of Colorado, [202I] | Series: International Exchanges on the Study of Writing / series editors, Joan Mullin, Magnus Gustafsson, Terry Myers Zawacki, and Federico Navarro | Includes bibliographical references.

Identifiers: LCCN 2021035788 (print) | LCCN 2021035789 (ebook) | ISBN 9781646422715 (Paperback) | ISBN 978I642151343 (PDF) | ISBN 9781642151350 (ePub)

Subjects: LCSH: Dissertations, Academic--Authorship.

Classification: $\mathrm{LCC} \mathrm{LB}_{2369} \cdot \mathrm{R}_{3} 2 \mathrm{O2I}$ (print) | LCC LB2369 (ebook) | DDC

$808.06 / 6378^{--\mathrm{dc} 23}$

LC record available at https://lccn.loc.gov/2021035788

LC ebook record available at https://lccn.loc.gov/2021035789

Copyeditor: Karen Peirce

Design and Production: Mike Palmquist

Cover Photo: "Salvage Image" by Cecile Badenhorst

Series Editors: Terry Myers Zawacki, Magnus Gustafsson, Joan Mullin, and Federico Navarro

Series Associate Editors: Ana M. Cortés Lagos, Anna S. Habib, and Matthew Overstreet

The WAC Clearinghouse supports teachers of writing across the disciplines. Hosted by Colorado State University, and supported by the Colorado State University Open Press, it brings together scholarly journals and book series as well as resources for teachers who use writing in their courses. This book is available in digital formats for free download at wac.colostate.edu.

Founded in 1965 , the University Press of Colorado is a nonprofit cooperative publishing enterprise supported, in part, by Adams State University, Colorado State University, Fort Lewis College, Metropolitan State University of Denver, University of Colorado, University of Northern Colorado, University of Wyoming, Utah State University, and Western Colorado University. For more information, visit upcolorado.com. 


\section{\ Dedication}

We dedicate this book to anyone who needs to re-imagine doctoral writing in order to become a doctoral writer. 


\section{\& Contents}

Dedication....................................

Acknowledgments............................... ix

Introduction: The Case for Re-imagining Doctoral Writing. . . . . . . . . 3

James Burford, Brittany Amell, and Cecile Badenhorst

Section One. The Call to Re-imagine Doctoral Writing . . . . . . 29

1 Writerly Aspirations and Doctoral Education: Beyond Neoliberal

Orthodoxies.....................................31

Catherine Mitchell (Taranaki)

2 Re-imagining Doctoral Writings as Emergent Open Systems. . . . . . 49 Julia Molinari

3 Ph.D. by Publication or Monograph Thesis? Supervisors and

Candidates Negotiating the Purpose of the Thesis when Choosing

Between Formats................................ 71

Signe Skov

Section Two. Concepts and Tensions of Doctoral Writing . . . . . 87

4 Borders and Tensions in the Context of Doctoral Writing. ......... 89

Susan van Schalkwyk and Cecilia Jacobs

5 Queer Path-Making: Expressing or Suppressing Creativity in Arts

Doctoral Writing. . . . . . . . . . . . . . . . . . . . . . . . . . . . 107

Steven Thurlow

6 Meta-Generic Imaginings: Using Meta-Genre to Explore

Imaginings of Doctoral Writing in Interdisciplinary Life Sciences. . . . 125

Sara Doody

Section Three. Re-imagining Doctoral Writers and Their

Others......................................... 143

7 Embodiment, Relationality, and Constellation: A Cultural Rhetorics Story of Doctoral Writing. . . . . . . . . . . . . . . . . . . . . . . 145

Matthew B. Cox, Elise Dixon, Katie Manthey,

Maria Novotny, Rachel Robinson, and Trixie G. Smith 
8 Vā and Veitapui as Decolonial Potential: Ongoing Talatalanoa and

Re-imagining Doctoral Being and Becoming ............... 167 David Taufui Mikato Fa'avae

9 Writing a Doctoral Thesis in a Non-Western Voice . . . . . . . . . . 185 Sharin Shajahan Naomi

10 Decentring the Author/Celebrating the Typist in Doctoral Thesis Acknowledgements . . . . . . . . . . . . . . . . . . . . . . . 201 Frances Kelly, Catherine Manathunga, and Machi Sato

Section Four: Writing a Re-imagined Doctoral Thesis. . . . . . . 215

11 Re-imagining Doctoral Writing Through the Visual and Performing Arts. . . . . . . . . . . . . . . . . . . . . . . . . 217

Louise Ravelli, Sue Starfield, and Brian Paltridge

12 Fictional Writing in Doctoral Theses: The (re)Engagement of

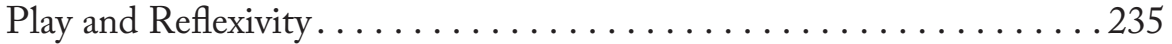
Will Gibson

13 The Curious Predicament of an (un)Comfortable Thesis

Conclusion: Writing with New Materialisms . . . . . . . . . . . . 253 Toni Ingram

Conclusion: The Unfinished Business of Re-imagining Doctoral

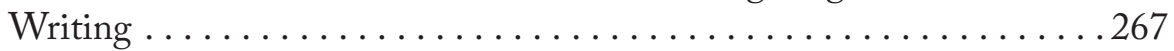
James Burford, Brittany Amell, and Cecile Badenhorst

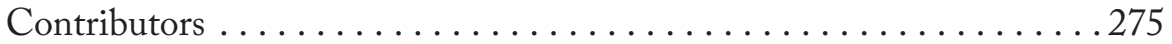




\section{$\S$ Acknowledgments}

It has been a privilege to work on this edited collection despite the fact that much of the work has taken place during a pandemic when, for many of us, our lives have been turned inside out. The series editors Terry Zawacki, Joan Mullin, Magnus Gustafsson, and Federico Navarro have been exceptionally helpful, as has been founding editor and publisher Mike Palmquist. Terry, in particular, has guided us with gentle encouragement and thoughtful suggestions throughout the process. We also thank the contributors for their work on chapters and for their collegial approach to this project. It has been a pleasure to work with you all, and we look forward to many years of collaborations in the future. We would also like to thank all the readers who read earlier drafts of pieces of this collection. We are grateful for your careful work.

Cecile: I would like to acknowledge the support from Memorial University for assistance in the preparation of this manuscript and in particular for the Publications Subventions Program grant. I also want to thank my co-editors, Britt and Jamie, for a most enjoyable journey. Our virtual meetings became a highlight for me. I'm also extremely grateful to both of them for carrying the load when I became ill. They conveyed their compassion and care in multiple ways.

Britt: As I type this on my phone (with one hand, while feeding my new baby), I am astounded at what can be accomplished when academics come together to care-fully collaborate. As authors and editors, we have been through births, deaths, sickness (hello Covid-rg!), health, layoffs, new jobs, as well as dissertation endings (congrats!), beginnings, and somewhere in between. I am grateful to my co-editors who have sustained me in more ways than I could possibly detail. I am grateful to the authors, who gracefully took on rounds of editing and review in order to push this piece further. I am grateful to the Algonquin Nation whose territory includes the Ottawa River watershed, which nurtures and sustains my life and the lives of my kin. Finally, I am grateful to my human, Sean Botti, whose countless hours of visible and invisible labour has contributed to making this project a reality.

Jamie: I am grateful to so many people who have been a part of bringing this collection together. I would like to thank my co-editors, Britt and Cecile, for their rigour, generosity, and care. The fact that we have edited this book from different corners of the world has frequently opened up interesting juxtapositions in time and season and in terms of how we think about doctoral education and writing. I am grateful to chapter authors for working with us 
Acknowledgments

and engaging so richly with each other's work. And I am grateful to friends and colleagues who encouraged and supported me throughout. 


\section{RE-IMAGINING \\ DOCTORAL WRITING}





\title{
Introduction: The \\ Case for Re-imagining Doctoral Writing
}

\author{
James Burford \\ La Trobe University \\ Brittany Amell \\ Carleton University \\ Cecile Badenhorst \\ Memorial University
}

Doctoral education is a practice undergoing considerable transformation. Over recent decades, doctoral education has been re-positioned as an important contributor to national economic success within a global knowledge economy (Cuthbert \& Molla, 2015), doctoral enrollments continue to expand across many global contexts (Castelló et al., 2017; McCulloch \& Thomas, 2013), and new forms of the doctorate have emerged internationally (Lee et al., 2009), such as professional doctorates in education (Ed.D.), social work (D.S.W.), and nursing practice (D.N.P.). As a result, international organizations (e.g., the Organization for Economic Co-operation and Development $[\mathrm{OECD}]$ ), governments, and higher education institutions alike have become increasingly attentive to doctoral "problems," such as persistently high attrition rates (Bair \& Haworth, 2005), lengthy times to submission (Starke-Meyerring et al., 20I4), and ongoing concerns about graduate employability (Cuthbert \& Molla, 2015).

Writing is another area where troubles are seen to belong, with concerns expressed about the academic literacies of an increasingly large and diverse doctoral cohort, worries about the effectiveness of supervision pedagogies for doctoral writing, and questions about the transferability of writing capacities to industry settings. As a result, institutional policymakers have become increasingly interested in surveilling and regulating the written texts and writing productivity of doctoral students (Burford, 20I7a). Added to this picture is the growing intensification of the doctorate itself, with students expected to publish not only a thesis/dissertation often within a normative timeframe, but also a larger number of other texts that are seen to "count," such as book 
chapters and journal articles (Huang, in press). ${ }^{1}$ This is not to mention the growing assortment of written texts that doctoral students are encouraged to produce, ranging from funding applications to blog posts, opinion pieces to tweets. Given this complex picture, it is timely to explore how doctoral writing is imagined as we begin the third decade of the 2Ist century. Understanding the varied ways in which doctoral writing is currently imagined also offers us opportunities to consider how it may be re-imagined otherwise.

In a context where many higher education stakeholders are now attuned to the importance of doctoral writers and their written outputs, doctoral writing has also become an increasingly well-researched area of inquiry. While once it might have been commonplace to lament the neglect of doctoral writing research, we no longer think this is a helpful position from which to begin. A cursory glance across library shelves or journal alerts will reveal a wealth of publications on doctoral writing, including many books (see McCulloch, 20I8). For example, a number of books locate doctoral writing within the complex process of forming a scholarly identity (e.g., Aitchison et al., 2oro; Kamler \& Thomson, 2006; Lovitts, 2007; Walker \& Thomson, 2010). These books are often intended as guides for students and supervisors, providing resources and strategies to navigate the writing process as well as other challenges in the doctoral journey (Dunleavy, 2003). ${ }^{2}$

A number of recent books have also examined the complexity of practices, policies, and pedagogies surrounding master's and doctoral students'scholarly writing (e.g., Aitchison \& Guerin, 20I4; Badenhorst \& Guerin, 20I6; Carter et al., 2020). In Writing Groups for Doctoral Education and Beyond: Innovations in Practice and Theory, edited by Claire Aitchison and Cally Guerin (20I4), authors describe collaborative writing pedagogies for doctoral students through a conceptual interrogation of these practices. Cecile Badenhorst and Cally Guerin's (2016) edited collection, Research Literacies and Writing Pedagogies for

1 Given the international scope of this volume, we have encouraged authors to use the language that is common in their context. This means that across the volume there will be descriptions of doctoral theses and doctoral dissertations. There will also be significant differences in the organisation of doctoral education, with some chapters writing from a context which assumes doctoral coursework, and others writing from a context where "the thesis" is the single examinable doctoral text. This is reflective of the wide diversity that exists across doctoral education globally.

2 Other texts foreground the unprecedented change that doctoral education has undergone over the past several decades in response to major shifts within and outside of the university. For instance, Boud and Lee's (2009) edited text Changing Practices of Doctoral Education and Lee and Danby's (2012) edited book Reshaping Doctoral Education: International Approaches and Pedagogies address these changes. 
Masters and Doctoral Writers, also takes up these debates, highlighting pedagogical experiences from multiple vantage points (student, writing instructor, writing researcher, and thesis supervisor). Doctoral education researchers, such as Frances Kelly (20I7), have also traced imaginaries of the Ph.D. by asking doctoral students to share stories about their doctoral experiences. Because writing is so closely associated with the Ph.D., imaginaries of writing and writers were integral to Kelly's work. Across her 2017 book The Idea of the PhD: The Doctorate in the Twenty-First-Century Imagination, we can trace various imaginaries of writing, including the "scholar working quietly and alone on a thesis, with time to do so" (p. 34), writing as a "difficulty to be overcome" and as a "risk to be managed" (p. 33), and writing as bound up with "ideas and imaginaries about being a researcher or a scholar" (p. 34). We have not presented a comprehensive list of texts here by any means, but we hope these examples illustrate the increasingly established nature of doctoral writing research.

Doctoral writing has not only blossomed as an object of research and advice, it has also emerged as an important locus of institutional work and public academic debate. An object of institutional interest, if not concern, doctoral writing is often implicated in practices of performance review and the metricization of research productivity (Burford, 20I7b). For example, in many Western Anglophone institutions, doctoral supervision (including writing pedagogies) and doctoral writing outputs are practices which draw significant institutional attention and in some cases resources, particularly when "problems" emerge. Though this varies by context, specialists are often employed to work one-on-one with doctoral writers and/or to coordinate streams of learning around doctoral writing. Social learning opportunities, such as "Shut Up and Write" collectives (Fegan, 2016), writing groups (Beasy et al., 2020; Swadener et al., 2015), doctoral writing retreats (Davis et al., 2016), and other initiatives, have expanded rapidly (see Lawrence \& Zawacki, 2or8).

Doctoral writing is also a topic that draws widespread public debate across social platforms, including blogs such as the DoctoralWritingSIG blog (https://doctoralwriting.wordpress.com/; see Carter et al., 2020; Guerin et al., 2020), the Thesis Whisperer blog (https://thesiswhisperer.com/), and the Patter blog (https://patthomson.net/); on Twitter with hashtags such as \#docwri and \#doctoralwriting; on YouTube accounts such as Cecile Badenhorst's (https://www.youtube.com/channel/UCDX1Zhpn7iJcw9BdgzUXWbA); and on podcasts such as the Tara Brabazon Podcast (https://tarabrabazon.libsyn.com/). There are also special interest groups organized around doctoral writing, including the Doctoral Writing SIG community, which holds regular gatherings and operates as a stream at the biennial Quality 
in Postgraduate Research (QPR) conference in Australia; the International Doctoral Education Research Network (IDERN), which meets every second year in association with different international conferences; and the Consortium for Graduate Communication (CGC) network in the US.

As our brief survey suggests, doctoral writing has increasingly become a practice of concern for institutional stakeholders and supervisors worldwide as well as an increasingly established area of research and institutional practice.

\section{Why This Book?}

Despite the importance attributed to doctoral writing for developing scholars, we have a limited understanding of the extent to which conceptualisations of doctoral writing are shared or contested, how ideas of doctoral writing have shifted over time, or where imaginings of the future of doctoral writing might take us. In this book, we pursue these questions. We also explore what might happen if we begin thinking about doctoral writing without imagining a vast absence in front of us. We hope that beginning from a place in which doctoral writing is seen as a rich, and increasingly deep, area of scholarship might orient our inquiries in some interesting ways.

We chose the title of this book, Re-imagining Doctoral Writing, in order to encourage contributors to offer different tools and approaches that might enliven our ideas of what doctoral writing may be and how it might be researched. While we sought out historical studies that tracked how imaginings of doctoral writing and doctoral writers have changed over time, we also sought to uncover what new doctoral writing imaginings have arisen in the 2Ist century as well as why they have arisen and what their impacts might be. We sought out work on the imaginings of different stakeholders as well as accounts that explore how doctoral writing arises in media and cultural texts. We encouraged imaginings of doctoral writing that saw it as a spatialized, embodied and felt practice - as one bound up with pleasures and possibilities as well as pains. And we sought to bring doctoral writing research into contact with ideas that might extend it, such as feminist, queer, critical race, post-humanist, and decolonial approaches.

Our naming of the book also reflects our view that doctoral writing is too often understood in instrumental ways that would benefit from much more imagination. Oftentimes there is a focus on the pragmatics of "what works" in doctoral writing policies, practice, and pedagogy. Researchers commonly take for granted what "doctoral writing" is and proceed on the basis that knowledge about doctoral writing that is situated in one context is generalizable to others. The title Re-imagining Doctoral Writing reflects our belief that a 
questioning stance would be a helpful counterweight. While there is a clear demand for practical advice to be offered to students and supervisors (e.g., Aitchison, 2015; Aitchison \& Lee, 2006; Kamler \& Thomson, 2006; Scevak, 2006; Thomson \& Kamler, 20I6), and we ourselves have contributed to this genre (Amell \& Badenhorst, 20I8; Badenhorst et al., 20I2; Badenhorst et al., 2015; Burford, et al., 2018), there are other ways to think about doctoral writing that we think ought to be nurtured, too. By positioning the collection as in pursuit of varying conceptualizations of doctoral writing, we hope to tug future scholarship in this direction.

Re-imagining Doctoral Writing brings together a range of scholars from different world regions and disciplines, each of whom brings a distinctive approach to bear on the question of how doctoral writing is imagined. In the remainder of this introductory chapter, we trace the genesis of this project and highlight the aims and purpose of the volume. We also provide brief descriptions of each chapter and aim to give a sense of how readers can use the book-in part or in whole-to re-imagine doctoral writing and doctoral writing research.

\section{Doctoral Writing Research}

We have puzzled over how best to describe the current state of doctoral writing research. Alistair McCulloch (2018) has suggested that doctoral education studies is a discipline, but whether doctoral writing research can be described as such is a question that remains open for debate. As editors, we have debated whether to describe doctoral writing as a "field" or "sub-field;" an "area;" a "community of practice;" a "territory," "zone," or "domain;" or umpteen other metaphors that might be invoked to give us a foothold in our object of inquiry. While in higher education research we see descriptions of a "scattered field" or "theme" (Daenekindt \& Huisman, 2020) or "isolated islands" of scholarship (Macfarlane, 20I2) rather than a discipline, we have settled on describing the study of doctoral writing as an area of inquiry. It is our view that the interdisciplinary and unsystematic nature of scholarly involvement in doctoral writing precludes it from being described otherwise at this point in time. Having dealt with the difficult question of how to think our way toward our object, there is the equally challenging question of how we might characterize it.

When approaching doctoral writing, some scholars highlight the doctoral in doctoral writing-foregrounding theories and frameworks of doctoral education and higher education more broadly. Others shine their spotlight on the writing in doctoral writing-foregrounding theories and frameworks of 
writing within the context of doctoral education. Yet doctoral and writing are inseparable in studies of doctoral writing, and we agree with Claire Aitchison and Anthony Paré (2012), who have argued that "writing must be in discussions about doctoral education" and "at the center of curriculum and pedagogy for doctoral education" (p. 22).

How researchers conceptualize doctoral writing appears to depend on a number of variables. In our reading across this area of inquiry, we have identified three interlayered components: geography, discipline, and the predominant "paradigms" that are available for conceptualisations of writing (Lillis $\&$ Scott, 2007, p. 9). We wish to draw attention to three broad approaches that prevail with regards to how doctoral writing is theorized in the literature, which are (a) approaches that draw on social and rhetorical theories of writing called writing studies, (b) approaches that are influenced by academic literacies, and (c) approaches that build on sociocultural theories of learning (particularly the cognitive apprenticeship and communities of practice approaches) and that are drawn largely from higher education research.

Despite their differences, these three approaches to researching doctoral writing have much in common. For one, they are all interested in understanding social practices - a diverse set of social elements that come to be associated with certain realms of social life (Fairclough, 2003). Practices are patterned and habitual ways of thinking, behaving, feeling, and acting. For instance, an academic literacies approach might see academic writing as a social practice and, as such, seek to understand how writing becomes routinized over time and mediated by power, privilege, and context. Likewise, researchers interested in understanding how doctoral students develop into or "become" academics might also be interested in understanding how academic practices are generated, sustained, and taken on by novices over time. Researchers who draw on socio-rhetorical understandings of writing might similarly be interested in academic practices, but they may look to the role that writing plays in generating, maintaining, and sedimenting academic practices over time.

While in the following sections we aim to mark a number of routes researchers may take as they think about doctoral writing, we recognize that many scholars will combine these approaches in their work.

\section{Writing Studies}

Doctoral writing scholars situated in Canada and the United States appear to more commonly draw on theories from writing studies and tend to frame writing from a socio-rhetorical approach. While writing studies researchers have shifted over the past several decades with regards to how they theorize 
writing, most relevant for understanding doctoral writing has been the shift from seeing writing as a product and writing as a process towards viewing writing as both social and socially constructed (Freedman \& Medway, 1994; Freedman \& Pringle, I980; Paré, 2009).

A socio-rhetorical view of writing understands that writers use language to get things done, which is to say that writing and language are inseparable and rhetorical (Freedman \& Medway, 1994; Paré, 2009). As such, writing and writers cannot be separated from the social and rhetorical situation-which includes an understanding of the community or audience one is writing for; the exigencies and purposes that one has for writing; and the social situation and its inherent pressures, complications, and dynamics (Reither, 1985; Paré, 2009; Dias et al., 1999).

Socio-rhetorical scholars of writing also argue that we need to consider the written product - they are, after all, speaking to the social-rhetorical situation via genres, or typified, recurring, and recognizable forms (Artemeva, 2006; Freedman \& Medway, 1994). Additionally, scholars ought to pay attention to the processes of writing - in other words, we need to understand what writers actually do when they write, as well as the role that others can play in the writing process (Paré, 2009). However, we should also consider the interconnected ways in which writing is linked to other texts and communities. Academic writing, then, is inseparable from academic reading, inquiry, and community, since what counts as relevant writing and research will depend on what is valued by the discourse community the writer is connected with or attempting to connect with - and the extent to which the writer grasps what is valued. For example, writing from Canada, Doreen Starke-Meyerring and colleagues (2014) have drawn on North American notions of genre (as typified, recurring responses to social situations) to consider how institutions discursively frame doctoral writing. Similarly, Susan Lawrence and Terry Myers Zawacki's edited collection Re/Writing the Center: Approaches to Supporting Graduate Students in the Writing Center (2018) provides targeted support for graduate students to meet the expectations of their audiences.

\section{Academic Literacies}

The academic literacies approach began in the UK, evolving out of New Literacies Studies (Lea \& Street, I998; Lillis \& Scott, 2007; Street, 20I0, 2013), but has since been taken up by researchers across Europe, in South Africa, as well as in Australia and Aotearoa New Zealand. Much of this research branches out of higher education studies and doctoral education research in particular. 
Like a socio-rhetorical view of writing, academic literacies researchers also understand writing as situated. However, while writing studies emerged in the US from a history of teaching writing through composition classes, academic literacies emerged more recently as a critical response to the massification of higher education and "powerful and restricted...official discourses" that frame/d "non-traditional" students' language and writing use from a deficit view (Lillis \& Scott, 2007, p. 6). Academic literacies researchers take a "social practices" approach that focuses on the socio-cultural, disciplinary, and institutional contexts in which literacies take place (Kamler, 2003), and the underlying reasons why practices often become obscured as "business as usual" and buried in invisibility.

An academic literacies perspective foregrounds the experiences of writers against a backdrop that includes a critical consideration of power, institutional practices, the epistemological nature of academic writing, and the implications that these have for identity and meaning making (Lea \& Street, I998; Lillis \& Scott, 2007; Lillis et al., 20I5). For those working with an academic literacies approach, writing and identity are deeply linked, so much so that asking a writer to change an aspect of their writing can feel like a reflection on their identity. This is so, they have argued, because

academic writing is not merely an issue of correct grammar or individual motivation, but rather an identity issue where students require access to the subtle and normalized rules of Western academic discourse and epistemological access to the processes of knowledge production. (Boughey, 2002, as cited in Doyle et al., 20I8, p. 2).

\section{Sociocultural Theories of Learning}

Sociocultural theories of learning are often used in conjunction with academic literacies and socio-rhetorical approaches to think about the development of doctoral scholars and the integral role that writing plays in doctoral students' development. Doctoral student "development" discourse has emerged, at least in part, from sociocultural perspectives in education that stem from theories of situated learning and cognitive apprenticeship (Lave \& Wenger, I99I; Rogoff, I990), where apprenticeship is a key means through which the craft of research is learned. The idea of apprenticeship in academia views research as a constellation of activities that are grounded in situated knowledge and tacit skills, practice, and ways of being (Wegener \& Tanggaard, 2013). 
Those working within a sociocultural perspective often find theories of workplace learning to be particularly relevant for understanding doctoral writing because, unlike undergraduate students or many master's students, doctoral students are required to "participate in the ongoing knowledge-making endeavors of their research communities" (Paré et al., 20II, p. 2I7). This entails seeking opportunities for mentorship that can be shared across a network, for example by supervisors, committee members, and so forth (Paré et al., 2orr). Sociocultural theories of learning are often deployed to think about pedagogies for supervision, doctoral "becoming," and academic identity development (Aitchison, 20I5; Badenhorst \& Guerin, 20I6; Carter \& $\mathrm{Ku}-$ mar, 20I7; Inouye \& McAlpine, 20I7; Kamler \& Thomson, 2006; Maher et al., 2008; Wegener \& Tanggaard, 2013). For instance, Jean Lave and Etienne Wenger (199I) posited that a novice learns how to participate in a community of practice by first performing legitimate tasks. In particular, Lave and Wenger's research focused on how apprentices develop their skills starting as newcomers and moving toward becoming "old-timers," with a concomitant shift in their identity as experts (Artemeva, 2orr; Badenhorst \& Guerin, 20I6). In academia, the idea of apprenticeship helps to explain how research and academic writing practices are passed on via forms of mentoring such as the supervisory relationship (Wegener \& Tanggaard, 20I3). Like writing studies and academic literacies, sociocultural theories of learning (e.g., cognitive apprenticeship and situated learning) assume development and learning are socially situated.

Although there is a growing number of fora for discussion of doctoral writing in each of these approaches, scholars sometimes work in different silos, perhaps unaware of the depth of doctoral writing scholarship that other researchers are undertaking. One of the goals of this volume is to bring these different ways of understanding doctoral writing into contact to see what resonates and which sparks of possibility might flicker.

\section{Who Are We?}

As editors, we were drawn to the idea of this book because we saw it as an opportunity to examine doctoral writing beyond the "how-to," where much of our own work is also based (Amell, in press; Badenhorst \& Amell, 2019; Burford et al., 2018). The how-to framing frequently begins from the position of seeing writing-as-a-problem and is often oriented to the practicalities of getting students through a high stakes educational practice. In this volume, we want to explore doctoral writing as something other than pragmatics. 
We bridge some of the geographical and disciplinary divides that we have described in the previous sections of this chapter. Jamie is from Aotearoa New Zealand and brings context from the Antipodes and Global South from his work in universities in Thailand and Australia. He is a higher education researcher who focuses on doctoral education and researcher development. When it comes to writing, he is particularly interested in how this practice connects to wider transformations that are shaping universities, such as internationalization, neoliberalism and metricization. Jamie describes writing as a window he is often looking through in order to understand what is going on in the worlds of doctoral students and their supervisors. Brittany, from Canada and based in the discipline of applied linguistics and discourse studies, found herself situated between literacy studies and writing studies. Her curiosity led her to build bridges between the two. Her inquiries tend to focus on how we define and understand scholarship, which includes doctoral writing, and the role these definitions and understandings play in helping universities better respond to evolving realities both beyond and within the walls of the campus. Cecile, originally from South Africa and now working in Canada, comes from a background in higher education and academic literacies and tends to focus on issues of power and difference and how they relate to doctoral writing. She has had firsthand experience in trying to find common language across these geographical contexts. As a team, we also bridge differences across career stages. Jamie is an early career researcher, Brittany, a doctoral candidate at the time of writing, and Cecile, an established scholar.

How did we come together as a team? Brittany, in her endeavor to build connections and understand how academic literacies overlapped with writing studies, contacted Cecile. They began a collaboration exploring doctoral writing, which resulted in co-editing a special issue of Studies in Discourse and Writing/Rédactologie titled "Play, Visual Strategies \& Innovative Approaches to Graduate Writing" (Amell \& Badenhorst, 20r8). Jamie was one of the authors in the special issue (Burford et al., 2018). Individuals are often drawn to like-minded people, and the three of us connected immediately. We began with small conversations, which led to much longer, detailed conversations. One of the greatest pleasures about working together is that we introduce each other to new ways of thinking about doctoral writing.

\section{Why Re-imagining?}

Increasingly, time compression, financial constraints, and poor job prospects have characterized doctoral experiences in many contexts in the Global North (Aitchison \& Mowbray, 2015; Burford, 2018). They have also impacted 
available conceptualizations of doctoral writing (see Manathunga, 20I9). Often, discussions about doctoral writing have revolved around rhetoric, craft, and technique, but essentially have been steeped in a matter of know-how. In this book, we aim to open a different space to think about doctoral writing. Perhaps we can create space to renew thinking, looking for not only choices that are made but also those that are not made. Can we see the traces, tracks, footprints of what might have been and what could be? Our imaginings may vary and may well remain unrealizable, but as long as we are pushing on the structures that confine us, something fresh is bound to happen. What must be renewed? What deserves continuity? Are there paradoxes in emerging imaginings? Where do we begin?

\section{Doctoral Writing: Shadows and New Horizons}

In a recent article, Søren Bengtsen and Ronald Barnett (2017) encouraged critical university studies scholars to confront the dark side of higher education, aspects of which "may be dim, obscure or caught in a blind angle" (p. II5). We attend to this call with a particular interest in considering some shadier dimensions of doctoral writing. For example, when it comes to the teaching of doctoral writing, doctoral pedagogues are often positioned as helpful problem solvers with solutions to simplify writing conundrums. However, doctoral writing is a context where ideas are aired, fought over, and debated. As a consequence, doctoral writing is often not "nice" but is instead politically textured and devilishly complicated. We believe there is a need to unpack how pedagogies of doctoral writing are implicated in such struggles. As editors, we are interested in a number of related questions. Where is the turbulence and the mess of doctoral writing captured? Who considers the relation of cruel optimism (Berlant, 20II) that can be discerned in the fantasies that students bring to doctoral writing? Who counts the dreams that remain unfulfilled? Who tracks the disciplinary power of writing, where writing is de-politicized and writers lose their voice? What about the shadow side of academic integrity and the unfair practices that some engage in? Since doctoral writing is the space where ideas are materialized on the page, how does this affect the intersecting identity politics (e.g., race, gender, sexuality, indigeneity) of doctoral writing? What about bodies? Here we are including the ones who ache, the ones who quit, the ones who fail. As we write this introduction, protests about racism, systemic inequalities, and police brutality are taking place in cities around the world. Demands for sovereignty, respect, justice, dignity, and ethical relationality are seared, as they ought to be, in the forefront of our minds. How might this shape possible meanings of doctoral writing? What of the 
unprecedented global pandemic of COVID-I9 we have all been facing? How will these circumstances affect our experiences of researching, teaching about, supervising, and engaging in doctoral writing?

As we turn to think about the imaginaries of doctoral writing, we should also keep our eyes peeled for those new horizons, the innovations to the forms and practices that are shaping doctoral writing now. What impact are new creative and experimental genres having on doctoral writing? How do the knowledge projects of Indigenous and Southern doctoral scholars push on the borders of what writing, texts, and writers might be? And, what about the joys of doctoral writing? We ought to chart its rich pleasures, the desires writers bring to it, the answers readers might find in reading doctoral texts (Burford, 20I4). We ought to attend to the moments when doctoral researchers find themselves participating in the wonderful privilege of knowledge production, and we ought to attend to those people who, through their writing, find themselves part of a community of scholars. What we are gesturing to here are openings, or at least the possibility of openings. We are trying to hold space for the possibility, too, of an ontology of writing, the powerful experience of writing as a way of being (Yagelski, 2orI). Sometimes we are romanced by our writing, and sometimes we romance our writing - the thrill of chasing an idea down a rabbit hole, only to emerge with another idea that has changed us forever. An excerpt from Brittany's personal research journal illustrates an often-unvoiced relationship with doctoral writing:

I can think of one set of papers I had to write earlier on in my doctorate. It was like a polyamorous relationship. I flirted openly with ideas and concepts. I slept with them all. Some ideas were more interesting than others. I was drawn to them, or perhaps they were drawn to me.... Other ideas continued to attract me, even though the feeling didn't seem mutual. These unrequited hot messes were all the things I knew I didn't want to know-they refused to play nicely, bordering on frantic. They didn't show up when they promised to. They wounded old wounds, coming when they liked and leaving far too soon. They left impressions-consensual raw welts that rigorously point me to the places where "not everything is composed" (Alexander \& Rhodes, as cited in Waite, 20I7, p. 6), where resistance is poetic, practical, necessary, and desirable.

In research accounts of doctoral writing, we hear about how much doctoral writing hurts (e.g., Aitchison \& Mowbray, 2013)—the excerpt from Brittany's 
notebook suggests that perhaps writers might be drawn to that pain, because it is also pleasurable at times.

\section{Overview of the Book}

What imaginings do doctoral students, supervisors, institutions and other stakeholders bring to the practice of writing? What are the dominant imaginings of doctoral writing, and why might these be contested? How might we approach doctoral writing pedagogy, practice, and policy in more imaginative ways? In addressing these (and other) questions, Re-imagining Doctoral Writing builds important links between doctoral education research, doctoral writing scholarship, rhetoric, composition and writing studies, and academic literacies.

The fresh contribution that this edited collection brings to existing discussion is the focus on re-imagining. This contribution is manifested through two threads that run throughout Re-imagining Doctoral Writing. First, the book traces the ways in which doctoral writing is currently imagined. The book as a whole asks, "When we talk about doctoral writing, what do we mean?" This question arises from the fact that "doctoral writing" is used to signify a number of different ideas and practices. This is both exciting and a challenge. It means that doctoral writing is a concept which is open to fluidity and mobility, and it can also be simplified and restricted. The book showcases the work of researchers who are working with various imaginings of doctoral writing.

The second thread that runs through the collection as a whole is the discussion of how doctoral writing may be re-imagined otherwise. Like others, we are committed to imagining not only what doctoral writing is, but re-imagining what it can be (Paré, 20I7, 20I9), as well as how we might be more imaginative in our approaches to doctoral writing as researchers, supervisors, and institutions. By homing in on the concept of imagining, we encouraged participating authors to focus on the illimitability, paradoxes, ambiguity, freedom, and mystery of doctoral writing as well as personal processes of divergence and agency (Das, 20I2). With the focal concept of "imagining," we aim to evoke and provoke cross-border dialogue and to foster international connections and exchange. We see current research on doctoral writing as a site of creative invention, and it is this volatile space that we would like to examine as it is unfolding (see also Ravelli et al., 20I4). Taken as a whole, this book serves both as a foundation for understanding the different ways in which we might understand "doctoral writing" and as a site for envisioning how doctoral writing could be imagined otherwise.

Following this introductory chapter is Section One of the book, The Call to Re-imagine Doctoral Writing. This section features three chapters from 
researchers based in Aotearoa New Zealand, the United Kingdom, and Denmark. Each of these chapters enacts or examines various calls to re-imagine doctoral writing. Across these three chapters are calls for researchers to engage in re-imagining, whether this is to explore doctoral student imaginaries that may exceed the confines of limiting framings or to imagine doctoral writing itself in more expansive ways. These chapters also examine how doctoral students and supervisors may call for, and resist, re-imaginings of the form of the doctoral thesis.

The first chapter in this section, "Writerly Aspirations and Doctoral Education: Beyond Neoliberal Orthodoxies" by Catherine Mitchell (Taranaki), examines the place of "the writer" within imaginaries of doctoral education. Drawing on an empirical study with first-in-family doctoral students in Aotearoa New Zealand, Mitchell outlines the ways in which investments in the idea of "the writer" may exceed narrow neoliberal orthodoxies that shape prevailing doctoral education imaginaries. Across Mitchell's work, ideas of writers, storytellers, and writerly works are shown to inform both university imaginaries and the formation of doctoral aspiration. This chapter draws attention to the ways in which the discursive and imaginative space of doctoral education and the university itself have not been completely captured by neoliberalism. In Mitchell's chapter, the aspiration to become doctoral remains, for many, bound up with writing and with what it is to be a writer. As such, Mitchell's chapter calls doctoral writing researchers to pay close attention to often unarticulated dreams and desires that doctoral researchers may bring to the process of becoming a writer.

Julia Molinari's chapter "Re-imagining Doctoral Writings as Emergent Open Systems," draws on critical realism, complexity theory, and emergence in support of the call to re-imagine doctoral writing. Molinari argues that academic writing in general is a complex open and emergent social system that can change. She then offers several reasons for re-imagining doctoral writing. The first is that academic writings already exhibit considerable diversity. This suggests that the conditions of possibility for re-imagining them are already in place, providing a conceptual space from which to further imagine. Second, there are epistemic reasons for re-thinking how doctoral students may wish to write, as evidenced by research on socio-semiotics. Molinari then introduces several examples of doctoral writers who have re-imagined their writing in order to advance their knowledge production. To explain how change in social phenomena is possible and how it can continue to be justified, Molinari draws on the theory of complex permeable open systems. By re-thinking academic writings in this way, Molinari argues that we can provide a rationale to explain how they can continue to change. Throughout her chapter, Molinari 
argues that these conceptual tools offer doctoral writing scholars a systematic and critical space for continuing to re-imagine conditions of possibility.

The third chapter in this section, Signe Skov's "Ph.D. by Publication or Monograph Thesis? Supervisors and Candidates Negotiating the Purpose of the Thesis when Choosing Between Formats," examines calls to re-imagine (or resist re-imagining) the format of the doctoral thesis itself. Skov works in Denmark and examines interview data with supervisors and candidates in order to investigate how doctoral candidates legitimize their choice between the monograph thesis or the Ph.D. by publication. Her analysis demonstrates how the doctoral thesis is being re-imagined most often through an instrumental discourse that emphasizes what the thesis does for individuals or institutions rather than what it does for disciplines and knowledge. Within this instrumental discourse, the monograph thesis struggles for recognition as a legitimate format. Alongside these instrumental imaginings, Skov demonstrates that there is also another discourse at work, one that emphasizes contribution to knowledge and disciplines. Skov's chapter can assist doctoral writing researchers in understanding how imaginings of the purpose of doctoral writing shape the ways that doctoral researchers and supervisors argue for or against various thesis formats.

Section Two of this volume, Concepts and Tensions of Doctoral Writing, features three chapters from researchers based in South Africa, Australia, and Canada. Each of these chapters takes up innovative concepts-borders, paths, queer, meta-genre - and uses them to consider how doctoral writing is and is not imagined. These chapters are also linked by an interest in norms that surround doctoral writing and how conventionality and unspoken assumptions work to regulate imaginings of what doctoral writing can be. While many of these chapters examine dominant imaginings of doctoral writing, they also highlight tensions, hidden practices, and possibilities for re-imagining, too.

The first chapter in this section is contributed by Susan van Schalkwyk and Cecilia Jacobs, offering a voice "from the South." In "Borders and Tensions in the Context of Doctoral Writing," van Schalkwyk and Jacobs explore the tensions involved in becoming a researcher, invoking the concept of "border crossing." The authors argue that borders have an important role to play in maintaining disciplinary integrity but that they can also generate significant turbulence for doctoral students who must learn about, and sometimes contest, established disciplinary practices for knowledge production. Building on work in the field of new literacy studies and more recent academic literacies research, the authors argue that collaborative approaches to supervision and the adoption of a cohort model, both of which foster a social practices approach to learning, might facilitate border crossing while alleviating sites 
of tension. Drawing on experiences from South Africa, van Schalkwyk and Jacobs offer more collectivist imaginings of supervision pedagogies for doctoral writing.

Steven Thurlow's "Queer Path-making: Expressing or Suppressing Creativity in Arts Doctoral Writing" is the second chapter in this section. Thurlow explores how doctoral writers in a faculty of arts at an Australian university engage with the notion of creativity, both in relation to what it is, or might be, and where it may be found. He traces the diverse and changing perceptions of creativity held by three multilingual doctoral writers throughout their respective doctoral experiences. Thurlow extends an emerging body of work that has drawn on queer concepts to re-imagine doctoral writing (Burford, 20I7a; Weatherall, 2019) via his use of Sara Ahmed's queer conceptual work on orientation/disorientation (2006) and path-making (2019). Thurlow considers both the well-worn path of "standard" doctoral writing and how students make judgments as to whether they can forge their own unique trail of textual creativity. As Thurlow notes, deviation from the "known path" poses risks, and these are risks students may be unwilling to take. However, Thurlow powerfully documents small moments of creativity and departure from thesis writing conventions. For Thurlow, the queer path remains illuminated, even if it is unfollowed.

The final chapter in this section also links doctoral writing imaginings with a concept, in this case, meta-genre. Sara Doody's chapter "Meta-Generic Imaginings: Using Meta-Genre to Explore Imaginings of Doctoral Writing in Interdisciplinary Life Sciences," explores how doctoral writing is currently imagined in interdisciplinary life sciences (e.g., biophysics, computational biology) doctoral programs in Canada and aims to present avenues for how writing might be re-imagined in these contexts. Conceptualizing writing from a rhetorical genre theory perspective, which views writing as social and situated action, Doody explores meta-genres that dictate how writing is imagined, talked about, conventionalized, experienced, and enacted in interdisciplinary doctoral programs. Doody draws on Giltrow (2002) who has defined meta-genres as "situated language about situated language" (p. 190) and has argued that these can be understood as "atmospheres of wordings and activities ... surrounding genres" (p. 195). In pointing out hidden contradictions between dominant imaginings of writing and writers' own experiences, Doody's chapter suggests that meta-genre offers potential to facilitate a rethinking of interdisciplinary writing. As a resource that encourages writers to critically reflect on how they are situated and how this impacts writing practices, meta-genre has the potential to be an empowering resource for doctoral writers to peel away writing's arhetorical façade and engage in meaningful rhetorical activity. 
Section Three of this volume is called Re-imagining Doctoral Writers and Their Others. This section features chapters from researchers based in the United States of America, Aotearoa New Zealand, and Bangladesh. Extending the work of scholars such as Tai Peseta (200I), the chapters in this section ask questions about the place of identity and embodiment in doctoral writing. Drawing on various methodologies, including cultural rhetorics, autoethnography, and historical analysis, the chapters in Section Three all conceive of doctoral writing as a site of socio-political struggle. For some authors, this leads to calls for the amplification of voices of doctoral writers who are often marginalized in academia, including Southern and Indigenous scholars. For other authors, this leads to a call for greater recognition of the voices of others involved in the doctoral writing process, including community members and typists.

The first chapter in this section, "Embodiment, Relationality, and Constellation: A Cultural Rhetorics Story of Doctoral Writing," examines cultural rhetorics as a methodological tool for re-imagining doctoral writing. Matthew B. Cox, Elise Dixon, Katie Manthey, Maria Novotny, Rachel Robinson, and Trixie G. Smith offer a series of short vignettes in which they outline the various processes involved in their becoming as doctoral writers. While expectations persist that doctoral researchers are "already ready" as writers, Cox and colleagues destabilise these meanings by sharing stories about learning to become a doctoral writer. At the same time, these vignettes also re-imagine doctoral writing as a practice that is inevitably embodied, experiential, and personal. Across these stories, life events occur, and relationships are formed-both between doctoral writers and with the communities that are being studied. The authors conclude by offering lines of inquiry for future doctoral writing researchers who may wish to take up a cultural rhetorics approach.

David Taufui Mikato Fa'avae's chapter, "Vā and Veitapui as Decolonial Potential: Ongoing Talatalanoa and Re-imagining Doctoral Being and Becoming," also considers how doctoral writing may be linked to socio-political struggle. In this chapter, Fa'avae examines how he navigated his own doctoral journey, highlighting the ways he was able renegotiate disciplinary norms and their associated writing conventions to honor Tongan ideas, language, and practices in his doctoral thesis. Taking up questions about epistemic disobedience in doctoral writing, Fa'avae explains how he used the concepts of $v \bar{a}$ and veitapui to carve out space for himself as a doctoral writer from the Moana-Pacific. In particular, Fa'avae shares how he used doctoral learning and writing to enact fatongia, or an obligation and responsibility to honour and safeguard his cultural knowledges. For Fa'avae, doctoral education is a 
practice that is persistently embedded in colonial relations of knowledge production, and yet writing may still be a tool that Indigenous researchers can use in order to re-claim self-determination.

Questions about the relationship between doctoral writing and decolonization are also taken up in Sharin Shajahan Naomi's chapter, "Writing a Doctoral Thesis in a non-Western Voice." In her chapter, Naomi describes the challenge of invoking a non-Western voice in order to challenge the coloniality of knowledge production as a Bangladeshi international student studying in Australia. By waging epistemic disobedience through performative writing, Naomi describes how she created a space for writing her doctoral thesis with a non-Western voice at the same time as encountering struggles for legitimacy. In this chapter, Naomi unpacks some of the strategies she used to re-imagine doctoral writing against the coloniality of knowledge with the aim of showing that writing otherwise is possible.

The final chapter in this section is about those paragraphs that often live close to the front cover of a doctoral thesis/dissertation: the acknowledgements section. In their chapter, "Decentring the Author/Celebrating the Typist in Doctoral Thesis Acknowledgements," Frances Kelly, Catherine Manathunga, and Machi Sato trace the presentation of an emerging academic self in the acknowledgements sections of theses written by doctoral scholars in Aotearoa New Zealand, Australia, and Japan. Here, they consider ways that acknowledgements, those marginal sections of thesis texts, decenter the individual author as sole producer of knowledge and highlight the situated-ness of writing practices, thereby providing alternative imaginaries for doctoral writing. Unlike the main body of the thesis, which must present a legitimate academic authorial self, the peripheral element of the acknowledgements section reveals affective dimensions and recognizes the involvement of others (people and things) in the research and writing process. Kelly, Manathunga, and Sato argue that analysis of these texts-within-the-thesistext enables a reading "against the grain"-giving insight into who/what else contributes to a thesis and revealing the "entanglements" of academic scholarship and writing (Barad, 2007).

Section Four of this volume, Writing a Re-imagined Doctoral Thesis, features three chapters from researchers based in Australia, the United Kingdom, and Aotearoa New Zealand. Each of these chapters considers how doctoral theses can be re-imagined, whether through the innovations of the visual and performing arts, experimentations with fictional writing, or the onto-epistem-ological openings of new materialisms. These chapters are united in their interest in what happens to doctoral writing when key dimensions of the thesis (e.g., its conclusion or materiality) are re-imagined. 
Louise Ravelli, Sue Starfield, and Brian Paltridge's chapter "Re-imagining Doctoral Writing Through the Visual and Performing Arts," draws on a study that examined 36 Australian doctoral theses to explore the contested space of doctoral writing in the visual and performing arts. With theses that incorporate a creative/performed component, whole new ways of doctoral writing have emerged, including new academic voices; innovative forms of typography, layout, and materiality; and varied relations between the written and creative components. Understanding such diverse texts requires a multi-valent approach to recognise the ways in which doctoral writing has been re-imagined in this context and the ways in which the academy can re-imagine a legitimate space for such academic work. Ravelli and colleagues argue that understanding doctoral writing as a practice of meaning-making potential helps lessen individual and institutional anxiety around such texts and provides productive ways forward for doctoral writing pedagogy for these disciplines, as well as for the academy more broadly. The authors offer key strategies that can be enacted to ensure the re-imagined forms that doctoral writers in the visual and performing arts create are better appreciated and have a more settled place in the academy.

In his chapter "Fictional Writing in Doctoral Theses: The (re)Engagement of Play and Reflexivity,"Will Gibson makes a case for experimenting with fiction in doctoral writing. For Gibson, fiction may be used as a writing process or a product with the power to push against the constraints of institutionalized academic language. Gibson argues that fiction writing can provide doctoral students with different ways to speak about affect, about their relationships with participants, about contradictions and messiness, about uncertainties, and about decision-making. In short, fictional representation provides a way of playing with the doctoral performance, moving from an obsession with showing one's expertise with language to a more open exploration of how language can make certain things knowable. The re-imagining Gibson proposes in his chapter is to experiment with doctoral writing as a process of "thinking through" (i.e., of doing thought) rather than of simply representing thinking.

In the final chapter of this section, "The Curious Predicament of an (un) Comfortable Conclusion: Writing with New Materialisms," Toni Ingram explores the notion of concluding. An academic conclusion often entails answers derived from questions such as "What does all this mean?" and "What do we now know about the topic we did not know before?" While conventionally appealing, these questions become redundant within a feminist new materialist approach, as they are premised on a separation between the knower (researcher) and the known (subject/s). This chapter explores tensions that 
emerge between ontological foundations of research and thesis writing conventions, such as a tidy conclusion. Drawing on Karen Barad's (2007) concepts of onto-epistem-ology and intra-action, Ingram considers how a new materialist ontology reconfigures binary concepts, such as question/answer, research/researcher, and knowing/not knowing. These binary concepts, along with doctoral framings of success and failure, often underpin the conclusions a thesis offers. The chapter ponders some of the questions such a blurring of binaries invites in relation to re-imagining doctoral writing.

The final chapter of the volume aims to draw out key contributions that the authors in this book make to the project of re-imagining doctoral writing, and doctoral writing research.

Together, the chapters in this volume highlight both historical and contemporary imaginings of doctoral writing. By reading across these chapters, doctoral writing scholars can trace dominant writing imaginaries as well as trace ideas about writing, doctoral texts, and doctoral writers that push on the borders of recognition and intelligibility. By drawing together scholarship emerging from various parts of the world and from various approaches to thinking about doctoral writing, perhaps we have multiplied meanings of "doctoral writing" and how it might be imagined. Ultimately, we hope this volume offers resources for researchers and students alike to dream possibilities of doctoral writing otherwise.

\section{Acknowledgements}

We would like to thank Barbara Grant, Anthony Paré, Terry Myers Zawac$\mathrm{ki}$, and the anonymous reviewers who each provided helpful feedback as we developed this chapter.

\section{References}

Ahmed, S. (2006). Queer phenomenology: Orientations, objects, others. Duke University Press.

Ahmed, S. (2019). What's the use? On the uses of use. Duke University Press.

Aitchison, C. (2015). Writing the practice/practise the writing: Writing challenges and pedagogies for creative practice supervisors and researchers. Educational Philosophy and Theory, 47(12), 1291-1303. https://doi.org/10.1080/00131857.2015.1035629

Aitchison, C., \& Guerin, C. (2014). Writing groups, pedagogy, theory and practice: An introduction. In C. Aitchison \& C. Guerin (Eds.), Writing groups for doctoral education and beyond (pp. 3-18). Routledge. https://www.taylorfrancis.com/ chapters/edit/10.4324/9780203498811-9/writing-groups-pedagogy-theory-practice-introduction 
Aitchison, C., Kamler, B., \& Lee, A. (Eds.). (2010). Publishing pedagogies for the doctorate and beyond. Routledge. https://doi.org/10.4324/9780203860960

Aitchison, C., \& Lee, A. (2006). Research writing: Problems and pedagogies. Teaching in Higher Education, 11(3), 265-278. https://doi. org/10.1080/13562510600680574

Aitchison, C., \& Mowbray, S. (2013). Doctoral women: managing emotions, managing doctoral studies. Teaching in Higher Education, 18(8), 859-870. https://doi. org/10.1080/13562517.2013.827642

Aitchison, C., \& Mowbray, S. (2015). Doctoral writing markets: Exploring the grey zone. In T. Bretag (Ed.), Handbook of academic integrity (pp. 287-301). Springer. https://doi.org/10.1007/978-981-287-079-7_39-1

Aitchison, C. \& Paré, A. (2012). Writing as craft and practice in the doctoral curriculum. In A. Lee \& S. Danby (Eds.), Reshaping doctoral education: International approaches and pedagogies (pp.12-25). Routledge. https://www.taylorfrancis.com/ chapters/edit/10.4324/9780203142783-10/writing-craft-practice-doctoral-curriculum-claire-aitchison-anthony-par

Amell, B. (in press). Getting stuck, writing badly, and other curious impressions: Doctoral writing and imposter feelings. In M. Addison, M. Breeze, \& Y. Taylor (Eds.), The Palgrave handbook of 'imposter syndrome' in higher education. Palgrave Macmillan.

Amell, B., \& Badenhorst, C. (2018). Introduction: Play, visual strategies and innovative approaches to graduate student writing development. Discourse and Writing/ Rédactologie, 28, 26-32. https://doi.org/10.31468/cjsdwr.724

Artemeva, N. (2006). Approaches to learning genres: A bibliographic essay. In N. Artemeva \& A. Freedman (Eds.), Rhetorical genre studies and beyond (pp. 9-99). Inkshed Publications.

Artemeva, N. (2011). "An engrained part of my career": The formation of a knowledge worker in the dual space of engineering knowledge and rhetorical process. In D. Starke-Meyerring, A. Paré, N. Artemeva, M. Horne, \& L. Yousoubova (Eds.), Writing in knowledge societies (pp. 321-350). The WAC Clearinghouse; Parlor Press. https://doi.org/10.37514/PER-B.2011.2379.2.16

Badenhorst, C. \& Amell, B. (2019). Inextricable: Doctoral writing, engagement, and creativity. Student Engagement in Higher Education, 2(3), 118-137. https://sehej. raise-network.com/raise/article/view/897

Badenhorst, C. \& Guerin, C. (2016). Post/graduate research literacies and writing pedagogies. In C. Badenhorst \& C. Guerin (Eds.), Research literacies and writing pedagogies for masters and doctoral writers (pp.3-28). Brill. https://doi. org/10.1163/9789004304338_002

Badenhorst, C., Moloney, C., Rosales, J., \& Dyer, J. (2012). Graduate research writing: A pedagogy of possibility. LEARNing Landscapes, 6(1), 63-80. https://doi. org/10.36510/learnland.v6i1.576

Badenhorst, C. M., Moloney, C., Rosales, J., Dyer, J. \& Ru, L. (2015). Beyond deficit: Graduate student research-writing pedagogies. Teaching in Higher Education, 20(1), 1-11. https://doi.org/10.1080/13562517.2014.945160 
Bair, C. R., \& Haworth, J. C. (2005). Doctoral student attrition and persistence: A meta-synthesis of research. In J. C. Smart (Ed.), Higher education: Handbook of theory and research (Vol.19, pp. 481-533). Springer, Dordrecht. https://doi. org/10.1007/1-4020-2456-8_11

Barad, K. (2007). Meeting the universe halfway: Quantum physics and the entanglement of matter and meaning. Duke University Press.

Beasy, K., Emery, S., Dyer, L., Coleman, B., Bywaters, D., Garrad, T., Crawford, J., Swarts, K., \& Jahangiri S. (2020) Writing together to foster wellbeing: Doctoral writing groups as spaces of wellbeing. Higher Education Research \& Development, 39(6), 1091-1105. https://doi.org/10.1080/07294360.2020.1713732

Bengtsen, S., \& Barnett, R. (2017). Confronting the dark side of higher education. Journal of Philosophy of Education, 51(1), 114-131. https://doi.org/10.1111/14679752.12190

Berlant, L. (2011). Cruel optimism. Duke University Press.

Boud, D., \& Lee, A. (Eds.). (2009). Changing practices of doctoral education. Routledge. https://doi.org/10.4324/9780203870488

Burford, J. (2014). A meditation on the poetics of doctoral writing. Higher Education Research E Development, 33(6), 1232-1235. https://doi.org/10.1080/07294360.201 4.932040

Burford, J. (2017a). Not writing, and giving 'zero-f**ks' about it: Queer(y)ing doctoral 'failure'. Discourse: Studies in the Cultural Politics of Education, 38(4), 473-484. https://doi.org/10.1080/01596306.2015.1105788

Burford, J. (2017b). Conceptualising doctoral writing as an affective-political practice. International Journal of Doctoral Studies, 12, 17-32. https://doi. org/10.28945/3689

Burford, J. (2018). The trouble with doctoral aspiration now. International Journal of Qualitative Studies in Education, 31(6), 487-503. https://doi.org/10.1080/0951839 8.2017.1422287

Burford, J., Juntrasook, A., Sriprachaya-anunt, W., \& Yeh, L. (2018). A contemplative approach to graduate writing development: Reflections from Thai writing classrooms. Discourse and Writing/Rédactology, 28, 127-148. https://doi. org/10.31468/cjsdwr.599

Carter, S., Guerin, C., \& Aitchison, C. (2020). Doctoral writing: Practices, processes and pleasures. Springer. https://doi.org/10.1007/978-981-15-1808-9

Carter, S., \& Kumar, V. (2017). 'Ignoring me is part of learning': Supervisory feedback on doctoral writing. Innovations in Education and Teaching International, 54(1), 68-75. https://doi.org/10.1080/14703297.2015.1123104

Castelló, M., Pardo, M., Sala-Bubaré, A., \& Suñe-Soler, N. (2017). Why do students consider dropping out of doctoral degrees? Institutional and personal factors. Higher Education, 6(74), 1053-1068. https://doi.org/10.1007/s10734-016-0106-9

Cuthbert, D., \& Molla, T. (2015). The politicization of the $\mathrm{PhD}$ and the employability of doctoral graduates: An Australian case study in a global context. In D. E. Neubauer et al. (Eds.), Technology and workplace skills for the twenty-first century (pp. 95-111). Palgrave Macmillan. https://doi.org/10.1057/9781137491923_8 
Daenekindt, S., \& Huisman, J. (2020). Mapping the scattered field of research on higher education. A correlated topic model of 17,000 articles, 1991-2018. Higher Education, 80, 571-587. https://doi.org/10.1007/s10734-020-00500-x

Das, S. (2012). On two metaphors for pedagogy and creativity in the digital era: Liquid and solid learning. Innovations in Education and Teaching International, 49(2), 183-193. https://doi.org/10.1080/14703297.2012.677594

Davis, G., Wright, H. \& Holley, D. (2016). Write away from it all! The value of running a writing retreat for doctoral students. Practitioner Research in Higher Education, 10(2), 54-66. https://ojs.cumbria.ac.uk/index.php/prhe/article/view/332

Dias, P., Freedman, A., Medway, P., \& Paré, A. (1999). Worlds apart: Acting and writing in academic and workplace contexts. Routledge. https://doi. org/10.4324/9781410602336

Doyle, S., Manathunga, C., Prinsen, G., Tallon, R., \& Cornforth, S. (2018). African international doctoral students in New Zealand: Englishes, doctoral writing and intercultural supervision. Higher Education Research E Development, 37(1), 1-14. https://doi.org/10.1080/07294360.2017.1339182

Dunleavy, P. (2003). Authoring a PhD: How to plan, draft, write and finish a doctoral thesis or dissertation. Palgrave Macmillan.

Fairclough, N. (2003). Analysing discourse: Textual analysis for social research. Routledge.

Fegan, S. (2016). When shutting up brings us together: Several affordances of a scholarly writing group. Journal of Academic Language and Learning, 10(2), A20-A31. https://journal.aall.org.au/index.php/jall/article/view/404

Freedman, A., \& Medway, P. (1994). Locating genre studies: Antecedents and prospects. In A. Freedman \& P. Medway (Eds.), Genre and the New Rhetoric (pp. 2-18). Taylor \& Francis.

Freedman, A., \& Pringle, I. (1980). Epilogue: Reinventing the rhetorical tradition. In A. Freedman \& I. Pringle (Eds.), Reinventing the rhetorical tradition (pp. 173185). L\&S Books.

Giltrow, J. (2002). Meta-genre. In R. Coe, L. Lingard, \& T. Teslenko (Eds.), The rhetoric and ideology of genre: Strategies for stability and change (pp. 187-205). Hampton Press.

Guerin, C., Aitchison, C., \& Carter, S. (2020). Digital and distributed: Learning and teaching doctoral writing through social media. Teaching in Higher Education, 25(2), 238-254. https://doi.org/10.1080/13562517.2018.1557138

Huang, Y. (in press). Doctoral writing for publication. Higher Education Research \& Development. https://doi.org/10.1080/07294360.2020.1789073

Inouye, K.S. \& McAlpine, L. (2017). Developing scholarly identity: Variation in agentive responses to supervisor feedback. Journal of University Teaching $\mathcal{E}^{\circ}$ Learning Practice, 14(2), 1-19. http://ro.uow.edu.au/jutlp/vol14/iss2/3

Kamler, B. (2003). Getting abstracted: Teacher educators as research writers. In T. Townsend (Ed.), Teachers as leaders: Teacher education for a global profession (pp. 1-10). International Council on Education for Teaching. https://dro.deakin.edu. au/view/DU:30005023 
Kamler, B., \& Thomson, P. (2006). Helping doctoral students write: Pedagogies for supervision. Routledge.

Kelly, F. (2017). The idea of the PhD: The doctorate in the twenty-first century imagination. Routledge. https://doi.org/10.4324/9781315707396

Lave, J. \& Wenger, E. (1991). Situated learning: Legitimate peripheral participation. Cambridge University Press.

Lawrence, S., \& Zawacki, T. M. (Eds.). (2018). Re/writing the center: Approaches to supporting graduate students in the writing center. Utah State University Press.

Lea, M. R., \& Street, B. V. (1998). Student writing in higher education: An academic literacies approach. Studies in Higher Education, 23(2), 157-172. https://doi.org/ 10.1080/03075079812331380364

Lee, A., Brennan, M., \& Green, B. (2009). Re-imagining doctoral education: Professional doctorates and beyond. Higher Education Research E Development, 28(3), 275-287. https://doi.org/10.1080/07294360902839883

Lee, A., \& Danby, S. (Eds.). (2012). Reshaping doctoral education: International approaches and pedagogies. Routledge. https://doi.org/10.4324/9780203142783

Lillis, T., Harrington, K., Lea, M. R., \& Mitchell, S. (Eds.). (2015). Working with academic literacies: Case studies towards transformative practice. WAC Clearinghouse; Parlor Press. https://doi.org/10.37514/PER-B.2015.0674

Lillis, T., \& Scott, M. (2007). Defining academic literacies research: Issues of epistemology, ideology and strategy. Journal of Applied Linguistics, 4(1), 5-32.

Lovitts, B. E. (2007). Making the implicit explicit: Creating performance expectations for the dissertation. Stylus Publishing, LLC.

Macfarlane, B. (2012). The higher education research archipelago. Higher Education Research E Development, 31(1), 129-131. https://doi.org/10.1080/07294360.2012. 642846

Maher, D., Seaton, L., McMullen, C., Fitzgerald, T., Otsuji, E., \& Lee, A. (2008). 'Becoming and being writers': The experiences of doctoral students in writing groups. Studies in Continuing Education, 30(3), 263-275. https://doi. org $/ 10.1080 / 01580370802439870$

Manathunga, C., (2019). 'Timescapes' in doctoral education: The politics of temporal equity in higher education. Higher Education Research \& Development, 38(6), 1227-1239, https://doi.org/10.1080/07294360.2019.1629880

McCulloch, A. (2018). The disciplinary status of doctoral education. Higher Education Revierw, 50(2), 86-104. https://www.academia.edu/37819684/The_disciplinary_status_of_doctoral_education

McCulloch, A., \& Thomas, L. (2013). Widening participation to doctoral education and research degrees: A research agenda for an emerging policy issue. Higher Education Research E Development, 32(2), 214-227. https://doi.org/10.1080/07294 360.2012 .662630

Paré, A. (2009). What we know about writing, and why it matters. Compendium 2: Writing, Teaching, and Learning in the University, 2(1). https://ojs.library.dal.ca/ C2/article/view/3720/3408 
Paré, A. (2017). Re-thinking the dissertation and doctoral supervision. Journal for the Study of Education and Development, 4O(3), 407-428. https://doi.org/10.1080/021 03702.2017.1341102

Paré, A. (2019). Re-writing the doctorate: New contexts, identities, and genres. Journal of Second Language Writing, 43, 80-84. https://doi.org/10.1016/j.jslw.2018.08.004

Paré, A., Starke-Meyerring, D., \& McAlpine, L. (2011). Knowledge and identity work in the supervision of doctoral student writing: Shaping rhetorical subjects. In D. Starke-Meyerring, A. Paré, N. Artemeva, M. Horne, \& L. Yousoubova (Eds.), Writing in knowledge societies (pp. 215-235). The WAC Clearinghouse; Parlor Press. https://doi.org/10.37514/PER-B.2011.2379.2.11

Peseta, T. (2001). Imagining a PhD writer's body grappling over pedagogy. In A. Bartlett \& G. Mercer (Eds.), Postgraduate research supervision: Transforming (r)elations (pp. 83-87). Peter Lang.

Ravelli, L., Paltridge, B., \& Starfield S. (Eds.). (2014). Doctoral writing in the creative and performing arts. Libri.

Reither, J. A. (1985). Writing and knowing: Toward redefining the writing process. College English, 47(6), 620-628. https://doi.org/10.2307/377164

Rogoff, B. (1990). Apprenticeship in thinking: Cognitive development in social context. Oxford University Press.

Scevak, J. (2006). Text features and aids in doctoral writing. In C. Denholm \& T. Evans (Eds.), Doctorates downunder: Keys to successful doctoral study (pp.159-164). Acer Press.

Starke-Meyerring, D., Paré, A., Sun, K. Y., \& El-Bezre, N. (2014). Probing normalized institutional discourses about writing: The case of the doctoral thesis. Journal of Academic Language \& Learning, 8(2), A13-A27. https://journal.aall.org. au/index.php/jall/article/view/295

Street, B. (2010). 'Academic literacies approaches to genre'? Revista Brasileira De Linguistica Aplicada, 10(2), 347-361. https://wac.colostate.edu/docs/siget/rbla/ street.pdf

Street, B. (2013). Literacy in theory and practice: Challenges and debates over 50 years. Theory into Practice, 52(suppl. 1), 52-62. https://doi.org/10.1080/00405841.2 013.795442

Swadener, B. B., Peters, L., \& Eversman, K. A. (2015). Enacting feminist alliance principles in a doctoral writing support group. New Directions for Higher Education, 2015(171), 97-106. https://doi.org/10.1002/he.20146

Thomson, P., \& Kamler, B. (2016). Detox your writing: Strategies for doctoral researchers. Routledge. https://doi.org/10.4324/9781315642604

Waite, S. (2017). Teaching queer: Radical possibilities for writing and knowing. University of Pittsburgh Press.

Walker, M., \& Thomson, P. (Eds.). (2010). The Routledge doctoral supervisor's companion: Supporting effective research in education and the social sciences. Routledge. https://doi.org/10.4324/9780203851760

Weatherall, R. (2019). Writing the doctoral thesis differently. Management Learning, 50(1), 100-113. https://doi.org/10.1177/1350507618799867 
Burford, Amell, and Badenhorst

Wegener, C., \& Tanggaard, L. (2013). Supervisor and student co-writing: An apprenticeship perspective. Forum: Qualitative Social Research, 14(3), Article 14. https://doi.org/10.17169/fqs-14.3.2030

Yagelski, R. P. (2011). Writing as a way of being: Writing instruction, nonduality, and the crisis of sustainability. Hampton Press. 


\section{Section One. The Call to Re-imagine Doctoral Writing}





\title{
1 Writerly Aspirations and Doctoral Education: Beyond Neoliberal Orthodoxies
}

\author{
Catherine Mitchell (Taranaki) \\ Unitec Institute of Technology
}

\begin{abstract}
This chapter engages with the imaginings that students bring to the practice of doctoral writing and explores the ways in which neoliberal discourse configures student understandings about the purposes of and possibilities associated with doctoral education. Many scholars identify the dominance of neoliberalism in shaping contemporary higher education practices including within doctoral education. With this in mind, analysis of the data gathered for an empirical study of 15 first-generation students in doctoral education was undertaken to identify how neoliberal conceptions did, or did not, shape their university imaginings and their aspirations for higher degree studies. Within a constellation of hopes, the place of doctoral writing and the figure of the writer itself is identified as being deeply implicated in the formation of doctoral aspirations. It is also suggested that the influence of writers, storytellers, and writerly works informs particular university imaginaries that circulate in discourse and evince different ways of understanding the university beyond neoliberal orthodoxies. As such, this discussion draws attention to the ways in which neither the discursive and imaginative space of doctoral education nor the university itself has been completely captured by neoliberalism. In sum, the findings of this study show that the university and doctoral education is imagined in rich ways and that, in spite of the impacts of neoliberalism, the identity of the scholar remains, for many, bound up with writing and with what it is to be a writer.
\end{abstract}

This chapter engages with the imaginings that students bring to the practice of doctoral writing and explores the ways in which neoliberal discourse configures student understandings about the purposes of and possibilities associated with doctoral education. Many scholars have identified the dominance of neoliberalism in shaping contemporary higher education practices (Olssen \& Peters, 2005; Roberts, 2007; Sims, 2019) including within doctoral educa- 
tion (Bansel, 20II; Cribb \& Gewirtz, 2006). In this piece, I analyze interview and focus group data gathered for an empirical study of 15 first-generation students in doctoral education to identify how neoliberal conceptions did or did not shape their university imaginings and their aspirations for higher degree studies. Within a constellation of hopes, I identify the place of doctoral writing and the figure of the writer itself as being deeply implicated in the formation of doctoral aspirations.

As part of this discussion, I examine who the authorial figure is in the students' imaginings and contemplate how such imaginings may work to shape student aspirations to become doctoral writers. I also suggest that the influence of writers, storytellers, and writerly works informs particular university imaginaries that circulate in discourse and evince different ways of understanding the university beyond neoliberal orthodoxies. From such an understanding, we may find the conceptual resources to think otherwise about the contemporary university and recognise that it has not always been neoliberal nor is neoliberalism the only paradigm presently available to us to understand how social life and social institutions like the university can be formed, experienced, and imagined (Tronto, 20I7). In other words, such work is valuable because it makes clear that the university has not been completely overtaken by neoliberalism, showing us that there is room for imaginings that disrupt, challenge, and unsettle dominant discourses. As a foundation for the argument that extends across the arc of this chapter, I begin by identifying a key premise on which my writing relies, and I introduce the interrelated concepts of imaginings and a social imaginary with reference to the university.

\section{The Importance of University and Doctoral Imaginings}

My argument for the importance of university and doctoral imaginings relies on the following premise: How individuals experience, think about, and imagine different aspects of their lives, including in this case higher education and doctoral study, is meaningful. The ways individuals understand what education offers, the university pathways available to them, and the kind of person one can become through study are notions that are necessarily formed and exist within an individual's imagination. Therefore, exploring students' imaginings is relevant to any exploration of student engagements with higher education and its practices. Ronald Barnett (2013) explained that focusing on how we imagine the university is valid because

a university is both an institution (involving complex sets of processes) and a set of ideas. Both as an institution and as a 
set of ideas, the university may be understood to inhabit spaces (institutional spaces, conceptual and discursive spaces, and imaginative spaces). And both as institution and as a set of ideas the university may be understood as caught in networks (of institutions and communicative systems, and of ideas, visions, aspirations and values). It follows that the university lives (partly) in the imagination, in the ideas, sentiments, values and beliefs that individuals hold in relation to the university. (p. 4I)

In this passage, Barnett (2013) articulated not only how the university can be experienced as an institution but also how it exists within our imaginations. And, as Frances Kelly (20I7) has pointed out, "ideas about the Ph.D. are inextricable from those about the university" (p. 3). Moreover, Lesley Johnson et al. (2000) pointed to the role of "fantasies" about the university and the scholar's life as being valuable in explaining the "deep investments in and attachments to the structures of the $\mathrm{PhD}$ " (p. I36). While I use different terms, I, too, suggest that dreams and imaginings of the university and the university scholar play a key role in shaping our investments in the doctorate.

Indeed, the importance of imagining, or in this case more specifically re-imagining, is reflected in the focus of this edited collection, evidencing that in scholarly work, the imagination can be a key site for creativity, thinking, and, perhaps for our neoliberal times most importantly, thinking differently. Focusing on how the university is imagined can lead to knowledge about the university's perceived role in contemporary social life and the way imaginings and aspirations are bound to individuals' academic identities. As a basis for the discussion that follows, the word imagining is understood to involve an individual "form[ing] a mental image (of something not actually present to the senses)" (Collins English Dictionary, n.d., Definition I). In contrast to the term imagining, which is primarily used to refer to imaginings that belong to individuals, the term social imaginary is used to refer to the imaginings held at a wider social level. As Charles Taylor (2004) maintained, a social imaginary can be understood as "the ways people imagine their social existence, how they fit together with others, how things go on between them and their fellows, the expectations that are normally met, and the deeper normative notions and images that underline these expectations" (p. 23).

\section{Doctoral Education in Context}

In the following, I briefly trace some of the history of doctoral education relevant to the context of this study, that is, at a research university in Aotearoa/ 
New Zealand. Although it is beyond the scope of this chapter to explore the earliest origins of the university more broadly, it is important to recognise the rich traditions of higher learning that exist within many cultures. This is critical to acknowledge, given that writers tend to emphasise the European history of higher education in discussing the origins of the university and the pedagogies employed within it (Bottrell \& Manathunga, 2019). Such a Eurocentric approach makes invisible other educational histories and fails to appreciate the existence of longstanding non-European higher education institutions. Indeed, any discussion of higher education within the Aotearoa/ New Zealand setting needs to begin with recognising the ancient traditions of Māori higher learning within the institution of whare-wānanga. ${ }^{1}$ Although the institution and practices associated with whare-wānanga have increasingly returned to prominence today, the arrival of colonisation in the r8oos meant Māori knowledge systems were displaced and a university system was established that loosely followed the Oxbridge model (Phillips, 2003, as cited in Phillips et al., 20I4).

In this way, the origins of doctoral education in Aotearoa/ New Zealand, as in many places around the globe, can be traced to the European medieval university of the izth century, where the doctorate was a kind of teaching license (Park, 2005). Its most well-known form, the Ph.D., or Doctor of Philosophy, is a relatively recent invention, it being established in tandem with the research university in Germany in the early years of the I9th century ${ }^{2}$ (Middleton, 200I; Park, 2005). The Ph.D. was adopted in the United States near the end of the igth century and arrived in the United Kingdom in the early part of the 2oth century (Middleton, 200I). Despite discussions about the establishment of a Ph.D. degree in Aotearoa/New Zealand as early as I906, it took to the middle of the century before the Ph.D. was permanently introduced in 1948 (Middleton, 200I, 2007). For the majority of the last two centuries, participation in doctoral programmes was typically reserved for in-

1 A whare wānanga, according to Phillips et al. (2014), is "a term made up of two words whare - house and wānanga. As a verb wānanga means to meet and discuss; as a noun wānanga means a seminar or forum, tribal knowledge and learning or instructor or expert" (p. 2-3). Thus whare wānanga is translated as a place of higher learning and refers specifically to "Māori institutions of higher learning" (p. 2-3). In recent times, three publically funded whare wānanga have been established in Aotearoa/New Zealand: Te Whare Wānanga o Raukawa, Te Whare Wānanga o Aotearoa and Te Whare Wānanga o Awanuiarangi. These institutions are recognized as peers of universities and polytechnics and undertake teaching and research from a Māori perspective (Parliamentary Counsel Office, 1989, Section 162).

2 Scholars often point to the establishment of the University of Berlin in 1810 as being central to the development of the Ph.D. (see Middleton, 2001). 
dividuals from more privileged parts of society (Boud \& Lee, 2009), with few students from lower socio-economic backgrounds taking up doctoral studies. In general, the doctoral student of the past was "white, male, young and middle-class" (Petersen, 20I4, p. 823). Moreover, doctoral study throughout most of this time was primarily understood as preparation for an academic career where the receipt of a doctoral qualification would lead to a university position (Neumann \& Tan, 20II).

However, from the mid part of the 2oth century, particularly after World War II ended, higher education expanded ${ }^{3}$ (Barcan, 2013). This growth represented a shift from a focus on educating elite groups in the first part of the 2oth century to the development of a massified system by the new millennium (Leach, 2015). One outcome of the expansion in undergraduate study was that doctoral student numbers began to expand (Brennan \& Naidoo, 2008), leading to a more diverse population of doctoral students (Pearson et al., 20II). In line with international trends, doctoral education in Aotearoa/ New Zealand has grown significantly in the last twenty to thirty years. Ministry of Education figures demonstrate that from 1999 to 2009, enrolments in doctoral programmes more than doubled, rising from 3,447 to 7,409 students and reducing slightly to just over 7,000 doctoral students in 2015 (Ministry of Education, n.d.; Wensvoort, 2010). Amongst other issues, this period of expansion and the growing diversity of students within doctoral education has led to increased concerns about doctoral student progress and anxiety about "quality," particularly in reference to doctoral writing (Burford, 20I7). And, as David Boud and Alison Lee (2009) have suggested, doctoral education nowadays has become a highly scrutinized area of practice within the university (see Introduction, this collection).

\section{Higher Education and the Rise of Neoliberalism}

Neoliberalism is an ideology that has been dominant in the political and economic sphere in western contexts for the past quarter century (McMaster, 2013). It can be described as being "united by three broad beliefs: the benevolence of the free market, minimal state intervention and regulation of the economy and the individual as a rational economic actor" (Saunders, 20Io, p. 45). At its center, neoliberal philosophy suggests that the role of the state in society should be limited in favour of the marketplace because the market is

3 From the mid-1990s the numbers of students enrolled in higher education around the globe more than doubled from 76 million individuals to 179 million by 2009 (Brown, 2013). 
understood as being a more effective means of meeting social needs (McMaster, 20I3). This logic provides the rationale for the redistribution of wealth through taxation and the reduction in public spending to fund welfare, health, and education.

Moreover, from a neoliberal perspective, individuals are viewed as "human capital" and are narrowly and primarily understood in terms of competitive economic self-interest. Michel Foucault (2008) referred to this neoliberal subject as homo economicus. He argued that neoliberal subjectivity is defined by competition and that individuals within this view need to strive to be entrepreneurial, self-investing, and responsible for their own success (Bazzul, 20I6). Simon Marginson and Mark Considine (2000) also argued that neoliberal ideas have led to the re-framing of higher education as a business to be managed like any other. In Aotearoa/New Zealand, as in many other countries, "cultural activities such as education have become appropriated as economic transactions" (Fitzsimons, 2000, p. I4). From this viewpoint, doctoral students are understood as highly trained knowledge workers fit for the professional marketplace. Such a framing aids the repositioning of knowledge-related research activities to be "increasingly driven by commerce and regulated through economic policies and practices” (Bansel, 20II, p. 547).

In the context of a neoliberal agenda that seeks enhanced efficiency, accountability, and competition (Barrow \& Grant, 20I6), universities have established complex audit cultures to ensure the close monitoring of performance outcomes (Bansel, 20II). This heightened focus on performance, informed by a managerial ethos, has been applied across higher education. This includes doctoral programmes and is reflected in the introduction of increased reporting requirements, confirmation processes, and standard timeframes for the achievement of research milestones (Bansel, 20II; Cribb \& Gewirtz, 2006). Given that successful degree completion relies upon the completion of the doctoral thesis, "doctoral writing has emerged as a new problem space for institutional attention and intervention” (Starke-Meyerring et al., 20I4, p. Aı3).

\section{Theoretical Orientation and Study Methodology}

This chapter discusses the findings of a post-structural research study on doctoral education that involved 15 students attending a New Zealand university. A post-structural perspective recognises the importance of language and discourse as a primary determinant of how we understand ourselves, others, and our world. Within this perspective, language is understood as lacking fixed meanings and as being used in particular ways and with particular meanings by dominant social groups. In terms of the significance of language, how- 
ever, there is no automatic or direct pathway to understanding, as language meanings are shifting, highly contextual, and multiple (Beasley, I999; Crowe, I998). Therefore, post-structural researchers seek to avoid essentialist generalisations of students' accounts and experiences and seek instead to focus on the local, subjective, partial, or even contradictory (Giddings \& Grant, 2009; Hardy, 20I2). The work of a post-structural researcher involves close readings of text typically in intensive ways to identify assumptions and locate contradictions and conflicts.

The research participants in this study were first-generation students; that is, they were individuals who were members of the first-generation in a family to attend university and who were at the time either completing, or had recently completed, a Ph.D. or Ed.D. at a research-intensive university. All students were undertaking work in the discipline of education or were undertaking interdisciplinary work with an education focus. The participant group included I3 women and 2 men from a variety of cultures including students from African, Asian, Pākehā (New Zealand European), Māori, and Pasifika backgrounds. Permission to carry out the research was obtained via the University of Auckland Research Ethics Committee. Participants engaged in semi-structured, hour-long interviews and were invited to join a focus group to discuss their experiences of higher education and share images or artefacts that represented the university to them. Both the interviews and focus group sessions were recorded and transcribed for analysis. Students were given pseudonyms unless they wished to have their own first names used within the study.

The texts gathered in this study, including interview and focus group transcripts and images, were subject to careful reading and deconstructive interpretive practices. A number of key neoliberal concepts were drawn from relevant literature to enable an analysis of students' accounts and to identify the presence of neoliberal discourse. These concepts include the notion of competitive economic self-interest as guiding the actions of rational human actors (Bansel, 20Ir; Louth \& Potter, 20I7; Marginson \& Considine, 2000), self-investment (Bazzul, 2016; Fitzsimons, 2000), responsibility or self-management (Louth \& Potter, 20I7), and the centrality of the marketplace to all aspects of life (McMaster, 2013; Saunders, 2010). While these concepts are commonly seen as central to neoliberal discourse, it is necessary to acknowledge that neoliberalism is not a fixed group of beliefs and ideas but instead is "a complex, often incoherent, unstable and even contradictory set of practices that are organized around a certain imagination of the 'market"' (Shamir, 2008, p. 3). It is salutary here to remember that the different, and sometimes loose, ways that neoliberalism is articulated and constructed (Ball, 20I2) does not mean its power should be underestimated. As Patrick Fitzsimons (2000) 
maintained, the discourse of neoliberalism needs to be understood as being not just one among many, but "as a master discourse, or what Lyotard (1984) calls a 'metanarrative' to which all developments in the policy sphere must adhere" (p. I4).

\section{Locating Neoliberal Imaginings}

It is clear that those who pursue doctoral study can be characterized as individuals who are willing to make major investments in themselves through earning a doctoral qualification, something that requires intensive study to complete (in the New Zealand context, students usually take three to four years to earn the degree if enrolled fulltime). This aspect of doctoral study alone means neoliberal imperatives can easily be ascribed to students' motivations, given that doctoral education requires individuals be self-managing and prepared to invest significant time and effort in complex research projects. However, this fact must be read in context because the willingness of individuals to make such investments has always been a necessary element in doctoral work and is something that obviously predates the rise of neoliberalism. This means that it is crucial to look more deeply into how the students think about the purposes and the rewards of doctoral study.

Analysis of the data in this research identifies an array of neoliberal conceptions within the students' accounts. In this study, the willingness to invest in doctoral education was often strongly tied to employment goals with the aspiration to gain a "good job," particularly a good academic job. This aspiration was typically identified as one of the first students mentioned amongst a range of hoped for outcomes, with two thirds (IO/15) of the participants identifying their aspirations to take up academic roles on the completion of their doctoral programmes. When the number of students five years from retirement was removed from the wider group, the proportion expressing their post-doctoral aspirations for academic work grew to Io out of I2 participants, representing over 80 percent of the students in this small-scale study.

The students spoke about their academic aspirations in different ways but regularly described employment in the university as "good work" that was well remunerated. As one international student stated, "being doctor somebody in society means that ... in relation to finances, you are going to secure a good job, you are going to be able to get money" (Marie). Another student identified an academic role as a "good job" in terms of economic rewards and where a "person was respected and valued" (Linda). Such comments clearly connected doctoral study directly with individual economic and social benefits. In Linda's case, the impetus to invest in Ph.D. study was tied to neoliberal 
imperatives in a further way, in terms of the international higher education marketplace. She was, as she described, "forced to do that [doctoral study]," as there was a strong drive in her Asian setting to "upgrade the profile of the university." As such, Linda's comments could be read as speaking to an educational context where there is significant competition between universities, leading to major pressure on institutions to meet the demands of the market through staff possessing doctoral degrees and achieving high levels of research publications (see also, Introduction, this collection). Such competition is fuelled by intensive audit regimes put in place to enable, amongst other things, the ranking of universities across the globe in the drive for status and funding (Lynch, 20I5).

Notably, the students talked about their academic aspirations not only in terms of individual rewards but also in terms of their desire to contribute to the lives of others in their wider families and communities (Fa'avae, Chapter 8 this collection, also explores these desires). This was particularly apparent in the accounts of the students from Indigenous cultures. As one student from Africa commented, "I am looking at supporting him [my father] in whichever way I can. . . and establishing one or two projects where my family can work with me" (Dante). Here, Dante spoke about his hopes to help his father and family based on his doctoral education. He also described "helping the people who are vulnerable ... and the children with disabilities in this case ... it will be quite good support ... for society" (Dante). In this account, doctoral education was imagined in ways that go beyond neoliberal notions of self-interest and competition, and Dante highlighted the ways the doctoral project can provide a basis for the sharing of economic resources and knowledge, revealing a collectivist rather than a solely individualist orientation.

Another student in this study, Sue, also reflected on her early understandings of higher education and how neoliberal constructs were used by teachers to frame these understandings. She remembered one pivotal event in her final years of high school:

They took us to an engineering firm and they did this thing where they took a page from a magazine, and they said, okay, so this outfit costs whatever. If you worked at McDonalds, it would take you three weeks to earn this money, if you did this job, it would take you one week, ... if you were an engineer, you could make this by Monday morning, and then I was like, I'm going to university.

This articulation of the purpose and value of a university education relies on the understanding of higher education based on money and purchasing pow- 
er and was clearly presented in "predominantly economic terms characterized in our current times by neoliberal ideology and consumer values" (Sellar \& Gale, 20I2, p. I05). Although her teachers' words ignited Sue's interest in higher study, she felt these messages about university education were simplistic and misleading because higher study, for her, did not automatically equate to earning large amounts of money. While she rejected such narrowly defined neoliberal framings of university study, the connections between higher education and her ability to earn a good living nevertheless remained significant for Sue. She described how her aspirations for doctoral study had shifted over time; having initially desired to become an academic, Sue was now interested in other kinds of professional work. For her, the role of an academic, in contrast to some of the other students in this study, was "no longer appealing ... because of the lack of employment stability and low pay." Sue's views can be seen as identifying the importance of economic returns for her doctoral aspirations and thus appear to be consistent with neoliberal values.

The drive to be excellent and achieve at a high level was also apparent across students' accounts. This may be somewhat unsurprising, given that students need to be highly motivated and academically successful in order to access doctoral programmes in the first place. Nonetheless, it was notable how often in the accounts students mentioned that they were "high achievers," "top students," or "perfectionists." Linda, for example, reflecting on her doctoral studies, connected her drive for success with an implied reference to others; she described how she wanted to achieve something beyond some kind of average or medium level, something that was necessarily identified in relation to the work of other students. As she said, "I have very high expectations. Really, I can't settle for, like, a mediocre performance." These comments underscored her focus on high achievement and, to some extent, her competitive orientation. In this way, Linda's comments may be construed as evidencing neoliberal competitive values, though this drive for achievement was not strongly framed in market terms through any specific reference to consumerism or to particular economic goals beyond a general goal of having a good level of income.

\section{Locating the Presence of the Writer and "Ivory Tower" Imaginings}

It was also notable that students spoke of their investments in the doctorate and their aspirations tied to their ongoing university studies in a variety of ways that do not easily conform to neoliberal perspectives. Katie, similar to Linda, described undertaking doctoral studies as a necessary work require- 
ment for her to remain in her university position. Yet, she identified her aspirations for study largely outside of employment goals, reflecting on her early imaginings of the university and some of the famous writers who inspired her. She discussed her love of storytelling and her experience of reading the works of C. S. Lewis and J. R. R. Tolkien, two University of Oxford professors, at intermediate or high school. In her mind, these well-known figures of English literature embodied the university:

I read about how C. S. Lewis and Tolkien used to go to this club, and they would talk together, and I loved that idea of these two professors getting together with their pipes.... I had this image in my mind ... like the hobbits all getting together with them and blowing smoke rings like Gandalf.

Her reflection invokes a fantasy world where writer-academics mingle with their characters and harkens to a realm of old-fashioned men's clubs and privilege from times long past. Her comments also accord with the notion that being an academic within the university "means also being a writer" (Grant \& Knowles, 2000, p. 6). As Pat Thomson and Barbara Kamler (20I2) maintained "writing is integral to the identity of a 'scholar" (p. I5). In simple terms, scholars are required to write and to produce certain types of written texts. Thus, if one seeks to become a scholar or academic by an alternative name, one needs to take up "the writing project as means of identifying" oneself with a scholarly identity (Thomson \& Kamler, 20I2, p. 15). This writerly identity, so identifiable in Katie's words, appears to be an especially significant impetus for taking up doctoral work for some in this study.

Katie's recalled imagining, with her identification of two figures enjoying conversation in a convivial environment, also fits with popular perceptions of academics and their comfortable lifestyles. As evidenced by her comments, the notion of a rather genteel scholarly lifestyle continues to circulate in discourse (Brew, 200I) despite the fact that many who work within the university understand academic roles as increasingly "being heavy in workload and unsatisfactory in content" (Tight, 20I0, p. I09). Moreover, Katie's account, through its reference to these famous writers and Oxford lecturers in the early 20 th century, speaks to a particular kind of academic within the historic university. Allison Kelaher Young (2005) described this academic figure as being imagined as an "older, distinguished white gentlemen-scholar, the liberal intellectual who sits in the Ivory Tower contemplating questions about which the majority of people could care less" (p. 97). Indeed, Katie's imaginings work to bind the figure of the writer-scholar together with an imaginary of the university as an exclusive ivory tower. A feminist analysis of her shared 
imagining might also emphasise the elite nature of this university and draw attention to the way in which Katie imagined a place of middle-class White men within this ivory tower university setting-a place that did not have much space for working-class women like herself. Nonetheless, Katie spoke of this imagining as being inspiring and through her reading, she was able to imagine herself into this site of elite male privilege.

The significance of the place of writers further emerged in her account when Katie discussed her engagement with the idea of the university as a place for writers. She said,

As I got older, I became aware that to be a writer there were different things that you had to go through to learn how to write and where the appropriate [emphasis added] places to learn how to write might be.... So, Tolkien and Lewis lived in a university in my mind.

In her words, the university is a kind of "special" place, one that allows someone to become a writer in the company of others with similar interests and commitments. In this view, it is possible to find some cosiness in her account in which the university is a place where the life of the mind may be nurtured and appreciated. Moreover, she later commented on her aspirations for her doctoral thesis and spoke of her goal to prepare a writerly text that would create a powerful affective response in its readers. It was Katie's hope that her thesis would be "something stunning that will capture the hearts of people and move them." Again, her words indicate that writerly aspirations were important in shaping her orientation to her doctoral work, though in ways that do not seem to emphasise competition, economic interests, or employment.

The place of literary works and storytelling in shaping early university imaginings can also be seen in other students' accounts. Kat, for example, described being so inspired by the story of The Lord of the Rings that she decided at the age of eight or nine that she was going to become a film director so she could create filmic stories. In her mind, a way to achieve this was by undertaking university study, and she said that this imagining of a desired future self and the role of the university in helping her achieve it continued to inspire her subject choices and university pathway. This brief account reveals the way Kat's university imaginings seemed to contribute to her academic journey-making, highlighting the significance of well-known literary or cultural narratives in shaping her university and, to some extent, her doctoral education pathway.

A further link to the connections between higher study and writing was identified by a Māori student. Arohanui shared information about her tā 
moko (tattoo), which incorporated a symbol of a writing instrument mixed with Māori motifs to represent her conception of the university as a key site for gaining access to knowledge. Arohanui spoke of her tattoo as representing the knowledge that comes from the heavens and her tipuna (ancestors), locating this knowledge firmly within her whānau (family/extended family) relations. As she explained, knowledge is symbolized within her tā moko in the form of a traditional writing tool, something that is held in one's hands. Arohanui also identified how her tā moko speaks to the importance of using knowledge with responsibility, kindness, and love in the context of deep social bonds. In this way, a symbol of writing paired with Māori motifs locates the importance of family, culture, and writing at the heart of scholarly endeavours. Furthermore, it seems possible to discern in her account a specific connection to the "ivory tower" university imaginary in the way that her tà moko included a writing instrument used over the centuries and long associated with the images of scholars and "men of letters" within a European intellectual tradition.

Although it is outside the scope of this chapter to explore Māori orientations to the western university in depth, Arohanui's sharing of her tā moko revealed the deep significance of culture in shaping her views of the university. Her educational imaginings connected both Māori and Pākehā (non-indigenous New Zealanders) notions of the university and demonstrated how Māori can rework and incorporate Pākehā knowledge systems within a Māori worldview. Indeed, it may be possible to see such framings as evidence of the potential for new university imaginaries to emerge, in this case, those strongly grounded in indigenous knowledge and practices. How such an imaginary may sit alongside, unsettle, or disrupt other more established university imaginaries, such as a neoliberal imaginary, remains to be seen. However, such an imaginary arguably would, nonetheless, present a highly fertile space for the development of new understandings about the role and purposes of the university within the local context (see also Fa'avae, Chapter 8 , this collection).

\section{Concluding Points}

In my discussion, I have pointed to a number of university imaginaries, including a neoliberal imaginary, an ivory tower university imaginary, and, possibly, an emerging imaginary rooted in Māori notions of the university. By exploring each of these imaginaries in turn, I have found that, although it may seem each imaginary is fully distinct and separable from the others, in fact the imaginaries can operate together in complex and shifting ways. Indeed, the 
university imaginaries discussed here are likely to "wash" together and lead to individuals possessing a mix of different investments in, and understandings of, higher study. This can be seen in the multiple ways students identified their doctoral aspirations and university imaginings, sometimes with obvious reference to neoliberal constructs and other times not. A tight combination of different ideas of the university were also identifiable in students' accounts. This is particularly apparent, for instance, in the way Arohanui invoked what could be framed as an emerging Māori imaginary while at the same time employing concepts associated with the imaginary of the university as an "ivory tower" as symbolized through the image of a traditional writing instrument.

Overall, my readings of the accounts of the individuals in this study demonstrate that, alongside a neoliberal imaginary, other social imaginaries of the university (such as the university as ivory tower) continue to circulate. This accords with Ruth Barcan's (2013) view that our understandings of the university should rightly be seen as palimpsestic, in that there is a layering of different imaginaries operating at the same time and where earlier values, notions, and ideals are not fully erased despite the dominant and most easily identifiable presence of neoliberal discourses. Recognising that there are different university imaginaries at play is significant, as imaginaries are discursive structures and, as such, are imbued with power, offering a range of conceptual and identity resources from which one can draw to think, speak, and argue. Such a recognition is valuable in that it reminds us that the university has not always been neoliberal and that the university can be imagined and organized in ways that exceed neoliberal orthodoxies. Moreover, within this varied space of university imaginings, it is possible to apprehend the significance of writing, writers, and indeed, storytelling in influencing student desire to take up doctoral education and to become doctoral writers. In sum, the analysis of the students' accounts in this chapter reveal how the university and doctoral education is understood and imagined in rich ways and demonstrates that in spite of the impacts of neoliberalism "the identity of the scholar and the practice of scholarship" remain "tangled in writing" (Thomson \& Kamler, 20I2, p. 18).

\section{References}

Abbott, P., Wallace, C., \& Tyler, M. (2005). An introduction to sociology: Feminist perspectives (3rd ed.). Routledge. https://doi.org/10.4324/9780203489949

Ball, S. J. (2012). Performativity, commodification and commitment: An I-spy guide to the neoliberal university. British Journal of Educational Studies, 60(1), 17-28. https://doi.org/10.1080/00071005.2011.650940 
Bansel, P. (2011). Becoming academic: A reflection on doctoral candidacy. Studies in Higher Education, 36(5), 543-556. https://doi.org/10.1080/03075079.2011.594592

Barcan, R. (2013). Academic life and labour in the new university: Hope and other choices. Ashgate Publishing. https://doi.org/10.4324/9781315565460

Barnett, R. (2013). Imagining the university. Routledge. https://doi. org/10.4324/9780203072103

Barrow, M., \& Grant, B. M. (2016). Changing mechanisms of governmentality? Academic development in New Zealand and student evaluations of teaching. Higher Education: The International Journal of Higher Education Research, 72(5), 589-601. https://doi.org/10.1007/s10734-015-9965-8

Bazzul, J. (2016). Ethics in science education: How subjectivity matters. Springer. https://doi.org/10.1007/978-3-319-39132-8

Beasley, C. (1999). What is feminism? An introduction to feminist theory. Sage.

Bottrell, D., \& Manathunga, C. (2019). Shedding light on the cracks in neoliberal universities. In D. Bottrell \& C. Manathunga (Eds.), Resisting neoliberalism in higher education: Vol. 1 Seeing through the cracks (pp. 1-34). Palgrave Macmillan.

Boud, D., \& Lee, A. (2009). Introduction. In D. Boud \& A. Lee (Eds.), Changing practices of doctoral education (pp. 1-9). Routledge. https:/www.taylorfrancis.com/ chapters/edit/10.4324/9780203870488-6/introduction-david-boud-alison-lee

Brennan, J., \& Naidoo, R. (2008). Higher education and the achievement (and/or prevention) of equity and social justice. Higher Education, 56(3), 287-302. https:// doi.org/10.1007/s10734-008-9127-3

Brew, A. (2001). The nature of research: Inquiry in academic contexts. RoutledgeFalmer. https://doi.org/10.4324/9780203461549

Brown, P. (2013). Education, opportunity and the prospects for social mobility. British Journal of Sociology of Education, 34(5-6), 678-700. https://doi.org/10.1080 /01425692.2013.816036

Burford, J. (2017). Conceptualising doctoral writing as an affective-political practice. International Journal of Doctoral Studies, 12, 17-32. https://doi.org/10.28945/3689

Collins English Dictionary. (n.d.) Imagining. (2016). In Dictionary.com. Retrieved April 26, 2021, from http://www.dictionary.com/browse/imagining

Cribb, A., \& Gewirtz, S. (2006). Doctoral student supervision in a managerial climate. International Studies in Sociology of Education, 16(3), 223-236. https://doi. org/10.1080/09620210601037787

Crowe, M. (1998). The power of the word: Some post-structural considerations of qualitative approaches in nursing research. Journal of Advanced Nursing, 28(2), 339-344. https://doi.org/10.1046/j.1365-2648.1998.00780.x

Fitzsimons, P. (2000). Neo-liberalism and 'social capital': Reinventing community [Conference presentation]. New Zealand Association for Research in Education (NZARE) AREA Conference, New Orleans, LA, United States. http://www. amat.org.nz/Neoliberalism.pdf

Foucault, M. (2008). The birth of biopolitics: Lectures at the College de France, 19781979 (M. Senellart, F. Ewald, A. Fontana, \& A. I. Davidson, Eds.; G. Burchell, Trans.). Palgrave Macmillan. https://doi.org/10.1057/9780230594180 
Giddings, L. S., \& Grant, B. M. (2009). From rigour to trustworthiness: Validating mixed methods. In S. Andrew \& E. J. Halcomb (Eds.), Mixed methods research for nursing and the health sciences (pp. 119-134). Wiley-Blackwell. https://doi. org/10.1002/9781444316490.ch7

Grant, B., \& Knowles, S. (2000). Flights of imagination: Academic women be(com) ing writers. International Journal for Academic Development, 5(1), 6-19. https://doi. org/10.1080/136014400410060

Hardy, J. (2012). Narrative theory versus truth: A poststructuralist reading in environmental education. The International Journal of Interdisciplinary Social Sciences, 6(8), 167-173. https://doi.org/10.18848/1833-1882/CGP/v06i08/52135

Johnson, L., Lee, A., \& Green, B. (2000). The PhD and the autonomous self: Gender, rationality and postgraduate pedagogy. Studies in Higher Education, 25(2), 135-147. https://doi.org/10.1080/713696141

Kelaher Young, A. J. (2005). Should I stay or should I go? Lesbian professors in popular culture. In S. Edgerton, G. Holm, T. Daspit, \& P. Farber (Eds.), Imagining the academy: Higher education and popular culture (pp. 197-216). RoutledgeFalmer.

Kelly, F. (2017). The idea of the PhD: The doctorate in the twenty-first century imagination. Routledge. https://doi.org/10.4324/9781315707396

Leach, L. (2015). Widening participation in Aotearoa New Zealand tertiary education since 2000. In M. Shah, A. Bennett, \& E. Southgate (Eds.), Widening higher education participation: A global perspective (pp. 35-48). Elsevier Science. https:// doi.org/10.1016/B978-0-08-100213-1.00003-2

Louth, J., \& Potter, M. (2017). The production of neoliberal subjectivities: Constellations of domination and resistance. In J. Louth \& M. Potter (Eds.), Edges of identity: The production of neoliberal subjectivities (pp.1-24). University of Chester.

Lynch, K. (2015). Control by numbers: New managerialism and ranking in higher education. Critical Studies in Education, 56(2),190-207. https://doi.org/10.1080/1 7508487.2014.949811

Marginson, S., \& Considine, M. (2000). The enterprise university: Power, governance and reinvention in Australia. Cambridge University Press.

McMaster, C. (2013). Working the 'shady spaces': Resisting neoliberal hegemony in New Zealand education. Policy Futures in Education, 11(5), 523-531. https://doi. org/10.2304/pfie.2013.11.5.523

Middleton, S. (2001). Educating researchers: Nerw Zealand education PhDs, 1948-1998. New Zealand Association for Research in Education (NZARE)-Te Hautaka Mātai Mātauranga o Aotearoa.

Middleton, S. (2007). The place of theory: Locating the New Zealand 'education' Ph.D. experience, 1948-1998. British Journal of Sociology of Education, 28(1), 69-87. https://doi.org/10.1080/01425690600996691

Ministry of Education. (n.d.). Tertiary participation. New Zealand Government. Retrieved April 26, 2021, from https://www.educationcounts.govt.nz/statistics/ tertiary-education/participation 
Neumann, R., \& Tan, K. K. (2011). From PhD to initial employment: The doctorate in a knowledge economy. Studies in Higher Education, 36(5), 601-614. https://doi. org/10.1080/03075079.2011.594596

Olssen, M., \& Peters, M. A. (2005). Neoliberalism, higher education and the knowledge economy: From the free market to knowledge capitalism. Journal of Education Policy, 20(3), 313-345. https://doi.org/10.1080/02680930500108718

Park, C. (2005). New Variant PhD: The changing nature of the doctorate in the UK. Journal of Higher Education Policy \& Management, 27(2), 189-207. https://doi. org/10.1080/13600800500120068

Parliamentary Counsel Office. (1989). Education Act 1989. New Zealand Government. https://www.legislation.govt.nz/act/public/1989/0080/latest/ DLM175959.html

Pearson, M., Cumming, J., Evans, T., Macauley, P., \& Ryland, K. (2011). How shall we know them? Capturing the diversity of difference in Australian doctoral candidates and their experiences. Studies in Higher Education, 36(5), 527-542. https:// doi.org/10.1080/03075079.2011.594591

Petersen, E. B. (2014). Re-signifying subjectivity? A narrative exploration of 'non-traditional' doctoral students' lived experience of subject formation through two Australian cases. Studies in Higher Education, 39(5), 823-834. https://doi.org/ 10.1080/03075079.2012.745337

Phillips, H., Cram, F., Sauni, P., \& Tuagalu, C. (2014). Whaia i te maramatangaseek knowledge. In F. Cram, H. Phillips, P. Sauni \& C. Tuagalu (Eds.), Mãori and Pasifika higher education horizons (pp.1-18). Emerald Group Publishing. https://doi.org/10.1108/S1479-364420140000015008

Roberts, P. (2007). Neoliberalism, Performativity and Research. International Review of Education, 53, 349-365. https://doi.org/10.1007/s11159-007-9049-9

Saunders, D. (2010). Neoliberal ideology and public higher education in the US. Journal for Critical Education Policy Studies, 8(1), 42-77. http://www.jceps.com/ archives $/ 626$

Sellar, S., \& Gale, T. (2012). Aspiration and education: Toward new terms of engagement for marginalized students. In B. J. McMahon \& J. P. Portelli (Eds.), Student engagement in urban schools: Beyond neoliberal discourses (pp. 91-109). Information Age Publishing.

Shamir, R. (2008). The age of responsibilization: On market-embedded morality. Economy and Society, 37(1), 1-19. https://doi.org/10.1080/03085140701760833

Sims, M. (2019). Neoliberalism and new public management in an Australian university. Australian Universities' Review, 61(1), 22-30. https://eric.ed.gov /?id=EJ1206807

Starke-Meyerring, D., Paré, A., Sun, K. Y., \& El-Bezre, N. (2014). Probing normalized institutional discourses about writing: The case of the doctoral thesis. Journal of Academic Language छ Learning, 8(2), A13-A27. https://journal.aall.org. au/index.php/jall/article/view/295

Taylor, C. (2004). Modern social imaginaries. Duke University Press. https://doi. org/10.1215/9780822385806 
Thomson, P., \& Kamler, B. (2012). The writer. In P. Thomson \& B. Kamler (Eds.), Writing for peer reviewed journals: Strategies for getting published (pp.13-28). Routledge.

Tight, M. (2010). The golden age of academe: Myth or memory? British Journal of Educational Studies, 58(1), 105-116. https://doi.org/10.1080/00071000903516502

Tronto, J. (2017). There is an alternative: Homines curans and the limits of neoliberalism. International Journal of Care and Caring, 1(1), 27-43. https://doi.org/10.1332/ $239788217 X 14866281687583$

Wensvoort, M. (2010). 2009 Tertiary education enrolments. Ministry of Education. https://www.educationcounts.govt.nz/publications/80898/75361 


\title{
Re-imagining Doctoral Writings as Emergent Open Systems
}

\author{
Julia Molinari \\ The University of Nottingham
}

\begin{abstract}
Drawing on critical realism, complexity theory, and emergence, this chapter supports the call to re-imagine doctoral writing by arguing that academic writing in general is a complex open and emergent social system that can change. Several reasons to re-imagine doctoral writing are discussed. The first reason is that academic writings ${ }^{\mathrm{I}}$ already exhibit considerable diversity. This suggests that the conditions of possibility for re-imagining them are already in place and provide a conceptual space from which to further imagine. Second, there are epistemic reasons for re-thinking how we write, as evidenced by research on socio-semiotics. Several examples of doctoral writers who have re-imagined their writing for epistemic reasons are given. To explain how change in social phenomena is possible and how it can continue to be justified, I draw on the theory of complex permeable open systems. These systems are emergent and, as such, allow us to think of social phenomena, such as writing, as non-reductive organic unities whose characteristics emerge from but cannot be reduced to any single constituent feature (such as grammar or lexis). By re-thinking academic writings in this way, we can provide a rationale to explain how they can continue to change. The chapter concludes by sharing the work of scholars engaged in re-imagining doctoral writings. The significance for writing studies is that critical realism offers a systematic and critical space within which to explain change in social phenomena and provides a theoretical foundation for continuing to re-imagine conditions of possibility.
\end{abstract}

1 I intermittently use the plural — academic or doctoral writings — to signal or remind the reader that academic texts are varied. For example, there are traditional Ph.D. "big book" theses, but there are also $\mathrm{Ph} . \mathrm{D}$. theses by publication, which include several journal articles; art-based doctorates, which require an exegesis to critically explain a work of art; Ed.D. theses, which, in the UK, are typically shorter than the Ph.D. thesis; and several multimodal formats. Where I use the singular, I am simply reverting to standard usage. 
Imagination plays a crucial role in the making of pivotal educational features and phenomena, such as knowledge, inquiry, choice and deliberation, critical agency, meaning creation, forecasting, and, importantly, openness of possibilities.

- d'Agnese, 20I7, p. 444

The question of whether doctoral writing ought to be re-imagined is a core concern that is addressed by this volume. To be sure, there are compelling reasons to resist the changes that any re-imagining of doctoral writing practices might entail. These include the perception that there is no need to change what already seems to be fit-for-purpose or that the risks of challenging the status quo outweigh the benefits. Yet, despite the reasons to resist change, bodies of literature on academic writing suggest an openness to re-imagining what is possible. These literatures range from scholarly blog entries (Mewburn, 2020; Thomson, 20I5), to newspaper articles (Wolff, 2007), to systematic studies on the "conditions of possibility" of Ph.D.s (Fransman, 20I2; Paré, 20I8), all of which have investigated whether doctoral writings are "fit-for-purpose" (Mewburn, 2020; Paré, 2018). Together, these accounts have offered compelling reasons to challenge traditional practices and to extend how academic writing is "habitually understood," as the editors of this collection are encouraging us to do.

In this chapter, I support the call to re-imagine doctoral writings and do so by mobilising the sociological and philosophical notion of "open systems" (Collier, I994), a notion that draws on complexity theory (Parnell, 20I2) and critical realism (Sawyer, 200I). I begin by outlining two reasons why doctoral writings need to be re-imagined: The first is that there are several ways for academic writing to be "academic;" the second is that re-imagining how we write may broaden how we understand and represent knowledge. I then offer several examples of re-imagined doctoral writings and explain in what sense they are all academic and how they broaden the possibilities for epistemic representation. Next, I move on to explain that this re-imagining becomes possible when academic writings are conceptualized as a complex open system. The significance of this understanding is that open systems are permeable, meaning they are subject to change, yet also recognisable and stable (which is why they remain systems). I conclude with the hope that this theorisation can contribute to and support current and future re-imaginings of doctoral writing.

\section{Reasons to Re-imagine: Family Resemblance and Epistemic Representation}

Doctoral writings are part of a broader academic writing landscape. In this 
sense, they are one of several academic genres, understood here as "conventionalised ways of acting and interacting" (Hamilton \& Pitt, 2009, p. 63) that exhibit regularities and shared understandings of how language is used (Devitt, I996).

There are several interrelated reasons for re-imagining doctoral writings beyond existing conventions and regularities. The first and overarching reason is historical in the sense that "what is seen as 'academic' writing is contestable and always emergent” (Archer \& Breuer, 20I6, p. 2). This claim suggests that there is more than one way for a text to be academic. It also provides the trigger for introducing the concept and property of "academicness" as a kind of "family resemblance" - discernible across time and (con)texts but not quite the same in each individual instance. The second reason is epistemic and accounts for why "innovation" (Tardy, 20I6), "mobility" (Blommaert \& Horner, 20I7), "identity" (Ivanič, I998), "multilingualism" (Canagarajah, 2002), and evolving professional contexts (Mewburn, 2020; Paré, 2018) warrant changes in form. The epistemic reason underpins much socio-semiotic research, which has called for greater multimodality in writing practices (Archer \& Breuer, 2015; Kress, 20IO) and, more generally, in higher education (Andrews et al., 20I2; Archer \& Breuer, 2016). This research is important because by extending the concept of writing beyond language and also beyond monolingualism, socio-semiotic research suggests that diverse knowledges can emerge when writing is multimodal. These include the knowledges of the so-called "peripheral" European and Global South contexts (Bennett, 20I4; Collyer et al., 20I9; Thesen \& Cooper, 20I3) as well as the knowledges of oral cultures, whose meanings, sounds, and rhythms vanish when transcribed into standard academic writing, as evidenced by A. D. Carson's thesis Owning My Masters: The Rhetorics of Rhymes \& Revolutions (https://phd.aydeethegreat.com/) (Carson, 20I7).

A further reason to re-imagine doctoral writings relates to writer intent, namely what writers wish to achieve with their writing. This reason acknowledges that writers have choices, goals, literacies, histories, and values that warrant their autonomy in shaping how they write. In what follows, I offer a fuller account of these reasons to re-imagine doctoral writing.

\section{Family Resemblances and Academicness: What Doctoral Writings have in Common}

Notwithstanding their complexity and diversity, doctoral writings share the property of "academicness." One way of thinking about academicness is in terms of "family resemblance" (Wittgenstein, I953), whereby we acknowledge 
that there is no common distinguishing feature that characterises a member of a family, yet we recognise each member as belonging to that family. The theory of family resemblance has been mobilized across a range of disciplines, including aesthetics (Weitz, I956), the history of science (Daston \& Galison, 2007) and genre (Fishelov, 199I), because it provides a conceptual tool for classifying artefacts (including texts) according to commonalities without eclipsing their diversity and uniqueness.

Ludwig Wittgenstein's (1953) theory of family resemblances was originally articulated to explain how games as vastly different as chess, solitaire, or football have enough in common to warrant membership in a single "games family." Similarly, thinking about academic writings as belonging to a family that has "academic" resemblances can be generative because it allows us to accept similarities and differences in purpose, conventions, and form.

Academicness is also a property of texts that can be described philosophically as an organic unity (Allen, 2003) because it is holistic and non-reductive. This quality can be predicated of whole texts in such a way that does not pick out any single or uniquely identifying part of the whole. Moreover, and because of its holistic qualities, academicness cannot be reduced to any single feature of a text. This non-reductive way of thinking about academicness can help re-imagine the conditions of possibility by opening a space within which to consider a wide range of features that might contribute, holistically, to academicness. For example, what might make a text academic is not the use of any prescribed lexis or form, such as the five paragraphs of the traditional essay (Warner, 20I8) or the default IMRAD (Introduction, Methods, Results, Analysis, Discussion) thesis sequence (Paltridge \& Starfield, 2007). Rather, what makes a text academic are the ways in which it adheres holistically, as a whole, to specific socio-academic practices (Molinari, 2019).

Socio-academic practices are the social practices (Schatzki et al., 20or; Lillis et al., 2015) that relate specifically to the academy. They include acknowledging the work of others, providing evidence, arguing, and developing a stance. Socio-academic practices are underpinned by epistemic virtues, namely the social and human values that generate the practice (Harding, 1995; Wylie, 2003). These practices and their underlying values include commitments to objectivity and trained judgment (Daston \& Galison, 2007), truth or truthfulness (Connell, 20I3), academic integrity (Zgaga, 2009), social justice (Case, 2013), innovation and research (Warnock, I989), and creativity (Besley \& Peters, 2013).

When writers (and, by extension, their texts) are committed to socio-academic practices and epistemic virtues rather than to a display of form, they are more likely to mobilise a wider range of semiotic resources. This is because 
when academicness is conceived as a non-reductive property of texts, as I showcase next, there is no single a priori semiotic resource to enact it. What this means is that an image, sound, or movement (Roque, 2015) can confer academicness to a text.

\section{Troubling Epistemic Representation: The Tussle of Form and Intent}

Within its family of resemblances and in the context of academicness, what distinguishes doctoral writings from their academic "siblings" is their genre and purpose, by which I mean form and intent, respectively. For example, a doctoral thesis is longer in form than a master's dissertation, and its intent, or purpose, differs in terms of the requirement to produce "original research":

A thesis is a typewritten manuscript, usually roo to 400 pages in length, in which the student addresses a particular problem in his $[$ sic $]$ chosen field. [It] is a piece of original research, in which one must not only know the work of other scholars but also "discover" something that other scholars have not yet said. (Eco, 2015, p. 2)

Umberto Eco's purpose here is to simply provide a working definition of what a thesis is. However, it also allows me to highlight a historical and technological contingency: Before the typewriter, other technologies facilitated writing (Kelly et al., Chapter Io, this collection, also explore this topic). Since the typewriter, new technologies have emerged, each affording epistemic "losses and gains" (Bezemer \& Kress, 2008) that can "rattle the information chain" (Bazerman, 20I5). With each technological change, possibilities emerge for re-thinking how we write, what we even mean by "writing" (Harris, 2000), as well as what kinds of knowledge writing allows us to communicate (O1son, 1996). What this suggests is the possibility that knowledge need not be "typewritten" (or even written) any more than it needs to be constrained by genres and linguistic forms that have been described as "straightjackets" by Mary Hamilton and Kathy Pitt (2009) and as "pigeon-holes" by Moragh Paxton (2013). It further suggests that writers have agency in how they wish to represent knowledge because technological affordances are varied and offer possibilities rather than constraints.

Equally, academic writings do not need to be the kind of epistemological "frauds" admonished by Daniel Shanahan (2015) and by Christiaan Vinkers et al. (2015), who have highlighted how the form of the scientific article can distort the integrity of scientific practices. This happens when writers and 
publishers foreground findings to inflate their significance. The requirement to foreground findings (e.g., in the abstract) signals a commercial need to be "competitive" rather than the epistemic virtue of sharing scientific methods. In addition, the use of superlative language can aggrandise results. The claim that this kind of scientific writing is "fraudulent" exemplifies what Charles Bazerman (2015) may have had in mind when he claimed that certain forms of scientific academic writing "encapsulate" and "chain" knowledge to the interests of "university departments and businesses" rather than to the advancement of knowledge (p. 267); the "fraud" becomes manifest through the form of writing.

Taken together, what the above technological and textual affordances signal is that academic writings are already varied in form and writer intent. This offers scope for further variation, ensuring that new and diverse socio-academic practices and epistemic virtues continue to emerge. Since knowledge is complex (Parnell, 20I2), reducing its representation to one modality or genre is epistemically troubling (Atkinson, 20I3; Thomson, 2018).

Epistemic representation has been a troubled endeavour throughout the history of science (Daston \& Galison, 2007). This troubled positioning has been highlighted by writing scholars, such as Brian Paltridge and Sue Starfield (2007), who described the effect of linguistic choices on epistemic representation as follows: "Academic writing is typically viewed as largely depersonalized. Textbooks tell students that for scientific writing to be objective, it should be impersonal and use the passive voice-thus removing or reducing the presence of the researcher in the text" (p. 29). Here, they have described how the use of the passive voice affects how knowledge is represented.

A further challenge of representing sociological knowledge runs throughout John Law's 2004 book, where he lamented the "messiness" of qualitative research because it defies the linear representations required by traditional academic writing. Similarly, sociologist Howard Becker (20I7) foregrounded the disproportionate effect of using the passive to describe social phenomena. In his blog entry, Becker admonished academic sociology journals for insisting "on the most academic prose, for no reason that anyone can explain very well" (para. 6); he also noted, "Stylistically, this flattens the prose, makes it dull and boring to read" (para. 5).

My discussion, so far, has highlighted that if the positionality of the researcher can change how knowledge is represented in a text, then there may be further triggers for renewed imaginings because writers are agents who have intentions and goals and who can initiate change. Indeed, there is evidence of such triggers in how scientific writings have historically been re-shaped and 
re-imagined to reflect the epistemic virtues and social values of their time (Bazerman, 2000; Gunnarsson, 200I). This history offers further insights into the conditions of possibility that can allow us to continue re-imagining doctoral writings as contested and emergent, as I exemplify next.

\section{Evidence of Doctoral Writings Re-imagined}

In this section I will present evidence of doctoral writers who have grappled with how to represent their knowledge and, as a result, have re-imagined doctoral writing texts. I present these examples with the knowledge that this is not solely a contemporary concern. For instance, we might look to the case of Ludwig Wittgenstein (2010), whose thesis (later published as The Tractatus Logico-Philosophicus) was imagined and written as a series of aphorisms "reflecting the tension between his yearning for clear expression and his awareness that some things simply cannot be expressed" (Sigmund, 20I7, p. I28); the result was an attempt to represent non-metaphysical reality as though it were crystal clear." Each of the following examples shows that "imagination plays a crucial role" as signalled in the epigraph by Vasco d'Agnese (20I7) that opened this chapter.

\section{Owning my Masters}

A. D. Carson's 2017 musical Ph.D. dissertation, Owning My Masters: The Rhetorics of Rhymes and Revolutions (https://phd.aydeethegreat.com/), includes a timeline of social and racial movements on his university campus, a blog, music videos, and transcribed lyrics. At his defense, he performed four of his songs and showed one music video (Zamudio-Suaréz, 20I7). His intent was both academic and political, aimed at satisfying "the committee but also [at sparking] a larger discussion about race, hip-hop culture, and activism" (Zamudio-Suaréz, 2017). His thesis can be said to enact the socio-academic practice of social justice (Molinari, 2019).

\section{Unflattening}

Nick Sousanis' comic Ed.D. dissertation, which was later published in book form as Unflattening (2015), challenged the linearity and flatness of "Western" thinking and advocated interdisciplinary approaches to knowledge. This was done using illustrations to argue multimodally (cf. Gilbert, 1994). Sousanis' (2015) claim was that when academic argumentation is reduced to linear styles, including the ways it occupies page space, it risks flattening and 
narrowing perspectives on and opportunities for referring to the world. His research can be said to embody Rudolf Arnheim's (I969) epistemic virtue of interdisciplinarity and visual thinking. Sousanis' (2015) rationale for drawing his arguments is rooted in a rhetoric of visuals that can "prompt sustained reflective thinking" (Hill, 2004, p. 38) by removing the walls that words create (Sousanis, 2018).

\section{The Equidistribution of Lattice Shapes of Rings of Integers ...}

Piper Harron's (2016) playful feminist Ph.D. dissertation on mathematics was written in three different registers and for three different readers: the lay person (elementary knowers), the initiated person (secondary school maths teachers), and the expert (her examiners). She chose who she wanted her readers to be (exerting her agency and intent as a writer). She anticipated and oriented her readers' expectations by disrupting the genre of the $\mathrm{Ph} . \mathrm{D}$. thesis that assumes one type of reader (the examiners) and shared understandings of what mathematics is and who it is for. She did this because she wanted to write a thesis that was "as mathematically complete as I could honestly make it" and for a community of mathematicians who "do not feel that they are encouraged to be themselves" (Harron, 2016, p. I). By interacting with what her textual environment afforded (in terms of language and register) and by re-imagining the form her Ph.D. thesis took, she enacted the socio-academic practice and epistemic virtue of inclusion and social justice.

\section{Writing the Thesis in Languages Other Than English}

Hleze Kunju (20I7) wrote his thesis in isiXhosa, one of South Africa's eleven languages. In so doing, he enacted an ideological stance that consisted of reclaiming an Indigenous language as academic and challenging what has been pointed out as the dominant geopolitics of academic English (Lillis \& Curry, 2oro; Politzer-Ahles et al., 2or6). Similarly, Peruvian doctoral researcher Roxana Quispe Collantes wrote and defended her thesis in Quechua, the main language of the ancient Incan Empire (Collyns, 2019; Jones, 2019). By writing in isiXhosa and Quechua, respectively, both researchers were "enacting and creating identities and ideologies” (Roozen, 2015, p. 50) as agents who recognised the affordances of their textual environments (English, 20Ir; Williams, 20I7).

The above examples show that doctoral writings are already being re-imagined with the intention of broadening epistemic representations and values. 
They signal that researchers and their supervisors already question the conventions that Lucia Thesen and Linda Cooper (2013) have cautioned against:

"How to Books" on academic writing ... tend to over-generalise, over-simplify, de-skill students, ... implicitly and explicitly perpetuating a restricted and deficit model of student competence and language use. The guides ... tend to focus on how students can imitate existing conventions based on massively problematic assumptions about student homogeneity and the stability of the disciplines. (p. 4)

The reason why "homogeneity and ... stability" are "problematic assumptions" is that, as we have just seen, doctoral researchers and their intents are heterogenous, as are the socio-academic practices and epistemic virtues that underscore their research. Such heterogeneity is likely to warrant further re-imaginings.

\section{Academic Writings as "Open Systems": Toward a Critical Realist Perspective}

To explain why doctoral writings are and can continue to be re-imagined, I draw on theoretical frameworks that are not established in current academic writing literatures. They are, nonetheless, relevant. These include the philosophy and sociology of critical realism as well as complexity theory and open and emergent systems (Collier, I994; Kuhn, 2008; Larsen-Freeman \& Cameron, 2008; Mason, 2008; Parnell, 20I2; Sawyer, 200I), all of which underpin critical realist philosophy. These theories complement established studies on academic writing by making explicit the social ontologies and epistemologies that underpin social practice theories of writing (see van Schalkwyk \& Jacobs, Chapter 4, this collection). After introducing these theories, I outline their relevance to the project of re-imagining doctoral writing.

\section{Critical Realism: A Philosophy of Change}

Critical realism is a philosophy of social science associated with Roy Bhaskar (1989, 1998) and further developed by Margaret Archer (1995, 2000, 2003; Archer et al., 1998). It has roots in Kantian metaphysics and Marxist materialism. Its ambition has been to transcend positivist accounts of social reality, on the one hand, and constructivist ontologies, on the other. This is because, critical realists have argued, both these theoretical frameworks are inadequate to explain social phenomena. Positivism fails because it reifies objectivity by 
purporting to make value-free judgments about the nature of reality; it also favours deterministic and mechanistic explanations that undermine agency. Constructivism is inadequate because it tends to relativise judgements about what counts as real (Collier, 1994), potentially undermining social reality by over-emphasising the role that agents play in constructing it. Instead, critical realists have argued that ontological claims about the reality of social phenomena (such as social structures) are justified because social reality is not a construct, it is real. At the same time, the reality of the social world is shaped by and can be changed by individuals (agents). Critical realists have argued that individuals, including scientists/researchers, do not simply describe the world, they judge it through value claims. These value claims are what enable individuals to then intervene critically in changing social reality.

This emphasis on critical social intervention is relevant to re-imagining doctoral writings because it affords the conditions of possibility that are needed for changes in writing practices to emerge. We know from research on academic literacies that academic writing is a social practice (Lea \& Street, I998; Lillis \& Scott, 2007). In this sense, it is a real social phenomenon governed by structures (e.g., rules and conventions) that bind writers. A critical realist lens, however, emphasises that writers have agency to intervene, re-imagine, and change those structures. Writing scholars who have argued along these lines include Donald Judd (2003) and Deirdre Pratt (20II). Researchers working in the field of higher education have included Jennifer Case (2013) as well as Chrissie Boughey and Sioux McKenna (Boughey \& McKenna, 202I), all of whom work or have worked in South African and post-Apartheid education. The uptake of critical realist theory in educational contexts affected by systemic inequalities of access is particularly worthy of note because it indexes the generative and transformative potential of the theory.

Three inter-related concepts that are especially relevant to this discussion underpin critical realist philosophy. These are complexity theory, open systems, and emergence. Understanding each one in connection with the other can help re-imagine the social structures that shape doctoral writings in ways that are non-reductive and non-deterministic, thus opening possibilities for enacting change in doctoral writing.

\section{Complexity Theory}

Complexity theorists argue that the behavior of a whole is distinct from the behavior of the individual parts that constitute that whole. Because of this, complex reality is referred to as non-linear since it cannot be straightforwardly explained by reducing it sequentially and mechanistically to a finite set of 
causes (Larsen-Freeman \& Cameron, 2008; Mason, 2008; Parnell, 20I2). This is what makes reality complex as opposed to complicated. A sailor's knot is complicated but not complex because it is possible to mechanically trace the sequence of steps that created the knot in a way that is linear, where each step adds up to determine and predict a final outcome. The chemical formula for water $\left(\mathrm{H}_{2} \mathrm{O}\right)$, on the other hand, is complex because the characteristics of the whole - a liquid - are both quantitatively and qualitatively distinct from the characteristics of its constituent elements-gases.

The significance of complex non-linear explanations is that they exemplify how novel phenomena, such as liquids, emerge from qualitatively and quantitatively distinct constituents, such as gases. Novelty becomes possible because what causes a complex phenomenon is disproportionate or not comparable to the phenomenon itself (Ball, 2004). This can be illustrated with reference to social phenomena such as crowd behavior, the reality of which, as a whole, is disproportionate to its cause(s) or constituent parts. For example, crowd behavior is often characterized by its roaring noise, threatening mass, and unstoppable momentum. Yet, this reality is distinct from the behavior of any single individual that constitutes the crowd. Although individuals cause the crowd to exist in the sense that crowds are made of individuals, the crowd's behavior and characteristics are distinct from those of any specific individual. The crowd's roar or threat cannot be reduced to the cries or protests of any single individual. Rather, the crowd's behavior emerges as distinct from the interaction of multiple variables that are not individually responsible for the noise or danger generated by the whole (such variables include police blocks, the weather, or a single person, each of which, as a single variable, neither "roars" nor "threatens").

Similarly, if academic writings are understood as being social practices, then they can be classified as complex phenomena. This is because texts are made up of parts-such as lexis, grammar, paragraphs, moves, or conventions-that form a whole-such as a social, cognitive, or activity-oriented genre (Bruce, 2008; Hyland, 2002a; Russell, 1997). This whole behaves and is perceived in ways that differ to those of its constituent parts. For example, the arguably innocuous personal pronoun "I" can have a disproportionate overall effect on the writing as a whole. It can make a text as a whole seem subjective or informal (Bailey, 2006) and potentially lead to unintended consequences, such as undermining the objective undertaking of somebody's research. Yet, the use of "I," in and of itself, does not make a text inherently subjective. Rather, what confers a subjective feel or voice to a text is the range and interaction of rhetorical and discursive devices with shared disciplinary conventions and understandings (Hyland, 200I, 2002b; Matsuda \& Tardy, 2008; Tang \& John, 
1999). In this sense, the holistic subjective quality of a whole text cannot be reduced to any single textual feature, including the use of "I."

Moreover, because of their non-linearity, complex systems make it harder to predict the effect of any given cause, such as a linguistic choice, or to isolate a single cause as being responsible for any given effect, such as the subjectivity or objectivity of a text. Rather than a mechanistic aggregate composed of concatenated parts that add up to a whole-as cookie-cutter (Bazerman, 2000, p. 8) and template (Nesi \& Gardner, 20I2, p. 2) approaches to writing encourage-social practice framings of academic writing are dynamic and transformative systems where multiple variables interact to allow diverse texts to emerge (Lillis, 2013). These interactions have multiple causes that cannot be reduced to constituent parts in any linear, mechanistic manner. What makes Harron's (20I6) thesis academic as a whole, for example, cannot be traced back in a linear way to any specific parts of it, such as the words or arrangement of her text. Instead, what makes her text academic are a range of inter-related socio-academic variables and epistemic virtues that ensure her thesis adheres to rigorous academic standards.

\section{Open Systems and Emergence}

The complexity described above is related to a notion that is fundamental to critical realism: the notion of open systems and what emerges from them. Open systems are characterized by multiple variables and interactions that enable new phenomena to emerge (Fodor, 1974). A human body is an open system: It emerges from countless variables and their interactions. Once a whole phenomenon has emerged (i.e., a social, political, psychological human being, not just a biological body), it can no longer be reduced to and identified with any one of its physical constituent parts (e.g., body shape).

Another way of understanding open systems is to compare them to closed ones (Collier, 1994). Closed systems are artificially created conditions designed to isolate mechanisms so they can be observed in the absence of putatively irrelevant causal variables. For example, if I want to know what causes light to refract, all I need is a source of light and a medium through which it can pass, such as a prism. I do not need trees, houses, rain, or anything else that co-occurs naturally when light refracts in the environment because these elements are not causally relevant to the refraction of light.

Doctoral writings, similar to human beings, however, are characterized by naturally co-occurring events. They are open to variables that have causal relevance. These variables include the purposes, languages, values, and literacies of researchers (the agents) as well as myriad environmental structures (e.g., 
socio-academic practices, epistemic virtues, institutional conventions and constraints). In this sense, academic writings are not closed texts. However, an International English Language Testing System (IELTS) essay could be described as closed because all it needs to be successful are isolated features, such as standardized paragraphs or linguistic devices, that do not reflect the naturally-occurring influences that shape academic writing and affect language choice, such as disciplinary genres, citation practices, and voice (Ivanič \& Simpson, 1992).

In her insightful re-imagining of the "conditions of possibility for the Ph.D.," Jude Fransman (20I2) likened open systems to maps because they afford the "organisation of reality" rather than "the reproduction of a prior organisation," explaining, "The map is ... detachable, reversible, susceptible to constant modification. It can be torn, reversed, adapted to any kind of mounting, reworked by an individual, group or social formation" (p. I40). This suggests that because they are not determined by a single use or purpose, maps are open to change.

A critical realist understanding of open systems might echo Fransman's (20I2) reference to maps in so far as open systems are "susceptible to ... modification" (p. I40) because they are permeable. This means energy and matter can be exchanged between the system (e.g., the writing) and its environment (e.g., prevailing conventions or society) whilst preserving the identity of both the system and the environment. Naturally occurring phenomena, such as rivers, cells, and humans, are examples of open systems because they are self-contained, but they are also susceptible to modification by their environments. Their identity as rivers, cells, and humans remains constant and recognisable, but their forms and purposes can change as they interact with their environments. Their identities can be said to emerge from this interaction. Similarly, the identities of doctoral writings can remain constant and recognizable despite changes in their form and purpose (cf. earlier reference to family resemblance).

Emergence, here, is a key concept that is powerful and generative for re-imagining writing. This is because it enables us to talk meaningfully about conditions of possibility, novelty, and change. A simple way to understand this concept was offered by philosopher Jaegwon Kim (2006): "A purely physical system, composed exclusively of bits of matter, when it reaches a certain degree of complexity in its structural organisation, can begin to exhibit genuinely novel properties not possessed by its simpler constituents" (p. 548). The literatures on emergence theory are too vast to summarise here (see, for example, Ablowitz, 1939; Chalmers, 2008; Sawyer, 200I; Taylor, 2015). What they have in common and is relevant to this discussion is a concern 
with how novelty, both social and physical, can be explained in ways that are non-reductive and non-deterministic. When novelty is explained in this non-deterministic way, it can create conditions of possibility that then lead to change, with change being key to critical realist philosophy. Since a concern with change is also central to re-imagining doctoral writings, further research in this area might offer fresh insights into how theories of emergence could provide a foundational and generative conceptual toolkit for their ongoing re-imagination.

Re-imagining doctoral writings as open systems would allow them to be conceived as emergent socio-academic practices that represent a wide(r) range of epistemic virtues. This would warrant drawing on the representational affordances of a far broader and diverse socio-semiotic landscape.

\section{Making it Happen: Communities of Support}

Doctoral researchers do not work in isolation. Their agencies interact with those of their supervisors who operate within established university structures and expectations. This can be a challenge when it comes to re-imagining doctoral writing. However, just as there are established standards and conventions, there is an equally established and growing community of scholars who can provide the inspiration, solidarity, and tools with which to re-imagine. I hope that my theorization of academic writing as an emergent open system can contribute to the conceptual foundations that already underpin the important work of this community.

The community of support includes Fiona English (20II, 20I5), whose socio-semiotic reconfiguration of written knowledge has drawn on the work of Gunther Kress and extended it to provide examples of how academic writers and those who support them can "re-genre" (20II) their work in creative and critical ways. In Thesen and Cooper's (2013) edited collection, authors showcased examples of how doctoral writers and their supervisors negotiated choices for representing knowledge. They highlighted both the tensions and possibilities that emerge from this process, particularly within the multilingual and multi-literacy spaces that characterize South African higher education. The work of independent scholar Helen Kara (2015; Kara \& Brooks, 2020; Phillips \& Kara, 202I) is also relevant to the project of re-imagining how research gets written. In her works, Kara has highlighted the value of creative research methods in representing Indigenous knowledges and in broadening our understandings of ethical practices. And last but not least, there is the work of Dely Lazarte Elliot et al. (2020), who have described doctoral research as a landscape of hidden opportunities and constraints that 
affords exploration, digression, and innovation. The conditions of possibility available in this landscape are further evident in Catherine Manathunga's (2020) blog entry on decolonising doctoral writing; as Manathunga explained in her entry, she drew explicitly on Boaventura de Sousa Santos' 20r4 idea of "sociologies of emergence" (as cited in para. I) to make the case for re-imagining how doctoral researchers write and what they write about. She also included several examples of re-imagined theses.

\section{Concluding Thoughts}

The reasons to re-imagine doctoral writings discussed in this chapter can be summarized as follows: First, academic writings already exhibit considerable diversity, even within their family resemblances (Wittgenstein, 1953) and across their shared property of academicness. This suggests that the conditions of possibility for re-imagining academic writing are already in place and afford a conceptual space within which to imagine further. Second, there are epistemic reasons for re-thinking how we write. These include the fact that semiotic choices affect the representation of socio-academic practices and epistemic virtues. Several examples were given in this chapter of doctoral writers who have re-imagined their writing for these reasons.

Drawing on the philosophy of critical realism and its framing of complex open systems as emergent, I suggested how and why change in academic writing continues to be possible. I argued that when academic writings, of which doctoral writings are a part, are conceived as permeable and emergent open systems, they can change and adapt in response to the intentions of their authors and to the environments to which they belong. I concluded this chapter by sharing the work of scholars who are already nurturing a community of writers actively engaged in re-imagining doctoral writings.

The significance of this chapter for doctoral writing researchers is that critical realism provides a systematic and critical space within which researchers can explain changes in social phenomena, which include doctoral writings and affords a theoretical foundation for continuing to re-imagine conditions of possibility.

\section{References}

Ablowitz, R. (1939). The theory of emergence. Philosophy of Science, 6(1), 1-16. https://doi.org/10.1086/286529

Allen, J. (2003). G.E. Moore and the principle of organic unity. Journal of Value Inquiry, 37(3), 329-339. https://doi.org/10.1023/B:INQU.0000013345.47521.35 
Andrews, R., Borg, E., Boyd Davis, S., Domingo, M., \& England, J. (Eds.). (2012). The SAGE handbook of digital dissertations and theses. SAGE Publishing. https:// dx.doi.org/10.4135/9781446201039

Archer, A., \& Breuer, E. (Eds.). (2015). Multimodality in writing: The state of the art in theory, methodology and pedagogy. Brill. https://brill.com/view/title/31805

Archer, A., \& Breuer, E. (Eds.). (2016). Multimodality in higher education. Brill. https://brill.com/view/title/32825

Archer, M., Bhaskar, R., Collier, A., Lawson, T., \& Norrie, A. (Eds.) (1998). Critical realism: Essential readings. Routledge. https://doi.org/10.4324/9781315008592

Archer, M. S. (1995). Realist social theory: The morphogenetic approach. Cambridge University Press. https://doi.org/10.1017/CBO9780511557675

Archer, M. S. (2000). Being buman: The problem of agency. Cambridge University Press. https://doi.org/10.1017/CBO9780511488733

Archer, M. S. (2003). Structure, agency, and the internal conversation. Cambridge University Press. https://doi.org/10.1017/CBO9781139087315

Arnheim, R. (1969). Visual thinking. University of California Press.

Atkinson, P. (2013). Ethnographic writing, the avant-garde and a failure of nerve. International Review of Qualitative Research, 6(1), 19-35. https://doi.org/10.1525/ irqr.2013.6.1.19

Bailey, S. (2006). Academic writing: A handbook for international students (2nd ed.). Routledge.

Ball, P. (2004). Critical mass: How one thing leads to another. Heinemann.

Bazerman, C. (2000). Shaping written knowledge: The genre and activity of the experimental article in science. The WAC Clearinghouse. https://wac.colostate.edu/ books/landmarks/bazerman-shaping/ (Originally published 1988 by University of Wisconsin Press).

Bazerman, C. (2015). Afterword: Social changes in science communication: Rattling the information chain. In A. G. Gross \& J. Ruehl (Eds.), Science and the internet: Communicating knowledge in a digital age (pp. 267-281). Routledge.

Becker, H. S. (n.d.). Some words about writing. Writing on Writing. Retrieved April 28, 2021, from https://web.archive.org/web/20161202024316/https://www.dur. ac.uk/writingacrossboundaries/writingonwriting/howardsbecker/

Bennett, K. (Ed.). (2014). The semiperiphery of academic writing: Discourses, communities and practices. Palgrave Macmillan. https://doi.org/10.1057/9781137351197

Besley, T. (A. C.), \& Peters, M. A. (Eds.) (2013). Re-imagining the creative university for the 21st century. Brill. https://brill.com/view/title/37464

Bezemer, J., \& Kress, G. (2008). Writing in multimodal texts: A social semiotic account of designs for learning. Written Communication, 25(2), 166-195. https:// doi.org/10.1177/0741088307313177

Bhaskar, R. (1989). Reclaiming reality: A critical introduction to contemporary philosophy. Verso.

Bhaskar, R. (1998). The possibility of naturalism: A philosophical critique of the contemporary buman sciences ( 3 rd ed.). Routledge.

Blommaert, J., \& Horner, B. (2017). Mobility and academic literacies: An epistolary 
conversation. London Review of Education, 15(1), 2-20. https://doi.org/10.18546/ LRE.15.1.02

Boughey, C., \& McKenna, S. (2021). Understanding higher education: Alternative perspectives. African Minds.

Bruce, I. (2008). Academic writing and genre: A systematic analysis. Continuum.

Canagarajah, A. S. (2002). Critical academic writing and multilingual students. University of Michigan Press. https://doi.org/10.3998/mpub.8903

Case, J. M. (2013). Researching student learning in higher education: A social realist approach. Routledge. https://doi.org/10.4324/9780203797402

Chalmers, D. J. (2008). Strong and weak emergence. In P. Clayton \& P. Davies (Eds.), The re-emergence of emergence: The emergentist hypothesis from science to religion. Oxford University Press. https://doi.org/10.1093/acprof:oso/9780199544318.003.0011

Collier, A. (1994). Critical realism: An introduction to Roy Bhaskar's philosophy. Verso Books.

Collyer, F., Connell, R., Maia, J., \& Morrell, R. (2019). Knowledge and global power: Making new sciences in the South. Monash University Publishing.

Collyns, D. (2019, October 27). Student in Peru makes history by writing thesis in the Incas' language. The Guardian. https://www.theguardian.com/world/2019/ oct/27/peru-student-roxana-quispe-collantes-thesis-inca-language-quechua

Connell, R. (2013). The neoliberal cascade and education: An essay on the market agenda and its consequences. Critical Studies in Education, 54(2), 99-112. https:// doi.org/10.1080/17508487.2013.776990

d'Agnese, V. (2017). The eclipse of imagination within educational "official" framework and why it should be returned to educational discourse: A Deweyan perspective. Studies in Philosophy and Education, 36(4), 443-462. https://doi. org/10.1007/s11217-016-9511-x

Daston, L., \& Galison, P. (2007). Objectivity. Zone Books.

Devitt, A. J. (1996). Genre, genres, and the teaching of genre. College Composition and Communication, 47(4), 605-615. https://doi.org/10.2307/358606

Eco, Umberto. (2015). How to write a thesis (C. Mongiat Farina \& G. Farina, Trans.). MIT Press.

Elliot, D. L., Bengtsen, S. S. E., Guccione, K., \& Kobayashi, S. (2020). The hidden curriculum in doctoral education. Palgrave Pivot. https://doi.org/10.1007/978-3030-41497-9

English, F. (2011). Student writing and genre: Reconfiguring academic knowledge. Continuum.

English, F. (2015). Writing differently: Creating different spaces for student learning. In A. Chik, T. Costley, \& M. C. Pennington (Eds.), Creativity and discovery in the university writing class: A teacher's guide. Equinox.

Fishelov, D. (1991). Genre theory and family resemblance-revisited. Poetics, 2O(2), 123-138. https://doi.org/10.1016/0304-422X(91)90002-7

Fodor, J. A. (1974). Special sciences (or: The disunity of science as a working hypothesis). Synthese, 28(2), 97-115. https://doi.org/10.1007/BF00485230 
Fransman, J. (2012). Re-imagining the conditions of possibility of a $\mathrm{PhD}$ Thesis. In R. Andrews, E. Borg, S. Boyd Davis, M. Domingo, \& J. England (Eds.), The SAGE handbook of digital dissertations and theses (pp. 138-156). SAGE Publishing. https://doi.org/10.4135/9781446201039.n9

Gilbert, M. A. (1994). Multi-modal argumentation. Philosophy of the Social Sciences, 24(2), 159-177. https://doi.org/10.1177/004839319402400202

Gunnarsson, B.-L. (2001). Expressing criticism and evaluation during three centuries. Journal of Historical Pragmatics, 2(1), 115-139. https://doi.org/10.1075/ jhp.2.1.06gun

Hamilton, M., \& Pitt, K. (2009). Creativity in academic writing: Escaping from the straightjacket of genre. In A. Carter, T. Lillis, \& S. Parkin (Eds.), Why writing matters: Issues of access and identity in writing research and pedagogy (pp. 61-79). John Benjamins Publishing Company. https://doi.org/10.1075/ swll.12.12ham

Harding, S. (1995). "Strong objectivity": A response to the new objectivity question. Synthese, 104(3), 331-349. https://doi.org/10.1007/BF01064504

Harris, R. (2000). Rethinking writing. Athlone.

Harron, P. A. (2016). The equidistribution of lattice lhapes of rings of integers of cubic, quartic, and quintic number fields: An artist's rendering: Based on the original story by Manjul Bhargava and Piper Harron [Doctoral Dissertation, Princeton University]. The Liberated Mathematician. http://www.theliberatedmathematician.com/ wp-content/uploads/2015/11/PiperThesisPostPrint.pdf

Hill, C. A. (2004). The psychology of rhetorical images. In C. A. Hill \& M. Helmers (Eds.), Defining visual rhetorics (pp. 25-40). Routledge.

Hyland, K. (2001). Humble servants of the discipline? Self-mention in research articles. English for Specific Purposes, 20(3), 207-226. https://doi.org/10.1016/ S0889-4906(00)00012-0

Hyland, K. (2002a). Genre-based pedagogies: A social response to process. Journal of Second Language Writing, 12(1), 17-29. https://doi.org/10.1016/S1060$3743(02) 00124-8$

Hyland, K. (2002b). Options of identity in academic writing. ELT Journal, 56(4), 351-358. https://doi.org/10.1093/elt/56.4.351

Ivanič, R. (1998). Writing and identity: The discoursal construction of identity in academic writing. John Benjamins Publishing Company. https://doi.org/10.1075/swll.5

Ivanič, R., \& Simpson, J. (1992). Who's who in academic writing. In N. Fairclough (Ed.), Critical language awareness. Routledge.

Jones, J. (2019). Peruvian scholar writes and defends the first thesis written in Quechua, the main language of the Incan Empire. Open Culture. http://www.openculture. com/2019/10/peruvian-scholar-writes-defends-the-first-thesis-written-in-quechua.html

Judd, D. (2003). Critical realism and composition theory. Routledge. https://doi. org/10.4324/9780203986707

Kara, H. (2015). Creative research methods in the social sciences: A practical guide. Policy Press. https://doi.org/10.2307/j.ctt1t88xn4 
Kara, H., \& Brooks, J. (2020). The potential role of comics in teaching qualitative research methods. The Qualitative Report, 25(7), 1754-1765. https://doi. org $/ 10.46743 / 2160-3715 / 2020.4341$

Kim, J. (2006). Emergence: Core ideas and issues. Synthese, 151(3), 547-559. https:// doi.org/10.1007/s11229-006-9025-0

Kress, G. (2010). Multimodality: A social semiotic approach to contemporary communication. Routledge. https://doi.org/10.4324/9780203970034

Kuhn, L. (2008). Complexity and educational research: A critical reflection. Educational Philosophy and Theory, 4O(1), 177-189. https://doi.org/10.1111/j.14695812.2007.00398.x

Kunju, H.W. (2017). IsiXhosa ulwimi lwabantu abangesosininzi eZimbabwe: Ukuphila nokulondolozwa kwaso [Doctoral thesis, Rhodes University]. SEALS Digital Commons. http://vital.seals.ac.za:8080/vital/access/services/Download/ vital:21250/SOURCE1

Larsen-Freeman, D., \& Cameron, L. (2008). Complex systems and applied linguistics. Oxford University Press.

Law, J. (2004). After method: Mess in social science research. Routledge. https://doi. org/10.4324/9780203481141

Lea, M. R., \& Street, B. V. (1998). Student writing in higher education: An academic literacies approach. Studies in Higher Education, 23(2), 157-172. https://doi.org/ 10.1080/03075079812331380364

Lillis, T. (2013). The sociolinguistics of writing. Edinburgh University Press.

Lillis, T., \& Curry, M. J. (2010). Academic writing in a global context: The politics and practices of publishing in English. Routledge.

Lillis, T., Harrington, K., Lea, M. R., \& Mitchell, S. (Eds.). (2015). Working with academic literacies: Case studies towards transformative practice. The WAC Clearinghouse; Parlor Press. https://doi.org/10.37514/PER-B.2015.0674

Lillis, T., \& Scott, M. (2007). Defining academic literacies research: Issues of epistemology, ideology and strategy. Journal of Applied Linguistics and Professional Practice, 4(1), 5-32. https://doi.org/10.1558/japl.v4i1.5

Manathunga, C. (2020, July 9). Decolonising doctoral education: Sociologies of emergence? The hidden curriculum in doctoral education. https://drhiddencurriculum.wordpress.com/2020/07/09/decolonising-doctoral-education-sociologies-of-emergence/

Mason, M. (2008). What is complexity theory and what are its implications for educational change? Educational Philosophy and Theory, 4O(1), 35-49. https://doi. org/10.1111/j.1469-5812.2007.00413.x

Matsuda, P. K., \& Tardy, C. M. (2008). Continuing the conversation on voice in academic writing. English for Specific Purposes, 27(1), 100-105. https://doi. org/10.1016/j.esp.2007.04.002

Mewburn, I. (2020, May 13). Where I call bullshit on the way we do the $\mathrm{PhD}$. The Thesis Whisperer. https://thesiswhisperer.com/2020/05/13/stop-letting-theghosts-of-old-academia-haunt-you/

Molinari, J. (2019). What makes writing academic: An educational and philosophical 
response [Ph.D. thesis, University of Nottingham]. Nottingham ePrints. http:// eprints.nottingham.ac.uk/id/eprint/59439

Nesi, H., \& Gardner, S. (2012). Genres across the disciplines: Student writing in higher education. Cambridge University Press.

Olson, D. (1996). The world on paper: The conceptual and cognitive implications of writing and reading. Cambridge University Press

Paltridge, B., \& Starfield, S. (2007). Thesis and dissertation writing in a second language: A handbook for supervisors. Routledge.

Paré, A. (2018). Re-writing the doctorate: New contexts, identities, and genres. Journal of Second Language Writing, 43, 80-84. https://doi.org/10.1016/j. jslw.2018.08.004

Parnell, J. E. (2012). Complexity theory. In R. Andrews, E. Borg, S. Boyd Davis, M. Domingo, \& J. England (Eds.), The SAGE handbook of digital dissertations and theses (pp. 120-137). SAGE Publishing. https://dx.doi. org/10.4135/9781446201039.n8

Paxton, M. (2013). Genre: A pigeonhole or a pigeon? Case studies of the dilemmas posed by the writing of academic research proposals. In L. Thesen \& L. Cooper (Eds.), Risk in academic writing: postgraduate students, their teachers and the making of knowledge (pp. 148-165). Multilingual Matters.

Phillips, R., \& Kara, H. (2021). Creative writing for social research: A practical guide. Policy Press.

Politzer-Ahles, S., Holliday, J. J., Girolamo, T., Spychalska, M., \& Harper Berkson, K. (2016). Is linguistic injustice a myth? A response to Hyland (2016). Journal of Second Language Writing, 34, 3-8. https://doi.org/10.1016/j.jslw.2016.09.003

Pratt, D. (2011). Modelling written communication: A new systems approach to modelling in the social sciences. Springer.

Roque, G. (2015). Should visual arguments be propositional in order to be arguments? Argumentation, 29(2), 177-195. https://doi.org/10.1007/s10503-014-9341-3

Russell, D. R. (1997). Rethinking genre in school and society: An activity theory analysis. Written Communication, 14(4), 504-554. https://doi. org/10.1177/0741088397014004004

Sawyer, R. K. (2001). Emergence in sociology: Contemporary philosophy of mind and some implications for sociological theory. American Journal of Sociology, 107(3), 551-585. http://iscte.pt/ jmal/mcc/Keith_Sawyer_Emergence_in_Sociology.pdf

Schatzki, T. R., Knorr Cetina, K., \& von Savigny, E. (Eds.). (2001). The practice turn in contemporary theory. Routledge. https://doi.org/10.4324/9780203977453

Shanahan, D. R. (2015). A living document: Reincarnating the research. Trials, 16, Article 151. https://doi.org/10.1186/s13063-015-0666-5

Sigmund, K. (2017). Exact thinking in demented times: The Vienna Circle and the epic quest for the foundations of science. Basic Books, Hachette Book Group.

Sousanis, N. (2015). Unflattening. Harvard University Press.

Sousanis, N. (2018). Thinking in comics: An emerging process. In M. Cahnmann-Taylor \& R. Siegesmund (Eds.), Arts-based research in education: foundations for practice (2nd ed., pp. 190-198). Routledge. 
Tang, R., \& John, S. (1999). The 'I' in identity: Exploring writer identity in student academic writing through the first person pronoun. English for Specific Purposes, 18(Suppl. 1), S23-S39. https://doi.org/10.1016/S0889-4906(99)00009-5

Tardy, C. M. (2016). Beyond convention: Genre innovation in academic writing. University of Michigan Press. https://doi.org/10.3998/mpub.5173647

Taylor, E. (2015). An explication of emergence. Philosophical Studies, 172(3), 653-669. https://doi.org/10.1007/s11098-014-0324-x

Thesen, L., \& Cooper, L. (Eds.). (2013). Risk in academic writing: Postgraduate students, their teachers and the making of knowledge. Multilingual Matters.

Thomson, P. (2015, September 28). Are we stuck in a Gutenberg time-warp? Patter. https://patthomson.net/2015/09/28/are-we-stuck-a-gutenberg-time-warp/

Thomson, P. (2018). Troubling writing as 'representation'. In B. Jeffrey \& L. Russell (Eds.), Writing for ethnography. Ethnography and Education Press.

Vinkers, C. H., Tijdink, J. K., \& Otte, W. M. (2015). Use of positive and negative words in scientific PubMed abstracts between 1974 and 2014: Retrospective analysis. BMJ, 351, Article h6467. https://doi.org/10.1136/bmj.h6467

Warner, J. (2018). Why they can't write: Killing the five-paragraph essay and other necessities. John Hopkins University Press. https://doi.org/10.1353/book.61976

Weitz, M. (1956). The role of theory in aesthetics. The Journal of Aesthetics and Art Criticism, 15(1), 27-35. https://doi.org/10.1111/1540_6245.jaac15.1.0027

Williams, B. T. (2017). Literacy practices and perceptions of agency: Composing identities. Routledge. https://doi.org/10.4324/9781315619095

Wittgenstein, L. (1953). Philosophical investigations (G. E. M. Anscombe, Trans). Basil Blackwell.

Wittgenstein, L. (with Russell, B.). (2010). Tractatus logico-philosophicus. Project Gutenberg. https://www.gutenberg.org/files/5740/5740-pdf.pdf (Original work published 1922 by Harcourt, Brace \& Company)

Wolff, J. (2007, September 4). Literary boredom. The Guardian. https://www. theguardian.com/education/2007/sep/04/highereducation.news

Wylie, A. (2003). Why standpoint matters. In R. Figueroa \& S. Harding (Eds.), Science and other cultures: Issues in philosophies of science and technology (pp. 26-48). Routledge.

Zamudio-Suaréz, F. (2017, February 27). An activist defends his dissertation in rap. The Chronicle of Higher Education. https://www.chronicle.com/article/An-Activist-Defends-His/239335

Zgaga, P. (2009). Higher education and citizenship: 'The full range of purposes.' European Educational Research Journal, 8(2), 175-188. https://doi.org/10.2304/ eerj.2009.8.2.175 



\title{
Ph.D. by Publication or Monograph Thesis? Supervisors and Candidates Negotiating the Purpose of the Thesis when Choosing Between Formats
}

\author{
Signe Skov \\ Roskilde University
}

\begin{abstract}
In this chapter, I investigate how the Ph.D. by publication has become more and more prevalent within the humanities and the social sciences over the last couple of decades in Denmark. Based on interviews with Ph.D. supervisors and doctoral candidates at two Danish universities, I analyze how they articulate, construct, and imagine the thesis when they legitimize their choice of and preference for thesis format, be it the monograph thesis or the Ph.D. by publication. This analysis shows how the choice of thesis format is most often legitimized through instrumental discourses, emphasizing what it does for individuals or institutions rather than what it does for disciplines and knowledge. Terms like completion, results, competency, career, status, statistics, and return on investment are common-foregrounding how the thesis contributes to individual or institutional performance. Interestingly, within this instrumental way of talking and thinking about the thesis, the monograph thesis is beginning to be seen as a less ideal or legitimate format and the Ph.D. by publication is being seen as a more obvious choice. Alongside these instrumental ideas and imaginings, there are other discourses at work imagining the thesis in terms of being an intellectual endeavor, a process of inquiry and knowledge transformation, and a contributor to knowledge and disciplines. Nevertheless, in this chapter I show how drawing on intellectual discourses alone is insufficient when it comes to arguing for participants' choice of thesis format regardless if it is the monograph thesis or the Ph.D. by publication.
\end{abstract}


Over the last couple of decades, we have witnessed significant changes within doctoral education in the Nordic countries as well as internationally. These changes include a growth in enrollment rates and increasingly diverse candidates; an increased focus on quality assurance, accountability, and completion times; growing pressure to publish during candidature; and increased international competition (Aitchison et al., 2012; Burford, 2017; Manathunga, 2019). These changes have often been discussed in the literature as related to the global knowledge economy, neoliberal ideologies, and new practices of managerialism that focus on efficiency, accountability, and performance (Boud \& Lee, 2009; Davies \& Petersen, 2005; Shore \& Wright, 2016) Among these shifts, we also find changes in the final text for examination: the dissertation or thesis. More recently, the Ph.D. by publication has become an increasingly common format, appearing alongside the monograph thesis within the humanities and social sciences, particularly in Denmark and other Nordic countries (de Lange, 20I3; Herrmann et al., 20I3; Uddannelses- og Forskningsministeriet, 20I7a). The rise of the Ph.D. by publication is, in the international literature on doctoral writing, often described as a response to the global knowledge economy within which scientific articles are conceptualized as the result of an investment (Aitchison et al., 2012; Barnacle, 2005; Kamler \& Thomson, 20I4). In this vein, David Boud and Alison Lee (2009) discussed how the growth in Ph.D.s by publication can be seen as a consequence of a neoliberal ideology, among other things, which brings forward a tendency to focus on performance-based metrics; as they put it, the rapid expansion of "doctorates by publication ... are a visible response to policy-led pressures for research productivity within the 'performative' university" (p. 7).

In Danish legislation, both the monograph thesis and the Ph.D. by publication are considered equals (Uddannelses- og Forskningsministeriet, 2013). However, the Ph.D. by publication is becoming more and more prevalent. In this chapter, I explore how choices of thesis formats are negotiated among doctoral candidates and supervisors at two universities in Denmark. I am curious about the specific ways in which speakers talk about and legitimize their decisions regarding their chosen thesis format. I am interested in the ideas - the imaginings of the thesis — held by local stakeholders, making one thesis format more "relevant" than the other.

I begin by first unpacking my theoretical perspectives and the specific study that this chapter builds on. I follow this with an analysis of my interviews with Ph.D. supervisors and doctoral candidates-I focus particularly on the discourses used to legitimize choices of thesis format. I am interested in how language choices shape the format of the thesis in certain ways, especially through the use of two discourses that I have found to be particularly 
dominant in my study. I refer to these discourses as instrumental discourses and intellectual discourses. I describe both discourses briefly before showing the two discourses at work via excerpts from my interviews. Finally, I discuss which of the discourses seem to be the most powerful in imagining the thesis and the implications of this for doctoral thesis writing ${ }^{1}$.

\section{Theoretical Perspectives}

Much of the current research about doctoral thesis writing takes a social practice approach to writing. Within this framework, writing is conceived as a social action, as opposed to an individual or isolated activity, and as an act-something performed rather than a transparent tool for representing and reflecting reality. Furthermore, writing is conceived of as a practice bound up with, embedded in, and shaped by social structures. There is an emerging body of work that has sought to take up questions about what to write and how to write as tied up with broader social interests (Aitchison \& Lee, 2006; Badenhorst et al., 20I5; Barnacle \& Dall'Alba, 20I4; Burford, 20I7; Dall'Alba \& Barnacle, 2007; Frick, 2019; Grant, 2005; Grant \& Knowles, 2000; Guerin, 2016; Kamler \& Thomson, 2008, 20I4; Lillis, 200I; Starke-Meyerring, 20II; Starke-Meyerring et al., 20I4). In this chapter, I extend work that approaches doctoral writing as a social and discursive practice that is politically implicated (Burford, 20I7). In particular, I wish to pay more attention to the discourses surrounding the doctoral dissertation, prompted by the rise of Ph.D.s by publication, particularly within the humanities and social sciences.

My theoretical framework relies on a critical discourse analytical approach that investigates language in use in specific contexts-in this case, language around the thesis (Gee, 20II, 20I4a). This language around the thesis genre might also be understood as an example of what Jane Giltrow (2002) has called metagenre- - "situated language about situated language" (p. 19o). Despite a widespread and increasing interest in new materialist research methodologies within educational research, which are explicitly anti-discourse (Kelly, 20I7; Petersen, 20I8; see also Ingram, Chapter I3, this collection), I argue that discourse analysis still has an important role to play in acknowledging language as a performative practice that defines and frames social reality in certain ways. When language is understood not just as a description of reality but also as an act that frames and offers some ways of doing, being, and saying-but not others-it matters (Biesta, 2004). In this chapter, I analyze the language used to describe and legitimize the thesis and how $\mathrm{Ph} . \mathrm{D}$. super-

1 Throughout this chapter, I will use the terms thesis and dissertation interchangeably. 
visors and doctoral candidates use language to communicate certain perspectives that define and frame what is a right, good, or relevant choice of thesis format. Within a critical discourse analytical approach, the term discourse is used to describe discourses as "socially accepted associations" or "ways of using language, of thinking, valuing, acting, and interacting, in the 'right' places and at the 'right' times with the 'right' object" (Gee, 20I4a, pp. 51-52).

\section{This Study}

The analysis undertaken in this chapter is based on a larger research project I undertook for my Ph.D. project between 20I4 and 20I9. It took place at two research universities in Denmark. Data were generated from thirteen qualitative semi-structured interviews with Ph.D. supervisors and doctoral candidates in the social sciences and humanities, each lasting approximately 90 minutes (Skov, 20r9). Although supervisors and candidates were not related to each other in a supervisory relationship, this suited my purposes because it was not the supervisor relationship I wished to investigate. Instead, I was interested in the perspectives Ph.D. supervisors and doctoral candidates held regarding the thesis and saw the supervisors and candidates as important stakeholders whose views ought to be consulted. Using contact information gleaned from institutional websites, I emailed and recruited supervisors and doctoral candidates of different ages and genders, supervisors with varying degrees of experience, and doctoral candidates at various stages in their doctoral studies. A total of seven candidates and six supervisors participated. Of the candidates, four were female and three were male. Of the supervisors, three were female and three were male. The findings of this exploratory qualitative study were not intended to be generalizable. Rather, the aim of this study and participant selection was to elicit multiple emic perspectives in order to better access complex and nuanced decision-making processes regarding thesis formats. I intentionally recruited participants from two different universities (seven from one and six from the other) because I wanted to explore whether there might be patterns in the ways thesis writing was imagined by various stakeholders. Both universities had the same policy framework for thesis formats and examination.

I used a sociolinguistic approach to aid me with my analysis. Such an approach gives researchers the tools and permission to focus not only on what is said but also on how and by whom it is said (Gee, 20I4b; Lee, 1994). In the next section, I unfold the two dominant discourses (instrumental and intellectual) I found were heavily drawn on by supervisors and doctoral candidates to argue for and legitimize their choices with regards to thesis formats (Skov, 2org). 


\section{An Intellectual Discourse and an Instrumental Discourse}

In this section, I discuss what characterizes instrumental and intellectual discourses. Within an instrumental discourse, the thesis is constructed primarily as a product, detached from the specific practice of research. The thesis is described alongside words like number, excellence, relevance, competency, completion, status, return on investment, and visibility. In addition, the thesis is described in relationship to how it contributes to the performance of either the individual doctoral candidate or the institution. Conversely, within an intellectual discourse the thesis is constructed as a specific practice of research meaningful in itself and as both a process and a product. The thesis is described alongside words like scholarship, depth, knowledge production, and intellectual enterprise. In addition, within intellectual discourse the thesis is described in relationship to how it develops and contributes to knowledge and discourse communities. It is important to clarify that these discourses are not to be understood as opposites on a continuum-even though to a large extent they are constituted and defined by how they exclude or other each other-because they also overlap in some areas. For instance, both are oriented towards thesis writing as a product and as a means that can help researchers gain status or even enhance their career.

In the following sections I share my analysis of interview excerpts, paying particular attention to the complex and varying ways that language is used to argue for and legitimize choice of thesis format. ${ }^{2}$ I show how the two dominant discourses, the intellectual discourse and the instrumental discourse, work to construct the thesis in somewhat contradictory ways.

\section{Thesis Writing as Fulfilling Standards}

The following excerpt is from an interview with a doctoral candidate studying in the humanities. In it, he shares his thoughts regarding the multiple decision points he faced when deciding which thesis format to use. At first, he wanted to write a monograph, but he later decided to write a Ph.D. by publication. Here, I asked him whose idea it was to write a monograph in the first place:

Well, it wasn't my idea. It was my supervisor who thought that the monograph-way of writing would be a good idea,

2 As mentioned, my data collection took place within a Danish context and consisted of interviews with Danish supervisors and doctoral candidates; therefore, the analysis presented in this chapter is an analysis of Danish language. In the quotations from participants, words written in brackets are my additions in order to make the statements and formulations understandable in English. 
because this was the way she usually did her writing. I don't remember us having a talk about which format to choose, what the pros and cons were. I don't think it was because she didn't want to have this talk.

In this explanation, the student rationalized the choice of the monograph with regard to tradition, with the supervisor as a stand-in for a tradition. This tradition was not articulated in specifics or connected to specific research practices; instead, the candidate talked about it in general terms as being "a good idea" and legitimized it by referring to it as something that the supervisor was used to.

The candidate was very confused about what was expected of him with regards to writing a thesis, and in trying to make things easier for himself, he chose to write a Ph.D. by publication instead of a monograph, feeling that the Ph.D. by publication provided explicit criteria and standards that he could identify and fulfill. He described these criteria as follows:

For instance, in relation to [lowering] my ambitions, there is the question of the number of articles (in the Ph.D. by publication) and whether I should choose to write four or only three. [Then] there is the question of looking at journals figuring out in which of these it will be possible for me to get my article published with in a specific time frame... . There are many different quality criteria that one can put forward. My approach is, well, if the article gets accepted [by the journal], then it is cool, or then I am like "home free" in some way. Whereas my supervisor perhaps has some ambitions that go a little bit further-if I can put it like this.

In the absence of explicit criteria, this doctoral candidate turned towards the requirements of the $\mathrm{Ph}$.D. by publication, for instance towards the number of articles. Furthermore, he turned towards more general and decontextualized criteria regarding articles as being "good enough," based solely on acceptance in a journal. As evidenced in the above quotation, the supervisor was not a part of the candidate's process of finding out and understanding the requirements of different thesis formats. The candidate constructed the "supervisor" as a somewhat disappointed expert with ambitions that "go a little bit further" than just getting published, but these ambitions were not made explicit or discussed. Apparently, for this supervisor there were some more substantial ideas about quality of work that frame article writing, hence the Ph.D. by publication. I will return to explore these ideas more fully in just a moment. 
This Ph.D. candidate drew strategically on instrumental discourses in his talk about the thesis, knowing that there were also other discourses available in the construction of the thesis. Thesis writing became, within this instrumental universe, a question of numbers ("four or only three" articles), a question of fulfilling standards ("if the article gets accepted ... then I am, like, 'home free"'), and, as he expressed earlier in the interview, a question of saving time ("writing three instead for four articles will save me a lot of time") as well as a question of career and the exchange of goods ("the more you publish, the more attractive you are within this system"). In my data, participants who used instrumental discourses to justify their choices tended to frame the Ph.D. by publication in instrumental ways. As I will show next, they used terms like completion, results, competency, career, status, and statistics to describe this thesis format, constructing the thesis primarily as a means to an end. The Ph.D. by publication was also often described as a product and in terms of its benefits. Phrases such as "return on investment" were used to foreground how the Ph.D. by publication "benefited" doctoral writers and institutions, which led me to wonder whether the monograph format may be having difficulties in being considered relevant, beneficial, and legitimate. I elaborate on this further in the following section.

\section{The Monograph Thesis: Difficulties in Recognizing It as a Legitimate Format}

The next excerpt from a social science doctoral candidate shows how considering the way in which the thesis will be used outside of academia was used to justify proceeding with a manuscript-based thesis format. Right before this excerpt, the candidate had been speaking about his $\mathrm{Ph} . \mathrm{D}$. project and how he thought it was a shame that it had to be written in a $\mathrm{Ph}$.D. by publication format - with no place for "context," "nuance," or "history," as he put it-instead of a monograph, which, although he originally preferred it, was not a tradition within his field. To legitimize not writing a monograph after all, the candidate recounted one of his priorities: the broader dissemination of his research, suggesting that this is something doctoral candidates are obliged to do given the fact that the Ph.D. is "expensive":

This is also about the result; it is about the Ph.D. project being utilized outside, because I think in justifying spend-

3 The Ph.D. candidature in Denmark is a three-year fully-funded position with conditions equivalent to a full-time academic position (paid vacation, superannuation, etc.) and currently costs around 150.000 EUROs (Uddannelses- og Forskningsministeriet, 2017b). 
ing a lot of money on getting doctoral candidates through these systems, then I think we should have some discussion of what it is that we are doing.

In our discussion, the candidate spoke about the thesis as something that ought to be a return on an investment, and he discussed writing articles (as part of the Ph.D. by publication) as something that makes this possible. At the same time, he described the monograph thesis as a less relevant format in a context where the Ph.D. is understood in terms of costs and benefits. Similarly, he positioned himself as a subject who needed to get "through these systems" in order to be cost efficient or as needing to repay a debt of sorts. He also introduced the "inside versus outside" the academy dichotomy. This candidate expressed the assumption that the results and outcomes of a given research project are worth more if they target audiences and structures outside the academy.

Besides being mentioned together with words like context, nuance, or history, in my study the monograph thesis was also articulated together with words like depth, substance, consistency, and argumentation. One supervisor within social science described the monograph as characterized by "requiring scientific consistency" and "an opportunity for working in-depth." Another supervisor within the humanities talked about writing a monograph as a certain way of knowing, stating, "I think you are being forced to do certain kinds of cognitive processes. To do a coherent piece of work pushes you to places where you can reconsider stuff." Though the monograph thesis in my data was most often represented using an intellectual discourse among both supervisors and candidates, the following excerpt from a Ph.D. supervisor within the social sciences highlights how an instrumental discourse is activated when arguing for the relevance of the format:

It is highly impressive if the candidate can show that she or he also are $[\mathrm{sic}]$ capable of working in depth. If the candidate only has produced articles, then one could ask: Is the candidate also capable of more comprehensive [work]? These tendencies [of prioritizing an ability to work in depth] are somehow coming from the United States ... [where] it counts for something if you can produce the big narrative as well.... If over time the candidate is expected to write monographs with major publishers, then he or she must also be able to show the capacity to write something that is coherent.

The supervisor referred to ability, labour market needs, and employer interests as well as to the United States and major publishers as convincing evidence 
for pursuing the book-length (monograph) format. In other words, the supervisor legitimized the monograph format by drawing on an instrumental discourse that constructed the thesis as a means to an end-that is, as a means for developing certain competencies, particularly with regards to an ability to work in-depth and produce "big narratives." Furthermore, the supervisor legitimized monograph-competencies by referring to them as "coming from the United States" and in the interests of the "major publishers." It seemed difficult for the supervisor to argue for the legitimacy of the monograph thesis without drawing on an instrumental discourse.

The instrumental context shown and articulated in my material indicates the monograph thesis is something that candidates write in opposition-the monograph is something candidates do "in spite of." A supervisor within the humanities articulated this very point by referring to one of his own candidates who had chosen to write a monograph. He paraphrased this candidate as saying: "No, damn, I am doing it anyway." In this case, writing a monograph was something the candidate chose to do "anyway," as if it were a format that took courage and determination to choose - traits which, interestingly, also happen to be regarded as important attributes for researchers to have. Similarly, a candidate within the social sciences shared the following comments regarding her decision for choosing the monograph format:

So, in the end, I decided to put away all those expectations [about getting published], and said to myself: First and foremost, I am supposed to produce an excellent Ph.D. and my masterpiece is the monograph. If afterwards, I will be able to write some articles on the basis of that, it would be super. So, it is myself who has had to come to this decision, that this was the way things worked the best for me.

In general, the monograph thesis is, as constructed here, a format that is difficult to find legitimate intellectual arguments for-thus, it is a format that candidates need determination to pursue. The Ph.D. candidate in this example turned inward to argue for her decision to write a monograph, saying that "this was the way things worked best for me."

\section{Thesis Writing as Research or as Performance}

In the next example, taken from an interview with a doctoral candidate in the humanities, the speaker reflected on one of the pros of writing a Ph.D. by publication - that it gives the doctoral candidate some publications to include on a resume. Despite this, she decided to pursue a monograph format. 
When asked whether she thought it was a problem she had not written any articles, she replied,

Yes and no. If I want to apply for a post-doc, that is, if I want to stay in academia, then I think it would be better if I had some publications that I could write on my resume.... And also, I am thinking about the community, that I would like to contribute to the metrics that my department is measured by. I would like this feeling of all us collectively doing something good for the department, for instance if it helps that I appear in Deadline [a Danish television program] three times ... and the same goes for those articles. When my head of department is negotiating with whomever he is negotiating with, if there are some statistics of how many articles that are published here and there, then I would have liked if I had been able to contribute to those statistics. If I had just been able to, but then again, this was not how things went.

In this example, she imagined the $\mathrm{Ph} . \mathrm{D}$. by publication using an instrumental discourse, a discource in which the thesis is seen as having potential to boost resumes, careers, and the performance of the institution. In addition, in this interview, other traditional academic values and practices gained new meanings. For instance, this candidate understood "the community" not only in its more traditional sense as a community of researchers but also as a community of performers, that is, people working together to enhance this community's performance. And by extension, she understood the "contribution" traditionally associated with the thesis not solely as a contribution to knowledge or to the disciplines but also as a contribution to the performance of a particular department. This candidate, then, imbued the monograph thesis with guilt because she did not associate it with a sense of contributing to her department.

This candidate decided to write a monograph - a selfish decision she perhaps felt guilty about because contributing to departmental metrics was, for her, something for which Ph.D. candidates and researchers ought to be responsible. It seems for her it was impossible for doctoral candidates to address or honor both discourses in their writing: writing in the interest of producing knowledge (the intellectual discourse) or writing in the interest of contributing to institutional research performance (the instrumental discourse). It seems for her there was a gap between instrumental discourses, which imagine thesis writing in terms of products, deliveries, numbers, research metrics, and visibility, and intellectual discourses, which imagine thesis writing 
in terms of transformation and production of knowledge, contribution to the discipline, discourse communities, and society.

As mentioned, among doctoral candidates, the $\mathrm{Ph} . \mathrm{D}$. by publication was, to a large extent, articulated using instrumental rationales. This does not mean that candidates did not sense an intellectual discourse-indeed, they seemed very aware of their supervisors' inclination to represent both the monograph and the Ph.D. by publication in terms of their epistemological potentials and different capacities as ways of knowing. This was thematised in the following quotation from a supervisor within the humanities who talked about "the book" as an important format as compared to the article as a format:

When writing a book, you are confronted with a problem which you don't meet when you are writing an article-and that is the fundamental architectural problem: How to build up an argument, a substantial argument. And this problem brings you one step further down in the substance of the subject matter.... When you build up a book, there are some basic choices you have to make which are substantial and important, and this hurts.

In this rationalization, the supervisor drew on intellectual understandings in the sense that he talked about the book format as a specific research practice, not only as a means to achieve something else. For him, writing a book was a specific way of producing knowledge, a specific way of knowing, and it "hurts." Furthermore, he repeated the word "problem" three times, constructing research writing also around this feature. When I asked him if, in his opinion, it was better to write a monograph rather than a Ph.D. by publication, he confirmed, but then afterwards he talked about how articles "might offer and enable other ways of knowing," for instance in "addressing an international audience." In this sense, he also constructed the Ph.D. by publication (not only the monograph thesis) within an intellectual discourse, putting epistemological concerns in the center when talking about research writing. However, besides drawing on an intellectual discourse when talking about the thesis (in both formats), supervisors in this project also drew on and activated instrumental rationales when legitimating their own writing practices. This is what the next section is about.

\section{It's Difficult Not to Become Instrumental}

In the following excerpt, a humanities supervisor discussed his own research writing. He mentioned writing a book and how he was enjoying it—but, he 
added, he also wrote articles, "of course":

As a researcher you can't write a book without reconsidering stuff. There was something-uh-it was important for me to write a book. And the next thing I will be doing, is that I will write-I write a lot of articles of course, I write articles all the time- but I am working towards another book, I think it is fun to write books.

This supervisor mentioned writing in long formats, together with the terms "reconsidering," "important," and "fun"- and this type of writing was articulated as a personal matter, something "I" found important or "I" thought was fun. This was different from how he discussed his writing of articles, which was in terms of number and frequency ("a lot," "all the time") and with the use of the adverb "of course," which builds on an agreed assumption that being a researcher means writing articles. In such articulation, the supervisor constructed a reality where writing a book was not in itself sufficiently valuable- even though he also constructed it as plural ("another book"). Writing was only legitimate when producing articles as well-measured numerically.

Another supervisor, this time in the social sciences, described having difficulties with not relying on instrumental discourses when advising doctoral candidates:

If the candidates choose to write a monograph, then I regularly talk with them about which writing tasks can be parked [returned to after completion]. I tell them that they have a whole life afterwards for writing articles. And I talk to them about which writing tasks could easily be done now, or which make sense writing together with others or me.

This supervisor talked about writing articles as a task that could be "parked," completed fairly "easily," or achieved by "writing together with others." This supervisor seemed to suggest that it was not possible for candidates to engage in both writing articles and writing a monograph during their candidature.

The same instrumental way of talking about research writing, detached from substance, was displayed when a supervisor within the humanities mentioned how he himself only wrote books to be published at "the major publishers." In highlighting this, he constructed a reality where quality was articulated together with size and status. Similarly, a social sciences supervisor told me how he only read articles from "the best journals." These examples display how the instrumental discourse is an important meaning making resource within research environments. 


\section{Thesis Writing Imagined Through an Instrumental Discourse}

In this study, I have investigated how the Ph.D. by publication has become more prevalent within the humanities and social sciences during the last couple of decades by analyzing how local stakeholders within doctoral education legitimize their choice of format. As such, I have extended extant conversations about the Ph.D. by publication by offering a description of how the thesis is imagined most often using an instrumental discourse that emphasizes what it does for individuals or institutions rather than what it does for disciplines and knowledge, as older conceptions of the $\mathrm{Ph} . \mathrm{D}$. emphasized (Barnacle, 20I8; Kelly, 20I7). In this instrumental context, my analysis indicates the $\mathrm{Ph}$.D. by publication is frequently articulated by doctoral candidates as the most relevant format, and by "relevant," the doctoral candidates seem to mean that the format contributes to their performance by helping them, for instance, increase numbers of published articles, improve their resumes, enhance career opportunities, and ease the way to degree completion. Within this context, the monograph thesis seems to be taking a backseat to the manuscript format, possibly because it can not compete in the same instrumental terms (e.g., in terms of numbers, productivity, resumes, etc.).

Although the Ph.D. by publication as a format may not in itself contribute to the instrumentalizing of writing within doctoral education, my research shows that this format is articulated together with instrumental ideas and understandings of research writing more often than the monograph thesis. Frances Kelly wrote, with reference to Charles Taylor, that "new practices only make sense according to the new 'outlook' or idea — this idea then provides the context in which the practices make sense" (20I7, p. 9). My research shows that the Ph.D. by publication, as a practice, makes it possible to talk about research writing in terms of products, numbers, visibility, productivity, and the fulfilling of certain standards in ways the monograph format does not seem to. Instrumental discourse is not especially concerned about research writing as a specific practice but only as a means to something else, decontextualized from the specific knowledge-producing activity to which it relates. Intellectual discourse, on the other hand, imagines and constructs thesis writing as an intellectual endeavor, as a process of inquiry, and as knowledge transformation, and it constructs the value of the thesis in terms of how it contributes to knowledge and disciplines. Portraying the thesis in somewhat contradictory terms reveals what Robyn Barnacle (2018), with reference to William Clark (2006), described as "an underlying tension in contemporary discourse on the Ph.D. between an 
instrumental conception, in which the $\mathrm{Ph}$. D . is seen primarily in the service of knowledge societies and economic and social prosperity, and an older conception in which the value of the Ph.D. is located in the service of the disciplines, truth and knowledge" (p. 78 ).

What this all seems to suggest is that language, in this case language around the thesis, is a productive and performative practice that opens up and closes down certain possibilities when it comes to making a decision regarding the format for the thesis (Lee \& Green, 2009). This suggestion has implications for doctoral candidates. With instrumental and intellectual discourses at work, thesis writing is filled with contradictory expectations for doctoral candidates; should they write for the sake of knowledge production in its own right or for the sake of performing productivity, competencies, and value for future employers? My study shows doctoral candidates caught between these expectations and sometimes feeling guilty that they cannot meet both expectations. It also shows that it is difficult for both candidates and supervisors not to become instrumental, legitimizing their research writing by referring to what it does for their career development, personal and institutional research performance, etc. As shown, the intellectual way of talking and making sense does not seem to be sufficiently convincing when candidates and supervisors argue for and legitimize their research writing.

\section{References}

Aitchison, C., Catterall, J., Ross, P., \& Burgin, S. (2012). 'Tough love and tears':

Learning doctoral writing in the sciences. Higher Education Research E Development, 31(4), 435-447. https://doi.org/10.1080/07294360.2011.559195

Aitchison, C. \& Lee, A. (2006). Research writing: Problems and pedagogies. Teaching in Higher Education, 11(3), 265-278. https://doi. org/10.1080/13562510600680574

Badenhorst, C., Moloney, C., Rosales, J., Dyer, J. \& Ru, L. (2015). Beyond deficit: Graduate student research-writing pedagogies. Teaching in Higher Education, 20(1), 1-11. https://doi.org/10.1080/13562517.2014.945160

Barnacle, R. (2005). Research education ontologies: Exploring doctoral becoming. Higher Education Research E Development, 24(2), 179-188. https://doi. org/10.1080/07294360500062995

Barnacle, R. (2018). Research education and care: The care-full PhD. In S. S. E. Bengtsen, \& R. Barnett (Eds.), The thinking university: A philosophical examination of thought and higher education (pp. 77-86). Springer International Publishing. https://doi.org/10.1007/978-3-319-77667-5_6

Barnacle, R., \& Dall'Alba, G. (2014). Beyond skills: Embodying writerly practices through the doctorate. Studies in Higher Education, 39(7), 1139-1149. https://doi. 
org/10.1080/03075079.2013.777405

Biesta, G. (2004). Against learning: Reclaiming a language for education in an age of learning. Nordisk Pedagogik, 24, 70-82.

Boud, D., \& Lee, A. (Eds.) (2009). Changing practices of doctoral education. Routledge. https://doi.org/10.4324/9780203870488

Burford, J. (2017). Conceptualising doctoral writing as an affective-political practice. International Journal of Doctoral Studies, 12, 17-32. https://doi.org/10.28945/3689

Dall'Alba, G., \& Barnacle, R. (2007). An ontological turn for higher education. Studies in Higher Education, 32(6), 679-691. https://doi. org/10.1080/03075070701685130

Davies, B., \& Petersen, E. B. (2005). Neo-liberal discourse in the Academy: The forestalling of (collective) resistance. LATISS - Learning and Teaching in the Social Sciences, 2(2), 77-98.

de Lange, T. (2013). Stykket og helt: Erfaringer fra det å skrive en artikkelbasert avhandling. Uniped, 36(4), 20-31. https://doi.org/10.3402/uniped.v36i4.23090

Frick, L. (2019). PhD by publication-Panacea or paralysis? Africa Education Review, 16(5), 47-59. https://doi.org/10.1080/18146627.2017.1340802

Gee, J. P. (2011). Discourse analysis: What makes it critical? In R. Rogers (Ed.), An introduction to critical discourse analysis in education (2nd ed.) (pp. 23-45). Routledge.

Gee, J. P. (2014a). An introduction to discourse analysis: Theory and method. Routledge. https://doi.org/10.4324/9781315819679

Gee, J. P. (2014b). How to do discourse analysis: A toolkit (2nd. ed.). Routledge. https:// doi.org/10.4324/9781315819662

Giltrow, J. (2002). Meta-Genre. In R. Coe, L. Lingard, \& T. Teslenko (Eds.), The rhetoric and ideology of genre: Strategies for stability and change (pp. 187-205). Hampton Press.

Grant, B., \& Knowles, S. (2000). Flights of imagination: Academic women be(com) ing writers. International Journal for Academic Development, 5(1), 6-19. https://doi. org/10.1080/136014400410060

Grant, B. M. (2005). Fighting for space in supervision: Fantasies, fairytales, fictions and fallacies. International Journal of Qualitative Studies in Education, 18(3), 337354. https://doi.org/10.1080/09518390500082483

Guerin, C. (2016). Connecting the dots: Writing a doctoral thesis by publication. In C. Badenhorst, \& C. Guerin (Eds.), Research literacies and writing pedagogies for masters and doctoral writers, pp. 31-50. Brill. https://doi. org/10.1163/9789004304338_003

Herrmann, K. J., Wichmann-Hansen, G., \& Jensen, T. K. (2013). Kvalitet i Ph.d.forløb. En undersøgelse blandt ph.d.-studerende på Aarbus Universitet. Aarhus: Center for Undervisning og Læring, Aarhus School of Business and Social Sciences, Aarhus Universitet.

Kamler, B., \& Thomson, P. (2008). The failure of dissertation advice books: Toward alternative pedagogies for doctoral writing. Educational Researcher, 37(8), 507-514. https://doi.org/10.3102/0013189X08327390 
Kamler, B., \& Thomson, P. (2014). Helping doctoral students write: Pedagogies for supervision (2nd. ed.) Routledge. https://doi.org/10.4324/9781315813639

Kelly, F. (2017). The idea of the PhD: The doctorate in the twenty-first-century imagination. Routledge. https://doi.org/10.4324/9781315707396

Lee, A. (1994). Gender and text in educational research. Australian Educational Researcher, 21(3), 25-46. https://doi.org/10.1007/BF03219573

Lee, A., \& Green, B. (2009). Supervision as metaphor. Studies in Higher Education, 34(6), 615-630. https://doi.org/10.1080/03075070802597168

Lillis, T. (2001). Student writing: Access, regulation, desire. Routledge. https://doi. org/10.4324/9780203186268

Manathunga, C. (2019). 'Timescapes' in doctoral education: The politics of temporal equity in higher education. Higher Education Research \& Development, 38(6), 1227-1239. https://doi.org/10.1080/07294360.2019.1629880

Petersen, E. B. (2018). 'Data found us': A critique of some new materialist tropes in educational research. Research in Education, 101(1), 5-16. https://doi. org/10.1177/0034523718792161

Shore, C., \& Wright, S. (2016). Neoliberalisation and the "death of the public university." Anuac 5(1), 46-50. https://doi.org/10.7340/anuac2239-625X-2451

Skov, S. (2019). Hvad er en ph.d.-afhandling? En undersogelse af hvordan ph.d.-afhandlingen konstitueres af ph.d.-vejledere og ph.d.-studerende inden for humaniora og samfundsvidenskab [Doctoral dissertation, Roskilde University]. Roskilde University Research Portal. https://forskning.ruc.dk/files/66325232/20200107_Signe_Skov_ph.d_afhandling_elektronisk_version_FINAL_21.pdf

Starke-Meyerring, D. (2011). The paradox of writing in doctoral education: Student experiences. In L. McAlpine \& C. Amundsen (Eds.), Doctoral education: Research based strategies for doctoral candidates, supervisors and administrators (pp. 75-95). Springer. https://doi.org/10.1007/978-94-007-0507-4_5

Starke-Meyerring, D., Paré, A., Sun, K. Y., \& El-Bezre, N. (2014). Probing normalized institutional discourses about writing: The case of the doctoral thesis. Journal of Academic Language E Learning, 8(2), A13-A27. https://journal.aall.org. au/index.php/jall/article/view/295

Uddannelses- og Forskningsministeriet (2013). Bekendtgørelse om ph.d.-uddannelsen ved universiteterne og visse kunstneriske uddannelsesinstitutioner (ph.d.-bekendtgørelsen). https://www.retsinformation.dk/eli/lta/2013/1039

Uddannelses- og Forskningsministeriet (2017a). Kvalitet i ph.d.-uddannelsen. Spørgeskemaundersøgelse blandt ph.d.-studerende og ph.d.-vejledere. https://ufm. $\mathrm{dk} /$ publikationer/2017/filer/kvalitet-i-phd-uddannelsen-sporgeskemaundersogelse-blandt-phd-studerende-og-phd-vejledere.pdf

Uddannelses- og Forskningsministeriet (2017b). Ph.d.-uddannelsens kvalitet og relevans. Sammenskrivning af hovedresultater. https://ufm.dk/publikationer/2017/ filer/ph-d-uddannelsens-kvalitet-og-relevans.pdf 


\section{Section Two. Concepts and Tensions of Doctoral Writing}





\title{
Borders and Tensions in the Context of Doctoral Writing
}

\author{
Susan van Schalkwyk and Cecilia Jacobs \\ Stelleniosch University, South Africa
}

Abstract: Writing is fundamental to the doctoral journey. It is the means through which the doctoral student demonstrates the extent to which the work that has been undertaken has merit. Navigating the journey towards doctorateness is characterized by a process of identity development as the student transitions into a chosen disciplinary community—a community that is defined by a set of norms and values and by what constitutes knowledge within it. The notion of border crossing provides a lens through which the transition can be explored. Doctoral writing represents a specific border that students encounter as they seek to inscribe their work and look to become powerful writers in their field. Borders are important as they play a role in maintaining the integrity of the discipline, but they can also serve as sites of tension between student and supervisor. In this chapter, we explore the concepts of borders and tensions in the context of re-imagining doctoral writing, offering a voice "from the South." Building on the work in the field of new literacy studies and more recent academic literacies research, we foreground writing as a social practice, emphasising how writing in academic disciplines has a tacit dimension that needs to be made overt. We argue that collaborative approaches to supervision and the adoption of a cohort model, both of which foster a social practices approach to learning, might facilitate border crossing while alleviating sites of tension.

The journey towards "doctorateness" can be associated with the notion of border crossing. Conceptually, border crossing speaks to the idea of political frontiers, whether material or perceptual, and focusses on the identity work that occurs at these frontiers (Prokkola, 2009; van Schalkwyk \& McMillan, 20I6), echoing thoughts of the doctoral experience as being a rite of passage (Andresen, 2000). As doctoral students navigate their academic journeys and seek to cross into their chosen disciplinary communities, they are engaged in a process of identity development within these communities (Inouye \& McAlpine, 2019). Borders are important for disciplines, as they maintain the 
integrity of what is within the discipline and define what constitutes knowledge within the field. They can, however, also be sites of tension, contestation, and resistance, not only in terms of geography, but also in terms of communities, professions, science, and knowledge (Lamont \& Molnár, 2002; see Cox et al., Chapter 7 , this collection). They can exclude and alienate, creating insiders and outsiders. They define not only who belongs but also who does not.

Doctoral writing represents a specific border that students have to negotiate as they seek to inscribe the body of work emerging from their academic endeavours and ultimately become powerful writers themselves. The doctoral student becomes a powerful writer by developing an argument, having an opinion, taking a stand, and, ultimately, by contributing to a body of knowledge. Having an opinion in an academic context "is constructed out of scholarship, which involves examining the work of authorities and building a case that is personally meaningful out of their work and one's own research" (Boughey, 2005, p. 645). Such scholarship is demonstrated, most typically, in the doctoral thesis. Writing is therefore an important medium through which meaning is made, ultimately enabling the doctoral writer to contribute to a body of knowledge in the field. The written text also serves as evidence of the intricacies of the student's thinking, the criticality of their reasoning, and the rigour of their research, which experts, such as supervisors or examiners, are required to review.

In this chapter, we explore borders and tensions in the context of doctoral writing, specifically seeking to articulate a voice "from the South" that takes into account the contextual issues of the South and that draws on research in the South for the South. We seek to bring research from the South into dialogue with research from the North, as the uncritical appropriation of knowledge bases emanating from the North into a context such as South Africa might be quite limiting. Brenda Leibowitz (2012) has advocated for such work, emphasising that in the South, "conditions are different and the particular experience of struggle against injustice and for equality and human flourishing takes on forms which may differ in terms of both content and intensity, from forms in the developed world" (p. xviii). We explore these issues by drawing on our South African roots, our shared background in academic literacies studies (see Jacobs, 2005, 2007, 2010, 20I5; van Schalkwyk, 2007, 2016; van Schalkwyk et al., 2009), and recent work around the question of knowledge (Jacobs, 2013, 2019). We further argue that the process of supervision involves border crossing for doctoral students and "border maintenance" for supervisors, setting up sites of tension for the student writer and between the student writer and the supervisor. We offer the idea of a "cohort approach" to supervision as an alternative to apprenticeship models of supervision and suggest that the cohort approach is one way supervisors can facilitate doctoral border crossings. In addition, we 
describe some of the theoretical positions that help us to understand these sites of tension and highlight work that offers approaches to address them as we join the call for the re-imagining of doctoral writing.

\section{Thoughts on the South African Context}

Before we foreground some of the tensions that manifest in the doctoral writing space, some contextualisation is required. The space within which doctoral work occurs is multi-facetted and, as alluded to in the introduction to this book, under pressure. Doctoral students the world over are highly sought after, particularly in countries where funding models incentivise increased numbers of enrolments in these programmes. The doctorate not only stands as a marker for significant academic achievement, it is also often claimed as an indicator of economic progress at national and international levels (Maistry, 20I7). In South Africa, given its colonial and apartheid history that saw the implementation of an oppressive political and social system of structural inequality, the pressure mentioned above has manifested in different ways. The higher education sector is characterized by considerable unevenness across its 23 public institutions, and few private institutions exist to offer degrees at the doctoral level. Many of South Africa's public institutions lack research infrastructure, often as a result of being restricted in terms of their postgraduate offerings during the apartheid era (McKenna, 20I9a). At the same time, according to South Africa's Department of Higher Education and Training ([DHET] 2019), national targets and incentives saw the numbers of doctoral graduates more than double between 2010 and 2018 (from approximately 1420 to over 3300). Supervisory capacity, however, did not keep pace with the resultant growing numbers of doctoral students entering the system. In addition, the DHET report showed more than 35 percent of doctoral candidates were themselves academics, with fewer than 50 percent of all full-time academic staff holding Ph.D.s. In many environments, this has led to significant pressure being placed on academic staff to take on students irrespective of the extent of their experience or readiness for the role (Maistry, 20I7). The weight of this responsibility is exacerbated by the adoption of the resource-intensive apprenticeship model of supervision-which could be regarded as a colonial legacy - that still dominates in the country (McKenna, 20Igb). An alternative to this apprenticeship model of supervision is the notion of a cohort approach, which will be discussed in greater detail later in this chapter. In a review of the state of doctoral studies in South Africa, Yusef Waghid (20I5) cautioned that the current pressure being placed on institutions and, therefore, supervisors to increase throughput rates represents an "epistemological threat" to the field that could see doctoral education being trivialized (p. 6). 
A further complexity resides in the issue of language. Language is not neutral. In South Africa, language has a powerful presence. While the country's II official languages pay tribute to our rich diversity, they sit uncomfortably alongside one another in our unequal society "representing both freedom and oppression depending on which language and who is speaking ... language becomes a weapon of powerful knowledge, and can serve to subjugate and exclude" (van Schalkwyk, 2or6, p.I48) - much like borders. It is in this contested and uneven space, with often limited resources and sometimes even inadequate supervision, that the doctoral writer seeks to make her mark.

\section{Crossing Borders and Seeking to "Belong"}

Crossing borders can be difficult. It requires negotiation - the identity work noted previously. Graduate students, including doctoral students, come to university with established identities that can have both stature and value in their communities but that may or may not prove to be enabling when they seek entry into a chosen disciplinary community (Canagarajah, 2002). Entry often hinges on the expectation that these students adopt the discourse that dominates the field as well as the entrenched canon that characterises it and that this adoption be represented in their writing. The process is tantamount to learning a new language, one that extends far beyond a lexicon or a set of technical and grammatical rules to define the way in which meaning is made within a particularly disciplinary space and, therefore, the way through which doctoral writers, and indeed their supervisors, contribute to the body of knowledge. Its practices are socially embedded - a concept we will come back to later-and implies a new way of being within the particular field. This field is recognized through having its "own key concepts, truth criteria and forms of life, ... modes of reason and judgement" (Barnett, 2009, p. 239). As a collective, these many dimensions of doctoral writing have been described as a threshold concept-one requiring the learning leap that sees the student making an academic contribution, critically and creatively, through their writing (Wisker \& Savin-Baden, 2009). Learning the requisite language and understanding the values, norms, and conventions that are embedded within is key for emerging doctoral identities, for crossing borders and thresholds, and for doctoral writers (Kamler \& Thompson, 20I4; Wisker \& Savin-Baden, 2009). The choices that students make regarding the words they use and the ways in which they use them are influenced by the conventions of the group or community they align themselves with, which will in turn also inform the extent to which they are seen to "belong."

What does it mean to belong in academia and how does one get to belong? In his work on social learning systems, Etienne Wenger (2000) intro- 
duced the notion of a community of practice, defined by what it regards as competence and where members adopt a joint enterprise or have shared sets of norms, conventions, and ways of interaction. Members of these communities also share a language-much like disciplinary communities. Competence in a community requires understanding the community "well enough to be able to contribute" and engage with it as a "trusted partner," which includes gaining access to a shared "repertoire" and the means to "be able to use it appropriately" (Wenger, 2000, p. 229). Belonging is enabled in three ways: through engagement, imagination, and alignment. These are exciting concepts, as they offer insight into how academia could move forward, which includes considering how novices such as doctoral writers can obtain membership in a disciplinary space and, importantly, how they might potentially influence that space. In essence, these concepts provide an opportunity to re-imagine doctoral writing. Engagement in this context is seen as doing things with others within that community of practice. Imagination refers to a cognitive act of seeing oneself as a member of that community (a reconstruction of an existing identity or the construction of a new identity or identities). Alignment speaks to facilitating a synergy between the new ways of thinking and doing that a newcomer may introduce and the more established practices within the community. Wenger's idea of alignment is central, as in defining it he emphasised that legitimate participation in the community will not exist if newcomers simply adopt an entrenched canon. Former identities need not be shed; rather, "our ability to deal productively with boundaries depends on our ability to engage and suspend our identities ... opening up our identities to other ways of being in the world" (Wenger, 200o, p. 239). It is important to note that the journey towards belonging in the context of doctoral studies is neither seamless nor linear. Instead, as Jazvac-Martek (2009) posited, the progression is incremental, as doctoral students oscillate between being a student and becoming an academic. We would argue that recognising these moments as learning leaps, of increments and of oscillation, has relevance for the supervision of students, particularly in terms of their writing.

\section{Re-imagining Borders}

But who maintains the borders or boundaries Wenger referred to? Who might be, whether intentionally or unintentionally, acting as a gatekeeper; and to what extent is there room for the novice or newcomer to move beyond alignment to a place where they might disrupt or challenge entrenched understandings? What is the potential of a more collaborative cohort approach for enabling "leaky boundaries" and facilitating border crossings? Sue 
Starfield (2004) has suggested that the identity of the student writer often becomes lost in the skewed power relationship that exists between supervisor and student, between expert and novice. The written work of the student becomes "a dialogue between unequal participants" (Starfield, 2004, p. 67), as the discipline-represented by the supervisor, postgraduate review panels, examiners and so forth-determines the boundaries and sets out the borders. "What space is there in this tightly bounded sequence for students to challenge or respond asserting their authority?" asked Starfield (2004, p. 67). The doctoral writer is often trapped into making compromises in their writing in an attempt to sound scholarly and secure entry into the disciplinary community. Lucia Thesen (2013) agreed, highlighting how, in the process of revision, the student's own voice can be erased and therefore silenced, and she described this as a "deeply political issue" asking, what "forms and knowledges are being erased? Why? Who benefits, and who remains silent?" (p. 67)

Given South Africa's history, it is impossible to ignore the powerful socio-political context that informs the debates about doctoral writing and supervision. Supervisors cannot distance themselves from the experience of alienation and exclusion that is very real for many students, particularly doctoral students. Nor can they ignore the hierarchical position that characterises supervisory relationships and how this hierarchy can entrench powerful knowledge boundaries, often in intricate and layered ways. And even if there is opportunity for engagement, even when the supervisory relationship shifts to one that is more collegial and collaborative (Benmore, 20I6), few doctoral students will challenge the disciplinary hegemony that dominates. Few will attempt to "rock the boat" in their doctoral writing. Postgraduate studies, especially at the level of the Ph.D., can be "a very high stakes space to do such 'rocking"' (McKenna, 2oI7a). Picking up on the notion of gatekeeping, Christine Tardy and Paul Kei Matsuda (2009), writing in the context of academic publishing, suggested that "although readers may find certain breaks from convention to be refreshing and thus rhetorically effective, those ruptures generally still have to occur within particular parameters" (p. 45). As large numbers of graduate students drop out or remain "stuck" in the system, the question is to what extent we, whether as supervisors or as post-graduate writing consultants, ${ }^{1}$ are complicit. In focussing our endeavours on strengthening the internal coherence of our disciplines and professions, there is little space for the sort of engagement, imagination, and alignment that Wenger has argued for

1 Writing consultants is a term used in South Africa to refer to practitioners who provide writing support for students. At the doctoral level, such consultants are usually senior writing specialists employed as writing center staff. 
or for the contestation that Starfield referred to. Equally ironic is that even our well-meant efforts to intentionally make overt our expectations with regard to academic writing and the tenets of what scholarship looks like in that field could serve to entrench the power differential between students and supervisors rather than close the gap. In their efforts to hold the integrity of their disciplines and set the boundaries of what constitutes knowledge within their fields, supervisors might inadvertently be silencing students' voices and tightening up the borders rather than respecting their students by creating spaces for a diversity of voices (Doyle et al., 20I8).

Thus far we have explored two broad areas within the context of doctoral writing that could become sites of tension. One area involves the identity of the doctoral student and the border crossing involved in transitioning into their chosen disciplinary community and knowledge domain. The other area involves the supervisor, who traditionally represents the discipline, and her role in maintaining the integrity of the discipline. We have argued that the doctoral journey, which is often defined by the experience of doctoral writing, can be likened to crossing a border and that this metaphor has potential for offering insight into doctoral writers' experiences. We have pointed to the integrity of disciplines and discussed how border maintenance by supervisors could lead to exclusion and alienation for doctoral students as well as contestation between "insiders" and "outsiders." Carolyn Williams and Alison Lee (1999) argued that feelings such as exclusion and alienation should be recognized as dimensions of the Ph.D. experience and are "both a necessary condition and an effect of the production of the subject of doctoral studythe licensed independent scholar" (p. 8).

What, however, does this mean for supervisory practice, and how can the re-imagining of doctoral writing offer a way forward in terms of addressing these tensions? We believe that writing never occurs in a vacuum and that understanding writing as a socially embedded practice, as mentioned earlier, can be of value to this discussion. Michael Samuel and Renuka Vithal (20II) offered as an alternative to the traditional apprenticeship model of supervision a cohort-based model that "draws on the experiences of supervisors, staff, and students as co-producers of knowledge," and they argued that the Ph.D. is not about individualistic learning but rather is about "responsiveness to knowledge production in community" (p. 76). This speaks to a social practices approach to learning that, we would argue, is supported by a collaborative cohort supervision approach. While studies that focus on the experience of doctoral writing at an individual level have provided useful insights into challenges experienced by student writers, they do not shed light on writing as a social practice. Such foregrounding is important (Burford 20I7; Inouye \& 
McAlpine, 20I9). Work conducted several years ago in the field of new literacy studies and more recent academic literacies work from South Africa offer some frameworks with which we can begin to interrogate writing as a social practice and then to consider what this could mean for adopting a cohort approach to supervision.

\section{Writing as a Social Practice}

James Paul Gee (1990), whose work has been seminal in the field of new literacy studies, described socially embedded activities as Discourses and, as we have discussed, disciplinary experts value these Discourses and therefore set a premium on them. Understanding Discourses is crucial for doctoral writers, because this understanding contributes to their development of the sort of disciplinary identity that can inform their thinking and their writing. Access to the Discourse requires successfully crossing borders, as doctoral students never just write; rather, they always write something for someone and always for a specific purpose (Gee, 2008).

Brian Street (1984) had earlier offered two sets of ideas regarding academic literacies: autonomous and ideological literacies. His ideological model of literacy posited that literacy practices, such as writing, are deeply embedded in the ideologies that prevail in society, the paradigms of individual writers, and power relations, such as those that exist between a doctoral student and supervisor. Street strongly opposed the autonomous model, which sees writing as a generic skill, easily transferable from one writing context to another, and often taught independent of a social context. Building on the work of Ron and Suzanne Scollon (198I) and Shirley Brice Heath (1983), he expanded on the notion of multiple literacies, examining how literacies, such as writing, vary across contexts. Relatedly, we've framed this chapter using the ideological model of literacy. In other words, we see writing practices as variable, differing from one social context to another, and from one academic discipline to another.

One of the basic tenets of this theoretical orientation is that writing is always situated within specific social practices and, in the case of higher education, within specific disciplines- thus linking back to our earlier discussion. Accordingly, we would argue that the teaching of doctoral writing should be embedded within the contexts of particular academic disciplines and that doctoral student writers should be developed within the ways in which their particular disciplines use language. This would imply that doctoral students are best inducted into the writing practices of their various disciplines of study by modeling themselves on disciplinary "insiders," such as their supervisors, who ought to have mastered these practices and be a part of these 
disciplinary communities themselves. Gee (1990) argued that supervisors are best placed to induct doctoral students into the writing practices of their disciplines rather than writing courses, which often teach writing practices that exist only in such courses and do not exist anywhere else, either inside or outside of the university. He posited that such writing courses often construct pseudo-Discourses of their own. While we agree with this critique of separate writing courses, one needs to confront the challenges facing supervisors, namely that of making what they already know tacitly about writing in their disciplines available to their doctoral students. We would argue that a more collaborative cohort approach might address this challenge better than the traditional apprenticeship model of supervision.

\section{Making the Tacit Overt}

Theorists in the rhetorical studies tradition (Bazerman, I994; Bazerman et al., 2009; Geisler, 1994; Segal et al., 1998) also proposed a theory of literacy that sees writing as socially constructed and argue that the linguistic resources individuals draw on to produce text are shaped by a lifetime of interaction with others. This proposition is closely aligned to the way that New Literacy Studies scholars understand literacies. However, these theorists from the rhetorical studies tradition went further, arguing that writing in academic disciplines has a tacit dimension, which makes it difficult for supervisors to articulate and therefore difficult for doctoral students to learn. They argued that while disciplinary specialists, such as supervisors, "know" the rhetorical processes through which their disciplines communicate meaning (albeit tacitly), post-graduate writing consultants (who usually come from a language studies background) are better positioned to "see" this largely invisible process because they view writing as opaque since the disciplinary content is often foreign to them-they do not get caught up in the meaning of the work they're interacting with. This makes the generic structures and discursive patterns clearer than when they are obscured by meaning, as is the case with supervisors who tend to view writing as transparent, and look through the generic structures and discursive patterns in order to engage with the disciplinary content.

Supervisors, however, bring a tacit knowledge of their disciplinary genres and Discourses and the purposes they serve in meaning-making. Cheryl Geisler (1994) described this as the "rhetorical dimension" of knowledge, which entails knowing when, where, to whom, and how to communicate the content knowledge in writing (p. 37) — similar to Gee's ideas around Discourse. This knowledge is gained over years of study and participation in disciplinary communities and is a knowledge base that post-graduate writing consultants 
do not have. On the other hand, writing consultants are often better able to see the rhetorical processes underpinning writing. This has led them to take increasing responsibility for making this dimension of doctoral writing explicit for students, which assumes that the consultants have the requisite knowledge of the rhetorical processes underpinning doctoral writing as well. Findings from South African research (Jacobs, 2007), however, have shown that this assumption is flawed and often leads to a pedagogical position that assumes writing consultants know the "rhetorical dimension" (Geisler, I994, p. 37) of doctoral writing better than the supervisors know it themselves. A solution could be a collaborative approach to the development of doctoral writing, one that understands the central role writing plays in how disciplines structure their knowledge bases and how they produce text. There is variability across disciplines, and therefore the approach to the supervision of doctoral writing being advocated by this literature is a collaborative effort between doctoral writing consultants and supervisors (see also Padmanabhan \& Rossetto, 20I7), along with a cohort of doctoral students (Samuel \& Vithal, 20II). However, we would caution against an approach that requires post-graduate writing consultants to deal with subject matter about which they know little by venturing out into disciplinary territory with which they may be unfamiliar or in which they themselves are still novices.

It is through the interaction of supervisors and post-graduate writing consultants that the generic structures and discursive patterns of writing, as well as the purposes they serve in meaning-making, can be critically deconstructed for doctoral students. This collaborative cohort approach has the potential to facilitate the process of border crossing for both doctoral students and their supervisors. However, it is incumbent on supervisors to be deliberate about making overt their expectations regarding academic writing as well as the tenets of what scholarship looks like in their field. This comes with a caveat, as alluded to earlier, that supervisors' well-intentioned efforts at making overt the nature of scholarship in their field could serve to entrench the power differential between supervisors and doctoral students rather than close the gap. We turn to the more recent work of Chrissie Boughey (2013) and Boughey and Sioux McKenna (20I6) to theorise this dilemma.

\section{Powerful Knowledge}

Building on the work of Street (1984) and his autonomous and ideological models, Boughey (2013) and Boughey \& McKenna (2016) have offered two related sets of ideas that are also relevant to understandings of writing as a social practice-individual and social. Boughey (2013) has argued that indi- 
vidualized views of learning (and we would argue "writing") are dominant in South Africa and that such views construct students as independent or autonomous of the social contexts in which they were raised, in which they live, and in which they learn (and write). These understandings have implications for doctoral writing, leading to writing practices that are decontextualized from the disciplinary contexts surrounding doctoral writing. In contrast to this, in a social view of learning (and again we would argue "writing"), supervisors would see students as being shaped by the very contexts in which they were raised, in which they live, and in which they learn (and write). A social view of learning sees doctoral writing as context-dependent, socially constructed, and power ridden-drawing together many of the ideas we have already introduced. This view then calls on us to interrogate the bounded social space surrounding the student-supervisor relationship and examine how the borders and boundaries could serve to include or exclude doctoral students from access to powerful knowledge and from becoming powerful writers themselves.

The relationship between a supervisor and a doctoral student is not neutral or equal. As previously mentioned, supervisors are part of disciplinary communities who have access to powerful knowledge, who understand what scholarship looks like in their disciplines, and who have mastered the writing practices of their fields. Geisler (1994) claimed that the "rhetorical process" underpinning knowledge in disciplines remains hidden for most undergraduate students because they are taught to view texts as "repositories of knowledge, completely explicit in their content but utterly opaque in their rhetorical construction" (p. 39). This claim has implications for doctoral students and their relationships with their supervisors. Since doctoral students are being apprenticed into what Geisler (1994) termed the "rhetorical dimension" (p. 37) of disciplinary knowledge by their supervisors, and since supervisors are focussed on strengthening this aspect in an attempt to produce successfully written doctoral dissertations, the possibility for doctoral students to cross disciplinary borders and challenge or disrupt entrenched rhetorical practices might be diminished. Studies from the sociology of knowledge offer some thoughts on negotiating this tension that doctoral supervisors face.

\section{Negotiating the Tension}

We have previously argued that as experts in their respective fields, supervisors have a role in preserving the established rhetorical practices (or boundaries) of their disciplines. However, doctoral supervisors may also encourage doctoral students to critique these established rhetorical practices and chal- 
lenge the disciplinary hegemony. Herein lies the tension. While a social view of writing calls on us to examine how the student-supervisor relationship might serve to include or exclude doctoral students, studies from the sociology of knowledge suggest ways supervisors can provide access to how powerful knowledge works - its organising principles and the logics around what is considered legitimate knowledge-making practices (Maton \& Moore, 20IO). Karl Maton's (20I4) Legitimation Code Theory offers supervisors a practical toolkit that allows them to make explicit to doctoral students the organising principles, procedures, and practices underpinning how knowledge is produced in their fields, the disciplinary "rules of the academic game," (p. II) as he termed it. Maton also argued that these rules are tacit and that academics (and supervisors) need to make explicit to their students the values, principles, procedures, and practices underpinning how knowledge is produced in their disciplines and how knowledge claims are made - thus echoing what we have already described.

Scholars in rhetorical studies have argued that in order for doctoral students to challenge and disrupt entrenched rhetorical practices, they first need to understand how these practices manifest in doctoral writing. This offers useful insights into the invisible mechanisms that give rise to the different forms of disciplinary knowledge. Legitimation Code Theory takes such insights further by offering practical tools, such as specialization, which examines the underpinning organising principles of disciplines (Clarence $\& \mathrm{McK}$ enna, 20I7) - tools that can be applied to the writing of doctoral students. More recently, Kirstin Wilmot (2020) has extended legitimation code theory by applying conceptual tools, such as the clausing tool, for analysing exemplary knowledge practices in doctoral writing. She used the clausing tool to demonstrate how, in their writing, doctoral students move between raw data and their interpretations of that data by linking to existing knowledge in the field. This work addresses a gap in both the fields of new literacy studies (which focuses on writing practices) and rhetorical studies (which focuses on the linguistic features of texts) and offers both supervisors and post-graduate writing consultants a set of strategies to produce exemplary doctoral writing. These strategies, establishing, characterizing, coordinating, and taxonomizing, which create a bridge between empirical data and theory, can be used by doctoral students to write better dissertations and also by supervisors as pedagogic resources to make doctoral writing practices more explicit. Such a knowledge-based approach to doctoral writing pedagogy might negotiate the border-crossing tension that supervisors face as they try to preserve the established rhetorical practices of their disciplines while also producing doctoral students who are able to critique these established rhetorical practices. 
However, South Africa faces huge resource challenges, as alluded to earlier, and the inclusion of a post-graduate writing consultant into the resource-intensive apprenticeship model of supervision that continues to be the dominant mode in the country might not be tenable (see also Padmanabhan \& Rossetto, 20I7). An alternative to the apprenticeship model of supervision, and one that is being practiced in a number of universities in South Africa, is the cohort model.

\section{A Cohort Model}

The way in which the cohort model is conceptualized and implemented varies according to the particularities of the university context. To demonstrate this variety, we will conclude by briefly discussing two cohort models we've experienced at two different South African universities.

Case one was a seminar-based cohort model involving "students, supervisors and their disciplinary studies in a collaborative dialogue which produces opportunities for disruption, engagement and re-definitions of the doctoral study" (Samuel \& Vithal 20II, p. 79). A feature of this model is that "a collective of supervisors who recognise both their individual strengths and their limitations collaborated, complementing and supplementing each other's knowledge base, and providing a space for a collective of students to come together to think, learn and take risks in crossing disciplinary and methodological borders" (Samuel \& Vithal, 2oIr, p. 79). These students, while having individual supervisors assigned to them, took part in a series of structured seminars. Participation was compulsory. Seminars took place across weekends (Friday to Sunday) every six weeks over a ten-month period for each year of study. The seminar programme involved different groupings-for example, general seminars for the entire doctoral cohort, separate seminars for year one and year two doctoral students, seminars that combined year one and year two doctoral students who were using similar research methodologies, and seminars that combined students who had similar research focus areas. The catalyst for the implementation of this model was a paucity of senior academics who could serve as supervisors. To address this, a group of "newly graduated doctoral staff used their own experience and networks to support each other and the doctoral students as a group" (Samuel \& Vithal, 20II, p. 79).

Case two used a cohort model that combines traditional supervision with a community approach to doctoral education (McKenna, 20I7a). The programme was designed not only to provide peer-group support but also to promote research in a particular focus area. Most of the doctoral students were studying part time, and participation was voluntary. The programme 
supported the "development of the research design, implementation of the research and writing of the dissertation" (McKenna, 20I4, p. 7) and included three week-long meetings a year-which consisted of guest seminars, debates, panel discussions, scholar presentations, and workshops-as well as online synchronous seminars, asynchronous resources, and various groupings of scholars working in project teams and drawing on shared theoretical frameworks. This cohort model provided a supportive community for the students, encouraged students to take risks and test ideas, and provided opportunities for students to articulate their work. One of the catalysts for the implementation of this model was a national drive to increase the production of doctoral graduates and a critique of the traditional apprenticeship model's capacity to deliver this objective.

These cases offer descriptions of what cohort models may look like and insights into the debates and issues surrounding their implementation. By their nature, cohort models are collaborative, and as these cases illustrate, they facilitate border crossing and foster a social practices approach to learning. How then, could the notion of a cohort model enable the re-imagining of doctoral writing?

\section{Re-imagining Doctoral Writing}

We have argued that it is incumbent on supervisors to re-imagine doctoral writing and that their process of re-imagining might be enabled by collaborating with stakeholders involved in the doctoral enterprise, such as post-graduate writing consultants and doctoral students, as well as a knowledge-based approach to doctoral writing practice and pedagogy. Such a model spreads resources, such as supervisors and post-graduate writing consultants, across a cohort of doctoral students. This brings the added benefit of each individual student having access to the collective thinking of a group of doctoral students as well as each supervisor having access to the collective expertise of a group of doctoral supervisors. In contexts where supervisory capacity and experience is lacking, a cohort model might also go a long way in addressing this constraint to successful doctoral writing.

Earlier we identified two potential sites of tension-border crossing for students transitioning into their chosen disciplinary community and knowledge domain and border maintenance for supervisors protecting the integrity of their disciplines. For students, this tension involves three areas-negotiating the identities they bring to the doctoral journey; understanding the values, organising principles, procedures, and established practices underpinning how knowledge is produced in their discipline; as well as contesting these dis- 
ciplinary norms and conventions. For supervisors, this tension involves providing access to these disciplinary norms and conventions for their students and encouraging contestation and the emergence of the doctoral voice while simultaneously maintaining the integrity of their disciplines.

Can these tensions be resolved? Disciplinary norms and conventions that have evolved over time are typically stable and involve much consensus about the existing canon within a particular field. And yet, surely, we can envision a role for doctoral work that is inscribed by emerging powerful writers in taking the field forward. This might mean supervisors will best support their students' writing by holding the tensions lightly while enabling their students' crossings of boundaries through alternative approaches to supervision.

\section{References}

Andresen, L. W. (2000). A useable, trans-disciplinary conception of scholarship. Higher Education Research and Development, 19(2), 137-153. https://doi. org/10.1080/072943600445619

Barnett, R. (2009). Knowing and becoming in the higher education curriculum. Studies in Higher Education, 34(4), 429-440. https://doi. org/10.1080/03075070902771978

Bazerman, C. (1994). Constructing experience. Southern Illinois University Press.

Bazerman, C., Bonini, A., \& Figueiredo, D. (Eds.). (2009). Genre in a changing world. The WAC Clearinghouse; Parlor Press. https://doi.org/10.37514/ PER-B.2009.2324

Benmore, A. (2016). Boundary management in doctoral supervision: How supervisors negotiate roles and role transitions throughout the supervisory journey. Studies in Higher Education, 41(7), 1251-1264. https://doi.org/10.1080/03075079.2 014.967203

Boughey, C. (2005). ‘'Epistemological’ $\backslash$ access to the university: An alternative perspective. South African Journal of Higher Education, 19(3), 638-650. https://doi. org/10.4314/sajhe.v19i3.25516

Boughey, C. (2013). What are we thinking of? A critical overview of approaches to developing academic literacy in South African higher education. Journal for Language Teaching, 47(2), 25-42. https://doi.org/10.4314/jlt.v47i2.2

Boughey, C., \& McKenna, S. (2016). Academic literacy and the decontextualised learner. Critical Studies in Teaching and Learning, 4(2), 1-9. http://cristal.epubs. ac.za/index.php/cristal/article/view/80

Burford, J. (2017). Conceptualising doctoral writing an affective-political practice. International Journal of Doctoral Studies, 12, 17-32. https://doi.org/10.28945/3689

Canagarajah, S. (2002). Multilingual writers and the academic community: Towards a critical relationship. Journal of English for Academic Purposes, 1(1), 29-44. https:// doi.org/10.1016/S1475-1585(02)00007-3 
Clarence, S., \& McKenna, S. (2017). Developing academic literacies through understanding the nature of disciplinary knowledge. London Review of Education. 15(1), 38-49. https://doi.org/10.18546/LRE.15.1.04

Department of Higher Education and Training. (2019). Annual report 2018/19. Republic of South Africa. https://www.gov.za/sites/default/files/gcis_document/202002/dhetannualreport201819web.pdf

Doyle, S., Manathunga, C., Prinsen, G., Tallon, R., \& Cornforth, S. (2018). African international doctoral students in New Zealand: Englishes, doctoral writing and intercultural supervision. Higher Education Research E Development, 37(1), 1-14. https://doi.org/10.1080/07294360.2017.1339182

Gee, J. P. (1990). Social linguistics and literacies: Ideology in discourses. Falmer.

Gee, J. P. (2008). What video games have to teach us about learning and literacy. Palgrave Macmillan.

Geisler, C. (1994). Academic literacy and the nature of expertise: Reading, writing, and knowing in academic philosophy. Lawrence Erlbaum Associates. https://doi. org/10.4324/9780203812174

Heath, S. B. (1983). Ways with words: Language, life and work in communities and classrooms. Cambridge University Press. https://doi.org/10.1017/ CBO9780511841057

Inouye, K., \& McAlpine, L. (2019). Developing academic identity: A review of the literature on doctoral writing and feedback. International Journal of Doctoral Studies, 14, 1-31. https://doi.org/10.28945/4168

Jacobs, C. (2005). On being an insider on the outside: New spaces for integrating academic literacies. Teaching in Higher Education, 10(4), 475-487. https://doi. org/10.1080/13562510500239091

Jacobs, C. (2007). Towards a critical understanding of the teaching of discipline-specific academic literacies: Making the tacit explicit. Journal of Education, 41,59-81. https://joe.ukzn.ac.za/Libraries/No_41_2007/Towards_a_critical_understanding_of_the_teaching_of_discipline-specific_academicliteracies_making_the_tacit_explicit.sflb.ashx

Jacobs, C. (2010). Collaboration as pedagogy: Consequences and implications for partnerships between communication and disciplinary specialists. Southern African Linguistics and Applied Language Studies, 28(3), 227-237. https://doi.org/10.29 89/16073614.2010.545025

Jacobs, C. (2013). Academic literacies and the question of knowledge. Journal for Language Teaching, 47(2), 127-138. https://doi.org/10.4314/jlt.v47i2.7

Jacobs, C. (2015) Opening up the curriculum: Moving from the normative to the transformative in teachers' understandings of disciplinary literacy practices. In T. Lillis, K. Harrington, M. R. Lea, \& S. Mitchell (Eds.), Working with academic literacies: Case studies towards transformative practice (pp. 131-141). The WAC Clearinghouse; Parlor Press. https://doi.org/10.37514/PER-B.2015.0674.2.09 Jacobs, C. (2019, November 27-29). Placing knowledge at the centre of how we understand 'good (enough) teaching' [Keynote address]. Higher Education Learning and Teaching Association of Southern Africa (HELTASA) 2019 National Confer- 
ence, Rhodes University, Grahamstown, South Africa. https://www.youtube. $\mathrm{com} /$ watch?v=BUXHGCXcOMc\&list=PLe454_1XjIKQA0x2GpAcTYEJnZs163QCU\&index $=5$

Jazvac-Martek, M. (2009) Oscillating role identities: The academic experiences of education doctoral students. Innovations in Education and Teaching International, 46(3), 253-264. https://doi.org/10.1080/14703290903068862

Kamler, B., \& Thomson, P. (2014). Helping doctoral students write: Pedagogies for supervision (2nd ed.). Routledge. https://doi.org/10.4324/9781315813639

Lamont, M., \& Molnár, V. (2002). The study of boundaries in the social sciences. Annual Review of Sociology 28(1), 167-195. https://doi.org/10.1146/annurev. soc.28.110601.141107

Leibowitz, B. (2012). Introduction: Reflections on higher education and the public good. In B. Leibowitz (Ed.), Higher Education for the public good: Views from the South (pp. xvii-xxvii). Trentham Books \& SunMedia.

Maistry, S. M. (2017). Betwixt and between: Liminality and dissonance in developing threshold competences for research supervision in South Africa. South African Journal of Higher Education 31(1), 119-134. https://doi.org/10.20853/31-1-841

Maton, K. (2014). Knowledge and knowers: Towards a realist sociology of education. Routledge. https://doi.org/10.4324/9780203885734

Maton, K., \& Moore, R. (Eds.). (2010). Social realism, knowledge and the sociology of education: Coalitions of the mind. Continuum.

McKenna, S. (2014). Higher Education Studies as a field of research. The Independent Journal of Teaching and Learning, 9(1), 6-16. https://hdl.handle.net/10520/ EJC161436

McKenna, S. (2017a). Crossing conceptual thresholds in doctoral communities. Innovations in Education and Teaching International, 54(5), 458-466. https://doi.or g/10.1080/14703297.2016.1155471

McKenna, S. (2017b, April 21). Unmasking the doctorate. University World News: Africa Edition. https://www.universityworldnews.com/post.php?sto$\mathrm{ry}=2017042113152878$

McKenna, S. (2019a, November 6). South Africa takes steps to assure the quality of its doctorates. The Conversation. http://theconversation.com/south-africa-takessteps-to-assure-the-quality-of-its-doctorates- 125774

McKenna, S. (2019b, December 5). The model of PhD study at South African universities needs to change. The Mail and Guardian. https://mg.co.za/article/2019-1205-00-the-model-of-phd-study-at-south-african-universities-needs-to-change/

Padmanabhan, M. C., \& Rossetto, L. C. (2017). Doctoral writing advisors navigating the supervision terrain. Innovations in Education and Teaching International, 54(6), 580-589. https://doi.org/10.1080/14703297.2017.1348961

Prokkola, E.-K. (2009). Unfixing borderland identity: Border performances and narratives in the construction of self. Journal of Borderlands Studies, 24(3), 21-38. https://doi.org/10.1080/08865655.2009.9695737

Samuel, M., \& Vithal, R. (2011). Emergent frameworks of research teaching and learning in a cohort-based doctoral programme. Perspectives in Education 29(3), 
76-87. http://hdl.handle.net/10413/11029

Scollon, R., \& Scollon, S. B. K. (1981). Narrative, literacy and face in interethnic communication. Blackwell.

Segal, J., Paré, A., Brent, D., \& Vipond, D. (1998). The researcher as missionary: Problems with rhetoric and reform in the disciplines. College Composition and Communication, 50(1), 71-90.

Starfield, S. (2004). Word power: Negotiating success in a first-year sociology essay. In L. J. Ravelli \& R. A. Ellis (Eds.), Analysing academic writing: Contextualised frameworks (pp 66-83). Continuum.

Street, B. V. (1984). Literacy in theory and practice. Cambridge University Press. Tardy, C. M, \& Matsuda, P. K. (2009). The construction of author voice by editorial board members. Written Communication, 26(1), 32-52. https://doi. org/10.1177/0741088308327269

Thesen, L. (2013). Risk as productive: Working with dilemmas in the writing of research. In L. Thesen, \& L. Cooper (Eds.), Risk in academic writing: Postgraduate students, their teachers and the making of knowledge (pp. 1-26). Multilingual Matters.

van Schalkwyk, S. C. (2007). Crossing discourse boundaries-Students' diverse realities when negotiating entry into knowledge communities. South African Journal of Higher Education, 21(7), 954-968. https://doi.org/10.4314/sajhe.v21i7.25754

van Schalkwyk, S. (2016). Academic literacy revisited: A space for emerging postgraduate voices? In L. Frick, V.Trafford, \& M. Fourie-Malherbe (Eds). Being Scholarly: Festschrift in honour of the work of Eli M. Bitzer (pp. 145-153). SunMedia.

van Schalkwyk, S., Bitzer, E., \& van der Walt, C. (2009). Acquiring academic literacy: A case of first-year extended degree programme students. Southern African Linguistics and Applied Language Studies, 27(2), 189-201. https://doi.org/10.2989/ SALALS.2009.27.2.6.869

van Schalkwyk, S., \& McMillan, W. J. (2016). 'I have a chameleon-like existence': A duoethnographic account of border crossing by two academic development practitioners. South African Journal of Higher Education, 30(6), 207-223. https:// doi.org/10.20853/30-6-735

Waghid, Y. (2015). Are doctoral studies in South African higher education being put at risk? South African Journal of Higher Education, 29(5), 1-7. http://hdl. handle.net/10019.1/104312

Wenger, E. (2000). Communities of practice and social learning systems. Organization, 7(2), 225-246. https://doi.org/10.1177/135050840072002

Williams, C., \& Lee, A., (1999). Forged in fire: Narratives of trauma in Ph.D. supervision pedagogy. Southern Review: Communication, Politics \& Culture, 32(1), 6-26.

Wilmot, K. (2020). Building knowledge with theory: Unpacking complexity in doctoral writing. Critical Studies in Teaching E Learning, 8(2), 18-38. https://doi. org/10.14426/cristal.v8i2.265

Wisker, G., \& Savin-Baden, M. (2009). Priceless conceptual thresholds: Beyond the 'stuck place' in writing. London Review of Education, 7(3), 235-247. https://doi. org/10.1080/14748460903290207 


\title{
Queer Path-Making: Expressing or Suppressing Creativity in Arts Doctoral Writing
}

\author{
Steven Thurlow \\ The University of Melbourne
}

\begin{abstract}
An insistent and rapacious call for innovation exists at the heart of academic knowledge production. However, the desire to produce a novel product does not appear to extend to notions of creativity in doctoral writing contexts. In this chapter, I explore how doctoral writers in the Faculty of Arts at an Australian university engage with the notion of creativity, both in relation to what it is or might be and where it is found. Building on my earlier work written with Janne Morton and Julie Choi (2019), I trace the diverse and changing perceptions of creativity held by three multilingual doctoral writers throughout their candidature. I utilise the work of Sara Ahmed (2006, 2018, 2019) to reveal how arts doctoral writers may diverge from the well-worn path of "standard" doctoral writing to forge their own unique trail of textual creativity despite the potential dangers posed by this deviation. While the "innovative idea" may be celebrated in the academy, any overtly creative expression could provoke an adverse reaction from disciplinary readers. This adverse reaction commonly led to a critical moment for doctoral writers, as their creative efforts were either sanctioned or forbidden by these powerful gatekeepers. If writers do risk leaving the "safe" path, I demonstrate how this could involve overcoming significant personal, cultural, and institutional obstacles. Ultimately, I show how some arts doctoral writers queer their writing by imagining and then acting upon a desire to produce creative written work. They also queer their doctorate by raising their writers' voices in a space typically enveloped in denial and silence.
\end{abstract}

Re-imagining the doctorate (Scene): Your thesis or dissertation should be 80,000 words long but no other boundaries exist-either about what you write or how you write it. Any style, any perspective, using any 
voice you like. No specific words, structures, or approaches are forbidden; nothing is out of bounds. To do this work, your writing practices should be creative as well. So, instead of paraphrasing endless journal articles into turgid academic prose in a darkened room, you might sit in a sunny park jotting down your research findings using techniques borrowed from your favourite creative non-fiction author. If you feel the need for company, a range of writing groups are available to support you. In their cosy embrace, you share the creative notions you have on your topic among critical but kind peers and teachers.

This chapter re-imagines doctoral writing. It imagines doctoral writers exploiting their natural and learned creativity, opening up fully to its fruitful embrace. However, this vision, like the fantasy scene above, is far removed from the reality of the contemporary doctorate.

At the core of this re-imagining is the enigma of creativity and our imprecise understanding of what it actually is. One widespread definition by Robert Sternberg and Todd Lubart (1998) asserted that creativity "is the ability to produce work that is both novel (i.e., original, unexpected) and appropriate (i.e., useful, adaptive concerning task constraints)" (p. 3). While helpful, this perspective firmly ties creativity to the appearance of a creative product and the way in which this product is received and subsequently used. It also conflates creativity with other semi-synonymous terms such as originality and novelty, which may be, in fact, quite different creatures. Ultimately, I have become wary of such attempts to pin down creativity and now accept its ability to disregard neat definitions as part of its essentially rebellious nature. Challenging conventions and thriving on uncertainty, creativity finds its home on the contested peripheries of epistemological knowledge.

Nowhere is creativity's peripheral status more pronounced than in doctoral contexts. Despite brave attempts to consider creativity's role in doctoral studies (Bargar \& Duncan, 1987; Lovitts, 2007), in doctoral education and pedagogy (Brodin, 20I8; Brodin \& Frick, 20II; Frick, 20I2), in academic identity development (Frick \& Brodin, 2020), and in doctoral writing itself (Badenhorst et al., 2015), it remains a frustratingly slippery term. From the literature, the concept of creativity and doctoral education are rarely combined, a situation Eva Brodin (2018) viewed as a "stifling silence" (p. 655) However, scholars such as Christine Pearson Casanave (2010) and Doreen Starke-Meyerring (20II) have highlighted how multilingual doctoral students writing in English as an additional language (EAL) might approach their work creatively, despite the risk and paradox it presents.

The current study explores how doctoral writers in the Faculty of Arts at an Australian university engaged with the notion of creativity regarding their 
writing and writing practices, both in relation to what it is or might be and where it is found. Building on my previous work with Janne Morton and Julie Choi (2019), this study traces three multilingual doctoral writers during their candidature. Changing perceptions of creativity were elicited through discussion and analysis of their writing. Using the work of Sara Ahmed (2006, 20I8, 2019), I investigate the decisions made by these writers to either remain on the well-trodden path of "standard" doctoral writing or else forge their own unique trail of creativity - often following a critical incident during their studies. If they did decide to leave the "safe" path- for even a relatively minor diversion-I show how this risk involved overcoming significant personal, disciplinary, and institutional obstacles. My hope is that this study will contribute to a re-imagining of the place of creativity in doctoral writing.

\section{Queering the Frame}

I utilize queer theory in this chapter as a strategy of critique to investigate the notion of creativity in doctoral writing and to illuminate the complex, shifting role creativity holds for my participants. Like creativity, the parameters around "queer" are similarly contested and evolving. Also, similar with creativity, it could be argued that binding definitions are perhaps unnecessary. Indeed, queer theorists see this fluidity as part of its epistemological strength. For instance, Annamarie Jagose (I996) wrote that queer's "definitional indeterminacy, its elasticity ... part of queer's semantic clout [and] political efficacy, depends on its resistance to definition" (p. I), while David Halperin (I995) asserted that "by definition [queer is] whatever is at odds with the normal, the legitimate, the dominant" (p. 62). Following Bryant Alexander (2017), I use queer to signify "a resistance to orthodoxy-expounding, elaborating and promoting alternative ways of being, knowing and narrating experience" (p. 278).

Applying queer to research, James Burford and Louisa Allen (2019) recognized its usefulness in three senses: queer as a term to unsettle categories associated with heterosexual identities; queer as referring to non-heterosexual, sexual, and gender practices; and queer as a broadly political term and tool for analysis. It is this last meaning that I address here. Deborah Britzman (I995) asserted that, used in this way, "the queer and the theory in queer theory signify actions, not actors" (p. 153). This emphasis on queer as a verb-that is, queering as an action-rather than as affirming a certain identity or practices informs this piece. In higher education research, Burford and Allen (2019) recognised a common feature across the three senses of queer is its ability "to offer more nuanced accounts of what is constructed as 'normal' and 'natural' in university contexts, and which social groups are privileged by such constructions” (p. I3I). 
Boundary work is part and parcel of queer theory, exposing how normalized behavior in institutions can be identified, negotiated, and, if need be, challenged. In Ahmed's (2006) Queer Phenomenology, she posited that social boundaries are negotiated through following directional lines. These lines serve to orient us or join us to others in a line, thus preventing disorientation and cementing social relationships. Lines can also lead us to intentionally or unintentionally repeat what others have done:

The lines that direct us, as lines of thought as well as lines of motion, are in this way performative; they depend on the repetition of norms and conventions, of routes and paths taken, but they are also created as an effect of this repetition. (Ahmed, 2006, p. I6)

The time, energy and resources needed to follow these "lifelines" ensure they become a form of social investment and could ultimately lead to subjects reproducing the lines that they follow, although this is not always a conscious choice. Paths and path-making are another recurring motif for Ahmed. Put simply, "a path is made by the repetition of the event of the ground being 'trodden upon' ... a path 'clears' the way" (Ahmed, 2006, p. I6). Paths can be straight and well-used or deviate and be ill-used. Unsurprisingly, Ahmed (2019) has equated heterosexuality with the straight path, "one that is kept clear not only by the frequency of use ... but also by an elaborate support system" (p. 204). A queer use would be to deviate from this straight path. While not impossible, she has acknowledged that taking this queer route requires a strong effort: "Deviation is hard; deviation is made hard" (Ahmed, 2019, p. 42).

Ahmed's concepts mesh well with doctoral education. For many Ph.D. candidates, lines, paths, and boundaries are unclear during their doctoral journey, and the achievement of key milestones such as confirmation (signalling the end of probationary candidature at Australian universities) may only occur through trial and error. In this arduous journey, the siren call to emulate what others have done is strong, doubly so when coupled with the magnetic force of disciplinary traditions. Yet, resistance is possible. Genre studies scholar Christine Tardy (2016) outlined several common reasons why academic writers might wish to innovate, all highly relevant to doctoral writers. These include a desire to bring forth alternate knowledge and ways of knowing, to incorporate self-expression and assist reader engagement, and to critique and change dominant discourses (see also Molinari, Chapter 2, this collection). Running in parallel to these worthy intentions, however, is the pressure to follow tried and true conventions of what academic writing should look and sound like. The siren call to follow a persistent and well-trodden path beck- 
ons, and any deviation from this route, possibly through introducing creative elements, is risky.

In making these decisions about how to proceed, the candidate faces a series of critical incidents-times when knowledge of what is required from them is sharply clarified-often after a troubling event. For David Nunan and Julie Choi (20I0), a critical incident is "an event that stimulates the individual to restructure their understanding of the nexus between language, culture and identity" (p. 6), while Alastair Pennycook (2004) preferred the term "critical moment," describing it as "a point of significance, an instant when things change" (p. 330). Bo Edvardsson's (1992) definition links critical incidents to deviance from expectations: "For an incident to be described as critical, the requirement is that it can be described in detail and that it deviates significantly, either positively or negatively, from what is normal or expected" (p. I7). Echoing Pennycook (2004), Ahmed (2006) believes these key moments when we change course force a decision regarding a future direction. Facing this "fork in the road," (2006, p. I9) a path is chosen. However, doubts soon creep in, and this uncertainty could slow progress. For Ahmed (2006), these moments are when "doubt gets in the way of hope" and we stop following a directional line "as abruptly as turning a switch" (p. I8-I9). For doctoral students, however, going off-course brings decided benefits with such sideways moves or deviations possibly resulting in fruitful, chance encounters that "open up new worlds" and thus, create new knowledge" (Ahmed, 2006, p. I9). While acknowledging that "such moments can be a gift," they could also be "a site of trauma, anxiety, or stress about the loss of an imagined future" (Ahmed, 2006, p. I9). In the doctorate, this "imagined future" necessarily involves the submission of a written thesis.

Through my investigations, I came to see creativity as a force for positive tension in doctoral writing contexts, although its exact shape remained uncertain. Initially, I believed that tracking the path of a possible creative "deviation" would be visible from the textual product; that is, I believed creativity could be discerned at the word, sentence, or paragraph level of the text itself. However, I quickly realized that identifying instances of possible deviation/s through the assessment of writing was not giving me a complete picture. Doctoral writing changes rapidly, with modifications mostly occurring away from public gaze-behind closed doors in supervisory meetings, in late night email exchanges, and in the "track changes" function of Microsoft Word or other feedback mechanisms. Often, after an unauthorized creative deviation has been spotted — usually by a supervisor — the writing draft is "tidied up," with any evidence of this creativity removed. If left in, the creative element might be so minor or so dependent on knowledge of disciplinary conventions 
that it becomes almost invisible for an "outside" reader to detect it. Therefore, in exploring creativity in doctoral writing contexts, I was forced to widen my gaze, focusing not only on written products of the doctorate but also on the writers' perspectives on creativity and the processes and practices they undertook in their studies. I also needed to trace how these elements shifted during the three or four years' intensive, lived experience of the doctorate.

\section{The Current Study: Creativity and Creative Practices in Doctoral Writing Contexts}

This study set out to collect the perceptions of doctoral writers regarding creativity and creative practices in their written work. It was based on a series of discourse-based interviews and a collection of written artefacts from three multilingual doctoral writers. These candidates were international students based in the Faculty of Arts in a large, research-intensive Australian university between 2016 and 20I9. I chose to research international, multilingual writers as, to some extent, they remain outside the institutional system-routinely being "parachuted" into their doctoral studies from diverse educational backgrounds. In addition, these students frequently struggle with the demands of the doctorate and may risk non-completion (Casanave \& Li, 2008; Paltridge \& Starfield, 2007).

I enlisted these three doctoral writers; Renato, Sofia, and Bianca (all pseudonyms) in the context of a doctoral writer's group for arts students that I facilitated as part of my job as an academic writing teacher at the university in 20I6. All three were undertaking the standard "big book" thesis/dissertation with no requirement for an exegesis or other "official" creative component (see Ravelli et al., Chapter II, this collection, for accounts of theses in the visual and performing arts). I sought and gained ethics permission to follow up with participants from the writer's group, involving semi-regular individual interviews over a four-year period and one focus group discussion held in 20I7. While most of these encounters followed a pre-determined list of questions, I kept the final interview relatively unstructured. These meetings provided valuable opportunities for us to build rapport and for me to observe the participants' longitudinal writing development. The collected data from our meetings-including interview transcriptions and self-selected extracts of the participants' writing-were analyzed for key themes (cf. Leki, 2007). Theme selection was oriented toward major writing issues such as identity, voice, agency, and risk.

While the entire interview series explored intersections between creativity and doctoral writing contexts, the final interview in 2019 focused on critical 
moments experienced by the three students over their whole doctoral journey. My desire to explore critical incidents was framed in general terms, such as "describe the best and worst things you've experienced during your studies." Using a simple, hand-written timeline, I "fished" for key events that triggered a change in the practice or products of their writing (Choi \& Slaughter, 2020) and used simple open-ended questions focusing on events and feelings (cf. Spencer-Oatey, 20I3).

\section{The Narratives}

A queer theory analysis of key critical incidents during the participants' studies serves to illuminate the often-secretive role that creativity played over time for this trio of multilingual doctoral writers. Tracking how these writers experienced and utilized creativity in doctoral writing contexts throughout their four-year candidature resulted in an abundance of data. However, this chapter focuses on our final two interviews (2018 and 2019). This short section cannot fully reflect the rich discussions I had with each writer regarding creativity. Instead, excerpts from individual interviews highlight the complex role creativity played in selected critical moments, illustrating how creativity in doctoral writing was both imagined and constructed or otherwise rendered unavailable to these writers.

\section{Renato: The Strategic Outlier}

An Italian criminologist and philosopher in his mid-2os, Renato left his city in southern Italy for higher education the United Kingdom. He arrived in Australia to continue graduate study two years before commencing his doctorate. He identified as a bi-lingual speaker (Italian and English), although he claimed to solely write in English. For Renato, using creativity in his research linked his work to the growing importance of subjectivity in his discipline, historical criminology. He used creativity to provide a logical framework for his ideas and help convey a precise and forceful message to readers. He also appreciated its role in knowledge creation, proclaiming, "The beauty of research, the joy of theory-that's where the real beauty, the true potential of creativity lies." Throughout his doctorate, Renato carefully considered how much creativity to include in his writing. He acknowledged the crucial role his discipline and readers had on shaping his work and demonstrated a keen awareness of what was rhetorically acceptable in written discourse in his field, observing, "Discourse is regulated by certain principles and the moment you don't follow those principles, you find yourself outside that discourse. With- 
out using the right criminological language, my colleagues will not realise the value of it." Deciphering disciplinary boundaries was clearly not problematic for Renato. However, he occasionally tested constraints, stating, "I try to find my own boundaries ... I can be really creative, but I also know when I need to keep my creativity in check." Ahmed (2006) might frame this awareness of the parameters of acceptability as a response to the strength of disciplinary lines:

Disciplines also have lines in that they have a specific 'take' on the world; a way of ordering time and space through the very decisions about what counts as within the discipline. Such lines mark out the edges of disciplinary homes, which also mark those who are out of line. (p. 22)

Playing with creativity in the writing process was important to Renato, particularly at the drafting stage. He explained, "So many times, the creative element is really an excuse to entertain myself apart from anything else." This comment suggests that using creativity while drafting stimulated his interest and facilitated idea generation. This sentiment echoes the findings of Brittany Amell and Cecile Badenhorst (2018), who believe that "invoking a sense of playfulness towards one's [writing] practice may provide ... tools to navigate through difficulty to meaningful understanding"(p. 28). In a written reflection in 2019, however, Renato recognized that the writer's consciousness needs to move from the more free-spirited processes of creation to more mundane, product-focused concerns, noting, "Creativity takes a backseat as candidature approaches submission deadline. Considerations made from the perspective of the artist-beauty, rhetoric, innovation - are suspended. Enters the artisan-attention to detail, accuracy, validity and usability."

This withdrawal from creativity and creative practices before submission presented a difficult adjustment for Renato, as he was instinctively drawn to the big picture idea rather than detail. Nevertheless, he displayed a keen awareness of his tenuous role as an apprentice academic, stating,

You are kind of playing with the rules; sometimes it [creativity] is unacceptable; that's why you have to conceal. But often the ones that do have [academic] success are the ones that breach the conventions in a particular field; they come up with new rules for the game ... If that's not an act of creativity, I don't know what is.

This ability to introduce a degree of creativity into his work may have resulted from his understanding of what Pierre Bourdieu (1998) termed the "sportsman's feel" for the game, alluding to the game played among cultural agents that 
provides a skilled player such as Renato with the knowledge to make strategic decisions regarding which discourses, genres, or practices are appropriate under certain circumstances. It also demonstrates not only his understanding of the potential rewards of being creative but also the need for concealment until a time when unbridled creativity can flourish. This ability to conceal but also strategically reveal creativity highlights Renato's flexibility as an academic writer and his manipulation of writing processes to further his writing goals.

Renato also felt creativity was present in his written expression, particularly in his use of dense sentence structure. Interestingly, he saw the construction of lengthy, complex sentences as critical to the emergence of textual creativity, commenting,

The moment when I am writing longer sentences, I feel like something is going on. Trying to create a stronger message without moving away from the initial idea; like the reinforcement. This is the moment that I feel I'm being really creative; that moment after the comma.

He wanted to keep what he termed this "Italianness" in his work but throughout our interviews hinted at ongoing tussles with a member of his supervisory team who preferred a much leaner written style (see Thurlow, 202I, for more detail on this tension).

From these brief observations regarding creativity in his doctoral practices and textual products, we can see glimpses of Renato as a playful maverick in his use of periodic creativity in his work. Nevertheless, his care to respect disciplinary expectations when he did utilize creativity marks him as a creative risk-taker. From our discussions, it appears that no major critical incidents marked him as "out of line" in his field. Rather, his confidence and skill as a writer meant that any queer deviation he undertook in his writing practices and final thesis/dissertation were most probably recognized and ultimately accepted by his academic readers.

\section{Sofia: The Vagaries of Voice}

A scholar of Spanish literature, Sofia arrived in Australia to begin her doctorate in 2016 after completing a master's degree at a U.S. university. In her late 20s, she was fluent in both Spanish (her first language), Catalan, and English. For Sofia, creativity in her research meant being open to new ideas and linking apparently unrelated topics together. Creativity in her doctoral writing entailed combining novel ideas and expressing them in a personal, understandable way. 
A recurring theme in our interviews concerned establishing and maintaining writer's voice. Sofia believed that finding an appropriate personal voice in writing required confidence and only then might creativity start to emerge. For example, her 2018 comment, "It's something I'm working on," is emblematic of her own varying levels of self-assurance during our meetings. Picturing an interested reader helped Sofia to access a more confident voice and produce "less boring" material.

Despite this, using reader engagement devices such as the subjective "I" was clearly challenging for Sofia. In 2019, when discussing her primary supervisor's perspective on this topic, her voice quietened and the tone became almost confessional:

He doesn't like the “I." He's been very consistent. Any time I put them in he would change it or delete. If he had seen this [refers to an "I" in her text], he would have changed it to something else ... It's not resolved.

As ever, the use of "I" in academic writing is contentious. Even in the contemporary humanities, where Sofia researched, proclaiming a strong personal identity in academic writing is rare. Alphonso Lingis (2007) saw its use as an "awakening," indicating a fundamental separation with others' company and discourses. Sofia's sensitivity to the topic reveals a vexatious relationship with what Roz Ivanič (1998) might have termed her "discoursal self," the voice that effectively regulates how the self is constructed through writing, and its unresolved status provoked a critical moment. Ahmed (2006) has pondered why such consternation exists over personal digression, sensibly asking, "Why is it that the personal so often enters writing as if we are being led astray from a proper course?" (p. 22).

Despite these reservations, maintaining a degree of subjectivity in her writing was confirmed for Sofia during the process of writing a journal article. In this endeavour, she was encouraged by the journal editors to include more engagement techniques, including personal pronouns. However, an anxious critical moment regarding writer's voice ensued once more:

I wasn't putting myself enough in the text; they [the editors] couldn't see me. They could see a lot of quotes but they couldn't see me; I wasn't showing what I thought ... . But it was not my first choice and I would not say that I learned like this; the use of the $\mathrm{I}$ is not very me.

I saw Sofia as still struggling to represent herself in her work in a way that could give her complete satisfaction. I asked her which textual voice would 
appear if she had a free choice, and she responded, "I feel my style would be something in the middle ... Free to use it, the 'I,' but not being forced to use it because someone says I cannot hear the voice of the author here."

Even after completing writing, Sofia found it difficult to release her work, making repeated references to her perfectionism throughout our interviews. During drafting, she told herself, "Stop trying to do everything perfect from the first time ... [stop] thinking in some kind of perfect structure; from paragraph to paragraph; everything linked." As a result of this self-talk, she stated she was "unlearning" key core features of academic writing, such as topic sentences and paragraph structure, and this process represents yet another critical moment in her doctoral studies. Even coming to the decision that the standard writing process might be unsuitable for her context took considerable time and effort. She would clearly love to feel more pride in her work but admitted that "small things" like a missing comma could set off a great deal of anxiety. For Ahmed (2006), this could indicate a feeling of identity-based disorientation: "We can also lose our direction in the sense that we lose our aim or purpose: disorientation is ... when we lose our sense of who it is that we $\operatorname{are}$ (p. 20). Sofia needed to beware that such moments of disorientation would not further erode her sense of confidence in her work and overwhelm her candidature. During times of crisis, Ahmed (2006) warned, "when we tread on paths that are less trodden, which we are not sure are paths at all ... we might need even more support" (p. I7o).

Sofia's words remind us that overt subjectivity in writing brings attentionand attention brings risk to the writer. Specifically, complexities around use of personal pronouns can prompt a critical moment for doctoral writers as they negotiate the boundaries of subjectivity in their work. Sofia, however, clearly intended to avoid this risk, but a significant danger remained as to whether she would be able to assume the role of a visible and confident authority in her written doctoral work. Despite tussles over subjectivity, I believe she was on the path to queering her writing. This is shown through a desire to better communicate her ideas through a process of questioning-and occasionally rejecting-some staples of academic writing, such as the use of topic sentences and other aspects of "standard" academic paragraph structure, in her work.

\section{Bianca: Making it to the End}

From a large, northern Italian city, Bianca's first language was Italian. Arriving in Australia three years before commencing her doctorate, she maintained work as an Italian language teacher throughout her studies. In her early thirties, she was fluent in several European languages and researched 
bilingualism. For Bianca, creativity in her research meant being able to combine different writing styles and diverse approaches to research without being bound to the practices of her discipline of applied linguistics. The ability to use a range of voices in her work encapsulated the concept of creativity in doctoral writing for her.

At first, Bianca was the most enthusiastic of my three participants in a desire to create engaging writing for her readers. In 20I6, she stated, "You are not saying something that others have said [so] you have to present it differently." However, in 2019 she had moved away from thoughts of "seducing the reader," with an uncomfortable mixture of impatience and ennui now permeating the writing up process for her. She explained, "My goal is to pass the Ph.D. in a way ... with the less pain possible."

Bianca's writer's voice also diminished over time. In 2018, the "creative" extract of current writing she presented was, for me, virtually writer-less, apart from the presence of the "organising I" (Giltrow, 2002) and vastly different from a highly subjective and animated piece she shared two years earlier (see Thurlow, 202I, for detail on this earlier work). When I observed that her absence from her 2018 piece seemed a shame, this triggered an immediate, charged response:

I'm not concerned about whether it's a shame ... If I want to be creative about this topic, it can't be in my $\mathrm{Ph} . \mathrm{D}$., so like my Ph.D. is what I have to write and I'm told to write it in a certain way and I'm going to do it. If I want to be creative about this topic, it's going to be outside this 80,000 words.

Throughout our final two interviews, Bianca underlined the lack of creativity in her work and speculated on the causes of this. Her supervisors were obvious targets. She noted, "I feel like my hands are a bit tied ... I mean they [her supervisors] are not pushing me to be creative; maybe the opposite. It's more to do with non-creativity." However, she later attributed the "killing" of her personal creativity as a system-wide issue, declaring, "It's not their fault. They just reflect the system; they are just an ambassador for it." In her mind, the real culprit was the thesis assessment process itself. Specifically, she believed that the system of passing theses to an anonymous "expert" readers for final assessment inhibits creativity:

I still think they [her supervisors] just do it to play it safe . . . So they say "OK, if you write in a neutral way, it's going to be acceptable for the ones that are traditional and also the ones that are open-minded." But it's not vice-versa ... . if you 
are too lively in the way you write and you get a traditional examiner, you are going to be disadvantaged.

During this critical moment, recognition dawned for Bianca that the system would not change to accommodate her. This realisation that her writing must change led Bianca to introduce a degree of self-censorship into her work. Consistent with Michel Foucault's (1977) identification of self-discipline as controlling activity in institutions such as schools, hospitals, and prisons, Bianca's participation in doctoral "school" was subject to these controlling influences. From her observations, it appears that the veiled instrument of the thesis examination was the primary form of disciplinary power acting on her. As Foucault warned, "The exam's normalising gaze makes it possible to qualify, to classify and to punish" (p. 84). Indeed, for Bianca to pass the final writing hurdle, the responsibility for ensuring her work met disciplinary expectations ultimately rested with her. Therefore, a willingness to self-censor through self-surveillance may lie at the core of this power. This realisation clearly unsettled Bianca and impacted the degree of creativity she felt she could include in her work.

As a multilingual writer, Bianca was well aware how languages can express similar ideas differently. From this personal experience, she had gained a somewhat cynical perspective on how written English expression may constrain the writers' ideas, stating,

I have this prejudice that English speakers don't like things which are convoluted; ideas that convoluted anyway . . . Something that is convoluted in Italian is ... acceptable in Italian ... while in English it would be disregarded and discarded.

Related to this idea, she believed "proper" use of syntax in written English may stymy creative written approaches, commenting,

If you teach someone to work at the sentence or paragraph level, you are still embedding their creativity into some rules ... If they are going to follow these rules systematically, [a creative approach] sounds like a contradiction to me.

Therefore, the rigid rules of academic writing-especially at the clause and sentence level-would act to prevent the emergence of creativity in its freest and most unfettered form. This idea recalls Renato-also from an Italian language background-who felt at his most creative "the moment after the comma" in lengthy sentences but who acknowledged that long sentences may 
have been viewed as poor academic style by his readers. Hence, for both $\mathrm{Bi}$ anca and Renato, it appears that the precision so highly valued in academic English writing may have been a significant force against creativity in their own doctoral work.

As her thesis journey neared completion, creativity was an object in retreat for Bianca. She realized that including a form of creativity in her work would necessitate deviation from the sanctioned path of doctoral work and that this queer detour might risk delays or non-completion. During this process, she echoed Renato's recognition of disciplinary and other boundaries but, unlike him, seemed unable to strategically deviate from the well-trodden path by including elements of creativity in her thesis. Her eventual acquiescence to respect the occluded constraints surrounding creativity and re-produce a conventional form of doctoral writing occurred after several critical moments and a great deal of, mostly internalized, resistance.

\section{Re-imagining the Doctorate: Less Trodden Paths Toward Creativity}

Renato experienced a critical moment as he lodged the final version of his thesis for examination:

One interesting thing about the thesis submission process is that one of the [assessment criteria asks] whether the thesis contains a creative element or not ... like a piece of poetry. Obviously, my thesis just doesn't ... They [the examiners] basically get you to admit that what you've been doing is not creative.

Renato's astute reflection reminds us of the frequent yet often hidden intersections between doctoral writing and creativity. Although unquestionably connected to originality, a commonly included criterion for assessment of doctoral theses worldwide, creativity remains the poor cousin of the "Big O" and, therefore, largely absent from discussions of doctoral writing.

The doctoral thesis is not a document usually associated with rebellion and deviation. Yet a desire for difference does beat strongly in the hearts of these apprentice knowledge creators-able, creative people who want to share their novel ideas with the widest possible audience. This desire provides fertile ground for their work to germinate into something both useful and creative in writing. However, before this propagation can occur, "creative" doctoral writing needs to be authorized by the discipline and institution from which it springs. The writers themselves must also recognise the usefulness of creative 
approaches and have the courage to stray from the known path of doctoral writing to creatively queer their work.

This study's findings show doctoral writers clearly do grapple with creativity at critical moments of their candidature. Tracing these moments as experienced by Renato, Sofia, and Bianca throughout their candidature, we see their attraction to creativity for the inspirational and enlivening edge it can bring to their writing and for its ability to bring forth an engaging yet authoritative writer's voice. But what influence does creativity ultimately have on the written products of these three multilingual writers? Utilising queer theory and Ahmed's work on orientation/disorientation (2006) and path-making (2018, 2019), we see Renato, Sofia, and Bianca traversing a disorienting and somewhat intimidating landscape, joining growing numbers of international students on a similar journey. My findings suggest that Sofia and Bianca, although initially attracted to the notion of creativity and creative practices, were unlikely to leave the known path of how a thesis in their disciplines should look and sound. They seemed unwilling to risk a negative reaction from readers and, particularly at the end of their doctoral journey, lacking the confidence, time, and energy to take risks with creativity. As a result, they likely disciplined themselves to remain on their "safe" paths. In contrast, Renato had subtly re-made his path. I could see him queering his doctoral writing by challenging expectations about what might be creatively possible in it and playfully including what he termed "crumbs" of creativity into his work.

But why should we be satisfied with crumbs when a more substantial feast awaits? Before we dine, however, we must acknowledge the greater tension at work here between the forces of creativity and conventionality, which are knotted so tightly together in any thesis. Clearly, unravelling (or even loosening) these knots is difficult to do. However, through tracking the experiences of three doctoral students, I have found that resistance to the accepted path of doctoral writing into more creative terrain, although difficult, is possible. Indeed, for those with the stamina to persevere, creative deviation could bring multiple and lasting benefits. Ahmed (2006) has considered that such deviation can "help generate alternative lines which cross the ground in unexpected ways" (p. 20). Following these oblique lines could lead to new angles, novel perspectives, or innovative solutions to old problems. Ahmed (2018) believed that such radical changes in direction or perspective could ultimately jolt institutional systems such as traditional universities into transformative change, asserting, "a system [or] machine needs blockages to make it operate differently" (2018).

Despite the potential and obvious rewards of such deviant re-imaginings, this study finds that creativity in arts doctoral writing contexts is more about 
the potential of where it could be rather than where it currently is. Notwithstanding its current peripheral state, even a brief discussion about creativity could usefully raise awareness of this notion among those located at the heart of the doctorate: supervisors, their students, and other university educators who care about and support doctoral writing. Consciousness of creativity's presence and potential and of the forms it might take in doctoral writing contexts could provide powerful learning opportunities, especially if followed by hands-on, writing-focused workshops. In a re-imagined doctorate, this approach could ultimately persuade doctoral writers to more wholeheartedly accept creativity's transformative effects on their work.

\section{Acknowledgments}

Steven would like to thank the study participants and reviewers of this work for their time and thoughtful comments.

\section{References}

Ahmed, S. (2006). Queer phenomenology: Orientations, objects, others. Duke University Press.

Ahmed, S. (2018). Uses of Queer use. [Notes made from a lecture at The University of Melbourne on 23 October]. The University of Melbourne.

Ahmed, S. (2019). What's the use? On the uses of use. Duke University Press. https:// doi.org/10.1215/9781478007210

Alexander, B. (2017). Queer/Quare theory: Worldmaking and methodologies. In N. K. Denzin \& Y. S. Lincoln (Eds.), The SAGE handbook of qualitative research. (5th ed., pp. 275-307). Sage Publications.

Amell, B., \& Badenhorst, C. (2018). Introduction: Play, visual strategies and innovative approaches to graduate student writing development. Discourse and Writing/ Rédactologie, 28, 26-32. https://doi.org/10.31468/cjsdwr.724

Badenhorst, C., Moloney, C., Dyer, J., Rosales, J., \& Morgan, M. (2015). Thinking creatively about research writing. In T. Lillis, K. Harrington, M. R. Lea \& S. Mitchell (Eds.), Working with academic literacies: Case studies towards transformative practice (pp. 97-106). The WAC Clearinghouse; Parlor Press. https://doi. org/10.37514/PER-B.2015.0674.2.07

Bargar, R. R., \& Duncan J. K. (1987). Creativity in doctoral research: A reasonable expectation? The Educational Forum, 51(1), 33-43. https://doi. org/10.1080/00131728609335683

Bourdieu, P. (1998). Practical reason: On the theory of action. Polity.

Britzman, D. P. (1995). Is there a queer pedagogy? Or, stop reading straight. Educational Theory, 45(2), 151-165. https://doi.org/10.1111/j.17415446.1995.00151.x 
Brodin, E. M. (2018). The stifling silence around scholarly creativity in doctoral education: Experiences of students and supervisors in four disciplines. Higher Education, 75, 655-673. https://doi.org/10.1007/s10734-017-0168-3

Brodin E. M., \& Frick B. L. (2011). Conceptualizing and encouraging critical creativity in doctoral education. International Journal for Researcher Development, 2(2), 133-151. https://doi.org/10.1108/17597511111212727

Burford, J., \& Allen, L. (2019). Starting with queer: An enigmatic concept in higher education research and practice. In E. F. Henderson \& Z. Nicolazzo (Eds.), Starting with gender in international higher education research: Conceptual debates and methodological considerations (pp. 126-143). Routledge.

Casanave, C. P. (2010). Taking risks?: A case study of three doctoral students writing qualitative dissertations at an American university in Japan. Journal of Second Language Writing, 19(1), 1-16. https://doi.org/10.1016/j.jslw.2009.12.002

Casanave, C. P., \& Li, X. (Eds.). (2008). Learning the literacy practices of graduate school: Insiders' reflections on academic enculturation. University of Michigan Press. https://doi.org/10.3998/mpub.231189

Choi, J., \& Slaughter, Y. (2021). Challenging discourses of deficit: Understanding the vibrancy and complexity of multilingualism through language trajectory grids. Language Teaching Research, 25(1), pp. 81-104. https://doi. org/10.1177/1362168820938825

Edvardsson, B. (1992). Service breakdowns: A study of critical incidents in an airline. International Journal of Service Industry Management, 3(4), pp. 17-29. https:// doi.org/10.1108/09564239210019450

Foucault, M. (1977). Discipline and punish: The birth of the prison. Penguin.

Frick, B. L. (2012). Pedagogies for creativity in science doctorates. In A. Lee and S. Danby (Eds.). Reshaping doctoral education: International approaches and pedagogies (pp. 113-127). Routledge.

Frick, B. L., \& Brodin, E. M. (2020). A return to Wonderland: Exploring the links between academic identity development and creativity during doctoral education. Innovations in Education and Teaching International. 57(2), pp. 209-219. https://doi.org/10.1080/14703297.2019.1617183

Giltrow, J. (2002). Academic writing: Writing and reading across the disciplines (3rd ed.). Broadview Press.

Halperin, D. M. (1995). Saint Foucault: Towards a gay hagiography. Oxford University Press.

Ivanič, R. (1998). Writing and identity: The discoursal construction of identity in academic writing. John Benjamins. https://doi.org/10.1075/swll.5

Jagose, A. (1996). Queer theory. Melbourne University Press.

Leki, I. (2007). Undergraduates in a second language: Challenges and complexities of academic literacy development. Lawrence Erlbaum. https://doi. org/10.4324/9781315084442

Lingis, A. (2007). The first person singular. Northwestern University Press.

Lovitts, B. E. (2007). Making the implicit explicit: Creating performance expectations for the dissertation. Stylus. 
Nunan, D., \& Choi, J. (2010). Language, culture and identity: Framing the issues. In D. Nunan and J. Choi (Eds.), Language and culture: Reflective narratives and the emergence of identity (pp. 1-14). Routledge.

Paltridge, B., \& Starfield, S. (2007). Thesis and dissertation writing in a second language: A handbook for supervisors. Routledge. https://doi. org/10.4324/9780203960813

Pennycook, A. (2004). Critical moments in a TESOL praxicum. In B. Norton \& K. Toohey (Eds.), Critical pedagogies and language learning (pp. 327-345). Cambridge University Press. https://doi.org/10.1017/CBO9781139524834.017

Spencer-Oatey, H. (2013) Critical incidents. A compilation of quotations for the intercultural field. GlobalPAD Core Concepts. https://warwick.ac.uk/fac/soc/al/ globalpad-rip/openhouse/interculturalskills/cc_critical_incidents_131127.pdf

Starke-Meyerring, D. (2011). The paradox of writing in doctoral education: Student experiences. In L. McAlpine \& C. Amundsen (Eds.), Doctoral education: Research-based strategies for doctoral students, supervisors and administrators (pp. 75-95). Springer. https://doi.org/10.1007/978-94-007-0507-4_5

Sternberg, R. J., \& Lubart, T. I. (1998). The concept of creativity: Prospects and paradigms. In R. J. Sternberg (Ed.). Handbook of Creativity (pp. 3-15). Cambridge University Press. https://doi.org/10.1017/CBO9780511807916.003

Tardy, C. M. (2016). Beyond convention: Genre innovation in academic writing. University of Michigan Press. https://doi.org/10.3998/mpub.5173647

Thurlow, S. (2021). Creativity is for poets and pop singers isn't it? Academic perspectives on creativity in doctoral writing. Arts and Humanities in Higher Education, 20(2), 187-206. https://doi.org/10.1177/14740222220924286

Thurlow, S., Morton, J., \& Choi. J. (2019). You can't be Shakespearean talking about the institutionalisation of sex offenders: Creativity and creative practices of multilingual doctoral writers. Journal of Second Language Writing. 43, 46-56. https:// doi.org/10.1016/j.jslw.2017.11.002 


\title{
Meta-Generic Imaginings: Using Meta-Genre to Explore Imaginings of Doctoral Writing in Interdisciplinary Life Sciences
}

\author{
Sara Doody \\ University of British Columbia
}

Abstract: This chapter explores how doctoral writing is currently imagined in interdisciplinary life sciences doctoral programs (e.g., biophysics, computational biology) and aims to present avenues for how writing might be re-imagined in these contexts. Conceptualizing writing from a rhetorical genre theory perspective, which views writing as social and situated action, I explore meta-genres that dictate how writing is imagined and enacted in interdisciplinary doctoral programs. Using meta-genre analysis to explore how writing is imagined, talked about, conventionalized, and experienced, this chapter traces how deeply engrained and taken-for-granted assumptions about interdisciplinary writing may have significant consequences for doctoral writers. Imaginations of interdisciplinary writing as "translating," "simplifying," and "clarifying" that pervade talk about writing exist in contradiction with how writing is experienced by students. This arhetorical talk about writing serves to occlude the complex, situated, and deeply social negotiations interdisciplinary writers must engage in to work across disciplinary boundaries. In pointing out hidden contradictions between dominant imaginings of writing and writers' experiences, this chapter suggests that meta-genre offers potential to facilitate a rethinking of interdisciplinary writing. As a resource that encourages writers to critically reflect on how they are situated and how this situatedness impacts their writing practices, meta-genre has the potential to be an empowering resource for doctoral writers to peel away writing's arhetorical façade and engage in meaningful rhetorical activity. 
Research on doctoral writing has largely aimed to provide pedagogical interventions and aids for writers who are often (unfairly) burdened with the expectation that they should have learned how to write properly sometime before the doctorate (Starke-Meyerring, 20II). With writing often blamed for doctoral attrition, scholars of doctoral pedagogy have argued that doctoral writing is inherently social and a way of initiating doctoral writers into the very communities they are attempting to enter (Aitchison \& Lee, 2006; Kamler \& Thomson, 20I4; Lee \& Boud, 2009; Paré et al., 20II). Understanding writing as a way of entering into particular scholarly discourses and communities has led to the development of interventions, policies, and strategies aiming to provide doctoral students with support, often by attempting to change assumptions about doctoral writing from writing up to writing into (e.g., Aitchison \& Guerin, 20I4; Kamler \& Thomson, 20I4; Lee \& Boud, 2009; McAlpine \& Amundsen, 20II). This notion of writing into, while productive, has focused largely on what might be considered siloed disciplines: groups with fairly stable and established-albeit often implicit-expectations about writing (Starke-Meyerring et al., 20I4; Thurlow, Chapter 5, this collection). In interdisciplinary programs, which are becoming increasingly common worldwide (Nerad \& Heggelund, 2008), this way of thinking about students writing into only one scholarly research community becomes more complex and offers a site for reflection about the way doctoral scholarship conceptualizes and imagines doctoral writing.

Interdisciplinary programs are locales where previously siloed disciplinary ways of knowing and doing interact theoretically or methodologically with the overall aim of addressing questions with interrelated or linked components (Newell, 20I3, p. 3I). Because interdisciplinary programs involve the interaction of several disciplines, students in such programs are faced with communicating across diverse assumptions and practices (Brodin \& Avery, 2020). Interdisciplinary doctoral writers are tasked with synthesizing and negotiating ways of knowing and doing from several disciplines (Boden et al., 20II) - a particularly tall order when disciplinary language may be interpreted differently across borders (Choi \& Pak, 2007; Rogers et al., 2016).

This chapter reflects on contemporary imaginings of doctoral writing that seep into and deeply affect the everyday realities of interdisciplinary doctoral writers. My purpose is to interrogate the implications of taken-for-granted ways that doctoral writing is imagined in interdisciplinary life sciences doctoral programs (i.e., interdisciplinary programs focused on questions of biology and medicine, such as computational biology and biophysics) by focusing on writing that is not the dissertation. More specifically, I address the following questions: How is writing being imagined in interdisciplinary life 
sciences programs at the doctoral level, and what are the implications of these imaginings for doctoral writers? Further, and significant for the purposes of this volume, how do the experiences of doctoral writers provide insights that aid us in re-imagining doctoral writing?

This chapter begins with a brief review of insights generated by doctoral scholars about the nature of writing in doctoral programs and outlines the way in which I have found it productive to conceptualize writing. It then explores the experiences of doctoral students enrolled in interdisciplinary life sciences programs in order to generate further understandings of how doctoral writing is experienced and imagined in these contexts. The chapter concludes by offering suggestions about how student experiences and insights might indicate fissures in institutional assumptions for doctoral writing in interdisciplinary programs that could be re-imagined in order to better facilitate and navigate writing in interdisciplinary spaces.

\section{Rhetorical Genre Theory and Meta-Genre}

To understand how writing is imagined, I find it useful to draw on a concept that explores assumptions and imaginings about writing more generally. In Janet Giltrow's (2002) concept of meta-genre, which emerged from rhetorical genre theory, she conceptualized genres-kinds of writing such as journal articles, grant proposals, and conference papers-as emerging and evolving historically within specific communities to pursue those communities' specific goals, shape the identities of their members to pursue these goals, and (re) produce the community itself (Coe et al., 2002; Freedman \& Medway, 1994; Miller, 1984). Genres serve an important normalizing function within communities. As Anthony Paré (2002) has argued, the "automatic, ritual unfolding of genres makes them appear normal, even inevitable; they are simply the way things are done" (p. 59). Writing becomes hidden in plain sight because assumptions about writing are so routinized that we often fail to actually see them-we just inherit taken-for-granted rules about what writing is and what it does. The significance of this, of course, is that doctoral writing also gets trapped in normalized, common sense discourses of what writing is and what it does (Kamler \& Thomson, 20I4; Starke-Meyerring, 20II).

Meta-genres are repeated and regularized discourses that shape how we understand genres. Meta-genre, as conceptualized by Giltrow (2002), is "situated language about situated language" (p. 190) and can be understood as "atmospheres of wordings and activities ... surrounding genres” (p. 195). Social life is rife with meta-genres governing who can speak, when they can speak, what can and cannot be said, and so on. Sometimes, these rules are written down. In 
elementary school classrooms, a poster with classroom rules reminds students to raise their hands to speak. Other rules are never articulated but are learned through observation. Young children may never see the rule "don't interrupt others" written down, but through behavioral reinforcement they learn interrupting is against the rules of the classroom. If we think about the classroom as a kind of genre, the rules about raising hands and not interrupting can be understood as meta-genres governing how the classroom functions, regardless of whether they are ever explicitly articulated. In higher education, we can see traces of direct situated language occurring in policy documents, procedures, and guidelines that control and regulate genre conventions and expectations (Starke-Meyerring et al., 20I4). In fact, as Doreen Starke-Meyerring and her colleagues illustrated, policies and regulations about doctoral dissertations construct a particular idea of how a dissertation should be written and the nature of the writing itself, and these written rules can direct writers to produce the dissertation in a certain way. However, like the unwritten rules of elementary classrooms, the rules governing doctoral writing can also be unwritten.

To probe unwritten rules governing doctoral writing, I trace students' meta-talk to tease out unspoken assumptions regularized by meta-genres. Meta-talk is talk about genres and serves as an entry-point into the unwritten rules governing genre conventions and expectations. To return to my example of the elementary classroom, a teacher telling a student to use her inside voice is meta-talk regulating expectations about what volume is appropriate in the classroom. This meta-talk reinforces written and unwritten rules about when students can speak and what volume is appropriate in a classroom setting. In higher education and professional settings, this talk can be traced to written policies (e.g., institutional regulations) (McNely, 20I7). Eliciting meta-talk from doctoral students illustrates the kinds of regularizing conventions that dictate how writing is imagined. Exploring where meta-talk might be naturalizing "highly contingent practices" (Giltrow, 2002, p. 20I) offers an entry-point to examining how doctoral writers might resist or push back against imaginings of writing that sit uncomfortably, or don't fit at all, with their experiences writing in an interdisciplinary program.

Understanding meta-genres surrounding doctoral writing is useful because although writing is a normalizing force, it also has the potential to evolve, develop, and decay (Bazerman, 2000; Devitt, 2004; Schryer, I993). In looking at meta-genres surrounding interdisciplinary doctoral writing, there is the potential to expose what kinds of shifts, cracks, or tensions may be happening in how writing is imagined. Being aware of meta-genres that occlude or naturalize "highly contingent practices, may not be bad in itself, but, rather, a sign of unspoken negotiations among conflicting interests,"(Giltrow, 
2002, p. 20I). In other words, meta-genre may control what kinds of writing can happen and how they happen in such a way as to sweep any evidence of discord or disagreement under the rug. Furthermore, because rhetorical genre theory understands genres as sites of power and ideology (Coe et al., 2002; Paré, 20I4) where beliefs, assumptions, and practices are (re)produced, meta-genres indicate what kinds of common-sense assumptions are privileged and normalized. For my purposes, exploring the assumptions regulated by meta-genres in interdisciplinary life sciences doctoral programs is one way of understanding how doctoral writing is currently imagined and whether there are tensions or frictions that may indicate a meta-genre in conflict-and, thus, avenues for re-imagining writing in these spaces.

\section{Methods}

The data discussed here were generated from a larger study that explored writing in interdisciplinary programs at a Canadian research-intensive university where the study received approval from the institution's research ethics board. I interviewed students from a range of interdisciplinary life sciences programs-programs such as biophysics, computational biology, bioinformatics, and developmental biology. Researchers in these programs employ interdisciplinary approaches to health and medicine (e.g., cell development, cancer research, evolution). Although this study generated a number of data sets, here I am interested in the experiences of doctoral students to understand how written and unwritten rules about writing shape the way that writing is imagined. Because my focus is on how writing is imagined, students' experiences serve as an entry-point to more general assumptions about writing. The data reported here are drawn from a series of three semi-structured interviews with five doctoral students from three interdisciplinary programs: biophysics, computational biology, and developmental and evolutionary biology.

As a doctoral student myself at the time of the interviews (albeit one in education, not in science), my interviews with science doctoral students tended to evolve into extended conversations about writing and the doctoral process in general. I found that much of the talk elicited during interviews was meta-talk, rich with conventions, proscriptions, and taken-for-granted rules about writing. To trace meta-talk, I used the following framework based on rhetorical genre analysis guidelines (e.g., Devitt et al., 2004) to guide my analysis of interview data:

- How do students imagine writing in interdisciplinary programs? How do they talk about interdisciplinarity? 
- How do students understand the conventions of interdisciplinary writing? What proscriptions, warnings, or advice shape these understandings?

- How do students contend with possible variations of practices and beliefs across disciplines?

- How might meta-talk reveal frictions, tensions, or contradictions about interdisciplinary writing?

Meta-talk emerging from these interviews provided a means of understanding the discourses and meta-genres shaping students' encounters with writing.

Since my goal is to understand how institutional imaginings of writing shape doctoral students' everyday experiences with writing, I have made a conscious decision not to focus on individual students in this chapter. While I admit this does limit the depth I can provide about specific individuals, I am more concerned with what their experiences as a whole indicate about imaginings of doctoral writing. I have redacted potentially identifying information about participants and their research by inserting "[X]" where statements including this information would have occurred.

I should also note that, in response to recent calls for broadening understandings of doctoral writing (e.g., Paré, 20I7; Porter et al., 20I8), I do not limit my definition of doctoral writing to the dissertation. While certainly a milestone text within the doctorate, the dissertation comprises only one kind of writing that students I interviewed were expected to produce.

\section{Imagining Interdisciplinary Writing: Explaining and Translating}

As a starting point in discussing how interdisciplinary doctoral writing is imagined, I want to share some of the ways that doctoral students spoke explicitly about writing, often in response to my inquiries about the process of writing to a diverse disciplinary audience. Many instances of meta-talk emerged when I asked students about their writing directly, and, perhaps unsurprisingly, students shared very similar ways of articulating their thoughts about writing. Students seemed to use two ideas most often to describe what they were doing when writing within an interdisciplinary program: explaining and translating.

When I asked students about writing in an interdisciplinary context, many of them spoke about writing as a matter of explaining concepts clearly and simply. One student, talking about re-writing a section of a manuscript on computational methods while collaborating with a biology lab, emphasized 
the importance of explaining their approach clearly to readers:

I think it goes back to the idea of having to figure out how to explain the analyses and doing it in a way that's accessible to them so that they also understand ... what's being done to their data but also can point out if there's something that, in a biologically motivated way, doesn't make sense.

This statement suggests that, for this student, writing about a new computational approach for a new disciplinary audience was a matter of making it accessible. The writer's goal was to ensure that a method is described in writing in such a way that biologists can read it and understand what's being done to the data and in such a way that makes the explanation simple.

Students also seemed to understand writing in an interdisciplinary program as a process of translating. Often, writing to diverse disciplinary audiences was described as a process of taking ideas from one discipline and translating them for another by using different vocabulary or jargon. For example, one student stated,

I think the big challenge for me is I'm finding myself doing a lot of learning but also trying to translate all these ideas that I know are, like we were talking about earlier about having to ... there's like two entirely not necessarily overlapping vocabularies in these two areas, so it's been a lot of practice in learning how to communicate things I know and have used in my analysis in ways they will understand and also trying to incorporate the fact that they have a ton of biological knowledge that I am not coming in with.

In this case, where there are "two ... not necessarily overlapping vocabularies," writing was still positioned as a means of explaining one concept or idea; that is, the assumption appears to be that there are different disciplines but just one way of writing-doctoral writers need only use different words to describe the phenomena under investigation to interdisciplinary audiences. Writing, then, becomes a process of simply re-wording research so that it can be incorporated into other disciplinary approaches.

Speaking further on this process of translation, another student underscored its value as well as how integral the entire communicative process was to good interdisciplinary research:

And I guess my point is, I think that a lot of good interdisciplinary science, and I have a lot of-I think good interdisci- 
plinary communication, if it is clear and straightforward, then if there was an audience for actually reading this kind of stuff, the idea that these things face an actual barrier I think is a lot less. I think the barriers are kind of like when you read a developmental biology paper and-I mean some of them are really good, other ones are just crap. So especially if you read the crap ones, you're like, this is impenetrable, and of course you need some sort of translation [emphasis added].... I guess, if you're talking about-if you're trying to communicate this paper to someone else or something else, it's about ... translation's just that communication. I want to say, colloquially, it might be dumbing down? But I would also say it's cutting out the crap.

Again, this student positioned interdisciplinary writing as a matter of translation, as ensuring that ideas are as clear and straightforward as possible. Writing, here, is understood as being, on a fundamental level, the same no matter where students are writing or to whom (Berlin, I988). All of this talk suggests that interdisciplinary doctoral writing is imagined in a very specific way, one that does not view writing as being situated or value-laden but as taking ideas and knowledge from one discipline and transposing them, uncomplicatedly, to another. Characterizing interdisciplinary writing as simply translating or "dumbing down," however, can lead to challenges when this characterization prevents writers from imagining writing as "an explicitly rhetorical process" (Tardy, 2005, p. 336).

Indeed, students' talk about writing in interdisciplinary programs suggested that so long as they wrote clearly, explained well, and avoided overusing jargon, any member of their interdisciplinary community should have been able to read and understand their writing. This echoes what remains a dominant way of imagining writing in higher education. Writing appears, in theory at least, divorced from situation and inherited assumptions (Rose, 1985). Interdisciplinary writing is, in other words, imagined to be arhetorical: any writing a doctoral writer produces, no matter where it was written, who wrote it, or who will read it, has the potential to be understandable and readable if only students could write clearly, translate appropriately, and explain properly (cf. Nystrand et al., I993; Russell, 2002).

\section{Students' Meta-Talk Suggests Interdisciplinary Writing is Imagined Arhetorically}

Based on students' talk about writing, this practice is imagined as being separate from situation-writing, so long as it is done clearly, should be able 
to transcend disciplinary boundaries. Imagining writing in this way, that is arhetorically, places additional demands on doctoral writers. Most notably among these demands is how arhetorical assumptions about writing occlude the socially situated and non-neutral nature of writing. Arhetorical imaginings mask the rhetorical nature of writing in common sense assumptions, creating a paradox where writing should be easy, but where doctoral writers struggle in silence (Starke-Meyerring, 20II). For participants in this study, this paradox was particularly significant as dominant arhetorical imaginings of writing appeared to sit very uncomfortably with how doctoral students actually experienced writing in these interdisciplinary doctoral programs.

For instance, although much of students' meta-talk described writing as a simple process of communicating ideas to diverse interdisciplinary audience involving translating and explaining ideas as simply as possible, students also frequently complicated this. One student explained:

I feel there is not so much talk about what other writing there is than before the manuscript or before even the mini-publications like posters and stuff. And I find I tend to take really copious notes just on a daily basis and I think that helps clarify my thinking, but I don't-I have tried to ask, how do you do this? How do you think about your project? What's your process? And people don't give good answers! [laughs]

Framing interdisciplinary writing as translating and explaining occludes the rhetorical activity doctoral students must engage with; that is, it hides the social and situated nature of writing. Occluding meta-talk creates additional demands for navigating the diverse expectations of an interdisciplinary audience. When interdisciplinary students write, what they are producing is never as straightforward or simple as the dominant way of imagining writing. Indeed, the meta-talk produced by students suggests that writing should be simple, but it isn't. Meta-talk that promotes an imagining of writing as simple and clear is not unique to interdisciplinary programs (see Starke-Meyerring, 20II). Yet, the implications of such imaginings are significant for interdisciplinary doctoral writers: With the expectations of several disciplines occluded, students are left with few resources to articulate or negotiate diverse disciplinary expectations about writing.

Although the meta-talk students produced about their writing echoed what we currently know about how writing is imagined in doctoral education (Kamler \& Thomson, 20I4; Starke-Meyerring, 20II), there were several instances where dominant imaginings of writing did not seem to fit with how these doctoral students experienced writing. In fact, when students shared 
what they were actually doing when they were engaged in writing, they painted a substantially different picture than their meta-talk suggested. Instead of being a simple and straightforward process, doctoral students' experiences suggested that writing was often fraught and complex. The contrast between expectations about writing emerging from arhetorical imaginings and students' experiences indicates that interdisciplinary doctoral writing is a much more complex, situated, and non-neutral enterprise than students' meta-talk reveals (Bawarshi, 2003; Coe et al., 2002; Paré \& Smart, 1994).

Indeed, probing students' normalized assumptions about interdisciplinary writing revealed that this practice often involved tension and struggle. As the following excerpt illustrates quite powerfully, dominant assumptions that writing for interdisciplinary audiences is a matter of translating cannot account for the complex rhetorical work actually involved in writing to diverse disciplinary readers:

Student: I really felt the hardest part [of writing this article] was saying how [we] interpreted our results, like pinpointing "we saw this in the data and therefore we think this" about the tumour and how it originates.

Researcher: Why would that have been the tricky part?

Student: Maybe part of it is because our data, or I guess our logic, was we would study the normal $[\mathrm{X}]$ and try and use different computational strategies to match the tumour to the normal $[\mathrm{X}]$. So, there's no real-I think there was a lot, what is the word I'm looking for? There's a lot of precise pieces of information and logic to hold in your head. . .. I think maybe it just takes some background to interpret the results. So figuring out how to communicate that to the reader was hard.... I guess to go a little bit further, the idea of the project is we have these different $[\mathrm{X}]$ tumours, and we think they start in specific cell types $[\mathrm{X}]$, and each tumour type probably starts in a different type of cell, and the idea is to identify those cells. So, yeah, I guess it was making the leap from we say this match of this tumour type to this type of cell to this implies that this tumour starts in this cell type at this age and so on. I don't know if that makes sense, I think that's where I felt ... yeah.

This student described "making a leap" between different kinds of logic—that is, between different epistemological approaches to crafting an argument (see 
Tardy, 2005). In this case, it was not enough to simply take an approach used in computational research and translate to oncologists and biologists because it was not just the language that needed to change. Instead, the entire logical foundation for why the claim was valid had to be recast in terms and epistemic foundations that both biologists and oncologists could recognize. Thus, the student had to engage in the difficult process of transforming a knowledge claim. That is, for the claim to be accepted by an interdisciplinary audience, the student had to argue for the computational approach in a way that would be meaningful to a group of scientists with differently situated goals, interests, and values (cf. Blakeslee, 200I). The claim had to be fundamentally transformed in order for scientists from different disciplinary backgrounds to understand its value. The tricky part for writers, though, is that the process through which students engage in this argumentation is occluded by dominant imaginings of interdisciplinary writing as translating or as simple.

Because the rhetorical nature of interdisciplinary writing is hidden by dominant arhetorical talk, doctoral students were left without resources to engage in writing as a rhetorical process. That is, they were left without resources to see writing as a tool of constructing and arguing knowledge across disciplinary boundaries. Dominant imaginings of interdisciplinary writing forced doctoral students into difficult positions when they were expected to bridge disciplines by translating science and encounter fundamental epistemic differences between disciplines. Since students were left without rhetorical know-how (e.g., how to transform disciplinary knowledge), they had no way of negotiating or engaging with unfamiliar disciplinary audiences. As one student said,

To a certain degree I feel like I have to bridge [expectations]. But I also feel like it's a bunch of pretentious experimental biologists being pretentious. The first place I really found this out was when I had a discussion with a professor during my master's [program]. And he was an experimental biologist, and he articulated for the first time, really fully articulated, this idea in which you can't really know something unless you experiment, which is a bias in a lot of sciences.... I was like, you know, that's not right. Evolution was, at least for Darwin, not necessarily for Wallace, was sparked by the fact that a bunch of birds he took from Galapagos were identified as finches. That's not an experiment. That's an examination of reality and was formed by somebody who has an expertise in taxonomy which, by definition, you can't really experiment.

When faced with bridging expectations, this student encountered a funda- 
mental epistemological difference between the two disciplines for which they were supposed to be writing.

This difference was even clearer when a student talked about feeling some hesitation when collaborating on a manuscript with biologists because the way an analytical approach had been written into the paper seemed misleading:

They [the biologists] gave me a draft of the manuscript when they asked if I'd like to work on this project with them, and I thought the section, coming from a computational biology side, I didn't think it was - there were parts that were not accurate, I thought there were parts that were done incorrectly, and I also thought there could be more drawn out of the data. This part they especially agreed on, so part of-I would say I didn't necessarily need to be involved in the writing here. I really, in general I would say I enjoy writing and so I would have been happy if they'd asked. But also part of it was I didn't want my name on something that I thought was incorrect and I didn't want them to write up my results that they probably possibly didn't fully understand and to have that conflict. So I think I've really appreciated that.... It was tricky because when I first got a look at the analysis that had been done, I was like, oh, I'm not so sure about this, I would actually reconsider this. I know this is done a bit ... questionably.

The tension here became evident when this student, despite wanting to be involved in the project and wanting to write the accompanying manuscript, talked about not wanting their name on an iteration that seemed incorrect, where the biologists on the team had not fully understood a conflict in the paper.

This student's statement suggests that interdisciplinary doctoral writers are working within imaginings of writing where epistemic tensions are hidden. It suggests there is no room in interdisciplinary collaboration for conflicting ideas about how science should be written. Thus, writers are forced to work within a set of assumptions that positions science writing as tension-free and are forced to avoid producing writing that might pose a threat to colleagues (Myers, 1990). Based on this particular experience, it appears that doctoral writers are left trying to navigate conflicting norms and standards within a set of assumptions that "occludes or tactfully or timidly evades, or naturalizes highly contingent practices" (Giltrow, 2002, p. 20I). The way that interdisciplinary doctoral writing is imagined as translating and explaining hides the complex behind-the-scenes negotiations that go into writing 
in interdisciplinary programs. It also leaves doctoral students to shoulder additional demands because the rhetorical nature of writing is hidden. In this example, although writing with interdisciplinary colleagues should be easy, the student was resistant to putting their name to the manuscript without making specific revisions. This resistance indicates that beneath the surface, writing in interdisciplinary programs is fraught with tension and negotiation. Moreover, doctoral writers are often faced with confronting these tensions with limited access to or awareness of disciplinary knowledge and writing practices (Paré, 20II). As such, doctoral writers are left to face tension and conflict largely on their own.

The arhetorical nature of explicit meta-talk in interdisciplinary doctoral programs of course has consequences for how students understand writing and whether they are able to access and translate this discursive knowledge into practice (Giltrow, 2002, p. 190). But it also has implications for emerging scholars, for doctoral writers, in these programs. As Giltrow (2002) has written, meta-genre "may only reinforce insiders' mutual understandings while estranging newcomers from this consensus. And this may be especially so when students hear the same workings in different disciplinary contexts" (p. I96). In other words, because meta-genre has a powerful regulating power, it can prevent newcomers from figuring out what's really being regulated in the first place, especially if the meta-genre is reinforcing arhetorical assumptions about writing. For interdisciplinary doctoral students, this is especially worth noting because an arhetorical meta-genre, an arhetorical way of imagining writing, prevents students from translating "tacit know-how into discursive knowledge" (Giltrow, 2002, p. 190); that is, it prevents students from having rhetorical conversations about writing, conversations that could prove productive in navigating diverse expectations about and approaches to writing.

\section{Closing Reflections: Room for Re-imagining?}

To close this chapter, I want to turn to how interdisciplinary doctoral programs offer us a space in which to re-imagine doctoral writing. Students' meta-talk about writing, as I have illustrated, suggests strongly engrained meta-generic imaginings in interdisciplinary programs-ones that prefer to timidly evade tensions and frictions to maintain a façade of simplicity. But, as Giltrow (2002) suggested, in hiding what students are actually doing when they are engaged in writing, meta-genres prevent students from articulating tacit tensions in an explicitly discursive language. Arhetorical imaginings of interdisciplinary writing position the practice as deceptively simple, and, in avoiding the complex negotiation interdisciplinary writers seem to be doing, 
doctoral writers often struggle to articulate implicit knowledge. Students get stuck when they are forced to work within the assumptions that interdisciplinary writing is a matter of translating and explaining. Yet, as students pointed out, translating and explaining concepts were not enough to overcome tensions between different disciplinary expectations about writing and left them struggling to negotiate hidden rules that have developed in distinct disciplinary traditions. In short, the meta-generic imaginings in these interdisciplinary doctoral programs regulate an imagining of writing that actively occludes the tensions students encounter.

Given the consequences of these meta-generic imaginings, how might we begin to address them by re-imagining what doctoral writing is and does in interdisciplinary contexts? Students' experiences as reported in this chapter reinforce the need for supervisors and lecturers to, as Starke-Meyerring (20II) argued, "[recover] writing from its cloak of normalcy and ... [create] an environment for writing grounded in a solid research base" (p. 92). Instead of having students practice generalizing or translating, we might encourage them to argue the logic of their ideas and convince their collaborators of their claims. Students are more likely to benefit from being provided with research-based pedagogy that strips back arhetorical talk and illustrates the situated, value-laden, and social nature of interdisciplinary communication. This pedagogy might include instruction in how to acknowledge contradictions between disciplinary practices and might offer practical guidance on transforming claims and embracing the epistemic tensions accompanying interdisciplinary research. In fact, the research reported here indicates that meta-genre offers a useful way of pulling writing from the margins of doctoral work and confronting writers' hidden practices and assumptions. That is, developing a language that allows students and their mentors to articulate and reflect on normalized imaginings of writing empowers them to question and critique these propositions (Lingard \& Haber, 2002). Indeed, in talking to the doctoral students whose experiences I reported in this chapter, I noted that they became more aware of the contradictions and tension they encountered. Harnessing this awareness could be a critical way for students and their mentors to begin re-imagining doctoral writing as a social, non-neutral, and contested practice.

A re-imagining of doctoral writing might be facilitated by simply providing students and mentors with language that enables them to circumvent arhetorical imaginings. Doing so would make writers more aware of when they might be entering epistemologically fraught territory (Tardy, 2005) by peeling away arhetorical imaginings to confront the complex and unwritten rules students encounter when they negotiate disciplinary boundaries. Indeed, the concept of 
meta-genre has powerful potential to aid re-imaginings of writing experienced by students working towards their doctorate. Current imaginings of interdisciplinary writing avoid tension and contradiction- two features that are integral to interdisciplinary research itself. In order to engage productively with these tensions, students and their mentors need a way of talking about writing that does not avoid these features. When provided with prompts forcing them to think beyond normalized imaginings, writers are offered opportunities to "give accounts of themselves, and try to come to a situated understanding of their activities, their positions vis-à-vis one another, the risks incurred and indemnities afforded as they compose" (Giltrow, 2002, p. 203). By peeling back normalized assumptions, doctoral writers are more likely to be able to translate hidden rhetorical knowledge into tacit instruction. This ability is particularly significant for doctoral writers transitioning into faculty and mentorship roles. When such individuals are given opportunities to critically re-imagine writing in interdisciplinary doctoral programs, they are better equipped to aid their students develop important meta-knowledge.

The students that I encountered encourage us to ask about how we might make the tensions they experience productive-how we might start gently asking questions of how to introduce space within interdisciplinary doctoral programs for dominant imaginings to be re-imagined in order to provide interdisciplinary doctoral writers with the space and opportunity to thrive.

\section{References}

Aitchison, C., \& Guerin, C. (2014). Writing groups, pedagogy, theory and practice: An introduction. In C. Aitchison \& C. Guerin (Eds.), Writing groups for doctoral education and beyond: Innovations in practice and theory (pp. 3-17). Routledge.

Aitchison, C., \& Lee, A. (2006). Research writing: Problems and pedagogies. Teaching in Higher Education, 11(3), 265-278.

https://doi.org/10.1080/13562510600680574

Bawarshi, A. S. (2003). Genre and the invention of the writer: Reconsidering the place of invention in composition. Utah State University Press. https://digitalcommons. usu.edu/usupress_pubs/141

Bazerman, C. (2000). Shaping written knowledge: The genre and activity of the experimental article in science. The WAC Clearinghouse. https://wac.colostate.edu/ books/landmarks/bazerman-shaping/ (Originally published 1988, University of Wisconsin Press).

Berlin, J. (1988). Rhetoric and ideology in the writing class. College English, 50(5), 477-494. https://doi.org/10.2307/377477

Blakeslee, A. M. (2001). Interacting with audiences: Social influences on the production of scientific writing. Lawrence Erlbaum. https://doi.org/10.4324/9781410600097 
Boden, D., Borrego, M., \& Newswander, L. K. (2011). Student socialization in interdisciplinary doctoral education. Higher Education, 62(6), 741-755. https://doi. org/10.1007/s10734-011-9415-1

Brodin, E. M., \& Avery, H. (2020). Cross-disciplinary collaboration and scholarly independence in multidisciplinary learning environments at doctoral level and beyond. Minerva, 58, 409-433. https://doi.org/10.1007/s11024-020-09397-3

Choi, B. C. K., \& Pak, A. W. P. (2007). Multidisciplinarity, interdisciplinarity, and transdisciplinarity in health research, services, education, and policy: 2. promoters, barriers, and strategies of enhancement. Clinical and Investigative Medicine, 30(6), E224-E232. https://doi.org/10.25011/cim.v30i6.2950

Coe, R., Lingard, L., \& Teslenko, T. (2002). The rhetoric and ideology of genre: Strategies for stability and change. Hampton Press.

Devitt, A. J. (2004). Writing genres. Southern Illinois University Press.

Devitt, A. J., Reiff, M. J., \& Bawarshi, A. (2004). Scenes of writing: Strategies for composing with genres. Pearson.

Freedman, A., \& Medway, P. (1994). Locating genre studies: Antecedents and prospects. In A. Freedman \& P. Medway (Eds.), Genre in the new rhetoric (pp. 2-18). Taylor \& Francis.

Giltrow, J. (2002). Meta-Genre. In R. Coe, L. Lingard, \& T. Teslenko (Eds.), The rhetoric and ideology of genre: Strategies for stability and change (pp. 187-205). Hampton Press.

Kamler, B., \& Thomson, P. (2014). Helping doctoral students write: Pedagogies for supervision (2nd ed.). Routledge. https://doi.org/10.4324/9781315813639

Lee, A., \& Boud, D. (2009). Framing doctoral education as practice. In D. Boud \& A. Lee (Eds.), Changing practices of doctoral education (pp. 10-25). Routledge.

Lingard, L., \& Haber, R. (2002). Learning medical talk: How the apprenticeship complicates current explicit/tacit debates in genre instruction. In R. Coe, L. Lingard, \& T. Teslenko (Eds.), The rhetoric and ideology of genre: Strategies for stability and change (pp. 155-170). Hampton Press.

McAlpine, L., \& Amundsen, C. (2011). To be or not to be? The challenges of learning academic work. In L. McAlpine \& C. Amundsen (Eds.), Doctoral education: Research-based strategies for doctoral students, supervisors and administrators (pp. 1-13). Springer. https://doi.org/10.1007/978-94-007-0507-4_1

McNely, B. (2017). Moments and metagenres: Coordinating complex, multigenre narratives. Journal of Business and Technical Communication, 31(4), 443-480. https://doi.org/10.1177/1050651917713252

Miller, C. R. (1984). Genre as social action. Quarterly Journal of Speech, 70(2), 151167. https://doi.org/10.1080/00335638409383686

Myers, G. (1990). Writing biology: Texts in the social construction of scientific knowledge. University of Wisconsin Press.

Nerad, M., \& Heggelund, M. (Eds.). (2008). Toward a global PhD? Forces and forms in doctoral education worldwide. University of Washington Press.

Newell, W. H. (2013). The state of the field: Interdisciplinary theory. Issues in Interdisciplinary Studies, 31, 22-43. http://hdl.handle.net/10323/4478 
Nystrand, M., Greene, S., \& Wiemelt, J. (1993). Where did composition studies come from?: An intellectual history. Written Communication, 10(3), 267-333. https://doi.org/10.1177/0741088393010003001

Paré, A. (2002). Genre and identity: Individuals, institutions, and ideology. In R. Coe, L. Lingard, \& T. Teslenko (Eds.), The rhetoric and ideology of genre: Strategies for stability and change (pp. 57-71). Hampton Press.

Paré, A. (2011). Publish and flourish: Joining the conversation. In V. Kumar \& A. Lee (Eds.), Doctoral education in international context: Connecting local, regional and global perspectives (pp. 172-191). Universiti Putra Malaysia Press.

Paré, A. (2014). Rhetorical genre theory and academic literacy. Journal of Academic Language E Learning, 8(1), A83-A94. https://journal.aall.org.au/index.php/jall/ article/view/313

Paré, A. (2017). Re-thinking the dissertation and doctoral supervision/Reflexiones sobre la tesis doctoral y su supervisión. Journal for the Study of Education and Development/Infancia y Aprendizaje, 40(3), 407-428. https://doi.org/10.1080/0210 3702.2017.1341102

Paré, A., \& Smart, G. (1994). Observing genres in action: Towards a research methodology. In A. Freedman \& P. Medway (Eds.), Genre and the new rhetoric (pp. 146-154). Taylor \& Francis.

Paré, A., Starke-Meyerring, D., \& McAlpine, L. (2011). Knowledge and identity work in the supervision of doctoral student writing: Shaping rhetorical subjects. In D. Starke-Meyerring, A. Paré, N. Artemeva, M. Horne, \& L. Yousoubova (Eds.), Writing in knowledge societies (pp. 215-236). The WAC Clearinghouse; Parlor Press. https://doi.org/10.37514/PER-B.2011.2379.2.11

Porter, S., Young, L., Aarssen, L., Gibbs, R., Klein, R., Paré, A.,Ryoo, A., \& Wood-Adams, P. (2018). Report of the task force on the dissertation: Purpose, content, structure, assessment. Canadian Association for Graduate Studies. https:// secureservercdn.net/45.40.148.221/bba.0c2.myftpupload.com/wp-content/uploads/2018/09/CAGS-Dissertation-Task-Force-Report-1.pdf

Rogers, P. M., Zawacki, T. M., \& Baker, S. E. (2016). Uncovering challenges and pedagogical complications in dissertation writing and supervisory practices: A multimethod study of doctoral students and advisors. In S. Simpson, N. A. Caplan, M. Cox, \& T. Phillips (Eds.), Supporting graduate writers: Research, curriculum, and program design (pp. 52-77). University of Michigan Press.

Rose, M. (1985). The language of exclusion: Writing instruction at the university. College English, 47(4), 341-359. https://doi.org/10.2307/376957

Russell, D. R. (2002). Writing in the academic disciplines: A curricular history (2nd ed.). Southern Illinois University Press.

Schryer, C. F. (1993). Records as genre. Written Communication, 10(2), 200-234. https://doi.org/10.1177/0741088393010002003

Starke-Meyerring, D. (2011). The paradox of writing in doctoral education: Student experiences. In L. McAlpine \& C. Amundsen (Eds.), Doctoral education: Research-based strategies for doctoral students, supervisors and administrators (pp. 7495). Springer. https://doi.org/10.1007/978-94-007-0507-4_5 
Doody

Starke-Meyerring, D., Paré, A., Sun, K. Y., \& El-Bezre, N. (2014). Probing normalized discourses about writing: The case of the doctoral thesis. Journal of Academic Language and Learning, 8(2), A13-A27. https://journal.aall.org.au/index.php/jall/ article/view/295

Tardy, C. M. (2005). "It's like a story": Rhetorical knowledge development in advanced academic literacy. Journal of English for Academic Purposes, 4(4), 325-338. https://doi.org/10.1016/j.jeap.2005.07.005 
Section Three. Re-imagining Doctoral Writers and Their Others 



\title{
Embodiment, Relationality, and Constellation: $A$ Cultural Rhetorics Story of Doctoral Writing
}

\author{
Matthew B. Cox \\ East Carolina University \\ Elise Dixon \\ University of North Carolina at Pembroke \\ Katie Manthey \\ Salem College \\ Maria Novotny \\ University of Wisconsin-Milwaukee \\ Rachel Robinson \\ Michigan State University \\ Trixie G. Smith \\ Michigan State University
}

\begin{abstract}
This essay offers cultural rhetorics as a methodological tool for re-imagining doctoral writing. We provide a range of stories-theories to constellate the varying steps of this re-imagined dissertation writing methodology and process. Specifically, we discuss origin stories; how and why we write in community, including the importance of honoring relations/hips and reciprocity as part of the research process; the necessity of a decolonial orientation to our work and the communities we engage with; and a reflection on the process as a whole, including our embodied experiences throughout the research and writing. We conclude by discussing how cultural rhetorics method/ologies can help scholars in any field reimagine the doctoral writing process as embodied, experiential, and personal.
\end{abstract}

This chapter may read and feel differently than much doctoral writing scholarship, largely because of our use of story as theory. Collectively, we decided 
to organize this chapter around stories for two reasons. First, story serves as a tool to narrate our relationality with each other and explain how the six of us, as authors, are connected to this work. Second, as scholars trained in cultural rhetorics within writing and rhetoric studies, story acts as a methodology for re-imagining doctoral writing. By this we mean story acts as a generative tool to understand the embodied experiences of doing doctoral writing and maps the relational learning that happens in doctoral writing (see also Naomi, Chapter 9, this collection). Laura Micciche and Allison Carr (20II) explained that graduate students are frequently expected to learn, "through repeated exposure and an osmosis-like process," how to write as scholars in the field (p. 485). Furthermore, as Marilee Brooks-Gillies et al. (2015) explained, the "invisibility of genre, voice, style, data presentation, active versus passive writing, structure, and epistemology in writing instruction often allow students to refrain from critically examining their presentation of information"(p. 2). Additionally, relationships developed via these repeated exposures to (often unexamined) models of writing in their disciplines are assumed to be central to teaching graduate students how to become doctoral writers. That is, even though it is assumed that doctoral writing happens in a vacuum and that writers are alone in producing scholarly writing, we know that the writing produced by doctoral writers is simultaneously influenced by their conversations and relationships with others: dissertation advisors, academic mentors, community participants, colleagues, and multiple other communities in which we reside (see Kelly et al., Chapter Io, this collection). The written product may be individually composed, but the process of writing is informed by the embodied relationships doctoral writers have with their education. Turning towards these layered embodied and relational stories, we narrate in this chapter what we call a cultural rhetorics re-imagination of doctoral writing.

We begin by providing an origin story for how and why we came together to compose this piece. Next, we explain cultural rhetorics as a methodological tool for re-imagining doctoral writing. We then provide stories dedicated to the varying steps of this re-imagined dissertation writing: getting started, writing in community, considering reciprocal research relationships, engaging in decoloniality, and reflecting on the process as a whole. We conclude by discussing how these stories can help scholars re-imagine doctoral writing as embodied, experiential, and personal.

\section{Our Cultural Rhetorics Origin Story: Re- imagining Doctoral Writing}

Before we discuss our cultural rhetorics re-imagination of doctoral writing, we need to share a bit about the impetus of this chapter, or what cultural 
rhetoricians would recognize as "our origin story." Origin stories are the experiences that go un-noted in many academic genres. Often, doctoral writers are trained not to share moments of research failure, of participant distrust, of academic burnout and the fueling of imposter syndrome. Yet, these are all experiences that we know happen in doctoral and postdoctoral work. Cultural rhetorics asks us to name these origin stories, acknowledging how all experiences shape our learning and writing. The origin of this chapter begins at Michigan State University, in the Department of Writing, Rhetoric, and American Cultures, where Trixie chaired the other authors' doctoral committees over a span of 13 years, supervising the research and writing of all of our dissertations. Trixie works and teaches in cultural rhetorics and queer rhetorics, which is part of what has united us in terms of our methods and topics of research-we all focus on communities that connect to our personal and/ or political lives. Furthermore, we have all worked in the writing center that Trixie directs, a center that also enacts cultural rhetorics through its practices and policies. These relationships to Trixie, to each other, to communal spaces, all have affected how we imagined our doctoral research and writing. It is in this space and through the methodological lens of cultural rhetorics that we were able to re-imagine what doctoral writing could be and do in the American academic field known as rhetoric and composition as well as in the various fields our individual research interests intersect with.

Readers of this essay may ask what value cultural rhetorics can have for doctoral writing that is not personal, embodied, or based on lived experience. To those readers, we say that this is part of our argument. We use cultural rhetorics to point towards the ways in which institutional value disregards the personal and embodied. Even if doctoral writers argue that their dissertations have absolutely zero personal influence upon them, writers are attached to their dissertations due to the physicality of writing them. Often, though, we find there is a general scholarly dismissal of discussing embodiment by labeling embodiment as antithetical to rigorous scholarship:

Work about/on/with embodiment can sometimes be written off as self-absorbed-academic navel gazing. But this is a misstep because scholarship about/on/with embodiment works to continually remind readers, writers, researchers, and pedagogues that bodies matter to the paradigms, perspectives, relations, and decisions one has in a given situation. (Smith et al. 20I7, p. 46)

Such a statement emphasizes that there is an embodied, affectual component in the writing process. As such, to not tend to that component is to not un- 
derstand the processes that inform the doctoral writing that is formally produced. We use cultural rhetorics in this chapter, then, to call attention to how the teaching of doctoral writing often erodes tending to the personal, embodied, and relational processes that inform the very writing that is produced.

In what follows, we define cultural rhetorics as a methodology. We focus on methodology as we reflect on Kate Pantelides' (2017) suggestion for "graduate students to use methodology sections as starting points for conversation with faculty" to ease the anxiety and "significant pain" that is often experienced with doctoral writing (p. 210). Taking up this suggestion, we discuss what a cultural rhetorics methodology is in order to re-imagine how we may better prepare future doctoral writers, doctoral mentors, committee chairs, and tutors of doctoral writers. This re-imagination may help us in better attending to the formal written products expected of doctoral writing by better understanding the everyday, messy, and embodied relational experiences that complicate the production of doctoral writing.

\section{Cultural Rhetorics as Method/ologie/s}

This collaborative essay uses cultural rhetorics method/ologie/s, practices, and theoretical frames in order to illustrate the argument we are making. We challenge the traditional humanities-based model of writing lengthy, text-only dissertations focused on secondary sources or primary texts such as novels (Welch et al., 2002; Pantelides, 2015). In addition, as teachers and researchers who have all worked in writing centers, we challenge one-sizefits-all models of dissertation writing processes and dissertation support. We focus instead on individuals - their writing processes, writing goals and purposes, disciplinary requirements and expectations, communities, and embodied experiences.

We see cultural rhetorics as a methodology "that recognizes and honors the cultural specificity of all rhetorical practices/productions," which includes an "understanding of the material bodies engaged in rhetorical practices" (Bratta \& Powell, 2016). Consequently, we pay attention to the embodied experiences of both being and guiding doctoral writers. We also build from what we see as four pillars of cultural rhetorics practice: story as theory; engagement with decoloniality and decolonial practices; constellative practices as a way to build community and understanding; and the practice of relationality or honoring our relatives in practice, which often includes acts and attitudes of reciprocity (Bratta \& Powell, 20r6; Powell et al. 20I4). We use the tenets of relationality and reciprocity to explore our experiences of planning, writing, and revising dissertation projects that use cultural rhetorics method/ologie/s and lenses to 
explore various communities and phenomena; we also explore the embodied experiences of being in the doctoral writing moment as well as what was taken from this moment into first jobs and becoming doctoral advisors ourselves. While each section is a telling of selected stories-theories, often they reflect similar themes of experience for all of us. We want to illuminate how each of us individually experienced our dissertation writing practices, but we also acknowledge how those practices were similar because they all reflected cultural rhetorics values of relationality and reciprocity.

Doreen Starke-Meyerring (2014) issued a challenge to those invested in doctoral education:

Help students understand why they find themselves in the situations they do; how research writing works to produce particular kinds of knowledge; what politics are involved; and how writing groups might work to push that knowledge work as well as the sedimented knowledge systems doctoral scholars are entering. (p. 78)

To answer this call and to embody a cultural rhetorics method of community theorizing, we drafted a series of questions for each other to help us frame our storytelling and conversations (see Appendix). We then worked from this set of stories-theories to constellate our experiences and identify patterns as well as takeaways. We found, for example, that the process was/is important to all of us, maybe even more important than the dissertation itself. Similarly, the relationships built, maintained, and lost with communities and individuals are a part of this research and writing process. As Marilee Brooks-Gillies and colleagues (2020) explained, doctoral writing is about learning and performing the literacies and expectations of the field and about developing scholarly identities. For us, this meant resisting traditional modes of writing and developing our identities as cultural rhetorics scholars. Enacting cultural rhetorics method/ologie/s is always about the practice, because communities are built through practices.

In what follows, we discuss the pillars of cultural rhetorics in the context of doctoral writing processes and include author stories ${ }^{1}$ to illustrate the experiences of composing formal pieces of writing. We do this to call attention

1 Many authors would choose to italicize stories in the text, but we do not in order to emphasize that they are indeed part of the theoretical and analytical text we are presenting. We do identify storytellers/theorizers in order to acknowledge individual experience. When we move from individual story to collective analysis, we provide an additional space with asterisks to indicate this movement. 
to how we might re-imagine our pedagogical approach-whether through peer mentoring, advising, or chairing — to doctoral writing projects.

\section{Getting Started: The Personal is Always Present When We Write}

Preparing to write a cultural rhetorics dissertation requires an emotional component that is not always a part of other writing processes. A cultural rhetorics dissertation often involves aspects of the writer's personal story, sometimes requiring writers to dissect parts of their own positionality (see also Fa'avae, Chapter 8, this collection; Naomi, Chapter 9, this collection). Identities that we carry with us are conflicting and complicated, causing our bodies to search for ways to embrace them or to hide or modify them. This process can be a point of additional struggle for many people who fall outside of the traditional white, cisgender, heteronormative identity markers. Devika Chawla (2007) described how her family's identification with physical dislocation could not be separated from her own academic identity, so she embraced both in her work; she noted,

I am a palpable presence in every essay that I have written because position, self, and identity (of the researcher and the participants) are, for me, recursive components of scholarly research. To be apart from what I do is alien to me. (p. I7)

Likewise, scholars such as Gloria Anzaldúa (2007), bell hooks (2015), and Judith Halberstam (1998) have written about how their multiple identities and voices have not always fit into the world and also how their writing and work cannot be separated from those identities and voices. According to hooks (2015), this experience requires the "radical standpoint, perspective, and position" of the politics of location, and she explained that enjoying her work alongside that of critical theory is only possible "because one transgresses, moves 'out of one's place.' For many of us, that movement requires pushing against oppressive boundaries set by race, sex, and class domination" (p. 203). This pushing results in crucial choices: Do we align and identify with the traditional heteronormative, colonizing ways that might be "right," or do we stand with the oppressed, the marginalized, and the struggling in order to make aware the experiences, and the knowledges, of others, or ourselves, in these positions?

How, indeed, do we push against the narratives of the straight and narrow to hear the stories, to practice the ways, to acknowledge the bodies of those outside? In many ways, this is a physical choice as much as a mental choice. 
We must choose which place to stand, which place to position our material bodies, and, therefore, which stories our bodies tell and which voice(s) we use to tell those stories as we write.

\section{A Story from Elise}

I didn't know what my dissertation would be about when I began my Ph.D. I figured it would be something queer and multimodal, but I didn't know what that would look like. It wasn't until I worked on my comprehensive exams that it began to fall into place. The question I worked to answer was, "How can multimodality support queer and feminist rhetorics?" I know multimodal composing can and does support queer and feminist rhetorics, but I learned through my research the ways in which the concept of multimodality falls short. In particular, I began coming across works of indigenous and cultural rhetorics scholars who were clearly engaging multimodality in feminist and queer ways but who weren't using the term "multimodality." Instead, the work "spoke" for itself, and I started thinking about multimodality in terms of "making." I wondered what affordances come from thinking of multimodality in terms of making, especially for queer communities. I actually drew quite heavily from Maria Novotny's (2017) dissertation for building a framework around cultural rhetorics' considerations of making and for thinking about engaging with a community about their making practices. This is where the dissertation writing started for me.

\section{A Story from Rachel}

I came into my Ph.D. program with a huge sense of unbelonging. Despite my years of experience in the field, when I finally got into my doctoral program, I felt like I'd somehow slipped in unnoticed, gotten pulled in through some weird academic nepotism, and utterly fooled everyone around me. This was only compounded by the fact that I was taking classes after more than a decade since previously being a student and feeling very much "out-scholared" by my classmates. During my first semester colloquium class, I was listening to Malea Powell talk about time management and, if I'm honest, zoning out, living in my own head, but I snapped to attention when I heard her say, "Perfectionism is a tool of the patriarchy." At that moment, all my research ideas clicked. I'd been chasing an idea I had of a "perfect" Ph.D. student that didn't exist, and, in doing so, I'd been feeding my feelings to the academic "patriarchy" and getting feelings of imposter syndrome back. Not long after this, I started to see the intersections of imposter syndrome, emotions, and 
embodiments, and I quickly decided to run my ideas by my committee chair, Trixie, to see if they held steam. By February of my second semester in my first year, I had my committee completely formed and my dissertation topic pretty much planned out. I found that the more I kept articulating my ideas to friends and colleagues, the more I liked them and felt confident in them.

For the authors of this chapter, our dissertations are closely connected to our own personal histories and experiences and are built upon the personal histories and experiences of others. We all drew from our specific positionalities and encounters with the world. For instance, Rachel's scholarship draws on her embodied experiences as a woman who feels intense imposter syndrome in the academy. Elise's queer and cultural rhetorics framework draws from her lived experience as a bisexual woman trying to build queer community in and outside of the academy.

For most of us, our initial process of planning our dissertations began with assuming our communities had developed cultural practices over time through storying and through making, practices that could teach us something about those communities, ourselves, and our discipline. In essence, as Powell et al. (2014) argued, "All cultural practices are built, shaped, and dismantled based on the encounters people have with one another within and across particular systems of shared belief" (So, What Is Cultural Rhetorics? section, para. 4). We were interested in the shared belief of the communities with which we chose to engage-woman writing program administrators for Rachel and members of the activist organization the Lesbian Avengers for Elise, for example. We approached our work with the understanding that "the project of cultural rhetorics is, generally, to emphasize rhetorics as always-already cultural and cultures as persistently rhetorical. In practice, cultural rhetorics scholars investigate and understand meaning-making as it is situated in specific cultural communities" (Powell et al. 20I4). As our dissertations developed, we worked to follow our participants' lead, and we found that our personal connections to our writing was heavily influenced by our relationships with those communities.

\section{Community: Acknowledging Our Histories and That Our Research Is Personal for Us and Our Participants}

Taking a cultural rhetorics approach in our work means that we have to be very deliberate about acknowledging where our approaches and tools come from. For instance, cultural rhetorics has roots in Indigenous, Latinx, and 
decolonial rhetorics-among others. As scholars who are not Indigenous or Latinx, it is fundamental for us to acknowledge these foundations and carry them forward properly and respectfully. For all of us, this led to some personal doubt because of our awareness of the implications and responsibilities of our work for our research participants and those who might learn from our work. As we worked to enact methods of care in the/our own communities with whom we were working, the responsibility of that work could be painful at times. In this section, we share individual experiences of personal doubt faced through our writing process and community engagement.

\section{A Story from Elise}

By the time I interviewed my first participant, I was I4 weeks pregnant. I didn't look pregnant, and I never said I was, but each day after my interviews and archival research in New York City, I would take the subway back to my friend's apartment and nap, drink milkshakes, and barf. My body had its own needs, and they had nothing to do with the Lesbian Avengers.

My final interview was over the phone, and it was a little more than three weeks after my baby, Lane, was born. In that interview, a participant asked me how I identified, and I was honest. I was relieved for at least one participant to know I was bisexual-it's not a secret, but I wonder how they might feel to know I'm married to a man. Would they tell me the same things? It was never supposed to be a secret, but I felt incredibly strange about telling them my relationship status and about my pregnancy and baby. In many ways, I have lately been feeling the least queer I ever have. I fit into so many heteronormative stereotypes as a mother and wife. I'm so far from a lesbian activist, it's embarrassing.

My life experience, as it drifts further from the queer activists I work with in my dissertation, has left me doubting whether my positionality gets in the way of the work I do. I just recently sent a chapter to my participants, admitting to them that I had a baby, which is why my writing was coming to them so slowly. One of my participants congratulated me. The other two didn't acknowledge it. In some ways, I was relieved; some of the Lesbian Avengers had children (one of my participants included), and perhaps they don't see children as antithetical to queer positionality as I sometimes do.

What I have learned from my cultural rhetorics orientation to this dissertation is that writing is always relational, even as (and perhaps especially when) our relationships seem strained and distant. I am constantly thinking about my relationship to and with my research participants: how I relate to them, how they see me or trust me, whether or not I am doing their lives 
justice as I record their stories. If I weren't thinking about these insecurities, I'm not sure I would be doing cultural rhetorics.

\section{A Story from Matt}

Growing up as a gay kid in an overwhelmingly white small town in Indiana in the r 980 s meant that I was acutely aware of not being like other boys and pretty much nothing else. ${ }^{2}$ It didn't occur to me that I was also white, (lower) middle class, able-bodied, and (bodily/height/weight/stature) male because everyone else was also many of these things. Being these things wasn't something that stood out. But being an effeminate/gay/"sensitive" boy was something I couldn't escape. So, by the time I went to college and entered early adulthood, I absolutely felt like I inhabited a minoritized body. I worried about my safety. Being judged. Verbally assaulted or worse, physically harmed for being gay or perceived as "not manly enough." It wasn't until I began to travel and expand my friend and acquaintance group and to get to know folks of other racial, ethnic, dis/ability, religion/faith, gender identity, etc. backgrounds that I began to realize that I did really indeed have privilege based on having a white, male, middle-class body. So much of my late 2 os through my 3 os and now 40 s has been about owning and acknowledging that privilege. In fact, with the opening up/out of the queer/LGBTQIA world, being a gay, white, middle-class male has never seemed more "run-of-the-mill." And yet, often, I do still think about how I will be perceived or treated or judged.

This is where I am now as a researcher and writer and advisor to new doctoral writers. I try to find balance but also embrace the messiness. Intersectionality and constellatedness are really messy and complex. It's not just about one-dimensionally claiming, "I'm in a minority too! I'm oppressed!" but it's also not the "oppression Olympics" where we all compare notes and try to figure out what bodies have been the most marginalized. It's about saying, here are the intersections and here are the places we connect and the other places where we have to learn and teach each other. But as my mentors in my graduate work taught me, all I could do was be transparent in my approach and in my words, acknowledging the scholars and work from which I draw. This approach has served me well all these years, and I try to

2 The house style for the WAC Clearinghouse is to follow the general (although still emerging) guidance regarding capitalization of proper nouns related to racial and ethnic groups provided by the American Psychological Association (https://apastyle.apa.org/style-grammarguidelines/bias-free-language/racial-ethnic-minorities). The authors of this chapter have rejected this approach, noting that they view not capitalizing white as "an anti-racist move against white supremacy” (personal communication with Trixie Smith, June 2, 2021). 
pass it on in my mentorship. Even if it means the uncomfortable moments of admitting I have so much to learn.

Cultural rhetorics method/ologie/s require us to check in with ourselves alongside our participants. It also requires a conscious recognition of the individuals and communities we are constellating knowledge with-those we talk to, research with, read throughout the process. Again, we come back to the four pillars of cultural rhetorics and our use of them as approaches to re-imagining doctoral writing as we constellate thoughts about our research communities with ideas of relationality and reciprocity as well as decoloniality. As noted, we use these terms and practices rooted in Indigenous paradigms to acknowledge where and on what we build and also to acknowledge that they aren't just metaphors, but that they are actual making practices instrumental to the way we do cultural rhetorics research and writing, ${ }^{3}$ acknowledging that we are working with real human beings who may both celebrate and suffer the material consequences of our research and storytelling.

\section{Relationality and Reciprocity: Honoring People and Their Stories, or Showing That We Care}

In his chapter titled "Relational Accountability," Shawn Wilson (2008) explained that how we conduct our research, what method/ologie/s we use, determines how we uphold our relational accountability: "We are accountable to ourselves, the community, our environment or cosmos as a whole, and also to the idea or topics we are researching. We have all of these relationships that we need to uphold" (p. Io6). Andrea Riley-Mukavetz (2014) further explained:

Through an indigenous research paradigm, respect, reciprocity, and accountability are not just things to do to be ethical, but a way to cultivate and maintain the relationships we form with people, spaces, land, and the universe. Clearly, to enact relationality and relational accountability is personal and communal. (p. Irз)

Thus, there is no singular definition or picture of reciprocity to point to. For the writers and mentors in this essay, this meant listening carefully to the needs of participants, brainstorming through possible actions and/or

3 For more on cultural rhetorics ideas of making and making practices, please see Andréa Davis (2011), Qwo-Li Driskill (2010), and Malea Powell (2002). 
products, and following through with intended outcomes. We hope, however, that examples from our work will illustrate instances of reciprocity in or through our projects and interactions with each other and with our communities.

We see reciprocity as anchored in care: care for each other; care for our participants and communities; care for our audiences; and in the instance of doctoral writing, care for our committees and colleagues. Trixie, for example, talked with writers about their personal processes and needs as they researched and wrote. How often did they need to meet? What kind of feedback did they need at particular stages? Did they want to share chunks of writing or fully formed chapters? These processes were different across writers and stages. She also worked to care for the stories and participants that were being shared with her.

\section{A Story from Trixie}

I often read and viewed raw data and helped my doctoral writers to talk/ think/code through the data and to make connections across participants as well as texts. I was experiencing much more of the story than appears in the final product. I also helped doctoral writers to think through how or what to give (back) to their communities as an act of reciprocity. As a cultural rhetorics scholar, as a mentor, as a human, it was important to maintain respect for these storied gifts-from both my students and their participants.

I know that the doctoral writers I work with practice care and reciprocity with me. I remember, for example, many instances of Matt and another grad student coming over to my house to meet about their work. They would take turns playing with or caring for my foster children while I met with the other about their research. They also gave me much-needed adult company when I was overwhelmed with the needs of new children.

This sense of care, respect, and accountability with each other as advisor and writer is magnified and expanded through the relationship(s) with communities and research participants. The cultural rhetorics lens makes us all acutely aware of our own positionality and the possible impacts of our work for all involved. We want to be respectful of and accountable to our participant communities while also being respectful and accountable to our disciplinary field(s) and readers. Seeking input from participants at every stage of the research process means they have multiple opportunities to revise their 
stories, disagree with our framing of their stories, and both give and retract their consent, ${ }^{4}$ possibly even withdrawing completely.

We also see reciprocity as attuned to the ever-changing needs of our participants as well as ourselves, the researchers. Attunement represents the contemplative principle of research because listening requires a subsequent process: contemplation about what is heard and then a formulation of a response. We cannot know, for example, how to stretch in the context of a research project unless we are attuned (to other bodies, to systems, to other researchers, etc.). Attunement is closely connected to elasticity because being attuned speaks to trust; slow research "is a long uneven process, and it develops within the context of carefully cultivated relationships of trust between researchers and participants"(Lindquist, 20I2, p. 649). So, in many ways, attunement provides opportunities for researchers to listen and contemplate moments that are hard to predict in doctoral writingthe need for patience, or knowing when to stop, start, or hold off on a project.

Contemplating holding off on a project, when connected to doctoral writing, can be scary. Maria remembers a time when her dissertation almost came to a halt because of a participant's concerns.

\section{A Story from Maria}

As a graduate student trying to practice reciprocity, I frequently shared drafts of my dissertation chapters with my participants to ensure that the way in which I was representing their infertility stories was accurate and respected what they were willing to share. Yet, as I was finishing my dissertation and preparing my job market materials, which included writing that related to my participants, I realized that I should share those materials with my participants, too. So, in the fall of 2016 , I sent out an email to all three participants explaining the way in which I would be sharing their stories for the academic job market. Naively, I thought each participant would warmly write back, "This is great!" However, no such responses were ever returned. In fact, one participant-Meg-had deep concerns, writing that she had no knowledge that I would be using her story beyond my dissertation chapter.

Meg's response caught me off guard. Never did I anticipate how angry and frustrated she would feel by my act of sharing academic job materials. I thought my reliance on cultural rhetorics methodology would ensure that I was doing ethical research. Feeling overwhelmed and like I had failed in practicing cultural rhetorics, I turned to Trixie for help. Talking with Trixie, I

4 For more on cultural rhetorics and queer approaches to consent, see the work of Kathleen Livingston (2015). 
realized that practicing reciprocity in a research project may change over time and require different practices for different participants. For example, I explained to Trixie that throughout the writing of my dissertation, Meg's identity with infertility changed and evolved. She also became more protective over her story. My intention in sharing the job market materials with her was to ensure she felt protected. Yet, such an intention was clearly misunderstood and was not experienced as practicing reciprocity.

Maria's experience was a research lesson that we often don't write about in our formal doctoral pieces. Today, Maria is a faculty member who mentors graduate students. She also teaches courses about research methodologies and advises graduate dissertations. In these moments, she finds herself talking about Meg as a way to make her own moments of learning visible to her graduate students. Too often, we do not make these research lessons apparent in our publications and in our conference presentations. Yet, we believe that re-imagining doctoral writing processes requires us to attune ourselves to the stories we do not tell in our research. We must ask why we often don't write about the processes that went wrong in our work. Why must we always write about the successes? How may we better prepare doctoral writers when we write about what goes wrong in our research? Asking these questions may lead us towards new insight into what it means to be a doctoral writer.

\section{Decoloniality: Checking Our Privilege, or Acknowledging Our Embodied Experiences and the Land on Which We Research and Write}

Actively working from a position or orientation of decoloniality, or anti-coloniality, is a large part of a cultural rhetorics methodology, particularly for white scholars working on Indigenous land. ${ }^{5}$ To actively and radically resist

5 We understand that many would say we are using decolonial(ity) as metaphor here (Tuck \& Yang, 2012), which is why we want to label our method as a decolonial orientation. We support Indigenous and ally work towards land redress and recognitions of sovereignty and work against token claims of decolonialism that are meant to assuage settler-colonial guilt and white fragility (DiAngelo, 2018). Following Indigenous scholars such as Malea Powell (2002), Andrea Riley-Mukavetz (2014), and Qwo-Li Driskill (2010), we assert that paying attention to actual bodies in the academy and in the world (Indigenous and other) is one method of changing our orientation towards individuals and communities, particularly in our research and writing, and, thus, one way of beginning to right historical wrongs. 
notions of coloniality-in our publishing practices, in our data-gathering practices, and in our subject matter-means that we, as academics already possessing many privileges, continuously examine those privileges and use them to break apart colonized/r notions in our academic embodiment. As Qwo-Li Driskill (20I5) explained, "Decolonial skillshares work to ensure that the information and knowledge generated through scholarship do not remain within the academy or only disseminated through academic circles" (p. 64), and decolonial practice (and pedagogy/methodology) becomes a way for allies to "link arms together" (p. 59) as well as a method for healing trauma, maintaining cultural memory, and sharing knowledge.

For Katie and Rachel, one way we've attempted to enact decolonial practice is to focus our dissertations on bodies - physical and emotional — and the stories and sometimes new identities that emerge from those bodies. Maureen Johnson and colleagues (2015) argued that rhetoric and bodies cannot be separated and that we must consider physical, material bodies in meaning making; they noted that

the physical body carries meaning through discourse about or by a body. But embodiment theories suggest that meaning can be articulated beyond language. All bodies do rhetoric through texture, shape, color, consistency, movement, and function. Embodiment encourages a methodological approach that addresses the reflexive acknowledgement of the researcher from feminist traditions and conveys an awareness or consciousness about how bodies-our own and others'-figure in our work. (p. 39)

To illustrate this point, each author takes moments to explain the ways their own bodies-marked by size, age, infertility, and so on-affect their work. Their bodies help to create their identities because their bodies make meaning and hold signifying power. Our material bodies tell stories and they let people know - they signify — the otherwise hidden links we might carry to particular groups, be those linguistic, cultural, or historical, among others (Johnson et al., 2015). Johnson et al. (2015) created a definition of how embodiment practices "encourage complex relationships among past, present, and future, as well as across multiple identifications" (p. 42). The ways we inhabit our bodies in spaces and times-our embodiments-create our identities. Embodied knowledge influences embodied rhetorics to create "the purposeful effort by an author to represent aspects of embodiment within the text he or she is shaping" and acknowledge how those circumstances "affect how he or she understands the world" (Knoblauch, 20I2, p. 58). Though A. Abby 
Knoblauch (2012) used embodied rhetoric to explain only the ways authors must incorporate bodies in their writing, we would argue also that embodied rhetoric moves outside of the literal text on the page to consider all the ways individuals and communities compose meaning.

\section{A Story from Katie}

When I was working on my dissertation, I remember someone making the comment that work about personal trauma (e.g., "a therapy dissertation") was less rigorous/valid than more traditional topics of scholarship. Yet cultural rhetorics makes space for work that is deeply personal and sees it as part of the decolonial process. As Anzaldúa (2007) explained, when people are turned into objects—or distanced from themselves- there is space for violence. The personal is valid and valued because it is part of what makes a community. The personal lives in the body. As scholars working with personal topics and communities, we all experience this work differently. Writing my dissertation gave me space to examine my own biases around acceptable bodies and beauty and to search out other opinions. I was able to gather a group of theorists who helped me understand and explain why conventional beauty norms are rooted in colonialism and perpetuated on and through bodies. I was able to write back to my former self (and my ex-husband) and explain to them why and how our ideas were harmful.

This process of recognizing, undoing, and creating something new took a lot out of me emotionally. Many of the experiences that contributed to my interest in beauty norms were traumatic. Writing the dissertation was like stretching a muscle that hadn't been used in a long time. That growth, though, has stayed with me long after the dissertation and has been a big part of who I am as a teacher, scholar, and human today.

\section{A Story from Rachel}

When I was beginning to think of my research trajectory and plan out my comprehensive exams, my mother suddenly passed away. While I'd not yet begun writing my dissertation at that time, I knew I was going to be writing about emotions and bodies in academia. When I returned to school after her funeral, I was surprised to notice that my mother's passing and my subsequent grief affected everything about my research. Not only did my emotions feel forever altered, but also my physical body didn't cooperate with me anymore. When I tried to tell myself I should be writing or reading, my body rebelled with extreme exhaustion and crying. However, part of my own self-preserva- 
tion during this time was to acknowledge what my body needed, sometimes to just get through the day. Looking back, I realize that this acknowledgment was a decolonial practice. I was actively working to deconstruct the narrative around me of a "grieving graduate student" by publicly, and bodily, embracing my grief and openly writing about it.

\section{Post-Process: Reflecting on the Doctoral Writing Process, or How We (Have) Move(d) Forward}

Next, we share stories from some of us in various posts beyond the dissertation writing stage who are now in positions to reflect on this moment and share our experiences. We re-examine our own embodied experiences both in and after the writing process moment, holding on to the lessons we have brought into our professional careers.

\section{A Story from Maria}

After defending the dissertation, I found that the most learning and significance I experienced was not in the findings of my data but in the methodological wrestlings that emerged in completing my dissertation. While I expected particular findings to emerge, I did not expect to have issues with the writing of the dissertation. For instance, how to represent my research subjects became a contested issue. How to ethically tell their stories, ensuring they felt accurately represented. How to ensure my methods did not evoke a sense of recurring trauma for each of my participants as they recounted episodes of reproductive loss. All of these instances felt more pressing to discuss than the actual data findings. Many assume that the Institutional Review Board process mitigates these ethical conundrums. But the reality is, when working with human participants, research gets messy. As such, when I mentor students - whether undergraduate or graduate-I meet with them regularly to talk about the research process just as much (if not more than) the actual writing. Often in writing studies, we emphasize the writing process over product. I'd like to offer the idea that research is just as much of a process, yielding unpredicted and generative moments of learning.

\section{A Story from Matt}

When writing my dissertation, and really almost all my graduate-level writing, I used cultural rhetorics ideas of constellatedness-patchworks of my own experiences and identities. Already, completing a dissertation seemed 
like such a high-stakes activity, so deviating off of prescribed ideas of form and content seemed inadvisable. But also, as a queer person, such deviation seemed necessary to survive, to breathe, and to be myself. I had a dissertation chair and mentor(s) who gave me that space. When I graduated and went into a tenure track position, I began advising other graduate students (especially Ph.D. students). I approached my own writing and projects (for my tenure plan) and their writing (seminar work, dissertations, etc.) in the same queer, space-taking way I'd seen that suggested "living dangerously" in terms of breaking out of prescriptive, current-traditionalist molds was not only desirable but was necessary with cultural rhetorics method/ologie/s. Cultural rhetorics teaches us that failure (beings outside of "normal/ normativity") is human (Powell et al., 20I4, p. 20-2I), but being queer also teaches us that failure is even desirable. The embracing of failure is what allows creative space ... theoretically, epistemologically, methodologically (Ahmed, 2006, p. 25). So yeah, I braced myself for a failure that never came and for failures that already always were. Queer folks brace themselves for a harsh world, where just being queer is already a failure (see further queer conceptualisations of failure in Ingram, Chapter I3, this collection). My experience post-graduate writing is a continuation of that same approach: It will be a mess. It will sometimes (often) fail. That is the way in which you will most vividly and cathartically grow into who you were seeking to become on the journey.

What did we learn from our doctoral writing? It's messy. There will be failure. Failure is both the foundation and the journey, and the journey changes you. Community is vital to this journey, but being yourself and going inside yourself to figure out what and who you're becoming is related to that ability to seek outwardly. This knowledge also carries you into the future as you relate these lessons to your own students and the new communities you become a part of.

\section{Conclusion: Insights, or Re-imagining Doctoral Writing via Cultural Rhetorics}

We have offered a series of short vignettes to illustrate the various stages and processes of learning how to become doctoral writers - and eventually, scholarly writers. Such stories are rarely told and shared, perpetuating a narrative that the doctoral student must already be a master writer. As scholars in writing studies, we know this narrative is false. We know writing is a process, that 
it takes time to master the genres of one's discipline and to figure out how to discuss and make coherent one's scholarly findings in a synthesized text.

Our stories are therefore process-focused, offering insight into how we learned and how we mentor doctoral writing. Elise and Rachel's origin stories contextualize how to navigate life experiences while being consumed by the ominous pursuit of the dissertation. Being transparent about the uncontrollable moments of life led the two of them to form a relationship that continues today and offers a unique experience of doctoral peer-mentoring. We know from writing center scholarship that peer mentoring around writing assists students in practicing the language of talking about writing. Such a practice is rarely emphasized in doctoral writing. Yet, peer mentoring in community through the writing process is an invaluable and often understated practice that can continue throughout one's scholarly trajectory. For instance, Maria and Katie began talking with each other about their respective writing processes during the dissertation phase. Today, as scholars in their field, they continue to talk together as they approach book and journal projects.

In this sense, cultural rhetorics engages in the practice of community-building. While this occurs through the relationships between doctoral writers, it also happens with the communities we study. Elise's story about how to be transparent about her own positionality with the Lesbian Avengers is one such example of what community-building looks like in practice. Similarly, Matt's story emphasizes why transparency is essential to the communities we work with and offers an embodied model for demonstrating transparency to his own graduate students.

In practicing transparency, relationality and reciprocity emerge. Trixie and Maria's stories both touch on the need to train doctoral writers to examine what reciprocity means in relationship to their projects. For doctoral writers who work with communities and seek for their findings to have relevance in those communities, we must acknowledge that the actual dissertation may not be the by-product that has the most meaning. Instead, an alternative piece of composing may be a more valued product for the communities we work with. We see such a takeaway as a decolonial orientation to doctoral writing and one that has meaning across disciplines, especially as institutions seek to renew the public's investment in higher education. Cultural rhetorics helps us learn the practices that create the ethical relationship, the methods of listening, and the wrestling with how to represent these communities in our writing and what sorts of writing products will be of value to those communities. We see adapting a cultural rhetorics approach-whatever discipline one may identify with-as a valuable place to begin re-imagining doctoral writing. 


\section{References}

Ahmed, S. (2006). Queer phenomenology: Orientations, objects, others. Duke University Press.

Anzaldúa, G. (2007). Borderlands/La frontera: The new mestiza (3rd ed.). Aunt Lute Books.

Bratta, P. \& Powell, M. (2016). Introduction to the special issue: Entering the cultural rhetorics conversations. Enculturation, 21. http://enculturation.net/entering-the-cultural-rhetorics-conversations

Brooks-Gillies, M., Garcia, E. G., \& Kim, S. H. (2020). Introduction: Graduate writing across the disciplines. In M. Brooks-Gillies, E. G. Garcia, S. H. Kim, K Manthey, \& T. G. Smith (Eds.), Graduate writing across the disciplines: Identifying, teaching, and supporting (pp. 3-19). WAC Clearinghouse; University Press of Colorado. https://doi.org/10.37514/ATD-B.2020.0407.1.3

Brooks-Gillies, M., Garcia, E. G., Kim, S. H., Manthey, K., \& Smith, T. G. (2015). Graduate writing across the disciplines, introduction. Across the Disciplines, 12. https://doi.org/10.37514/ATD-J.2015.12.3.04

Chawla, D. (2007). Between stories and theories: Embodiments, disembodiments, and other struggles. Storytelling, Self, Society, 3(1), 16-30. https://www.tandfonline.com/doi/abs/10.1080/15505340709336689

Davis, A. D. (2011). Growing our discipline: An interview with Malea Powell. Composition Forum, 23. https://compositionforum.com/issue/23/malea-powell-interview.php

DiAngelo, R. (2018). White fragility: Why it's so hard for white people to talk about racism. Penguin.

Driskill, Q. (2010). Doubleweaving two-spirit critiques: Building alliances between native and queer studies. GLQ: A Journal of Lesbian and Gay Studies, 16(1-2), 6992. https://doi.org/10.1215/10642684-2009-013

Driskill, Q. (2015). Decolonial skillshares: Indigenous rhetorics as radical practice. In L. King, R. Gubele, \& J. R. Anderson (Eds.), Survivance, sovereignty, and story: Teaching American Indian rhetorics (pp. 57-78). Utah State University Press.

Halberstam, J. (1998). Female masculinity. Duke University Press.

hooks, b. (2015). Yearning: Race, gender, and cultural politics (2nd ed.). Routledge. https://doi.org/10.4324/9781315743110

Johnson, M., Levy, D., Manthey, K., \& Novotny, M. (2015). Embodiment: Embodying feminist rhetorics. Peitho, 18(1),39-44. https://cfshrc.org/article/embodiment-embodying-feminist-rhetorics/

Knoblauch, A. A. (2012). Bodies of knowledge: Definitions, delineations, and implications of embodied writing in the academy. Composition Studies, 40(2), 50-65. https://www.jstor.org/stable/compstud.40.2.0050

Lindquist, J. (2012). Time to grow them: Practicing slow research in a fast field. JAC: A Journal of Composition Theory, 32(3/4), 645-666. https://www.jstor.org/ stable/41709847

Livingston, K. (2015). Doing it all the time: A queer consent workshop. New Work Showcase: CWSHRCC 2015. https://newwork2015.cfshrc.org/livingston.html 
Livingston, K. A. (2015). The queer art $\mathcal{O}^{2}$ rhetoric of consent: Theories, practices, pedagogies [Doctoral dissertation, Michigan State University]. MSU Libraries Digital Repository. https://doi.org/doi:10.25335/M5RF24

Micciche, L. R., \& Carr, A. D. (2011). Toward graduate-level writing instruction. College Composition and Communication, 62(3), 477-501. https://www.jstor.org/ stable/27917909

Novotny, M. (2017). The art of infertility: A community project rhetorically conceiving failed fertility [Doctoral dissertation, Michigan State University]. MSU Libraries Digital Repository. https://d.lib.msu.edu/etd/4697

Pantelides, K. (2015). Dissertation genre change as a result of electronic theses and dissertation programs. Across the Disciplines, 12. https://doi.org/10.37514/ ATD-J.2015.12.3.05

Pantelides, K. L. (2017). Graduate students "show their work": Metalanguage in dissertation methodology sections. Journal of Technical Writing and Communication, 47(2), 194-214. https://doi.org/10.1177/0047281617692072

Powell, M. (2002). Rhetorics of survivance: How American Indians use writing. College Composition and Communication, 53(3), 396-434. https://doi. org/10.2307/1512132

Powell, M., Levy, D., Riley-Mukavetz, A., Brooks-Gillies, M., Novotny, M., \& Fisch-Ferguson, J. (2014). Our story begins here: Constellating cultural rhetorics. Enculturation, 18. http://enculturation.net/our-story-begins-here

Riley-Mukavetz, A. (2014). Towards a cultural rhetorics methodology: Making research matter with multi-generational women from the Little Traverse Bay Band. Rhetoric, Professional Communication, and Globalization, 5(1), 108-125.

Smith, T., Manthey, K., Gagnon, J., Choffel, E., Faison, W., Secrist, S., \& Bratta, P. (2017). Reflections on/of embodiment: Bringing our whole selves to class. Feminist Teacher, 28(1), 45-63. https://doi.org/10.5406/femteacher.28.1.0045

Starke-Meyerring, D. (2014). Writing groups as critical spaces for engaging normalized institutional cultures of writing in doctoral education. In C. Aitchison \& C. Guerin (Eds.), Writing groups for doctoral education and beyond: Innovations in practice and theory (pp. 65-81). Routledge.

Tuck, E., \& Yang K. W. (2012). Decolonization is not a metaphor. Decolonization: Indigeneity, Education and Society, 1(1). https://jps.library.utoronto.ca/index.php/ des/article/view/18630

Welch, N., Latterell, K. G., Moore, C., \& Carter-Tod, S. (Eds.). (2002). The dissertation and the discipline: Reinventing composition studies. Heinemann.

Wilson, S. (2008). Research is ceremony: Indigenous research methods. Fernwood.

\section{Appendix. Guiding Questions for Talking Circles}

- Describe your process for planning/researching/writing your dissertation. What types of interactions did you have with your chair, your committee, your colleagues during this process (as part of this process)? 
- How is your work indicative of Cultural Rhetorics? How did you enact Cultural Rhetorics methods/methodologies in your work and process?

- What did you predict about how you approach the dissertation process? What were the results of those predictions? Or, in other words, when did embodied moments alter your predictions? At what phase of the dissertation cycle?

- Whom did you speak with, consult with during the dissertation process? Why those people? In other words, who were the relations you depended on?

- If you define your dissertation as engaging in embodied rhetorics, why is this? Are you developing a theory about embodied rhetorics? Citing embodied rhetoricians? Working with bodies? In other words, how do we come to define our dissertations as involving embodied rhetorics?

- Did you feel as if your dissertation took a risk? Why is that? When did it feel risky - in the design, the writing, the disclosure? How did you measure that risk? Who mentored you as you took the risk? How was the risk "read" on the market?

- For those who have completed their dissertations, how have you used your dissertation for future writings/scholarship? What shape has that re-writing taken?

- Question for Trixie: What is your philosophy for advising dissertators? In what ways (if any) do you see your background in queer, feminist, embodied, or cultural rhetorics informing how you choose to advise?

- What was the most difficult part of writing your dissertation? OR/ AND do you think the most difficult part of writing the dissertation was internal (i.e., getting in your head, procrastination, etc.) or external (big life events, hectic schedules, etc.)? How were these difficulties embodied?

- Who did you feel were the key stakeholders in your writing throughout your Ph.D. process? How did those stakeholders change or get replaced over the years?

- What were your pains and pleasures of dissertation writing?

- In what ways was dissertation writing physical labor? Emotional labor?

- What guidance did you get at the beginning of the dissertation writing process from your stakeholders?

- In what ways did you find the dissertation writing process more isolating or community-building? 


\title{
Vā and Veitapui as Decolonial Potential: Ongoing Talatalanoa and Re-imagining Doctoral Being and Becoming
}

\author{
David Taufui Mikato Fa'avae \\ Te Kura Toi Tangata, Univerity of Waikato
}

\begin{abstract}
Ko e taumu'a 'o e tohi ni ke tau talatalanoa fekau'aki moe vā moe veitapui. This chapter is centered on vā and veitapui, Tongan concepts grounded in Indigenous Pacific philosophies linked to relational spaces. I articulate how the decolonial potentialities of doctoral being and becoming require intimate navigation and negotiation, highlighting the fluid, rich, and nuanced knowledges within vā and veitapui. Doctoral writing, as understood within vā and veitapui, provided a critical space for me to legitimize and value Indigenous Pacific thought in relation to dominant western knowledge. By employing Tongan concepts, I share how, through doctoral learning and writing, the encounters and experiences strengthened and affirmed my fatongia - an obligation and responsibility to honour and safeguard our cultural knowledges. For me, engaging in my own doctoral writing project was a matter of socio-political struggle and epistemic disobedience, because the academic traditions linked to perceived "proper" writing conventions were not what $\mathrm{I}$ adhered to in my own doctoral writing (McDowall \& Ramos, 20I7). In this chapter, I share how the concepts of vā and veitapui aided me in uncovering time-spaces within doctoral learning and education, and I re-imagine how Tongan ideas, language, and practices could be re-presented through writing.
\end{abstract}

Ko e koloa 'a e Tonga 'oku hā sino ia 'i he fakafōtunga 'o 'etau lea, fakakaukau, mo 'etau to'onga mo'ui pe ko hotau 'ulungaanga. For many Indigenous Pacific peoples, ${ }^{1}$ our ancestral knowledges are at the heart of who we are and

1 I use the term "Indigenous Pacific peoples" to refer to Indigenous people of Moananui-a-kiwa and their ancestral knowledges and languages. 
how we interpret and make sense of our worlds. It was not until my older sister and I started high school during the early ig9os in South Auckland, New Zealand, that we felt at odds with who we knew ourselves to be based on our home experiences and how we were perceived to be at school. What made it even more challenging for us was the fact that our own father's expectations of us were similar to those of our teachers. To my father, Tongan knowledge and practices had no place at school. His expectation was for us to acquire and excel in the English language. Western academic skills were of precedence. Tongan cultural knowledge and practice at the time, at least for my father, belonged at home. It was not until I started my postgraduate studies that I realized the significance of my ancestral knowledge to my success as an educator and researcher within higher education.

'E malava nai ke fakamamafa' $i$ 'a e lea Tonga mo e ngaahi fakakaukau 'a e Tonga 'i he mala'e 'ekatemika? Ko e tali ki ai - 'io. Indigenous Canadian scholar Margaret Kovach (2015) claims "incorporating an Indigenous worldview into a non-Indigenous language, with all that implies, is complex ... [and] is a troublesome task of crisscrossing cultural epistemologies" (p. 53), requiring more work than is often recognized by mainstream academics. In this chapter, to challenge the prevailing tendency to privilege western knowledge and language, I foreground lea faka-Tonga ${ }^{2}$ alongside concepts in doctoral education discourse. Within this text, I use lea faka-Tonga to intercept the dominant tendency to frame understanding and composition by predominantly relying on English concepts and language for meaning. Like Tongan scholars Linitā Manu'atu (2000) and Timote Vaioleti (20I6), I employ talatalanoa ${ }^{3}$ here to invite Tongan and Indigenous students and scholars to engage in this space of ongoing discussion about the ways in which we can appropriately draw from our ancestral knowledges and collaborate with each other to make sense of and honor our knowledge and language within academia. At the same time, this discourse will allow a wider audience to consider and appreciate what it means to live and work-with ${ }^{4}$ knowledge systems that are outside of their own. Hence, a fundamental question I address in this chapter is, "How can Indigenous students participate in doctoral education discourse yet draw from their ancestral knowledge systems and

2 Throughout this chapter, I use footnotes to provide translations and definitions. Here, lea faka-Tonga means the Tongan language.

3 Ongoing and continuous purposeful discussions

4 I use the term "work-with" to refer to intimate encounters that involve negotiating, honouring, and safeguarding Indigenous knowledge in research and actively seeking to learn from people and their cultural knowledge. 
re-present their framings through western modes of text like the thesis document?" 5 This chapter is part of an ongoing conversation and moves between languages-lea faka-Tonga and English-highlighting vā and veitapui, the fluid relational space where the re-imagining of doctoral writing can be used to empower and transform Indigenous Pacific doctoral students' thinking and practice. I have opted to use lea faka-Tonga in the form of questions or key points in most paragraphs to involve Tongan readers in the re-thinking and re-imagining of indigenous ideas in doctoral writing.

The narrow imaginings of doctoral subjectivity in the past has led to researchers paying increasingly close attention to doctoral education as a field of power relations shaped by gender, emotion, relationships, and care (see Burford \& Hook, 20I9; Grant, 2008; Hook, 2016; Manathunga, 2007). This chapter is an attempt to re-imagine the possibilities of doctoral writing that are often ignored by the academy itself. Moana ${ }^{6}$ academics have diverse views about the purpose of doctoral research. Many assume doctoral writing should mimic dominant western ideals and processes, epistemologies and ontologies. During my undergraduate study in the late I990s within the discipline of psychology, the norm at university (reiterated via conversations with my lecturers) was that researchers are distanced from what they are writing about. However, almost fifteen years later, during my doctoral study, the use of "Imy-we-us-our" in doctoral academic writing was encouraged and viewed as a significant practice of how "students [could] find their voice" (McDowall \& Ramos, 20I7, p. 56; see also Thurlow, Chapter 5, this collection) and how I could contribute new knowledge to the academy.

\section{Vā moe Veitapui: An Indigenous Worlded Philosophy of Relational and Inter-relational Spaces}

'Oku mahu'inga 'a e ngahi tefito'i lea ko e vā moe veitapui 'i he talatalanoa moe fakakaukau 'a e Tonga 'i he mala'e 'ekatemika. Tongan scholars 'Okusitino Mahina (2005) and Tēvita Ka'ili (20I7) developed the tā-vā theory within the field of social anthropology and Indigenous discourses to underscore spatio-temporal underpinnings and the fundamental view that time and space intricately co-exist and do not operate in isolation. This

5 Indigenous not only refers to those in the moana, but also refers to other minority students from other parts of the world who have been implicated by the colonial legacies of the west.

6 An individual whose positioning relates to Moana-nui-a-kiwa (Pacific ocean, or Oceania) and has heritage links to the ocean (moana) or Oceania (Moana) 
means that, in order to make sense of space, time must also be acknowledged when considering context. Churchward (2015) defined $v \bar{a}$ as the "distance between, distance apart" (p. 528). Figuratively, vā relates to the relational space or inter-relation(s) between people as well as between people and perceived inanimate objects, such as the land, ocean, or sky. As articulated by Carl Mika (20I7), Indigenous philosophies take on a worlded stance, where entities such as the land, ocean, and sky shape the process of how one comes to know oneself and, as such, are intimate parts of one's world and consequent world views. Through an Indigenous worlded philosophy, vā can also be used to understand the space in-between, in which people relate to and make sense of their ideas and concepts. Such inter-relations are believed to be spiritual and sacred in nature, as well as epistemological, because all things in the world are relational and intricately connected (Martin et al., 2020; Wilson, 200I).

According to Mika (20I7), this interconnection is critical to the relationship between Indigenous selfhood, knowledge, and the metaphysics of presence, with the idea of the metaphysics of presence referring to a tendency to want to seize a "stable truth," which frequently involves "grasping something objectively and holding it in place" (p. xi). This view contrasts with Indigenous worlded philosophies, whereby truth and the state of being are both "unknowable force[s]" comprising both "form and formlessness" and both "visible and invisible dimensions" (Mika, 20I7, p. xii). In other words, the concept of truth is "elusive, equivocal and context-dependent (time, space), encompassing both multiplicity and uncertainty" (Mika, 20I7, p. xii). When it comes to conceptualizing doctoral writing, I find Mika's speculative stance useful because it provides pathways forward for understanding the ways in which doctoral selves are fluid rather than fixed and very much dependent on multiple contexts in their formation. Two interrelated components of these contexts are tā and vā-time and space. My own experiences with becoming an Indigenous researcher have been (and continue to be) shaped by my experiences in New Zealand as a former secondary school teacher and experience in the wider Moana as a research fellow at the University of the South Pacific's Institute of Education. Thus, when I position myself as a "Tongan-born-in-Niue-raised-in-New-Zealand-with-Samoan-heritage," I do so in its entirety, meaning that all layers contribute to my sense of being and becoming.

Veitapui is a derivative of vā, and both are linked to spiritual and sacred relational spaces that are carefully cared for and nurtured, such as one's relationship with god or a spiritual being. When employing vā and veitapui to better make sense of relational spaces within doctoral education, they are 
applied using the principles of ' $\mathrm{ofa}^{7}$ and faka ${ }^{6} \mathrm{apa}^{6} \mathrm{apa}^{8}$. For instance, vā and veitapui can be used to understand the doctoral supervision space in relation to the relationship between students and supervisors, students and the mentoring space, and Pacific students' relational connections with other Indigenous groups within a shared space of learning and interaction. Learning how to navigate and mediate the relational connections within vā and veitapui leads to the honouring of knowledges and peoples. During monthly writing workshops for students supervised by my primary doctoral supervisor, I was able to learn academic writing skills as well as research knowledge from other more experienced doctoral students who had almost completed their projects. To honour the learning, I shared similar insights with other doctoral students in the department. Through vā and veitapui, these relationships enabled healing and the re-conciliation of the "self" in relation to Tongan culture, identity, and my fatongia ${ }^{9}$ to ensure the continuity and survival of Tongan cultural knowledge (Thaman, 1995). Indigenous scholars of Samoan and Tongan heritages have been the most prominent in theorising, framing, and applying vā through their writing (see Amituanai-Toloa, 2006; Iosefo, 20I6; Ka'ili, 20I7; Suaalii-Sauni, 20I7). Samoan scholar, Tamasailau Suaalii-Sauni (20I7) articulated vā as a social organising principle in the Samoan aiga ${ }^{\mathrm{Io}}$ and society, explaining that as a core idea associated with relational space, vā "governs all inter-personal, inter-group, and sacred/secular relations and is intimately connected to a Pasifika sense of self or identity" (p. I63).

Both vā and veitapui provide decolonial potentialities within doctoral education. By centering on Indigenous concepts like vā and veitapui as tools for theorisation, we may enable Indigenous students' capacity to develop confidence, know how to respond back to dominant western discourses, and deconstruct colonial thinking and practices that are embedded in research practices. This chapter offers an understanding of doctoral writing through vā and veitapui. It provides reflections of my doctoral journey in terms of the situations (encounters within the spaces) and inter-relations that challenged my thoughts and research actions and the subtleties and complexities when using an Indigenous and less formal method, for example, the talanoa method, in relation to more formal western semi-structured interviews in my doctoral study (see Fa'avae et al., 2or6).
7 Love
8 Respect
9 Obligations and responsibilities within the collective
10 Family 


\section{Tree of Opportunities Metaphor and the Hyphen (-): Re- imagining Doctoral Writing through Vāand Veitapui}

The "tree of opportunities" metaphor was developed in 200 I by Pacific educators and leaders in response to a desire to sustain Indigenous Pacific knowledges while embracing the global contexts of learning and education that were pervading the region at the time (Pene et al., 2002). The tree of opportunities symbolizes the coming-together of Indigenous Pacific leaders as well as the taking of ownership over providing opportunities to re-think education in response to ongoing changes related to modernity. In other words, the metaphor of the tree of opportunities provides a place for hyphenated work. I use the hyphen strategically here to indicate my desire to enable critical talatalanoa. The hyphen (-) provides a technical and symbolic vehicle for the idea of vā and veitapui by allowing connections to be established between fluid and nuanced ideas and processes that are inter-related.

However, the hyphen has its limitations. Samoan theologian scholar Faafetai Aiavā (20I7) articulated concerns with whether the hyphen could appropriately capture the lived realities of Pacific people in the diaspora. In his view, many scholars describe the hyphen as an in-between space that is linked to isolation rather than connection, particularly because Pacific people are diasporic, and he notes there is a tendency for New Zealand-born-andraised Samoans to feel dis-connected with their heritage roots and language in Samoa and thus to turn to the hyphen to symbolise their uneasiness and isolation. Mindful of misappropriation, in this chapter I use the hyphen to symbolise the ideas of vā and veitapui and to emphasise an ongoing negotiation that does not require one to "arrive at a [particular] destination" (Aiavā, 2017 p. 139). Specifically, I use the hyphen to enable a continuous yet critical talatalanoa. The "critical" within talatalanoa allows for an intimate interrogation of the similarities as well as the differences in-between, not favoring one or the other, but placing an emphasis on the entirety.

\section{Moana-Pacific-Pasifika: Context of My Doctoral Study}

'Oku fe'unga mo taau 'a e hingoa "Pasifika" ke faka'ilonga'i'aki 'a e Tonga 'i Aotearoa (New Zealand)? 'I he ngaahi talanoa mo e fatu tohi 'a Toketā Linitā Manu'atu mo e ni'ihi 'o e kakai Tonga 'i he mala'e 'o e ako ,na'a nau fokotu'u 'a e tefito'i kaveinga ko e "Fakakoloa 'a 'Aotearoa 'aki e lea Tonga, loto'i Tonga, mo e nofo 'a kāinga (Manu'atu, et al., 2or6) ke fakahā mai 'a e kehe 'a e Tonga mei he ni'ihi 'o e Pasifika 'i Aotearoa. The term Pasifika was coined by the New Zealand Ministry of Education (Samu, I998) as a 
way to group the diverse ethnic groups in New Zealand who have heritage roots to Moana-nui-a-kiwa. ${ }^{\text {II }}$ Outside of New Zealand however, the term Pacific is commonly used to represent the array of peoples and cultures from the Moana ${ }^{\mathrm{r2}}$. I use Pacific and Pasifika interchangeably in this chapter based on the contexts I reference, either within New Zealand or outside of New Zealand in the Moana - as it relates to the specific cultural knowledges and communities involved.

To help me capture the perceived currency of Pacific (and Pasifika) ancestral knowledges in schooling, during my doctoral studies I was advised to turn to the French philosopher Pierre Bourdieu (1977). Although Bourdieu did provide some critical insight via his theory of cultural capital, which refers to how some knowledges have more value than others, particularly in formal learning contexts, I found that much of his thinking and writing linked to cultural capital was framed primarily using western, Eurocentric concepts. For instance, Bourdieu's (1977) concepts of cultural reproduction and social reproduction provided an explanation for why palangi ${ }^{\mathrm{i} 3}$ students performed academically better at school, theorizing that their home knowledges were reproduced as formal qualifications. Yet, this assumed a view that schooling reinforced and privileged western forms of knowledge and learning, thereby marginalizing other knowledges. While Bourdieu's work gave me a point of reference, I found it contributed to deficit views of my Tongan ancestral knowledge in schooling. I chose to value Tongan cultural knowledge and emphasise the strengths in the intergenerational stories shared by the grandfathers and fathers with their sons and the ways in which such stories and experiences were operationalized by them in western schooling context (see

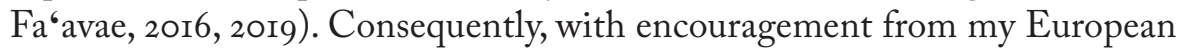
primary supervisor-an advocate for Indigenous knowledges-and Tongan secondary supervisor, tatala 'a e koloa 'a e to'utangata Tonga ${ }^{\text {I4 }}$ was developed as an approach to capture the process of unfolding intergenerational knowledge across generations of Tongan kāinga ${ }^{15}$ in Aotearoa ${ }^{16}$ and Tonga and as a way to ensure their cultural survival and continuity (Shipman, 1971; Thaman, 1995).
11 The Pacific Ocean
12 Oceania
13 A White person, often having European heritage
14 Conceptual framework linked to material wealth as well as knowledge and wisdom (shared valued cultural knowledges) within Tongan kāinga

15 Extended families

16 New Zealand 


\section{Navigating Doctoral Education Discourse and Honouring Indigenous Knowledge Within Research}

My doctoral study was centered on honouring Moana-Pacific-Pasifika and Indigenous knowledges, and in this chapter, I reflect on what it means to navigate the doctoral education space using Indigenous lenses, experiences, and frameworks like koloa 'a e to'utangata Tonga. 'Ana Taufe'ulungaki (2015), the former Minister of Education in Tonga, articulated koloa 'a e Tonga as follows:

Ko e 'uhinga ki he ngaahi tefito'i tui mo e fakakaukau 'a e Tonga, 'o kau ai 'ene ngaahi 'ilo mo e pōto'i ngāue, hono hisitōlia mo hono tukufakaholo, anga fakafonua mo. . .'ene lea fakafonua ... he ko e ngaahi tefito'i tui mo e ngaahi fakakaukau 'a e Tonga, 'oku taumu'a kātoa pē ki he tauhi 'a e ngaahi vā kotoape pē ke lelei, pea koloa'ia ai mo kaukaua mālohi, ma'uma'uluta, melino, feongoongoi, pea mo fe'uhi'aki 'a e nofo 'a kāinga. [Koloa 'o e Tonga refers to the core values and the ways of thinking of a Tongan, including knowledge and skills, its history and its inheritances, traditions and ... its language ... because a Tongan's values, beliefs and ways of thinking, all aims to maintain all relationships concerned to achieve prosperity and attain strength, harmony, peace, mutual understanding and interdependence within the extended family.] (p. 4)

Navigating how to write appropriately for the academy yet honor the re-presentation of Indigenous ideas and meanings requires ongoing negotiation within vā and veitapui. Doctoral education, as an international practice and field, is a "rapidly transforming, and increasingly uneasy area" (Burford, 20I6, p. 97). However, limited attention is paid to what doctoral education feels like for doctoral students (Burford, 20I6). In this chapter, I share my doctoral education learnings, experiences, and emotions. Through doctoral writing, I immersed myself in the ongoing training that Ailie McDowall \& Fabiane Ramos (20I7) referred to as the "tradition of formulaic [and] evidence-based writing" (p. 55) within the western academy; however, at the heart of the framing and re-framing of intergenerational cultural capital were Tongan ideas like koloa 'a e to' utangata Tonga.

'Oku mahu'inga 'aupito ke faka'apa'apa'i pea tokangaekina mavahe e tangata'i fonua 'o 'Aotearoa, pe ko e kāinga Māori 'i ha fekumi kotoa pē e fakahoko ' $\mathrm{i}$ he mala' $\mathrm{e}$ 'ekatemika fekauaki moe fonua ni. To relate to, main- 
tain, and honour connections with Māori, the tangata whenua ${ }^{17}$ in Aotearoa and in the wider moana, developing my position as a self-identified Indige-

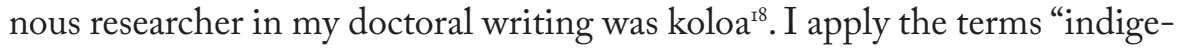
neity" and "Indigenous" in this chapter in relation to my position as Tongan/ Pacific/Pasifika with the critical intention to safeguard and honor ancestral knowledges. As such, my desire is to achieve self-determination by re-thinking and re-imagining doctoral research through Indigenous Pacific worldviews. Indigeneity or Indigenous are representative of my being and becoming an Indigenous researcher and academic (Martin et al., 2020) in multiple contexts across the diaspora of New Zealand and Tonga. Although Tonga was never officially colonized (Taufe ${ }^{6}$ ulungaki, 20I4), remnants of western systems and practices, symptomatic of its past relationships with Great Britain and New Zealand, are prevalent in Tonga's institutional and educational systems.

Decoloniality, or decolonisation, is a fundamental aim for Pacific or Pasifika doctoral researchers working-with Pacific methodologies and methods in higher education (see $\mathrm{Fa}^{6}$ avae, 20I8; Iosefo, 20I6). The role of Indigenous Moanan scholars involves disrupting the boundaries within higher education in order to focus on, realise, and re-imagine the significant embodied and emotive spaces that are aligned to our sense of belonging (Pene et al., 2002). Like Ka'ili (2017), I too use the term Moana as a decolonising attempt to re-claim the naming of Polynesia or the Pacific in this chapter. The place of "re" in this chapter is central to the Indigenous Moanan research goal, that is, to seek self-determination and re-conciliation for researchers and their communities (Smith, 1999) by honouring and foregrounding Moana voices and experiences, relational connections, and the sharing of knowledge and practice that enables cultural continuity.

Shawn Wilson (200I), Indigenous scholar and writer of the Cree people from Canada, argued that Indigenous researchers "need to move beyond [just providing] an Indigenous perspective [on western research paradigms] to researching from an Indigenous paradigm" (p. I75). Working-with a particular Indigenous paradigm requires us to thoroughly explore the Indigenous ontology, epistemology, methodology, and axiology that encompass "a set of beliefs about the world and about gaining knowledge that go together to guide your actions as to how you're going to go about doing your research" (Wilson, 200I, p. I75). I fronted a Tongan paradigm in my doctoral research as a deliberate shift from just providing an Indigenous view of why Tongan knowledge and language is de-legitimized in western schooling (see Manu'atu, 2000; Manu'atu et al., 20I0).

\footnotetext{
17 Original people of the land

18 Valued knowledge
} 
Navigating the doctoral writing journey can be perceived as a tool or vehicle for advanced learning within higher education. Doctoral writing is a critical relational space where the inter-connections of ideas and praxis are ongoing and where negotiation is a decolonial potential. When I started my doctoral journey in February 20I4, my first experience of the doctoral writing space was at a workshop organized by the University of Auckland's graduate office. The first year doctoral students who attended were split into groups of three and encouraged to share our intended doctoral projects with each other. The members of my group were excited to share their ideas and desire to use western qualitative and quantitative approaches that have had years of robust application across research disciplines. I was genuinely interested and excited for them. When it was my turn to share my research intentions, however, my proposition to engage in a Tongan research methodology did not elicit a similar response from them.

Koe hā nai ha kaunga 'a e koloa 'a e to'utangata Tonga ki he fekumi moe fakatotolo he mala'e ako? Tatala 'a e koloa 'a e to'utangata Tonga was an outcome of my doctoral project. It is a cultural framework underpinned by intergenerational stories in Tongan kaingā's ${ }^{19}$ sense of being and becoming in an everchanging world. In my doctoral study, to ${ }^{6}$ utangata Tonga as valued knowledge was manifested in three forms: koloa $^{20}$, koloa $^{6} \mathrm{ia}^{2 \mathrm{~T}}$, and fakakoloa. ${ }^{22}$

\section{Koloa'ia As Healing: Realising the Value of "I-My-We-Us-Our"}

Koloa'ia is a state of realisation, knowing that what you have is of real worth and value. My father's eldest brother passed away two years ago. His words of wisdom and care continue to resonate in me and my cousins and echoes a reminder of our fatongia ${ }^{23}$ to our to utangata. $^{24}$

Ko ho'o mou fatongia ke tā ha sipinga lelei ma'ae to'utupu.

19 Extended family

20 The valued knowledges and practices transmitted from generation to generation within the extended family

21 An internalized state within which one realises and acknowledges the significance of the knowledge transmitted

22 The act of purposefully continuing the transmission and sharing of knowledge to the next generation for the collective's continuity

23 Sense of obligation to the collective within Tongan extended families

24 Generations of Tongan people 
... Tokoni'i nautolu ke 'oua tenau hē. [Your obligation is to role model good ways and practices for your brothers and sisters and their children.... Support them so they are not lost.]

We often take for granted what we have until we have either lost it or are close to losing it. The goal to acquire western academic knowledge in high school, advocated by my father, led to mixed feelings in me about the place of our Tongan ancestral knowledge in schooling contexts. However, my realisation over its place in university came when I embarked on my doctoral study. Working-with the intergenerational stories of families in New Zealand and Tonga meant I had an obligation to give back to them, even beyond the project's end. Within the doctoral education space, it provided ways to re-imagine writing, particularly when using Tongan concepts and ideas. In doing so, I found my voice and felt empowered to speak back to western discourses and institutional systems that disadvantaged Pacific peoples.

Doctoral writing shaped my doctoral being and becoming, and it provided healing. The learning processes associated with writing promulgated emancipatory feelings and attitudes that affirmed a place to stand from, seeking self-determination. Not only that, but learning to write and weave together Tongan concepts and methodology with non-Indigenous ideas was to engage in what McDowall \& Ramos (2017) termed epistemic disobedience in higher education. Using Tongan approaches in my doctoral thesis enabled me to re-connect with Tongan "embodied and emotive" expressions and practices (Hook, 20I6, p. 2). Being embedded within this process of writing in the Tongan language and using Tongan ideas such as koloa, koloa'ia, and fakakoloa ignited intimate, spiritual, and sacred feelings often alluded to by Tongans as the emotional state of mālie ${ }^{25}$ and māfana ${ }^{26}$ (Manu'atu, 2000).

'Oku mahu'inga makehe ai hono ngaue'aki 'o e "au-hota-hotau-kitauakitautolu" ' $i$ ha fokotu'utu'u mo fatu talanoa 'i ha fekumi pe fakatotolo? The use of the first person "I-my" when writing is a liberating experience. McDowall \& Ramos (2017) claimed that the use of first person in doctoral writing is important so readers can "recognize it was not a robot that had done the research, but a living breathing person" who made an "original contribution to knowledge" (p. 56). Many Indigenous researchers from collectivist groupings who utilize Indigenous paradigms believe that all knowledge is relational (Mika, 20I7; Wilson, 200I). To them, the role of "I-my-we-us-our" in doctoral

25 The energising and uplifting of spirits to a positive state of connectedness and enlightenment

26 Inwardly warm feelings 
writing is vital to positioning their responsibilities as researchers in universities and as members of Indigenous communities. Doctoral writing has the potential to heal the researcher by mediating the inter-relations between being and becoming an Indigenous researcher in relation to his/her positionality within his/her Indigenous community and in the university community. Similarly, doctoral writing has the potential to honor and privilege Indigenous knowledge and culture, especially for metropolitan Moana academics in New Zealand, Australia, and the US who may not always identify with the heritage languages and cultures of their Moana parents and grandparents.

'Oku 'i ai 'a e ngaahi faka'uhinga loloto 'i he lea faka-Tonga pea 'oku hā ia 'i he fo'i lea ko e to'utangata Tonga. McDowall \& Ramos (20I7) argued that the "language we use to write is not value free" (p. 59). My Tongan values and ideals were inherent in the language and style I used in my doctoral thesis as well as in publications thereafter. The act of re-presenting, re-capturing, and re-telling intergenerational stories through publications and presentations were conditional on my respecting and honoring the và and veitapui with the kāinga involved in the doctoral project. During a writing retreat at the St. Francis Retreat Centre in Royal Oak, New Zealand, I joined a group of master's and doctoral Moana students from the University of Auckland Faculty of Education. When asked by the co-ordinator as to what sessions I wanted to organise for the students, I opted to offer my insights and share knowledge about what it might mean for students to use an Indigenous research methodology and Indigenous theoretical concepts or ideas in their studies. This engagement with my peers was my enactment of fakakoloa and extending the vā and veitapui with my Moana sisters and brothers - a pedagogical engagement I value, one that fulfills my sense of service as an Indigenous researcher seeking to navigate and privilege Indigenous knowledge in higher education.

\section{Fakakoloa and Active Leadership: For- By-With-Pacific People}

'Oku mahu'inga 'a e fakakoloa he ko e taha ia ha 'ulungānga 'oku fotu mei ha tokotaha 'oku taki lelei. To fakakoloa requires active leadership. To fakakoloa is to share and impart stories that will empower and transform Indigenous peoples' lives. As a key principle within the tree of opportunities metaphor, fakakoloa is to enable active leadership. Moana leadership is driven for-Pacific, by-Pacific, and with-Pacific. Despite the growing number of Moana-Pacific-Pasifika students in higher education institutions, there is still a shortage of Moana-Pacific-Pasifika academics (McAllister et al., 2019). Both 
Tara McAllister et al. (2019) and Sereana Naepi (2019) have argued that universities need to make "dramatic structural changes if they are to meet their own and national commitments to Māori and Pasifika communities" (Naepi, 20I9, p. 23I). Moana-Pacific-Pasifika academics and researchers should lead research spaces that involve their communities (Naepi, 20I9), a commitment and responsibility that should be honored, respected, and cared-for within the vā (Iosefo, 20I6).

Moana leadership is a critical component in sustaining Indigenous peoples' aspirations. The idea of "for-Pacific, by-Pacific, and with-Pacific" people is central to the drive for self-determination (Suaalii-Sauni, 2or7; Taufe"ulungaki, 20I4). After 30 years of dis-satisfaction with Pacific education reforms and "significant investments by national governments and donor agencies" (Pene et al., 2002, p. I) in the moana ${ }^{27}$, a group of 19 Moanan scholars gathered together in Suva, Fiji, to "share, debate, and reflect what they believe[d] to be the main issues and challenges in Pacific education" (Pene et al., 2002, p. I). The tree of opportunity metaphor was developed by the leaders as appropriate for re-thinking Pacific education, highlighting the central purpose of Pacific education in the region, which is to ensure the "survival, transformation, and sustainability of Pacific peoples and societies, with its outcomes measured in terms of performance and appropriate behavior in the multiple context [s] in which they have to live" (Pene et al., 2002, p.3). For Indigenous communities, foregrounding and writing using Indigenous ideas, language, and knowledge is significant in any research project that involves them.

'Oku mahu'inga 'aupito ke tau fili ha kakai totonu 'a ia 'oku nau taukei 'i he mala'e 'oku fakahoko ai ho'o fekumi mo ho'o fakatotolo. Central to navigating the doctoral education spaces is having the right combination in your supervision team. Having a Tongan supervisor, Linitā Manu'atu, paired with a non-Indigenous academic, Alison Jones, was critical in my learning to re-connect, re-concile, and navigate doctoral learning and academic writing as a Tongan researcher. Over time, nurturing the vā relationship between my supervisors and me enabled me to see how Tongan language and culture could be capitalized in higher education. Linitā provided the cultural expertise, showing me how to re-imagine and re-frame Bourdieu's (1977) cultural capital from a Tongan lens, whereas Alison shared her expertise of institutional knowledge and academic writing and practices in a way that nurtured my own critical thinking and writing.

I was responsible for supporting students with their research methodologies at a writing retreat for Pasifika postgraduate students held at the Uni-

27 Ocean 
versity of Auckland in December 20I9. Most students deliberately utilized Indigenous research frameworks and methodologies in their projects, which to me suggested an intentional decision not only to research using Indigenous research frameworks but also to theorize and write using Indigenous ideas and concepts. They shared that their sense of connection-with (or disconnection from) their parents' and grandparents' heritage languages and cultures drove their decision-making. It is important to understand that a certain level of vulnerability is exposed when working within an Indigenous research paradigm. While one might want to dig deep into their Indigenous knowledge and thought, one may not feel they have the language or cultural competency to do so, particularly if there are few guides available to support students along the path. I worry that having few Moana-Pacific-Pasifika academics who have the appropriate cultural knowledge and language needed to guide students can result in a kind of defaulting to western research approaches. I write about this and other vulnerabilities and challenges elsewhere (see Fa'avae, 20I9).

\section{Ko e Talanoa ke Hokohoko Atu: Conclusion}

'Ko e vā mo e veitapui ko ha ongo me'a mahu'inga ki he fokotu'utu'u 'o ha fekumi pe ko ha fakatotolo 'oku fekau'aki mo e mahu'inga 'o e ngaahi tala 'a e Tonga 'i he mala'e 'ekatemika. 'Oku mahu'inga 'a e talatalanoa moe talanoa koloa 'o e to'utangata Tonga koe'uhi 'oku hā 'i he vā mo e veitapui 'a e lōloto mo e mataotao ange 'a e 'ilo mo e poto 'a e Tonga. Doctoral being and becoming is an ongoing process of navigation and negotiation. Decolonial potentialities can be re-imagined and their possibilities realized when Indigenous Pacific researchers learn to work-with and apply Indigenous knowledge and concepts, such as và and veitapui, and story their doctoral encounters and experiences through ongoing talatalanoa. Theorising from an Indigenous and decoloniality position and centering Tongan knowledge and concepts empowered my thinking and writing in academia. This chapter not only contributes knowledge to discourse linked to doctoral writing within discursive spaces but also raises the criticality of doctoral writing as a tool for re-claiming self-determination for Indigenous researchers. Working-with the hyphen has enabled me to apply Indigenous knowledge and concepts within a dominant western space. I hope this chapter has demonstrated how vā and veitapui are significant in navigating and honoring the re-presentation, re-telling, and re-interpretation of our stories that underscore fluidity, richness, and nuances in the lived realities of Moana-Pacific-Pasifika peoples' lived realities in the diaspora. 


\section{References}

Aiavā, F. (2017). From in-between to inness: Dehyphenating diasporic theologies from a relational perspective. In U. L. Vaai \& A. Casimira (Eds.), Relational hermeneutics: Decolonising the mindset and the Pacific Itulagi (pp. 121-142). University of the South Pacific; Pacific Theological College.

Amituanai-Toloa, M. (2006). Tapuia (space made sacred) in bridging research and relationships: Brown culture and commonsensical ethics. Alter $\mathrm{Na}$ tive: An International Journal of Indigenous Peoples, 3(1), 201-219. https://doi. org/10.1177/117718010600300111

Bourdieu, P. (1977). Cultural reproduction and social reproduction. In J. Karabel \& A. H. Halsey (Eds.), Power and ideology in education (pp. 487-510). Oxford University Press.

Burford, J. (2016). Uneasy feelings: Queer(y)ing the affective-politics of doctoral education [Doctoral thesis, University of Auckland]. University of Auckland ResearchSpace. http://hdl.handle.net/2292/31268

Burford, J., \& Hook, G. (2019). Curating care-full spaces: Doctoral students negotiating study from home. Higher Education Research E Development, 38(7), 1343-1355. https://doi.org/10.1080/07294360.2019.1657805

Churchward, C. M. (2015). Tongan dictionary: Tonga-English, English-Tongan. King Tupou VI Coronation (Special ed.). Nuku'alofa, Tonga: The Government of Tonga.

Fa'avae, D. (2016). Tatala 'a e koloa 'o e to'utangata Tonga i Aotearoa mo Tonga: The intergenerational educational experiences of Tongan males in New Zealand and Tonga [Doctoral thesis, University of Auckland]. University of Auckland ResearchSpace. http://hdl.handle.net/2292/32183

Fa'avae, D. (2018). Giving voice to the unheard in higher education: Critical autoethnography, Tongan males and educational research. MAI Journal, 7(2), 126-138. https://doi.org/10.20507/MAIJournal.2018.7.2.2

Fa'avae, D. (2019). Tatala 'a e koloa 'o e to'utangata Tonga: A way to disrupt and decolonise doctoral research. MAI Journal, 8(1), 3-15. https://doi.org/10.20507/ MAIJournal.2019.8.1.1

Fa'avae, D., Jones, A., \& Manu'atu, L. (2016). Talanoa'i 'a e talanoa-Talking about talanoa: Some dilemmas of a novice researcher. AlterNative: An International Journal of Indigenous Peoples, 12(2) pp.138-150. https://doi.org/10.20507/ AlterNative.2016.12.2.3

Grant, B. M. (2008). Agonistic struggle: Master-slave dialogues in humanities supervision. Arts and Humanities in Higher Education, 7(1), 9-27. https://doi. org/10.1177/1474022207084880

Hook, G. A. (2016). Geographies of emotion in university spaces: Sole parent postgraduate subjects negotiating 'child-free' educational boundaries. Emotion, Space and Society, 18,1-8. https://doi.org/10.1016/j.emospa.2016.01.004

Iosefo, F. (2016). Who is eye? An autoethnographic view on higher educational spaces from a Pasifika girl. In e. emerald, R. E. Reinhart \& A. Garcia (Eds.), 
$\mathrm{Fa}^{2} \mathrm{avae}$

Global south ethnographies: Minding the senses (pp. 197-208). SensePublishers. https://doi.org/10.1163/9789463004947_017

Ka'ili, T. O. (2017). Marking indigeneity: The Tongan art of sociospatial relations. University of Arizona Press. https://www.jstor.org/stable/j.ctt1t89kr9

Kovach, M. (2015). Emerging from the margins: Indigenous methodologies. In S. Strega, \& L. Brown (Eds.), Research as Resistance: Revisiting critical, indigenous, and anti-oppressive approaches (2nd ed., pp. 43-64). Canadian Scholars' Press; Women's Press.

Mahina, 'O. (2005). The poetics of exile: Love and death in Tongan poetry. Literature E Aesthetics, 15(1), 136-147. https://openjournals.library.sydney.edu.au/index. $\mathrm{php} / \mathrm{LA} /$ article/view/5075/5780

Manathunga, C. (2007). Supervision as mentoring: The role of power and boundary crossing. Studies in Continuing Education, 29(2), 207-221. https://doi. org $/ 10.1080 / 01580370701424650$

Manu'atu, L. (2000). Tuli ke ma'u hono ngaahi mãlie: Pedagogical possibilities for Tongan students in New Zealand secondary schooling [Doctoral thesis, University of Auckland] University of Auckland ResearchSpace. http://hdl.handle. net/2292/715

Manu'atu, L., Fale, L. 'O. 'E. H. L., Finau, M. P., Kaufusi, 'A., Malupo, T. K., Manu, 'A., Pau'uvale, L. D., Pau'uvale, M., Pale, M. F., Prescott, J., Tautakitaki, M. 'I., Tautakitaki, P., Teisina, J., \& Tu'Itahi, S. (2010). Ko e hā ha'atau poa ki he mole 'etau lea faka-Tongá? AlterNative: An International Journal of Indigenous Scholarship, 6(2), 180-186. https://doi.org/10.1177/117718011000600210

Manu'atu, L., Taione, M. 'I., Mabbs, N., Finau, V., \& Fihaki, M. (2016). Uike kätoanga ${ }^{6}{ }^{6}{ }^{6} 0$ e lea faka-Tonga: Tongan language week. New Zealand Ministry for Pacific Peoples; Te Papa. https://www.tepapa.govt.nz/sites/default/files/final_final_version-_tongan_resource_2016.pdf

Martin, B., Stewart, G., Watson, B. K., Silva, O. K., Teisina, J., Matapo, J. \& Mika, C. (2020). Situating decolonization: An Indigenous dilemma. Educational Philosophy and Theory, 52(3), 312-321. https://doi.org/10.1080/00131857.2019.16 52164

McAllister, T. G., Kidman, J. Rowley, O., \& Theodore, R. F. (2019). Why isn't my professor Māori? A snapshot of the academic workforce of New Zealand. MAI Journal, 8(2), 235-249. https://doi.org/10.20507/MAIJournal.2019.8.2.10

McDowall, A., \& Ramos, F. (2017). Doing decoloniality in the writing borderlands of the $\mathrm{PhD}$. The Australian Journal of Indigenous Education, 47(1), 54-63. https:// doi.org/10.1017/jie.2017.23

Mika, C. (2017). Indigenous education and the metaphysics of presence: A worlded philosophy. Routledge. https://doi.org/10.4324/9781315727547

Ministry of Education. (2001). Pasifika Education Plan. New Zealand Ministry of Education.

Naepi, S. (2019). Why isn't my professor Pasifika? A snapshot of the academic workforce in New Zealand universities. MAI Journal, 8(2), 219-234. https://doi. org/10.20507/MAIJournal.2019.8.2.9 
Pene, F., Taufe'ulungaki, A. M, \& Benson, C. (2002). Introduction. In F. Pene, 'A. M. Taufe' ulungaki, \& C. Benson (Eds.), Tree of opportunity: Re-thinking Pacific education (pp. 1-3). Institute of Education; University of the South Pacific.

Samu, T. W. (1998). Social Studies: The nebulous "Cinderella" subject of the New Zealand school curriculum [Unpublished master's thesis]. University of Auckland.

Shipman, M. D. (1971). Education and modernisation. Faber \& Faber.

Smith, L. T. (1999). Decolonizing methodologies: Research and indigenous peoples. University of Otago Press.

Suaalii-Sauni, T. (2017). The Va and Kaupapa Māori. In T. K. Hoskins \& A. Jones (Eds.), Critical conversations in Kaupapa Mãori (pp. 161-178). Huia.

Taufe'ulungaki, 'A. M. (2014). Look back to look forward: A reflective Pacific journey. In M. 'Otunuku, U. Nabobo-Baba \& S. Johansson Fua (Eds.), Of waves, winds and wonderful things: A decade of rethinking Pacific education (pp. 1-15). University of the South Pacific Press.

Taufe'ulungaki, A. M. (2015). Ko e koloa 'a e Tonga. In '. N. Tu'ivakanō, ‘. F. Fusitu'a, '. M. Taufe 'ulungaki, S. Havea \& M. L. 'Ilaiū (Eds.), Tonga: Fonua 'a kāinga (pp. 1-14). United Nations Development Programme.

Thaman, K. H. (1995). Concepts of learning, knowledge and wisdom in Tonga, and their relevance to modern education. Prospects, 25(4), 723-733. https://doi. org/10.1007/BF02334147

Vaioleti, T. M. (2016). Talanoa: A Tongan research methodology and method. In M. A. Peters (Ed.), Encyclopedia of educational philosophy and theory. Springer. https:// doi.org/10.1007/978-981-287-532-7_15-1

Wilson, S. (2001). What is an Indigenous research methodology? Canadian Journal of Native Education, 25(2), 175-179. 



\title{
Writing a Doctoral Thesis in a Non-Western Voice
}

\author{
Sharin Shajahan Naomi \\ Asian University for Women, Bangladesh
}

\begin{abstract}
My Ph.D. thesis on Tibetan Buddhism and feminism uses autoethnographic performative writing to invoke a non-Western voice that challenges colonialities of knowledge production. Studying at the time as an international doctoral student in Australia, I chose to focus my thesis on my experience as a Bangladeshi female writing in an academic context that is predominately influenced by the hegemony of Western knowledge. By waging epistemic disobedience through performative writing, I created a space for writing a doctoral thesis with a non-Western voice. Nonetheless through my journey, I encountered struggles and addressed questions of legitimacy. Despite this, I endured. In this chapter, I aim to unpack my strategies and challenges, offering a fresh perspective on what it is like to be a non-Western doctoral student enacting academic resistance.
\end{abstract}

In autoethnography, researchers analyze their own experiences to address the main themes of their research (Ellis et al., 20II). Autoethnographers work to connect personal experience to wider political and cultural contexts. Many autoethnographers have used these tools to enable the representation of the voices, languages, and narratives of others, especially the marginalized and the subaltern, who do not have the opportunity to speak due to the authority and surveillance of hegemonic power structures within the academy (Holt, 2003; Lincoln \& Denzin, 2003). I am an author who builds on and extends this body of work. In my Ph.D. thesis, I used autoethnographic methods to reflect upon my life journey as a Bangladeshi female negotiating Tibetan Buddhist practice and feminist values in an in-between space of cultures, religion, and identity. I undertook this project due to the lack of autoethnographic voices of women of color with regard to understanding the relationship between Tibetan Buddhism and feminism in women's lives, particularly for women across different cultures and religions who came to know Tibetan Buddhist practice by choice, not by birth or family relationships. In this chapter, I describe what happened when I started to write autoethnographically for my doctoral thesis. I began to 
experience difficulties with speaking and writing as a woman and non-Westerner in the hegemonic space of Western academia. In this chapter, I describe the sense of academic suffocation that eroded the spontaneity of my writing and expression and my feeling that I had to speak in a certain way to present my intimate experience of Tibetan Buddhism and feminism. I will make the argument that the enforcement of these writing conventions on doctoral students is evidence of the coloniality of knowledge production that operates in Western academia (see also Fáavae, Chapter 8, this collection).

\section{The Academic Writer: Post-colonial Approaches}

Across my doctoral experience, I came to appreciate the observations of many post-colonial scholars who have argued that colonialism is not only a system that controls economic and political resources, it is also a system that controls knowledge-making through discourse representation, epistemology and ideology (Mignolo, 2009; Said, 1979; Spivak, 1988). My struggle to write in a Western academic way reminded me of both Gayatri Spivak's (1988) description of the subaltern's struggle to speak as a subject in Western discourse and Trinh T. Minh-ha's (199I) description that the people at the margins within the field of Western knowledge production are women, natives, and the others. Both poststructuralist and postcolonial paradigms critique the limitations around voice and speech, seeing these limitations as rooted in the oppressive structures of particular kinds of discourse. I found in the Western intellectual realm, if one is a woman as well as non-Westerner, her sense of otherness is tripled. She is less privileged than her White Western sisters, less fortunate than White Western men, and less advanced than non-Western men.

My desire to write in a non-Western voice invited three important questions: What might it mean to speak with a non-Western voice in my thesis? Could I do this as an international researcher studying in Australia? And, how could I invoke a non-Western voice without creating further oppositional politics, another boundary of "us" versus "them?" Before considering these questions, I want to unpack how I identify as non-Western in order to more fully understand my resistance as a woman of color in the Western academy and the context within which my voice is embedded. Explaining our location can help to reveal our own subjective views regarding who we are, where we come from, and how our experiences have shaped our identities and the intentions that may lie behind our research (Absolon \&Willet, 2005). Without valuing and acknowledging location in narratives, there is a risk that the dynamic nature of a non-Western voice can be reduced to another category in opposition to a Western voice. 
Since childhood, I have had an ambivalent relationship with the West as well as with my own culture. I was born and brought up in Bangladesh, which, as a part of India, was subject to British colonization for hundreds of years. Its education system and politics are highly influenced by Western liberal ideas as well as by Bengali culture and Islamic religious values. Like many other middle-class families, my family retained the paradoxical lineage of practicing traditional Bengali culture, Islamic values, and Western liberal ideas simultaneously. Western liberal ideas of freedom and human rights were attractive to me as an adolescent. This interest led me to study law. In Bangladesh, our legal system was inherited from our British colonial legacy and is rooted in Western liberal ideas, the Enlightenment approach, and the Western adversarial model of argument. I was trained in this system for years and became an excellent debater on legal issues. Yet when I was in Bangladesh, I felt I never belonged there. My thoughts and approaches to life were very radical and seemed to be incompatible with my surroundings. I thought perhaps I was like a Westerner. However, when I went to Australia for graduate study, I soon learned that I was not a Westerner either.

My graduate research was about Tibetan Buddhism and feminism. My choice of topic was influenced, in part, by my own experiences as a feminist and non-Western woman who lived in-between cultures, countries, and religions. I was not born a Buddhist. Tibetan Buddhism drew my attention later when I was in my mid-2os, having a personal crisis, and looking for meaning in life. I had the opportunity to explore Tibetan Buddhist practice with more depth and contemplation while I was in Australia, accessing Tibetan Buddhist institutions that provided Buddhist teachings mainly to Western students. As a result, my interactions and experiences with this Eastern tradition remain culturally blended, in the space of in-betweenness. Little did I realize that I was inventing a Buddhism, one shaped and reshaped by my situations, positionality, creativity, imagination, freedom of choice, and, more importantly, my in-betweenness. Occupying this in-between space has had a profound impact on shaping my worldview and my writing. Living within this space has encouraged me to negotiate creatively institutions, traditions, and cultures as well as Western and feminist values. Buddhism influenced my feminist worldview and vice versa. They encounter, interact, and co-mingle in such a way that their boundaries became amorphous and indeterminate. Their conversation began to unfold in an in-between space where categories and binaries diffused. I wanted my doctoral thesis to reflect the voice that was arising from that in-between space.

The combination of my spiritual and feminist training led me to value the diversity and universality of the human condition equally. My spiritual 
practice encouraged me to internalize interdependence, the oneness of all creations, and the non-dual and non-hierarchical relationship between individualism and interconnection. Within this context, the differences I raised in my thesis were not about invoking a sense of otherness in binary and oppositional terms. Instead, the difference I invoked was similar to Trinh T. Minhha's (I99I) concept of interdependent multifold feminist gestures-that of affirming "I am like you" without losing sight of how "I am different," all the while unsettling every definition of "otherness" that may be arrived at (p. I52). In my thesis, I invoked a non-Western voice as the voice of difference, a voice and representation of a refusal to represent pure cultural authenticity. I sought to disrupt the dichotomies struck between the East and West. I wanted to unsettle the hegemony of discourses and approaches that claimed to be Western.

This non-Western voice seemed to challenge the coloniality of knowledge in rebellious ways, particularly through practices of epistemic disobedience in writing. This alternative way of writing decolonized knowledge, delving beneath-challenging and deconstructing the subtle structure within the discourse, texts, and meaning through performative narrative (Denzin, 2009; Diversi \& Moreira, 2009). Yet, this chapter is not only about my strategies for claiming a non-Western voice. It is also an account of the price of the epistemic disobedience, the price of claiming that voice that I invoked in writing, and the price of crossing the disciplinary boundaries of feminism, religious studies, arts, and creative writing. The price for choosing an alternative path was high for me, resulting in having a hard time with the orthodox White dominated academic policing, which required a sustained intellectual investment from me in order to overcome such hurdles.

In Western academic realms, doctoral writing needs to show an intellectual allegiance to a particular discipline or theoretical framework, which was hard to notice in my work due to its rebellious nature. It cannot be categorized in a particular discipline like religious or gender studies nor in a particular theory like postmodernism. For some academics, this lack of categorization shown by my writing was the start of a new beginning, but for others it was a sign of disability. The effort and investment needed for finding and using a good number of references to support my argument and writing style and to reduce the risks of my thesis being rejected was an arduous process required of me if I wanted to craft a new path of negotiations and resistance. I felt I was producing a thesis in a space that was in-between multiple disciplines and theoretical approaches and worried my thesis would suffer from this non-belonging. In many ways, my thesis became a strange reflection of my worldviews and life that refused to fall into neat categories, be they categories 
of religion, culture, discipline, or theoretical approaches. At the same time, my thesis offered an invitation to depart from conventional ways of writing theses as well as an opportunity to challenge colonialism and coloniality.

\section{Hegemony of Western Knowledge}

Even though I am critiquing the hegemony of Western knowledge, I think it is important to clarify that I am certainly not in favor of the total abandonment and replacement of Western knowledge, nor is this my aim. Instead, I think it is more important (and interesting) to untangle and reveal the subtle ways the hegemony of Western knowledge replicates itself and retains its power. Western colonial interests, particularly in the realm of knowledge production, are sustained through a pervasive privileging of Eurocentric ideas and representation of others (Mignolo 2009; Said, 1979). As a result, authoritative forces such as gatekeepers are invested in maintaining Western intellectual lineages that have been inherited and passed down. This means, as Obioma Nnaemaka (2003) keenly observed, Western methods of producing knowledge, even postmodern ones, have difficulty accommodating African worldviews. No wonder knowledge from Asia, Africa, and the Global South-all that belongs to subaltern and non-Western locations-becomes either muted, suppressed, or devalued when viewed from a Western perspective. Similarly, one reviewer of my thesis used these unwritten rules and practices (and even the threat of certain repercussions) to criticize the style and approach I took in it. In my thesis, I explored the ways imperialism works to prioritize one form of knowledge and position it as superior in relationship to others (Battiste, 1998). This imperialism has been seen as the dominance of knowledge from the Global North over knowledge from the Global South (Trahar et al., 20I9). In this intellectual imperialism, the legitimacy and acceptability of knowledge are evaluated according to standards determined by a predominately Anglophone center. For instance, the ranking of a journal often hinges on the inclusion of scholarly references originating from the Global North (Trahar et al., 2019). Often this knowledge from the Global North is considered to be "the standard," and knowledge from the non-Western world remains seen as inferior, supplementary, and peripheral.

I found this hegemony is nurtured and sustained by some invisible rules. For instance, it seems that one's scholarly insights are judged on the basis of their connection to Eurocentric ideas and Western scholars and that one's expressions are considered to be more accurate if they follow conventional and positivist rules of linearity, categorization, separation, and syllogism-inherited from classical Greek and Roman philosophic approaches. The influence 
of Aristotelian logic, as Kaiping Peng and Richard Nisbett (1999) explained, is dominant in Western discourse and tends to prioritize a single claim, linear solutions, consistency, counter argumentation, and the negation of oppositional arguments. Aristotelian logic relies on forms of deductive reasoning. One example of this reasoning is the following syllogism:

All men are mortal

Socrates is a man

Therefore, Socrates is mortal.

In the Western intellectual tradition, Aristotelian logic plays a significant role in validating arguments. The importance this type of reasoning has for furthering the evolution of disciplines such as science and law is immense. However, the overreliance on this type of reasoning as the only (valid) form of reasoning often results in less space allocated to other forms of reasoning and argument. Eastern intellectual traditions, such as the Chinese dialectic style, are based on an appreciation of reality as holistic, fluid, dynamic, flexible, and full of contradictions. Within this style, answers are not couched in either/ or terms. Instead, two contradictory positions can co-exist in harmony and mutual connection. Similarly, Indian philosophical thought aims to transcend any dualistic positions and claims. Klaus Klostermaier (2007) noted that unlike many Western philosophies, meditative reasoning in Indian philosophical thought (Buddhist and Hindu) creates space for dispute and dialogue, which do not move with logic alone. Scott Stroud (2002, 2004) has written about a particular style of argument found in Indian Vedic texts that follows an argumentative style different from that used in dominant Western argumentative discourses. In the Indian multivalent style, the point of the argument is not for a propositional claim to be accepted or rejected. Instead, the argument and textual strategy lead the mind of the reader to an experience that goes beyond oneself and reality. Stroud (2002, 2004) gives the example of Devi Gita, a sacred Hindu text about the Great Goddess where the Goddess is seen as both separate from the world and immanent and present in everyone and everything. These contradictory aspects are narrated in such a playful way that readers cannot reject a single claim and adopt another. Stroud thinks that (2002, 2004) when Western audiences read this narrative, they tend to either reject this contradiction as absurd and nonsensical or ponder the meaning in a new way. To find meaning, readers need to go beyond a search for the legitimacy of a single claim (e.g., whether a God or Goddess is separate or immanent in the world). As a result, readers experience the multiple possibilities that present themselves when they go beyond categorical borders of binary 
judgments. Readers have to engage the contemplative facilities of their minds to uncover new wisdom, similar to the thinking process they might use to connect with poetry, music, and art. They need to experience a fusion, merging the nonverbal and nonconceptual with the analytical tendencies of the mind, to get to meaning. They need to contemplate how contradictions can come together and unfold a wider and deeper meaning that might not otherwise be comprehensible through a single claim or a straightforward reading.

When I started to write an autoethnographic thesis, my argument unfolded under the influence of these Eastern ways rather than the classical logic of mainstream Western discourse. A monologic discourse based on an essential, binary, conclusive, and reductionist view would overlook the intention behind my writing. It would miss the invitation to explore non-dual relationships that exist between the categories and fluidity of life and that value multiple creative possibilities for harmony across multiple positions and representations. When my thesis is read with a simultaneous focus on the multiple voices I tried to represent, it offers-I think —an engaging way of producing knowledge (Henderson, 20I4). That's what was missed by the evaluators of my thesis. My Ph.D. thesis was about my life, full of intimate spiritual experiences, identity, and culture. I did not find Western ways of argument and linear and objective ways of writing suitable to my voice or aims, so I did not rely on them. I found my voice suppressed. I could not be spontaneous. My thesis was accused of "lacking rigor," and my writing labeled "not so clear." It became quickly apparent that following a non-adversarial way of argument and logic was annoying to a positivist mindset that still dominates academia.

\section{My Strategies to Invoke a Non-Western Voice in My Thesis}

I was lucky that my supervisor was aware of my struggle with this in-between space I have described. Seeing my efforts to channel my voice while, at the same time, attempting to please the dominant academic demands, my supervisor suggested that I take up different strategies for writing my thesis. One of these strategies included seeing the thesis as embodied writing-seeing it, in other words, as a part of my being. Here, autoethnography was extremely helpful, as it enabled me (as a doctoral writer) to enter a space where I could speak from multiplicity, heterogeneity, plurality, and indeterminacy of meaning-seeing all as a part of the research itself (Bordo, I990; Tsalach, 2013). But autoethnography was not enough to challenge the ways the hegemony of Western knowledge practices prevail in academia, suffocating spontaneity and voices from non-Western worlds. While writing my autoethnography, I needed to adopt epistemic disobedience in order to resist predominately $\mathrm{Eu}-$ 
rocentric epistemologies that prioritize hierarchy, objectification, structure, and positivist modes of clarity (Conquergood, 2002; Mignolo, 2009; Smith, 1999). But adopting epistemic disobedience is extremely risky, especially for a doctoral student who is neither a prominent academic nor a Westerner. I became interested in post-colonial writers such as Gayatri Spivak and Homi Bhaba, but I still found their epistemology and writing to be quite Western. Eventually, I found that Trinh T. Minh-ha (1989, 199I) and Shawn Wilson (2008) did more to challenge Western positivist ways of knowing and writing. I was aware that I was at risk of being alienated, but I decided to go for it anyway. In doing so, I paved a new path for myself, one that allowed me to write with a non-Western voice and to release the psychic effects of colonization at the same time. In this process of engaging in epistemic disobedience, I also discovered the usefulness of performative writing - another strategy that might be useful for doctoral writers

Performative ways of writing value creative engagement through recognizing human complexity and its relation to ideas. Since the I96os, performative writing has been used in the humanities and other disciplines to create interactive critical insights and to bring alive ways of knowing, writing, and interpretation that would otherwise be hidden in conventional writing and its attempts at objectivity (Allsopp, I999; Espi, 2013). According to Ronald Pelias (20I4), there is a difference between conventional writing and performative writing. Conventional writing is aimed at advancing knowledge through argument and intellectual analysis. Although performative writing also addresses intellectual questions, it seeks an answer to intellectual questions through the process of connecting human emotion and intellect to scholarly ideas. Using performative writing techniques took my autoethnography and made it into an artistic tool for expression, one that invoked compassion and empathy via the relating of personal experiences (Custer, 20I4; Ellis, 1999). As part of this process, the biographical narratives in my thesis were accompanied by personal photographs and art. The images responded to my research quest for "felt, touched and embodied constitutions of knowledge" through an intimate connection with the past (Scarles, 20I0, p. 50I; Noy, 2008). More importantly, the images had performative and strategic value in that they unsettled the text-centric culture of Western scholarly writing.

Said (I979) explained "that it is a fallacy to assume that the swarming, unpredictable, and problematic mess in which the lives of human beings live can be understood on the basis of what books-texts-say" (p. 93). Collapsing the dichotomy and categorization in texts and discourse is a part of the scholarly politics of challenging colonial authority (Denzin, 2003). When the politics transgress text-centric Western epistemologies, disciplinary boundaries, and 
fixed meanings, they assume a performative nature through creative-critical pedagogical articulation (Conquergood, 2002). In terms of my biographical narrative, I was interested not only in the contents of the story but also in the way stories are told. For that, I drew on Indian and Zen approaches to narratives. Western thought has tended to follow logocentric logic since Plato (Heine, 1995; Mcquillan, 200I). Unlike Western English narrative's pursuance of a steady plot, Indian narrative allows for deliberate digressions that open up opportunities for performativity and multiplicity (Alexandru, 20I5). A Western perspective might argue that this style lacks coherence and includes unnecessary talk. However, unexplained digressions are integral to the storyline. Similarly, in discussing Zen literature, Margaret Syverson (20II) noted that this type of narrative is full of deliberate and "unexplained contradictions" (p. 283). These contradictions are intended to unsettle and break up the pattern-oriented mind.

The following excerpt from my thesis might provide more of a sense of its rebellious nature in challenging the coloniality of knowledge. This excerpt is about my experience with growing up in space in-between cultures, identities, and worldviews. The main aim of this excerpt is to challenge binary and dualistic ways one might evaluate my non-Western positionality.

When she reached puberty, she was told to give up Western dress and wear the traditional attire. This dress is called Selwar Kameez-long trousers, a long body shirt and a long scarf to cover the breasts. All adult and adolescent women around her were wearing it! She protested vigorously pointing to the discrimination: 'men should also wear the traditional dresses of Bangladesh all the time! Why are they allowed to wear Western clothes (shirts and pants)?'...

She was born and brought up in a simple middle-class family in Bangladesh. Their religion is Islam and the culture is Bengali. This "not so easy combination" is rooted in a complicated history of Bangladesh. Once upon a time, Bangladesh was "the Bengal", part of greater India. Historical Bengal has always been a melting pot of different races. A historian friend said that her facial features indicated that some of her ancestors might be Mongolian. This is very much possible due to an untraceable mingling of different races throughout the history in Bengal!

Bengal was the place where Hinduism and Buddhism ruled for many years. These aspects are still ingrained in the festivals 
and literature of Bangladesh. It was the land where Tantra (both Hindu and Buddhist tantra) flourished and feminine aspects of the divine were worshiped. When Islam arrived in this land from the Middle East, it was integrated into Bengali culture. Their co-existence had tensions as well as mutual understanding and harmonious blending. With the arrival of British colonial power, Bengal became the center of the union between Indian and British thoughts in India. One of the examples of this meeting of cultures was the European influence on Bengali literature. Bengali literature was full of passionate devotion to the divine. European ideas and literature influenced Bengali literature to move towards human's relation with each other (Bhattacharya \& Renganathan, 2015; Islam, 20I4). During the British period, prominent Bengali writers like Rabindranath Tagore merged the divine and human world in a unique way. The merging created multiplicity and non-duality in the meaning of human desire and relation to the mundane world and the divine. Non-duality does not mean that no difference exists between creator and creations. Rather non-duality is an ambivalent play of difference and sameness, one and many in a non-binary way. Non-duality is the possibility of plurality, at the same time it exists beyond this. Even in contemporary times, politics, human relations, mysticism and God all are enmeshed in Bengali literature without any clear line of demarcation. From a Western perspective, this is so obscure! She was brought up reading Bengali literature and unconsciously interpreted the reality from this obscure perspective....

Her family carried the historical lineage of Bengal-a tension, mutual understanding as well as amalgamation among Islam, Bengali culture and Western liberal ideas. It was a third space. Within this third space, she built up her own third space. Her imagination was full of characters from Western fairy tales and she loved Western clothing, values and Western lifestyles. At the same time, she was drawn to Hindu Gods and Goddesses, history and culture of India, and Bengali literature. (Naomi, 20I7, pp. 257-259)

In this narrative, embedded in a Bangladeshi context, I presented apparently contradictory feelings about my location. I created this contradiction 
deliberately to challenge a Western dualistic approach to understanding identity and its tendency to arrive at a singular conclusion. Here, connecting readers to the ideas in such a way that they can "participate in an interpersonal contact of recognizing oneself in all human complexity," my strategy became like Frederick Douglass' (I969) participatory understanding of the politics of performance of resistance for voice and agency, where one can place oneself in the space of the other (Conquergood, I998, p. 28; Pelias, 20I4, p. 16). The performative aspect of narrative in this autoethnographic part of my thesis invoked a "whole realm of complex, finely nuanced meaning that is embodied, tacit, intoned, gestured, improvised, co-experienced, covert and all the more deeply meaningful because of its refusal to be spelled out" (Conquergood, 2002, p. I46).

By purposely writing narrative in an "obscure" way, I agree with Emma Pérez (1999) that one needs to disidentify with the normative gaze to give space to the voices in the margins. There is ambiguity, uncertainty, and unknowing. According to Édouard Glissant (1997), writing this way is an opacity that demands freedom from the violence of absolute comprehension, control, and transparency (see also Lindner \& Stetson, 2009). You need to perceive reality unfolding in multiple, undefinable ways. If reality is summed up in the name of clarity and delineation, its dynamic and transformative nature is renounced.

\section{The Price of Epistemic Disobedience}

Primarily, I wanted to write my thesis to contribute to research on Tibetan Buddhism and feminism. But my epistemic disobedience took my thesis away from these disciplines. I started to realize this was happening while giving presentations in various academic workshops and seeing the academic backgrounds of the audience. My thesis began to resonate more with audiences who were interested in creative writing and less with audiences hoping to hear about religious studies.

The initial years of my Ph.D. studies were full of both appreciation and critique for my writing style, especially for my use of performative, non-Western narrative. I was fortunate enough to have a very understanding supervisor. The suggested improvements or modifications my supervisor made were never meant to alter my style; they were intended to make my ideas more meaningful, expressive, and engaging. However, not every audience in every academic or intellectual platform where I gave presentations was understanding or empathetic about my struggle to promote non-Western voice. I found their academic approaches very structurally embedded in the habitual 
tendency to judge an intellectual project from objective lenses, which I see as having the capacity to promote the mutilation of a researcher's subjectivity, location, and context from academic writing. In response to their harsh criticism and silent withdrawals in workshops or conferences, I had to reshape my argument with the support of post-colonial arguments and the decolonization of knowledge to save the creative impulse of the thesis and to make space where a non-Western woman, a subaltern, could speak. More and more pages were allocated to arguing for a non-Western voice, with plenty of references. This struggle for justifying a space for a non-Western voice also continued throughout the examination process of the thesis.

\section{Conclusion}

In a hegemonic system of knowledge production, a creative tension is created when subaltern, marginalized, or different voices speak. There can be shock, wonder, confusion, and a break of presumptions and expectations. Alison Jones (I999) wrote about the disappointment of dominant groups at the resistance of subalterns as shown through their speaking and at the loss of previous patterns of their authority. Jones (1999) considered this disappointment to be positive for including non-Western knowledge and worldviews, no matter how alien they may seem. This positive disappointment paves the way for broader knowledge and a celebration of the diversity of thinking in human consciousness. Against the backdrop of myriad academic challenges, including the fears of being rejected, sidelined, and not referenced in other works, my doctoral writing symbolizes both a creative tension and a positive disappointment in terms of possibilities and critical dialogue for non-Western voices in doctoral writing. This chapter shows that the presence of non-Western voices in doctoral writing is possible with the help of both White and non-White allies.

There is significant potential for non-Western voices to offer new perspectives and to transform doctoral writing into a democratic platform with diverse voices. One way this diversity can be cherished is by valuing the non-Western epistemologies, narratives, and reflexivities of doctoral students who are going through challenging experiences that might include constraints around spontaneity of voice and fluidity of locations. The work of doctoral students who have chosen to give life to their voices and locations in writing rather than following objective and obedient paths of conventional academia should be supported and seen as a positive example or as a sign of inclusivity. By accommodating and critically appreciating such writing, we could challenge the hegemony of Western methods of knowledge production and explore a wider range of heterogeneous perspectives. 


\section{References}

Absolon, K., \& Willett, C. (2005). Putting ourselves forward: Location in aboriginal research. In L. Brown \& S. Strega (Eds.), Research as resistance: Critical, Indigenous and anti-oppressive approaches (pp. 97-125). Canadian Scholars' Press.

Alexandru, M.-S. D. (2015). Performance and performativity in contemporary Indian fiction in English. Brill.

Allsopp, R. (1999). Performance writing. PAJ: A Journal of Performance and Art, 21(1), 76-80. https://doi.org/10.2307/3245984

Battiste, M. (1998). Enabling the autumn seed: Toward a decolonized approach to Aboriginal knowledge, language, and education. Canadian Journal of Native Education, 22(1), 16-27.

Bordo, S. (1990). Feminism, postmodernism, and gender-scepticism. In. L. J. Nicholson. (Ed.), Feminism/Postmodernism (pp. 133-156). Routledge.

Conquergood, D. (1998). Beyond the text: Toward a performative cultural politics. In S. Dailey (Ed.), The future of performance studies: Vision and revisions (pp. 2536). National Communication Association.

Conquergood, D. (2002). Performance studies: Interventions and radical research. The Drama Review, 46(2), 145-156. https://doi.org/10.1162/105420402320980550

Custer, D. (2014). Autoethnography as a transformative research method. The Qualitative Report, 19(37), 1-13. https://doi.org/10.46743/2160-3715/2014.1011

Denzin, N. K. (2003). Performance ethnography: Critical pedagogy and the politics of culture. SAGE Publications.

Denzin, N. K. (2009). Qualitative inquiry under fire: Toward a new paradigm dialogue. Routledge. https://doi.org/10.4324/9781315421292

Diversi, M., \& Moreira, C. (2009). Betweener talk: Decolonizing knowledge production, pedagogy, and praxis. Routledge. https://doi.org/10.4324/9781315433059

Douglass, F. (1969). My bondage and my freedom. Dover Publications.

Ellis, C. (1999). Heartful autoethnography. Qualitative Health Research, 9(5), 669683. https://doi.org/10.1177/104973299129122153

Ellis, C., Adams, T. E., \& Bochner, A. P. (2011). Autoethnography: An overview. Forum Qualitative Sozialforschung/Forum: Qualitative Social Research, 12(1), Article 10. https://doi.org/10.17169/fqs-12.1.1589

Espi, S. R. (2013). Writing dyslexia. Image and Narrative, 14 (4), 45-56. http://www. imageandnarrative.be/index.php/imagenarrative/article/view/406

Glissant, É. (1997). Poetics of relation (B. Wing, Trans.). University of Michigan Press. https://doi.org/10.3998/mpub.10257

Heine, S. (1995). [Review of the book Mind as mirror and the mirroring of mind: Buddhist reflections on Western phenomenology, by S. W. Laycock]. Journal of Chinese Philosophy, 22(4), 507-510. https://doi.org/10.1111/j.1540-6253.1995. tb00720.x

Henderson, M. G. (2014). Speaking in tongues and dancing diaspora: Black women writing and performing. Oxford University Press. https://doi.org/10.1093/acprof:oso/9780195116595.001.0001 
Holt, N. L. (2003). Representation, legitimation, and autoethnography: An autoethnographic writing story. International Journal of Qualitative Methods, 2(1), 18-28. https://doi.org/10.1177/160940690300200102

Jones, A. (1999). The limits of cross-cultural dialogue: Pedagogy, desire, and absolution in the classroom. Educational Theory, 49(3), 299-316. https://doi.org/10.1111/ j.1741-5446.1999.00299.x

Klostermaier, K. K. (2007). Hinduism :A Beginner's Guide. One World Publications. Lincoln, Y. S., \& Denzin, N. K. (Eds.). (2003). Turning points in qualitative research: Tying knots in a handkerchief. AltaMira Press.

Lindner, K., \& Stetson, G. (2009). For Opacity: Nature, difference and Indigeneity in Amazonia. TOPIA: Canadian Journal of Cultural Studies, 21, 41-62. https://doi. org/10.3138/topia.21.41

McQuillan, M. (2001). Introduction: Five Strategies for Deconstruction. In McQuillan, M. (Eds.). Deconstruction: A Reader. NY: Routlage. pp. 1-43

Mignolo, W. D. (2009). Epistemic disobedience, independent thought and de-colonial freedom. Theory, Culture E Society, 26(7-8), 159-181. https://doi. org/10.1177/0263276409349275

Minh-ha, T. T. (1989). Woman, native, other: Writing postcoloniality and feminism. Indiana University Press.

Minh-ha, T. T. (1991). When the moon waxes red: Representation, gender and cultural politics. Routledge. https://doi.org/10.4324/9780203700624

Naomi, S. S. (2017) Tibetan buddhism and feminism in an in-between space: A creative-critical autoethnography in a non-Western woman's voice [Ph.D. thesis, Murdoch University]. Murdoch University Research Repository. https://researchrepository.murdoch.edu.au/id/eprint/40739/

Nnaemeka, O. (2003). Nego-Feminism: Theorizing, Practicing, and Pruning Africa's Way. Signs 29 (2), Development Cultures: New Environments, New Realities, New Strategies. Special Issue Editors Françoise.

Noy, C. (2008). PAGES AS STAGES: A performance approach to visitor books. Annals of Tourism Research, 35(2), 509-528. https://doi.org/10.1016/j.annals.2008.02.005

Pelias, R. J. (2014). Performance: An alphabet of performative writing. Routledge. https://doi.org/10.4324/9781315422770

Peng, K., \& Nisbett, R. E. (1999). Culture, dialectics, and reasoning about contradiction. American Psychologist, 54(9), 741-754. https://doi.org/10.1037/0003066X.54.9.741

Pérez, E. (1999). The decolonial imaginary: Writing Chicanas into history. Indiana University Press.

Said, E. (1979). Orientalism. Vintage.

Scarles, C. (2010). Where words fail, visuals ignite: Opportunities for visual autoethnography in tourism research. Annals of Tourism Research, 37(4), 905-926. https://doi.org/10.1016/j.annals.2010.02.001

Smith, L. T. (1999). Decolonizing methodologies: Research and indigenous peoples. Zed Books. 
Spivak, G. C. (1988). Can the subaltern speak? In C. Nelson and L. Grossberg (Eds.), Marxism and the interpretation of culture (pp. 271-313). University of Illinois Press.

Stroud, S. R. (2002). Multivalent narratives: Extending the narrative paradigm with insights from ancient Indian philosophical texts. Western Journal of Communication, 66(3), 369-393. https://doi.org/10.1080/10570310209374742

Stroud, S. R. (2004). Narrative as argument in Indian philosophy: The Astāvakra Gìtā as multivalent narrative. Philosophy and Rhetoric, 37(1), 42-71. https://doi. org/10.1353/par.2004.0011

Syverson, M. (2011). True beginner's mind: Fresh encounters with Zen. Appamada.

Trahar, S., Juntrasook, A., Burford, J., von Kotze, A., \& Wildemeersch, D. (2019). Hovering on the periphery? 'Decolonising' writing for academic journals. Compare: A Journal of Comparative and International Education, 49(1), 149-167. https://doi.org/10.1080/03057925.2018.1545817

Tsalach, C. (2013). Between silence and speech: Autoethnography as an otherness-resisting practice. Qualitative Inquiry, 19(2), 71- 80. https://doi. org $/ 10.1177 / 1077800412462986$

Wilson, S. (2008). Research is ceremony: Indigenous research methods. Fernwood Publishing. 



\title{
10 Decentring the Author/ Celebrating the Typist in Doctoral Thesis Acknowledgements
}

\author{
Frances Kelly \\ Auckland University \\ Catherine Manathunga \\ University of the Sunshine Coast \\ Machi Sato \\ Kyoto University
}

\begin{abstract}
This chapter arises from a project that aimed to trace the presentation of an emerging academic self in thesis acknowledgements across New Zealand, Australia, and Japan. Here, we consider ways that acknowledgements, those marginal sections of the thesis text, decenter the individual author as sole producer of knowledge (Burke, 20I2) and highlight the situated-ness of writing practices, thereby providing alternative imaginaries for doctoral writing. Unlike the main body of the thesis, which must present a legitimate academic authorial self, this peripheral element tends to be a back stage moment (Eik-Nes, 2008) that reveals affective dimensions and the everyday practices of writing and that recognises the involvement of others (people and things) in the research and writing process. Analysis of these texts-within-the-thesis-text enables a reading against the grain — giving insight into who/what else contributes to a thesis and revealing the entanglements of academic scholarship and writing (Barad, 2007).
\end{abstract}

A dominant imaginary of the thesis writer is the solitary author-despite late 2oth century assertions of its demise (Barthes, 1977). At the heart of this imaginary is the western European idea of a transcendental ego removed from social or physical connection (Kristeva, 1973). Yet there are myriad others besides the author who are also involved in producing the thesis, as a reading of doctoral thesis acknowledgements underscores; these texts tell quite a different story about the process of writing a thesis, opening up possibilities for re-imagining 
doctoral writing. The data this chapter draws on are from a project that explored elements of identity formation within doctoral education by tracing the presentation of an emerging academic self in thesis acknowledgements across New Zealand, Australia, and Japan (Kelly et al., 20I7). Here, we analyze historical texts: a corpus of acknowledgements from 1980 from the University of Auckland, University of Melbourne, and Keio University. This was a period in global higher education history on the verge of change as governments began to introduce higher education policies informed by neoliberal agendas, universities grew student numbers, technological developments reframed scholarly practices (Kelly \& Manathunga, 2020), and the idea of global higher education began to shift and intensify by the decade's end as more students traveled to study internationally (Chou et al., 2016).

The three sites' differing historical contexts, however, differently inflected the changing forces that shaped doctoral education in this era. At the University of Auckland (a state university established in I883), Ph.D.s in 1980 were mainly undertaken by those intending on an academic or research career, although a Ph.D. was not a requirement for one in all disciplines and was often done elsewhere. The number of doctoral theses submitted in 1980 was a mere 30 (compared to over 300 in 20I6), completed across the range of disciplines but with the greatest proportion from the sciences (geology, botany, zoology, and chemistry). Similarly, for the University of Melbourne (a state university established in 1853), there were 67 doctoral theses submitted in 1980. We chose to ensure that the thesis acknowledgements of women and scholars in the humanities and social sciences were well-represented in this sample so that we could trace possible gendered or disciplinary patterns. While many of the graduates may have been hoping for an academic career, our analysis indicates that many of these theses were in fields closely related to, and often funded by, industry or public sector research organisations outside the university system (like the CSIRO - Commonwealth Scientific and Industrial Research Organisation). In both Australia and New Zealand, writing a thesis and becoming "an author" was integral to becoming an academic and scholar and, sometimes, an industrial researcher. For Keio University ${ }^{1}$ (a private university established in 1890 ), there were Io9 doctoral theses submitted in 1980; out of those, 63 were for an MD so were excluded, ${ }^{2} 36$ were in engineering,

1 The balance of public to private universities is one of the main differences between Japan and Australia and New Zealand. Chou et al. (2016) estimate that currently around 70 percent of university students in Japan attend private institutions.

2 The MD functions as a "professional qualification" and is different from other academic doctorate degrees (Hashimoto, 1998). 
and to were in other disciplines (literature, law, economics, and commercial science). The Japanese case only focuses on acknowledgements in theses for an engineering doctorate as none of those in humanities and social science disciplines contained acknowledgements in the available copy. This variation indicates different practices of acknowledging others who contributed to the work in a public forum like the published manuscript not only across disciplines but also between Australia, New Zealand, and Japan. Today, it is not mandatory in Japan to include acknowledgements when submitting a doctoral thesis, although practice still varies among the disciplines; it is encouraged in New Zealand and Australian universities where it is mandatory to acknowledge sources of funding and assistance with writing.

We initially approached the acknowledgements with the aim of noticing the writers' social, epistemological, and spatial connections (Kelly et al, 20I7; Kelly \& Manathunga, 2020). Our method was close textual analysis and included paying attention to conventions of the acknowledgements genre (Hyland, 20II) and to extratextual elements including layout and font (McGann, 1992). One effect of reading acknowledgements this way is that the impression of an impermeable thesis diminishes, revealing something that is instead made, the work of hands (Arendt, 1958). Acknowledgements reveal backstage aspects of thesis-writing (Eik-Nes, 2008), creating textual porousness (Barnacle \& Dall'Alba, 20I4) in the single-author text and enabling a different and situated idea of the thesis and writer to emerge. If we use that metaphor of a thesis-text as woven, the acknowledgements are a loophole in the texture showing elements of its making.

Our approach is also informed by an understanding from postmodern theory of the thesis as text that is produced in material and social contexts (Barthes, 1977; Kristeva, 1973). In their discussion of doctoral writing and publishing strategies, Pat Thomson and Barbara Kamler (2013), drawing on Norman Fairclough (1992), suggested that a thesis text is never constructed in isolation from its context. Instead, they argued, a thesis sits within a discourse community that has "specific practices, histories, conventions and expectations," which other members, including supervisors, support the thesis writer to understand, enabling access to the community (Thomson \& Kamler, 20I3, p. 3I). Acknowledgements, we found, reveal people and practices that assist writers in conforming to discourse community expectations and that enable writers to produce texts appropriate to the discursive context. Acknowledgements also indicate the broader forces that shape (enable and constrain) textual production within the academic community and beyond in the wider social, economic, and technological domain (see Molinari, Chapter 2, this collection). 


\section{Writing, Acknowledgements, and the Single Author Idea(l)}

The link between "scholar" and "author" has a long history in university traditions, as others also explore in this volume (see Mitchell, Chapter I). While early European monastic universities engaged in communal scholarly and writing practices (Thomson \& Kamler, 20I3), from the late I8th century advanced students were re-imagined as authors of written texts, such as the doctoral dissertation (Clark, 2006). A doctoral thesis is one of many elements from western models of academia that have been widely, albeit strategically, adapted, resulting in what Meng-Hsuan Chou et al. (20I6) termed an "isomorphism" (p. 3) of higher education institutions globally. The research university "emerged in Germany in the nineteenth century" and was "later adapted in Japan, the United Kingdom and the United States" (Chou et al., 20I6, p. 4). The modern research university was defined by writing rather than speaking, so the idea of the book-fixed, unchanging, able to be distributed-contributed to creating a powerful "authorial persona" (Clark, 2006, p. 2II). Such power and authority necessitated clarity around authorship and raised questions about the nature of collaboration-particularly between supervisor and student. "Where does advice or correction end, and collaboration or co-authorship begin?" asked William Clark (2006, p. 207). With so much at stake (one had to write to get ahead in the Enlightenment), authorship came to be defined as singular, the work of an individual "modern hero of knowledge," so academic writing practices adjusted in conjunction with this ideal (Clark, 2006, pp. 2II-2I2).

The practice of acknowledgement arises out of this history and allows for recognising the input of others without surrendering claims to legitimacy as an author. To put it another way, if other contributors could no longer share a title page, space had to be made somewhere in the text to acknowledge input-financial, intellectual, or otherwise. At the same time, this practice also allowed for the display of one's connections or patrons (Genette, 1997) and membership in a community of scholars (Clark, 2006). Acknowledgements enabled doctoral writers to display social standing and intellectual connections without surrendering claims to authorship.

The conception of the authorial "hero" remained largely unchallenged in western literary and scholarly arenas until the mid- to late-2oth century, when postmodern theorists, including Roland Barthes (1977) and Julia Kristeva (1973), contributed to a questioning (or death) of the idea of the author. According to Barthes (1977), writing is where identity is lost not formed, the role of readers is crucial in the production of meaning, and all texts are the work of many: "Writing is that neutral, composite, oblique space where our subject slips away, the negative where all identity is lost ..." (p. I42); furthermore, 
We know now that a text is not a line of words releasing a single 'theological' meaning (the 'message' of the Author-God) but a multi-dimensional space in which a variety of writings, none of them original, blend and clash. The text is a tissue of quotations....(p. I46)

Despite such assertions, by the I980s, the ideal of single authorship remained (and continues to remain) important in academia because of those same issues of qualification, expertise, and legitimacy that underpin the original concept of the Ph.D. (Clark, 2006). The single-author Ph.D. thesis continues not only as a strongly held imaginary (Kelly, 20I7) but also as a legal credential to practice as a scholar, to be a doctor of philosophy. This was the point made by Jacques Derrida (2004) in his own doctoral defense in 1980: There are "procedures of legitimation" with the conferment of titles that reflect the "essential tie" between the university and "the ontological and logocentric ... system" (p. I2I). In writing, we construct a singular authorial scholarly identity and we justify our right to be conferred with a title. As Robyn Barnacle and Gloria Dall'Alba (2014) put it, "what is the doctoral thesis if not the site in which an author establishes credibility as just that: an authoritative author?" (p. II40).

If acknowledgements began as a textual practice enabling the display of the connections of a scholarly "man among men" (Genette, 1997) without surrendering claims to authorship, scholarly legitimacy, and the title of Dr., they can, however, also reveal the many hands that go into thesis work. What is clear from the acknowledgements we analyzed is that the work of writing is, like research, supported by others. While in our data there was evidence of some credentialising or display of social and scholarly connections, there was also a grounding of the work in everyday sites; recognition of the importance of nurturing relationships; and value placed in the input of others, including providers of beds, makers of tea, and typists.

\section{So Long, and Thanks for All the Typing}

In early conversations about the data, we noticed frequent reference to typists among the acknowledgements from the Univeristy of Auckland (UA) and the University of Melbourne (UM); however, there was no mention of these contributors in the data from Keio University $(\mathrm{KU}) .{ }^{3}$ While there are a range of possible reasons for this, including the fact that several of the Japanese

3 We have used a simple code of the first letter (or first few letters) of the surname of the author plus identifier of the university for quotations from the data. 
theses were hand-written in 1980, we conjecture that, in this context, it may not have been appropriate to include non-academics or non-researchers in an acknowledgement in a published research work-for example, none of the Keio acknowledgements mentioned family members and friends, although these were evident in theses from Australia and New Zealand. Although typists are no longer commonly engaged, they typify the kind of contributor to a thesis who is invisible in (or expunged from) the main body of the text but who appears in acknowledgements, much like present-day third-party editors or proofreaders. Like these typists, editors, and proofreaders, "The Secretaries" acknowledged by one thesis writer (B, UA) in his geology doctoral thesis possessed skill and expertise essential in the thesis' final production, enabling it to conform to the conventions of the academic discourse community (Fairclough, 1992; Thomson \& Kamler, 2013), to meet requisite university standards, and to be a text appropriate for the context.

A corpus of acknowledgements from one particular time and place, the University of Auckland in 1980, created an impression of typists as skilled and knowledgeable discourse community brokers for doctoral writers-similar to the role that Thomson and Kamler (2013) ascribed to peer reviewers. In the New Zealand data, there were several examples of different authors in one discipline thanking the same typist. For example, three from chemistry acknowledged the assistance of the same administrator, Margaret. Noticing that these theses shared the same presentation and format style-with identical font, border, and layout-we saw material evidence that the documents were the work of one person and one machine. The likeness between the three also created an impression-reinforced by references across the same set of acknowledgements to Room 6027, a shared place of writing (Kelly \& Manathunga, 2020) — of a communal approach to scholarship in this department, involving the team of researchers and other members of the department, both academic and non-academic.

Acknowledgement of Margaret's input in these theses prompted us to reflect on and examine the distinctions thesis writers sometimes make between different types of writing tasks. The acknowledgement of "Margaret... for all those last minute corrections" (R, UA) implies more than a straightforward typing contribution and is closer to a form of input often attributed to supervisors. Similarly, the statement, "the first class job Margaret ... has done in typing this magnum opus ... from my unremitting scrawl” (T, UA) signifies her writerly agency, her knowledge of the subject area, and her capacity to interpret the work- her hand in the production of the "magnum opus." Similar contributions were acknowledged in the Melbourne data. One woman thesis writer fulsomely acknowledged the help of her typist in "translat[ing] my 
illegible, handwritten scrawl into neat typewritten words and mathematical text-and ma[king] a very good job of it indeed" (C, UM ). There were other examples from Melbourne where typists were thanked for going beyond typing skills: from "eliminat[ing] many errors and inconsistencies" (H, UM), to help with "references and proofreading" (E, UM), or "typing research reports and correspondence" (Ha, UM ). One contributor was not only responsible for "superb typing and proofreading" but also "for many of the excellently drawn diagrams" (M, UM). These comments prompted us to wonder-like Clark (2006) — where does correction end and collaboration begin? The data indicates it is not only the author who contributes to the content of a thesis; other contributors read the thesis and bring vocabulary, knowledge, expertise, and understanding of the subject to contribute to its final form, underscoring the connections between the mechanics of the writing process and the meaning of the text.

Notably, all the typists from the Auckland and Melbourne data were women. In both contexts, typing a thesis was sometimes the task of several women; in one set of theses from Melbourne across different disciplines, with authors of different genders, between three and six different women typists could sometimes be named. In Australia and New Zealand during the 2oth century, being a typist was a form of paid work as well as a role and identity for many women. Becoming a typist was also symbolic of being an independent working woman in Japan after the Second World War. A range of economic, social, and technological factors contributed to the evolution of the typist, including the growth in use of portable typewriters. According to Joost Beuving and Geert de Vries (2015), "millions of young women ... typed away at mechanical and electrical typewriters" (p. I46). In their heyday, typewriters opened a new sphere of work for women; the portability of typewriters enabled flexibility, and secretarial work was often limited in hours so it could fit around other commitments. Leah Price and Pamela Thurschwell (2005) suggested that the history of the typewriter is inextricable from the contestation and reinforcement of gender roles; it created employment opportunities outside the home but also invented a new sphere of 'women's work' to support 'men's work.' It was not until the late I980s that typewriters and typists were displaced as technological advancements led to the widespread adoption of personal computers (Burke, 20I2). Acknowledgements from this era are thus a marker of a significant-albeit waning - technological and social phenomenon bound up with academic writing practices.

The example of the typewriter shows that doctoral writing practices and ideas about who (or what) constitutes a writer are always linked to material conditions and technologies. Although manuscripts were not produced on 
typewriters when the Ph.D. came into existence, typesetting was a practice used in the production of academic theses even in the early igth century (Clark, 2006). In I829, Friedrich Ritschl produced his dissertation with the assistance of "three typesetters" who worked "through two nights to get the dissertation printed on time" (Clark, 2006, p. 234). At the end of the igth century, wrote Peter Burke (20I2), the typewriter came to be regularly usedaround the same time that higher education and the model of the research university also experienced rapid expansion. While administration centers were first to embrace this machine, universities and publishers also increasingly (although not universally, as handwritten examples from Keio attest) "came to insist on typescript rather than manuscript for books and $\mathrm{PhD}$ dissertations" (Burke, 20I2, p. 95). This necessitated someone, not necessarily the author, producing the typescript.

\section{Typing and the Division of Textual Labour}

Acknowledging the work of a typist or typesetter reveals a set of connections very different from reference to prestigious scholars and speaks to the idea that all work in the university is grounded in materiality. "By itself," Hannah Arendt (1958) wrote, "thinking never materialises into any objects. Whenever the intellectual worker wishes to manifest his thoughts, he must use his hands and acquire manual skills just like any other worker" (p. 90). Thought and hand are conjoined in Arendt's account of scholarship, yet writers are rarely imagined as intellectual workers possessing manual skills. According to Price and Thurschwell (2005), the tendency to separate out aspects of writing, to valorise mind over body, is nowhere more apparent than in the division of textual labour, which our analysis of acknowledgements reveals: Some people do the thinking, while others do the typesetting, typing, or proofreading. In our data, the former group comprised both genders while the latter consisted solely of women.

In these acknowledgements, the task of typing a manuscript was often referred to as laborious (B, UA). Although this phrasing implies recognition of and gratitude for the hard work involved, it also categorises this work as labour, with implications that it is manual, rather than intellectual, work. Again, we found evidence that textual labour was divided, hierarchical, and gendered: Tasks having to do with "thesis production" (P, UA) or the manual side of writing a text, such as proofing, were distinct from-rather than integral to-intellectual work. This is despite the fact that the range of tasks that typists engaged in could include correction, interpretation, drafting, drawing diagrams, finding references, and writing research reports and correspondence. 
Most theses in the Auckland and Melbourne dataset created a distinct order of acknowledgement, with a thesis production section at the bottom of the list after supervisors, fellow research students, international contacts, funders, laboratory and technical staff, and archivists and librarians. This order of acknowledgement enacts the idea that textual production happens only at the end, after the research is done. We found that final draft or final manuscript and last-minute were phrases used a number of times in relation to others' textual work, further reinforcing this idea. Sometimes the hierarchy of textual labour was conveyed through other means, as in the case of one thesis from the Keio dataset that included the titles and affiliations of all other contributors-except for the two women named for contributing diagrams. This ordering (and gendering) of labour creates what Price and Thurschwell (2005) referred to as a fantasy of detachment between transmission (the text or vehicle for ideas) and understanding (ideas) that is connected to an ageold division between material and metaphysical understandings of language and writing.

Although acknowledgements of typing and other text-related tasks often took the form of compliment or praise, these could also, through choice of adjective for example, reinforce a transmission/understanding dichotomy. We found many examples of phrases like (with our emphasis added) "her very competent typing of the labels and captions for the diagrams" (E, UA), "her efficient and accurate typing" (A, UA), and "excellent clerical assistance" (D, UM) that were grateful but also faintly denigrating. The typists were valued but put in their place. At the same time, the absence of a compliment also stood out as somewhat ungracious or revealing, as when someone simply "did the typing" (P, UA).

The nature of the acknowledgement and the choice of verb or adjective led us to thinking about the nature of the exchange between thesis writer and typist. On the one hand, typists were sometimes employed by the doctoral student's department-like Margaret in chemistry at Auckland—in which cases it was unclear if the typing up of a thesis was undertaken as part of paid employment or done as a favour-or something between the two. Reflecting further on this, we wondered about the absence of references to typists in the acknowledgements from Keio: Was this because in the Japanese context, a typist was considered a paid professional, so therefore it was not deemed necessary to acknowledge them in the same way one might when such work was carried out as a favour or as a gift? Using Japanese typewriters required professional training - there were around 2,400 characters on them (an English typewriter had around Ioo). Kazuchika Ota (2003) suggested that Japanese typewriters would have been found in administration offices in the university 
that and non-academic staff with training would have typed documents and manuscripts when necessary. Perhaps a secretary to a professor acted as a typist for a student's thesis. For example, in Professor Hitoshi Yoshida's memoir (as cited in Tanaka, 2or6), there was a description of the staff of Yoshida's chemistry laboratory buying a Japanese typewriter in 1980 in order to become the administrative hub for an academic society; the memoir also described how the professor's secretary typed society documents.

Conversely, we found instances in the New Zealand and Australian acknowledgements that showed when a typist was not a paid member of the department, she was often a friend or relative. Wives were thanked for work on the "first draft" (Pe, UA), for "typing the manuscript" and "proof-reading and colouring maps" (Pet, UA). One writer thanked his "mother for typing part of the first draft" $(\mathrm{D}, \mathrm{UM})$ - another his "sister Janne for typing the final draft" (Haw, UM). There were also times when wives were thanked for assisting with proofreading and improving the first draft - such as one Auckland writer who thanked his wife for "the help she gave with the onerous task of proof reading" (A, UA) and one from Melbourne who thanked his "wife Jan for the numerous improvements she made to the original manuscript and for a large amount of proofreading" (M, UM). Remind us, when is correction collaboration? Interestingly, in the Melbourne data, while most (but not all) of the women thesis writers acknowledged typists, none of them acknowledged their husbands for typing or proofreading or other tasks relating to the writing and preparation of the thesis.

While departmental typists were paid to do the work, mothers, sisters or spouses were usually not. This speaks to Beuving and de Vries'(2015) point that personal projects often rely on networks of family and friends who give their time and effort on the basis of reciprocity, or other informal yet meaningful exchanges, rather than payment. One thesis writer thanked someone for "being persuaded to type" (M, UM ). While a wife is "a cheap worker," there is also trust that comes with asking a close relative or friend to work on a thesis (Beuving and de Vries, 2015, p.I48). Some thesis writers acknowledged other kinds of support alongside typing, such as one from Auckland who cited "patient help and advice" from a relative named Margaret (Pet, UA). Although, predictably, women tended to be credited in thesis acknowledgements with providing what could be termed emotional labor, there were also references to "help and friendship" (S, UA) from men too. One woman thesis writer referred to "Donald's love, patience, critical acumen and painstaking care with the manuscript" in a rare reference to a combination of emotional, intellectual and manual support-although Janice was also named as an "excellent typist" (McM, UA). In contrast, an analysis of the Melbourne data set suggests that 
several of the women thesis writers acknowledged the emotional support of their husbands but never referenced their help with the manuscript.

\section{". . . to Sylvia for the Loan of the Office Typewriter": Writing and Technology}

One acknowledgement invited further reflection on the material practices of writing and research (Kelly \& Manathunga, 2020), as it included many references to objects, one of which was the office typewriter loaned by "Sylvia" (B, UA). In this acknowledgement, writing was not only imagined as a social activity, it was also material and technological. Paul Standish (1997) offered insights into the relationship between writers, writing, and technology and suggested that, rather than perceive the relationship between the knowing subject and an object-like the one a writer has with a keyboard—as objective and neutral, we should acknowledge the impact of what Heidegger termed ready-to-hand technologies on our capacity to work and think. While we may not always be particularly conscious about such objects, they nonetheless enable a "smooth functioning" for us (Standish, I997, p. 445). The word typerwriter, as Price and Thurschwell (2005) pointed out, can refer to a machine or a person. The three New Zealand theses in chemistry with identical extratextual elements were produced by one person and one machine.

Although the main thesis text allows a few glimpses of the writer's relationship to technologies, acknowledgements can make visible the contribution of objects that, like other people, enable doctoral scholars to do research and write a thesis. Something happens in the backstage moment of writing the acknowledgement: As writers reflect on the contributions of others, they are telling an alternative story of the thesis' completion. In this story, the presence and agency of objects and technologies, such as the office typewriter, also sometimes emerge. In the Keio acknowledgements, references to high-speed cameras and newly developed laboratory equipment for experiments reveal the range of technologies integral to the doctoral writer's research. In others' acknowledgements, such as several found in the Auckland set, humble and homely objects were referred to, from cups of tea to a vehicle that was particularly reliable. For the most part, however, thesis writers tended to overlook the things that support the work of writing, further contributing to the imaginary of the singular, solitary work springing from the mind of an author (Barthes, 1977) or from an ego (Kristeva, 1973). The danger of allowing the elision of our reliance on things and others in our contemporary, late-capitalist epoch is that we contribute to the idea that such work is smooth, easy, efficiently productive, and individual - all those qualities that our era of fast-capitalism demands and rewards (Peters, 20I5). 
Personal computers have contributed to the reduction in the time it takes to complete doctoral theses, and there has been a significant re-imagining in the last 30 years of doctoral writing as a result-with no need to write up a manuscript from a tangle of "unremitting scrawl" (T, UA) a thesis can be written anytime, anywhere by the doctoral candidate. We were struck by references in acknowledgements to how long research and writing took in 1980 (one from the Japanese data set took 20 years), which reminds us this was an era in which time was less compressed, scholarship less urgent. As Michael Peters (2015) has shown, speed and "fast knowledge" (p. I5) are hegemonic concepts in our "techno-epistemological" (p. II) era, deeply transforming the university.

Yet laptops and personal computers, and the smooth texts that are produced with them, perhaps disguise rather than eradicate the nature of writing as time-consuming work. By making less visible the relationship between thought and the hand, technology also makes it harder to acknowledge the relationship between understanding and transmission. We found many handwritten dedications and signatures, or corrections by hand - such as the application of liquid correction fluid - which do what Standish (1997) described as "the sort of revealing that technology would otherwise cover over" (p. 446). Crucially, concealing the work of writing makes it more "susceptible to the imposition of a calculative rationality" and subject to contemporary utilitarian demands, such as shorter timeframes to completion of degrees or greater numbers of doctoral theses per institution (Standish, 1997, p. 450). Looking at historical texts like these acknowledgements from 1980 makes more apparent the work that goes into writing: Because technologies were simpler, we can see the presence of a hand or another's labour in a way that modern technologies gloss over.

\section{Concluding Remarks}

Analysing doctoral thesis acknowledgements allows different stories about doctoral writing to emerge and enables us to reflect critically on the ways that writing is situated, the ways it involves textual labour that extends beyond the efforts of a single author. Writing involves intellectual work and it involves manual skill, although sometimes these elements are divided, with some tasks being performed by other people and/or things—contributions that can be elided in the name of an authorial scholarly text. Barthes (1977) commented that it suits a capitalist ideology to privilege the single author; Derrida (2004) pointed out that an author is a construct of the logocentric and ontological system of which the university is a part and to which it contributes. Academic writers work within these ideological and systemic constraints, yet it behoves 
us to find ways to resist them. In a recent blog entry, academic and historian of higher education Tamson Pietsch (2019) wrote that she was becoming more conscious of "expertise and its history and the ways that academics like me deploy it to underpin our knowledge and authority claims" in texts like academic biographies (para. I). These same texts can be written differently, she suggested, to make different claims about authorship and the situatedness of knowledge. Acknowledgements can likewise undo claims to tidy authorial-ness and make plain the other people and things that go into the work of writing a thesis. If writers can get better at challenging the single author imaginary, we might be able to contest some of the worst aspects of our individualistic academic traditions, point the way toward greater opportunities for "common action" (Pietsch, 20I9, para. I2), and resist the old hierarchies that dog our writing practices.

\section{Acknowledgements}

This work was supported by the Research Institute Higher Education (RIHE), Hiroshima University, Japan. The authors offer their sincere thanks to the research team in the overall project, including Barbara Grant, Cally Guerin, and Jules Skelling. They also thank all the unsung heroes that enable the work of writing.

\section{References}

Arendt, H. (1958). The human condition. University of Chicago Press.

Barad, K. (2007). Meeting the universe halfway: Quantum physics and the entanglement of matter and meaning. Duke University Press.

Barnacle, R., \& Dall'Alba, G. (2014). Beyond skills: Embodying writerly practices through the doctorate. Studies in Higher Education, 39(7), 1139-1149. https://doi. org/10.1080/03075079.2013.777405

Barthes, R. (1977). Image-music-text. Fontana Press. (Reprinted from Mantéia, 5, 1968.)

Beuving, J., \& de Vries, G. (2015). Doing qualitative research: The craft of naturalistic inquiry. Amsterdam University Press. https://doi.org/10.2307/j.ctt130h8g7

Burke, P. (2012). A social history of knowledge: Vol. 2 From the Encyclopédie to Wikipedia. Polity Press.

Chou, M.-H., Kamola, I., \& Pietsch, T. (2016). Introduction: The transnational politics of higher education. In M. Chou, I. Kamola, \& T. Pietsch (Eds.), The transnational politics of higher education: Contesting the global/transforming the local (pp.1-20). Routledge.

Clark, W. (2006). Academic charisma and the origins of the research university. University of Chicago Press. 
Derrida, J. (2004). Punctuations: The time of a thesis. In Eyes of the university: Right to philosophy 2. pp.113-128. Stanford University Press.

Eik-Nes, N. L. (2008). Front stage and back stage writing: Using logs to rehearse and develop a disciplinary role. Nordic Journal of English Studies, 7(3), 181-198. http://ojs.ub.gu.se/ojs/index.php/njes/article/view/158/156

Fairclough, N. (1992). Discourse and social change. Polity Press.

Genette, G. (1997). Paratexts: Thresholds of interpretation. Cambridge University Press.

Hashimoto, K. (1998). Wagakuni ni okeru igaku hakase no syakaiteki bunseki [Sociological analysis of M.D. in Japan: On an excessive grant of M.D. under the Act in 1920]. Research in Academic Degrees, (7), 63-77.

Hyland, K. (2011). Projecting an academic identity in some reflective genres. Ibérica, 21, 9-30. http://www.aelfe.org/documents/01_21_Hyland.pdf

Kelly, F. (2017). The idea of the PhD: The doctorate in the twenty-first-century imagination. Routledge. https://doi.org/10.4324/9781315707396

Kelly, F., Grant, B., Guerin, C., Manathunga, C., \& Sato, M. (2017, 6-8 November). The formation of academic identity in the university: Place, space and time [Paper presentation]. Philosophy of Higher Education Conference, Aarhus, Denmark.

Kelly, F., \& Manathunga, C. (2020). 'A flight over the study area': Ecological ontologies in doctoral thesis acknowledgments. Discourse: Studies in the Cultural Politics of Education. https://doi.org/10.1080/01596306.2020.1724078

Kristeva, J. (1973, 12 October). The system and the speaking subject. The Times Literary Supplement, 1249-1250.

McGann, J. J. (1992). The textual condition. Princeton University Press.

Ota, K. (2003). Nihongo wapuro hatsumei before and after [Invention of Japanese word processor before and after]. http://www13.ueda.ne.jp/ ko52517/t5.htm

Peters, M. A. (2015). The university in the epoch of digital reason: Fast knowledge in the circuits of cybernetic capitalism. In P. Gibbs, O.-H. Ylijoki, C. Guzmán-Valenzuela, \& R. Barnett (Eds.), Universities in the flux of time: An exploration of time and temporality in university life (pp. 9-31). Routledge.

Pietsch, T. (2019, July 17). Where I stand: Rewriting the academic bio. Cap and Gown. https://capandgown.wordpress.com/2019/07/17/where-i-stand-rewritingthe-academic-bio/

Price, L. \& Thurschwell, P. (2005). Invisible hands. In L. Price \& P. Thurschwell (Eds.), Literary secretaries/secretarial culture (pp.1-12). Routledge.

Standish, P. (1997). Heidegger and the technology of further education. Journal of Philosophy of Education, 31(3), 439-459. https://doi.org/10.1111/1467-9752.00067

Tanaka, S. (2016). Yoshida Hitoshi sensei to bunseki kagaku [Professor Hitoshi Yoshida and analytical chemistry]. Hokkaido Shibu News [Newsletter of Hokkaido Branch Office], 54, 4-5. http://www.jsac.or.jp/ hokkaido/ShibNews/Shibunews54.pdf

Thomson, P. \& Kamler, B. (2013). Writing for peer reviewed journals: Strategies for getting published. Routledge. https://doi.org/10.4324/9780203097076 


\section{Section Four: Writing a Re-imagined Doctoral Thesis}





\title{
11 Re-imagining Doctoral Writing Through the Visual and Performing Arts
}

\author{
Louise Ravelli and Sue Starfield \\ University of New South Wales \\ Brian Paltridge \\ University of Sydney; City University of Hong \\ Kong
}

Abstract: While doctoral writing in the broader academy is a site of anxiety and contestation (Paré, 2019), doctoral writing in the visual and performing arts inhabits an even more contested space. For social and institutional reasons, the visual and performing arts are relative newcomers to the practice of doctoral writing (Baker et al., 2009; Elkins, 20I4), and with theses that incorporate a creative/performed component, whole new ways of doctoral writing have opened up, including such features as new academic voices; highly innovative forms of typography, layout, and materiality; and varied relations between the written and creative components. Understanding such diverse texts requires a multi-valent approach to recognise the ways in which doctoral writing has been re-imagined in this context and the ways in which the academy can re-imagine a legitimate space for such academic work. In this chapter, we use a broadly social-semiotic framework to demonstrate the value of Legitimation Code Theory (Maton, 20I4) and genre and discourse analysis (Martin \& Rose, 2007; Paltridge, 202I) in understanding such diverse texts and their positioning within the academy. We report on an Australian study that examined 36 doctoral submissions across a range of visual and performing arts disciplines, demonstrating the underlying consistencies of these theses despite evident surface disparities. We argue that understanding doctoral writing as a practice of meaning-making potential helps lessen individual and institutional anxiety around such texts and provides productive ways forward for doctoral writing pedagogy for these disciplines as well as for the academy more broadly. 


\section{Stranger Than Fiction: The Diverse Forms of the Practice-Based Thesis}

Academic research is always a creative endeavour, no matter the disciplinary field. Even the driest experimental research following well established procedures requires a spark of originality, a gift of insight, or an element of the unknown, otherwise it would not be research. For doctoral candidates in all disciplines, this element of the unknown creates both the excitement of the project and the anxiety that comes along with it. The writing of the project adds another step into the unknown, at least for the candidate, for whom this is typically a once-only experience. While the writing process is never easy, some disciplines have developed clear expectations and pathways, which at least provide a scaffold for the candidate (see Thurlow, Chapter 5, this collection). In the visual and performing arts, where research is already more explicitly "creative," its relatively late arrival on the academic scene means that the pathways for research and writing are far less well established, and many studies point to the increased anxiety for students, supervisors, and examiners around the nature of doctoral writing in these fields (Baker et al., 2009; Fairskye, 1993; Hockey, 2003; Starfield et al., 2012). And yet, despite this anxiety, doctoral theses in the visual and performing arts evidence extensive re-imaginings of the nature of doctoral research and writing itself through variations in process, voice, structure, and form. Inspired by $\mathrm{Mi}^{-}$ chael Halliday's (1994) view of language as a resource of "infinite potential" for making meaning (p. I6), we argue that doctoral theses in the visual and performing arts are also a resource for making meaning. By viewing these theses in terms of their meaning-making potential, it is possible to evaluate them positively, rather than simply negatively, in comparison with more established doctoral forms.

This chapter reports on a study ${ }^{1}$ we conducted that analyzed doctoral theses in the visual and performing arts in terms of the nature of the writing that took place in these disciplinary contexts. Some doctoral theses in the visual and performing arts may be like theses in some other disciplines, in that the thesis is "about" another subject, such as a critical study of an artist. The theses we were interested in, however, were those that combined an explicitly created or performed work of the author with a written component. As we have noted elsewhere,

1 Paltridge, B., Starfield, S., \& Ravelli, L. (2008-2010). Writing in the academy: The practice-based thesis as an evolving genre (Grant No. DP0880667). Australian Research Council Discovery Project. https://dataportal.arc.gov.au/NCGP/Web/Grant/Grant/DP0880667 
the common denominator in these doctorates is the production by the student of both a creative work of some kind and a written text. Both pieces of work are evaluated as part of the doctoral examination process, and the term "thesis," in the visual and performing arts, is typically used to refer to the combined work. (Starfield et al., 20I4, p. I06)

In our study, we referred to these as "practice-based" theses, though other terms were used, such as "practice-led," "research as practice," or "performance as research," with significant debate around these and other terms (Paltridge et al., 20II). The term "exegesis," while common, is generally viewed negatively, being seen to construe the written work as a commentary upon the creative with little connection between the two (Paltridge et al., 20I2; Vella, 2005).

Practice-based theses are also distinctive from conventional theses in the regulations surrounding them, including the length of the written component (highly variable between institutions), the nature of the examination (which may be separated for the creative and written components), and claims for originality/contribution to the field that need to be substantiated in both components (Paltridge et al., 20I2). Ken Friedman (20I4) also notes that the pathways and preparation for doctoral study in the visual and performing arts are highly variable between countries, contributing further to the discomfort about their status.

The one overriding finding of our study was the immense variety of possibilities for practice-based doctoral theses in the visual and performing arts. It is hard to describe and impossible to explain just how beautiful, rich, and complex these theses can be. A visual arts thesis, for example, might create an immersive digital art and sound installation that envelopes the viewer in a multi-sensorial experience (e.g., Haley, 2005). A performance studies thesis might invite the viewer to (literally) follow the candidate on/in/to a performance, thus embodying the viewer as subject and as part of the research process (e.g., Fenton, 2007). Another visual arts thesis might have no physically separate visual component but might interweave visual components in the written component itself, perhaps through drawings, artifacts, or fragments of knitting (e.g., Van Niele, 2005; cf. Paltridge et al., 20I2). Another might be bound in beautiful embossed leather and velvet used to reframe an assemblage of drawings, photos, collage, and jewellery (e.g., Laird, 2009).

This diversity is not, however, an indication of instability, a lack of clarity in how to proceed, or a case of weak regulation. Rather, it is a productive and necessary outcome of the nature of these disciplines and their specific approaches to knowledge (Ravelli et al., 20I4). In this chapter, we explain the history of 
creative-practice doctoral theses in the visual and performing arts in Australia and other Western countries, the extensive variation in form they might consist of, and their underlying similarities despite this surface variation. It is by understanding their underlying meaning potential that institutions, supervisors, and students can better occupy this contested discursive space.

\section{Why So Unsettled? The Place of Visual and Performing Arts Within the Academy}

Our discussion of the place of visual and performing arts within the academy is limited to Western academic traditions, primarily in Australia but also in the UK and Western Europe, Canada, and the US. In Australia, while relatively recent in terms of academic traditions, the practice-based doctorate in the visual and performing arts is becoming reasonably well established. The first such doctorates emerged in Australia in the I980s following largescale reforms of the higher education sector that saw the amalgamation of teacher education colleges and art schools with universities (Paltridge et al., 20II). Around two thirds of Australian universities now have practice-based doctorates, and these programs see around 2,500-3,000 enrollments per year (Evans et al., 2003; Paltridge et al., 20II). Given that there are around 65,000 enrollments across all doctorates in Australia (Croucher, 20I6), the numbers for practice-led doctorates in the visual and performing arts are still small, but they are not immaterial. The pattern in Australia follows on from similar degrees in the United Kingdom about a decade earlier, and these two countries together account for the large proportion of such doctorates in the Western academy (Elkins, 20I4). The picture is less clear in Western Europe, where the diversity of institutions makes it difficult to ascertain numbers. In Canada and the United States, the Master of Fine Arts degree remains the predominant terminal degree in the visual arts, with the studio-art doctorate in its infancy (Elkins, 20I4). There are, however, examples of performing arts doctorates in Canada and the United States, such as the Doctor of Musical Arts degree in composition and performance at the University of Toronto and at Yale University, the latter having been on offer since 1968 (Noss, I968).

While creative practice doctorates may be relatively new in some regions, their more than 30 years' history in others has led to significant institutional and national-level debates around terminology, the codification of the nature and structure of these doctorates, and relevant processes and procedures for examination (see for example, Baker et al., 2009; Buckley \& Conomos, 2009; Fairskye et al., 2008; Phillips et al., 2008; Queensland University of Technology, 2008; Ravelli et al., 20I4). In our study, we turned to sociological theories 
of legitimation codes and linguistic theories of genre to investigate why this might be the case. In this chapter, we deal with legitimation codes and with genre in the following section.

Legitimation Code Theory (LCT; Maton, 2010a, 2014) builds on the sociological work of Basil Bernstein (e.g., 1996, 1999) and provides insights into how disciplines legitimate their approaches to both knowledge (objects and domains of study) and knowers (those who can engage in knowledge practices). As we noted in Doctoral Writing in the Creative and Performing Arts (Ravelli et al., 20I4),

a combination of knowledge and knowers can define a "legitimate gaze" (Maton, 2oIob, p. I55), whereby "knowledge claims and practices can [thus] be understood as languages of legitimation", or "strategic stances aimed at maximizing actors" positions within a relationally structured field of struggles" (Maton, 20Ioa, p. 37). No stance is more strategic in academia than that of a doctoral thesis: it is the ultimate "entry card" both to the discipline, and to the institution. (p. 394)

LCT posits that research is legitimated by different relations to the object of knowledge (epistemic relations) and by different relations to the subjects of knowledge (social relations; Maton, 20IOa, p. 45). One particular pattern or code of legitimation was the most common in our study-the knower code. The knower code is characterized by diversity in its objects of study and/or diversity in its approaches to study (weak epistemic relations) as well as by the privileging of experiential knowledge and an appropriate "voice" (strong social relations). That is, many topics may be legitimately pursued using a variety of approaches, with the subjectivity of the author being highly valued. This way of legitimating knowledge is in evident contrast to the knowledge code, where the objects of study are clearly defined (e.g., physics or chemistry), but where there is little personal discretion in how knowledge is pursued and where established procedures (e.g., to conduct an experiment, evaluate statistics) need to be followed (Maton, 2oroa).

It is the very nature of the knower code that contributes to the unsettled nature of doctoral theses (and research more broadly) in the visual and performing arts. ${ }^{2}$ As Karl Maton (2oroa) explains, knower codes are typically

2 This unsettled nature relates to the status of creative practice more broadly within the academy, for example in terms of creative works being recognized as research outputs. We can't address these factors in the confines of this chapter, but see, for example, Burgin, 2006; Fairskye, 1993; Haseman, 2006; and Trowler, 2012. 
associated with disciplines that have marginal institutional or academic positions. The relatively recent merger of art schools and colleges with universities contributes to this "outsider" status. Importantly, knower codes are characterized by a blurring and crossing of boundaries

between academic and personal; between the formal and the informal; between disciplines; between modes of presentation ... The object of study is not necessarily "an artwork"; it may be a feeling about belonging, or a problem in the interpretation of theatrical performance, or how photography can enable learning. The overarching framework might be one drawn from history, from cultural studies, from art theory, or from any number of other pre-existing fields. The methodology may be clear and derived from one of those pre-existing fields, or may be entirely new and invented for the purposes of that thesis. (Ravelli et al., 20I4, p. 398)

Intersecting with weak epistemic relations, the knower code is also characterized by strong social relations - the valorisation of individual experience and subjectivity. This defines a key part of the meaning potential of these theses: it is the sociality whereby knowers claim legitimacy within their field by asserting their voice, by developing and integrating new habitus (Bourdieu, I990; Maton, 20Iob, p. 164). However, rather than being a weakness, the weak epistemic relations and strong social relations open up the potential of the field by allowing for new objects of knowledge to be explored and for new ways of knowing.

Thus, the place of the visual and performing arts in the academy is seemingly unsettled not just because of an institutional history that positions these disciplines as relative latecomers or even as "gatecrashers" (Fairskye, 1993) but also because it is in the very nature of the field to be constantly reinventing and re-imagining ways to "do" visual and performing arts research. This is not a way of saying that the visual and performing arts are "more creative" than other fields, such as science. As Friedman (20I4) explains, "creativity is a human quality that we find among the best practitioners of most professions" (p. 244). Rather, the point about legitimation codes is that there are different ways of approaching and validating subject knowledge, and one of these, the knower code that tends to dominate the visual and performing arts, proceeds in a way that is quite different to that of knowledge codes. It is not that the visual and performing arts are "unsettled". Rather, it is that they "do" research in a different and unfamiliar way. 


\section{Fantastic Theses and How to Recognise Them}

Our three-year study aimed to identify and collect a representative range of doctoral theses in the visual and performing arts with the aims of better understanding them as textual products, better understanding their range of meaning potential, and better understanding how this places them within the academy.

As already noted in this chapter, there is wide variation in institutional practices around visual and performing arts doctoral theses and wide variation in the nature of the forms such theses may take. With regard to the written components of practice-based theses, we found these also varied widely in every possible form of presentation. Candidates may have presented their theses on standard printing paper, or with a careful selection of special papers with particular textures, colors, or opacities. These might be used throughout the text or in specific sections; in a systematic way or randomly. The font used for the writing might be a conventional one, such as Times New Roman, likely to be used with conventional punctuation, or something more contemporary, such as Avenir, which might be used with no or little punctuation, especially in headings. Or perhaps the thesis might include handwriting. A chapter might be 35 pages long or half a page. And so on. Such variation may seem to be trivial, being concerned with surface matters of presentation only, but these are in fact intrinsic meaning-making resources and are a fundamental way of positioning a thesis in relation to approaches to knowledge (such as traditional vs new humanities; see also Starfield \& Ravelli, 2006; Ravelli \& Starfield, 2008).

Actual images may or may not be included in the written component of visual and performing arts practice-based theses. One visual arts thesis had no images of the candidate's own visual arts practice in the written component; another had 500 (Paltridge et al., 20II). The images might be facsimiles of art works, hand drawn sketches, or thumbnail icons at the start of a chapter (Ravelli et al., 2013). Physical objects—-fragments of knitting, a hair, a mapmight also be included.

Given this wide variation in form, it is not surprising that finding these theses in the first place was not at all straightforward. We used textography, a modified form of ethnography based on work on academic genres by John Swales (1998; 2018). This included identifying the institutions and programs offering relevant degrees and conducting a survey of supervisors in which we sought recommendations of recent, successful theses they considered to be quality examples in their disciplines. In all, we collected 36 doctoral theses across the fields of painting, mixed media, drawing, digital media, photography, sculpture, dance, theatre, and music. ${ }^{3}$

3 See Paltridge et al. (2012) for a full description of the methodology. 
Our second challenge was to find "all" of each of these theses. Not only does the form of these theses vary as already mentioned, but also the creative work can be presented, encountered, and assessed in a variety of ways. In Australia, as elsewhere, there are no standard guidelines. Specifications for the written component vary among institutions, from requiring it to be the "major" component to requiring a specified number of words ranging from 20,000 to 60,000 (Paltridge et al., 20II; see also Elkins, 20I4, for further discussion of institutional requirements across regions). There is similar variation in relation to guidelines for the creative component, which either specify its relative weighting in relation to the written component (greater, lesser, or equivalent) or specify it in terms of its equivalence to a set number of words (e.g., 40,000 words) without articulating how this might be measured.

Variation between the practice-based doctoral theses was also evident in the way the written and creative components were explicitly related to each other - or not. We identified four recognizable types (Ravelli et al., 20I3) in terms of whether the two components were encountered (more or less) as separate or (more or less) as connected. The first (which occurred only once in our data set in Haley, 2005) was that of parallelism, where the written component shared the same thematic concerns as the creative component but did not make explicit textual or visual reference to it. The second relation was that of influence, where the written component referred to the creative component and asserted the same influences, but where there may otherwise have been little explicit connection (e.g., Le Guen, 2006). The third type was incorporated, where the written component referred constantly to the creative component and in multiple ways, perhaps to describe or illustrate a point or to act as the object of theorization (e.g., Oscar, 2007). This incorporated referencing was sometimes done through language by referring to the creative work and by incorporating such reference as a grammatical component of the sentence, or it was sometimes done visually with photos or other images that referred to the creative work. The final type was intermingled, where the written and creative components were encountered together, with the written being highly visualized (that is, with images, decorations, and so on included) and the visual including - potentially - the written, such as a poem embedded within a figure (e.g., Berridge, 2006).

Variation in the voice of the written component was also evident in our corpus. Some writers used a traditional academic voice-impersonal, formal, or technical—while others used a highly subjective and self-reflexive voice (going beyond the use of just first person "I" to comment on the writer's experience, history, activity, and so on). A poetic voice might be used, or a stream 
of consciousness. One voice might be used consistently throughout a thesis, or different voices at different points. As Jillian Hamilton (20I4) notes,

[the creative thesis is] a particularly demanding genre of writing. Unlike the traditional thesis, it requires the practitioner-researcher to adopt a dual perspective-to look both out towards an established field of research, exemplars and theories, and inwards towards the experiential processes of the creative practice. ... It requires the reconciliation of multi-perspectival subject positions: the disinterested academic posture of the observer/analyst/theorist, and the invested, subjective stance of the practitioner/producer. It requires the negotiation of writing styles and speech genresfrom the formal, polemical style of the theorist to the personal and emotive voice of reflexivity. (p. 37o)

Such diversity might suggest that the meaning potential of these theses is so vast that it is random. However, through an examination of generic structure and underlying rhetorical functions, it is clear that this is not the case and that there are distinct ways of making meaning within doctoral theses in the visual and performing arts.

\section{Same Same but Different: Similarities and Differences Within and Without}

The meaning potential of doctoral theses in the visual and performing arts is not random; rather it is socio-culturally constrained. Most importantly, even the most innovative theses "still need, in some way, to address the broader issues of what it is that characterizes successful doctoral writing" (Paltridge, Starfield, Ravelli, \& Tuckwell, 20I2, p. II). The primary focus of our study was on the nature of the written component, and in this respect, we found at least two important types of commonalities. The first of these is in overall generic structure: the typical "shape" or organization of theses as written components, referred to as their macrostructure. Typical macrostructures for doctoral theses include the "simple traditional" and "complex traditional" forms- the former based on one study, the latter on multiple studies-both of which include a typical Introduction-Methods-Results-Discussion (IMRD) structure. Another typical form is the "topic-based" structure, where a general introduction is followed by thematically-connected chapters pertaining to the main topic (Paltridge \& Starfield, 2020). In our analysis, headings alone could not be used to determine the nature of the macrostructure. One thesis (Fenton, 
2007) had topic-based chapter headings, but the chapter contents provided evidence that the overall doctoral research (both the written and creative components) constituted something more akin to a traditionally-formulated empirical study (Paltridge, Starfield, Ravelli, \& Tuckwell, 20I2). Even when the chapter headings appeared to bear no resemblance to more traditional theses, the contents often did fulfill similar functions, such as

the need to contextualize the research, the need to engage with theory, the need to place the research within a broader field, and the need to demonstrate the way/s in which the doctoral project moves the field forward. We found that while there was considerable variation in how the doctoral texts we examined were organized, they were still influenced by these expected requirements of doctoral dissertations. (Starfield et al., 20I4. p. II2; cf. Hamilton \& Jaaniste, 20Iо)

The second commonality we found among the theses is in terms of underlying rhetorical functions, as described for research more broadly by Susan Hood (2010). The core rhetorical functions we identified were research warrant, research capacity, research evidence, and research effectiveness. We found these may be distributed reasonably conventionally, as for a traditionally-structured thesis, or may be widely dispersed throughout the thesis. Their subcomponents and correspondence with more conventional thesis elements are presented in Table II.I.

Table 11.1 . Core functions of doctoral texts in the visual and performing arts and approximate correspondence with traditional thesis types.

\begin{tabular}{|c|c|c|}
\hline $\begin{array}{l}\text { "Simple traditional" } \\
\text { chapter headings }\end{array}$ & Function & Sub-components \\
\hline \multirow[t]{3}{*}{ Introduction } & \multirow{3}{*}{$\begin{array}{l}\text { Research } \\
\text { warrant }\end{array}$} & Validate object of study \\
\hline & & Demonstrate space for new knowledge \\
\hline & & Establish relevance of own contribution \\
\hline \multirow[t]{2}{*}{ Literature Review } & \multirow{2}{*}{$\begin{array}{l}\text { Research } \\
\text { capacity }\end{array}$} & Position study in relation to theory and/or \\
\hline & & $\begin{array}{l}\text { Position study in relation to practice (self and/or } \\
\text { others') }\end{array}$ \\
\hline Methods & & $\begin{array}{l}\text { Explain and validate research process and tech- } \\
\text { niques, including theory/practice nexus }\end{array}$ \\
\hline Results & $\begin{array}{l}\text { Research } \\
\text { evidence }\end{array}$ & Present study (practice, theory) as research \\
\hline Discussion & $\begin{array}{l}\text { Research } \\
\text { effectiveness }\end{array}$ & $\begin{array}{l}\text { Argue that research undertaken is a contribution } \\
\text { to theory and/or practice (of self or others) }\end{array}$ \\
\hline
\end{tabular}


In other words, we found that

the written component must be more than just "description": to be doctoral research, the written component must also motivate the study (in personal and/or artistic and/or theoretical terms); situate the practice (in an ongoing practical and/or theoretical tradition); engage with theoretical discussions relevant to the practice; and argue how the practice contributes to the relevant practical and/or theoretical (and/ or personal) trajectory. (Paltridge et al. 20I4, p. IOI)

What is important here is that the practice-based doctoral thesis does not need to be bound by strict convention in terms of organisational structure. The more traditional IMRD structure may work for some projects, and it may do so under recognisable chapter headings or under more inventive ones. For example, a music thesis with a reasonably conventional organisational structure had the chapter headings "Introduction, Transcendence, Methodology, Contextualisation, Forces, My mode of existence, Musical processes, Conclusion" (Vincs, 2002; see also Paltridge, Starfield, Ravelli, \& Tuckwell, 20I2, p. 8).

However, the structure of the thesis can also be radically reconfigured, so long as the underlying rhetorical functions are still met. This liberates the written component of the thesis from structural straightjackets and allows the candidate to be more experimental, so long as they understand and can demonstrate where and how their study meets all the requirements expected of research. The issue for meaning potential is that the underlying rhetorical functions are met in some evident way. One thesis in our corpus included an introduction that consisted of images of the candidate's mother's garden and descriptions of being in it, and this was a way of laying the ground for the remainder of the research (Sabadini, 2007). In the conclusion of another thesis (Baker, 2004), we previously observed that "the conventionally-expected components of re-stating the purpose of the study, providing a summary of the findings, or referring to the contribution the project makes to the field as a whole can be seen only by applying a generous analogous lens" (Paltridge, Starfield, Ravelli, \& Tuckwell, 20I2, p. 9); however, through reflection and the posing of key questions, this particular conclusion successfully revisited the earlier components of the thesis and addressed its contributions. A generous analogous lens, then, is one that looks for meaning, not formal structure, recognising that what any writing does is shape meaning potential for the purposes of the writer/reader, the discipline, and the culture.

The four key interrelation types between the written and creative components-parallelism, influence, incorporated, and intermingled-also tended to 
correlate with specific choices in voice, even if the underlying rhetorical functions were the same. The theses with more separated components tended to have more consistent use of a singular academic voice - largely impersonal, even when construed through the first person "I." The theses with more connected components, particularly the intermingled, tended to make use of a wide variety of voices. In one thesis, we observed a mix of academic, informal, autobiographical, descriptive, and poetic voices.

Similarly, the more intermingled the relation between the two components, the more likely it was that the creative component would be "brought into" the written in multiple ways: as an illustration of a point, a framing device between chapters, or a cohesive element across chapters (Ravelli et al., 20I3, p. 4I6). Overall, we found that in the intermingled theses, the written and creative components resemiotized (Iedema, 20Io) each other. In other words,

... there are multiple verbal and visual resources which enable the separate components of the thesis to be brought together, with differing degrees of strength. Through referring to the creative component, representing it visually within the written, giving it a voice or attributes, relating it to underlying theoretical concepts, the two components are brought together. Resemiotization occurs both verbally and visually [and] is not necessarily uni-directional. (Ravelli et al., 2013, p. 4I6)

The apparent visual and textual diversity in the written components of creative-practice doctorates, as well as their underlying rhetorical similarities, is explained in part by the dominance of the knower code in the visual and performing arts. As noted earlier, the knower code is inherently variable and premised in the subjective; it prioritises individual experience and validates diverse voices without circumscribing the object of study.

What is perhaps more surprising is that, despite the professed institution$\mathrm{al}$ and student anxiety over theses in the visual and performing arts, such theses are in fact united by a clear set of underlying rhetorical functions, which can be seen to be closely related to those of any traditional thesis. The underlying rhetorical functions of the doctoral theses create unity, even if students re-imagine and re-conceptualize the forms in which this can be achieved.

\section{Occupying the Academy: Ways of Re- imagining the Space of Doctoral Writing}

The relatively unsettled place within the academy of visual and performing arts doctoral theses arises from a failure of imagination. There is institutional 
failure to imagine other ways of validating knowledge and to imagine other ways of validly demonstrating such knowledge. If, however, the surface diversity of these theses can be understood in terms of their underlying and unifying meaning potential, then that diversity can be re-imagined as a resource, not a burden. Such a re-imagination needs to attend to multiple institutional processes and practices.

First, academic writing courses need to allow for more open approaches, "as open as the approach to creative practice/research itself" (Starfield et al., 20I4, p. II5). While generalised approaches to academic writing have definite benefits (cf. Lowry, 20I4), they do not allow for the diverse ways in which meaning potential can be manifested in doctoral writing of the visual and performing arts. Similarly, institutional guidelines for students and examiners must also account for differences, and not just in the more conventional cases. That is, guidelines must allow for the production of the written component to manifest diversity and creativity as much as the so-called "creative" component. As Iain Biggs notes (20I4), the visual and performing arts are communities of "transverse action" that work with the tensions lying between the "worlds of the arts and the university sector" (p. 4II). It not only makes sense, then, to adopt an approach to writing that is complementary to this tension, but in our experience, it is liberating for students (and supervisors) to be exposed to such an open approach. ${ }^{4}$

Second, the availability of successful prior models, and multiple instances thereof, cannot be underestimated. There are few easily accessible repositories of practice-based theses, and there is an urgent need for a central repository of good examples. At the time of our study, no such repository was available, and we are not aware of the creation of one since. While individual institutions and supervisors might accumulate their own examples, such a pool would necessarily be limited, and a collective pool of examples would enable the showcasing of more diverse examples, and the highlighting of multiple fields and disciplinary approaches. In our own experience of thesis-writing workshops for practice-based doctoral candidates, it is the availability of multiple examples which has the most powerful effect on the confidence of students to tackle doctoral writing in their own way, less burdened by received conventions of what a thesis "should" be. By showing students how others have successfully re-imagined the doctoral writing process, it opens up the space for them to develop their own meaning potential.

Third, the first and second strategies need to be underpinned by an understanding of the underlying rhetorical functions of all doctoral theses in terms

4 See Wilmot (2019) for discussion of knowledge codes in doctoral writing of the humanities and social sciences and the implications for writing pedagogy. 
of how research is motivated, understood, and expanded within particular disciplines. Both knowledge and knower codes have much shared meaning potential but manifest these in distinct forms and structures. Institutions need to recognise that typical generic structures have emerged in accordance with the knowledge code but that other structures, suited to other knowledge practices, are also relevant. Together, some innovation in doctoral writing supervision and pedagogy and some generosity in institutional understanding of diversity will help provide a more settled place for doctoral writing in the visual and performing arts within the academy and a better appreciation of the potential of these re-imagined forms.

\section{References}

Baker, S. (2004). Painting: A new critical voice-Serious pleasure [Unpublished doctoral thesis]. Curtin University of Technology.

Baker, S., Buckley, B., \& Kett, G. (2009). Future-proofing the creative arts in higher education: Scoping for quality in creative arts doctoral programs. Australian Learning and Teaching Council. https://1tr.edu.au/resources/DS7-624\%20Creative\%20 Arts\%20Baker\%20Melbourne\%202009\%20report.pdf

Bernstein, B. (1996). Pedagogy, symbolic control and identity: Theory, research, critique (Critical perspectives on literacy and education). Taylor \& Francis.

Bernstein, B. (1999). Vertical and horizontal discourse: An essay. British Journal of Sociology of Education, 20(2), 157-173. https://doi.org/10.1080/01425699995380

Berridge, A. M. (2006). Re-picturing my life [Doctoral thesis, University of Canberra]. University of Canberra Research Portal. https://researchprofiles.canberra. edu.au/en/student Theses/re-picturing-my-life-an-articulation-of-autobiography-memory-and-

Biggs, I. (2014). From another place: Notes on context. In L. Ravelli, B. Paltridge, \& S. Starfield (Eds.), Doctoral writing in the creative and performing arts (pp. 407422). Libri.

Bourdieu, P. (1990). The logic of practice. Stanford University Press.

Buckley, B., \& Conomos, J. (Eds.). (2009). Rethinking the contemporary art school: The artist, the PhD, and the academy. The Press of the Nova Scotia College of Art and Design.

Burgin, V. (2006). Thoughts on 'research' degrees in visual arts departments, Journal of Media Practice, 7(2), 101-108. https://doi.org/10.1386/jmpr.7.2.101_1

Croucher, G. (2016, November 17). It's time to reduce the number of PhD students, or rethink how doctoral programs work. The Conversation. http://theconversation. com/its-time-to-reduce-the-number-of-Ph.D.-students-or-rethink-how-doctoral-programs-work-68972

Elkins, J. (2014). Remarks on the studio-art PhD around the world. In L. Ravelli, B. Paltridge, \& S. Starfield (Eds.), Doctoral writing in the creative and performing arts (pp. 9-32). Libri. 
Evans, T., Macauley, P., Pearson, M., \& Tregenza, K. (2003). A brief review of PhDs in creative and performing arts in Australia [Paper presentation]. Australian Association for Research in Education (AARE) Miniconference, Newcastle, New South Wales, Australia. https://www.aare.edu.au/publications/aare-conference-papers/show/7973/a-brief-review-of-phds-in-creative-and-performingarts-in-australia

Fairskye, M. (1993). Frankly, I may be a genius, but don't call me Dale, I'll call you. Paper presented at Ornithology and Art? A Bird's Eye View of Conceptual Rigour in Contemporary Art Practice. Queensland Art Gallery, Brisbane, May.

Fairskye, M., Buckley, B., Elias, A., Arthur, T., Peterson, T., \& Taylor, A. (2008). Sydney College of the Arts Ph.D. review. University of Sydney.

Fenton, D. R. (2007). Unstable acts: A practitioner's case study of the poetics of postdramatic theatre and intermediality [Doctoral thesis, Queensland University of Technology]. QUT ePrints. https://eprints.qut.edu.au/16527/

Friedman, K. (2014). Now that we're different, what's still the same? In L. Ravelli, B. Paltridge, \& S. Starfield (Eds.), Doctoral writing in the creative and performing arts (pp. 237-262). Libri.

Haley, S. J. (2005). Mirror as metasign: Contemporary culture as mirror world [Doctoral thesis, University of Melbourne]. Minerva Access. http://hdl.handle. net $/ 11343 / 38739$

Halliday, M. A. K. (1994). An introduction to functional grammar (2nd ed.). Edward Arnold.

Hamilton, J. (2014). The voices of the exegesis: Composing the speech genres of the practitioner-researcher into a connective thesis. In L. Ravelli, B. Paltridge, $\&$ S. Starfield (Eds.), Doctoral writing in the creative and performing arts (pp. 369-388). Libri.

Hamilton, J., \& Jaaniste, L. (2010). A connective model for the practice-led research exegesis: An analysis of content and structure. Journal of Writing in Creative Practice, 3(1), 31-44. https://doi.org/10.1386/jwcp.3.1.31_1

Haseman, B. (2006). A manifesto for performative research. Media International Australia, 118(1), 98-106. https://doi.org/10.1177/1329878X0611800113

Hockey, J. (2003). Practice-based research degree students in art and design: Identity and adaptation. The International Journal of Art and Design Education, 22(1), 82-91. https://doi.org/10.1111/1468-5949.00341

Hood, S. (2010). Appraising research: Evaluation in academic writing. Palgrave Macmillan. https://doi.org/10.1057/9780230274662

Iedema, R. (2010). Resemiotization of a policy initiative: Promoting open disclosure as 'open communication about clinical adverse events'. In P.A. Prior \& J. A. Hengst (Eds.), Exploring semiotic remediation as discourse practice (pp. 139-155). Palgrave Macmillan. https://doi.org/10.1057/9780230250628_6

Laird, M. (2009). Remnant and reliquary: Fragmentary traces reconciled as object and knowledge. Reading and registering the artefact through material culture research and the lives of women, Australia 1788-1901 [Doctoral thesis, University of Technology Sydney]. OPUS. http://hdl.handle.net/10453/36654 
Le Guen, D. R. (2006). The development of the French violin sonata (1860-1910) [Doctoral thesis, University of Tasmania]. University of Tasmania Open Access Repository. https://eprints.utas.edu.au/7868/

Lowry, S. (2014). Strategies for artists becoming writers: Tackling the written component of practice-based research in the creative and performing arts (A report from the regions). In L. Ravelli, B. Paltridge, \& S. Starfield (Eds.), Doctoral writing in the creative and performing arts (pp. 337-352). Libri.

Martin, J. R., \& Rose, D. (2007). Working with discourse: Meaning beyond the clause (2nd ed.). Continuum.

Maton, K. (2010a). Analysing knowledge claims and practices: Languages of legitimation. In K. Maton \& R. Moore (Eds.), Social realism, knowledge and the sociology of education: Coalitions of the mind (pp. 35-59). Continuum.

Maton, K. (2010b). Canons and progress in the arts and humanities: Knowers and gazes. In K. Maton, \& R. Moore (Eds.), Social realism, knowledge and the sociology of education: Coalitions of the mind (pp. 154-178). Continuum.

Maton, K. (2014). Knowledge and knowers: Towards a realist sociology of education. Routledge. https://doi.org/10.4324/9780203885734

Noss, L. (1968). Yale University School of Music-Doctor of Musical Arts. College Music Symposium, 8, 42-43. https://www.jstor.org/stable/40373217

Oscar, S. (2007). Into this wild abyss: Learning through fabricated photographs [Doctoral thesis, University of Sydney]. Sydney eScholarship Repository. http://hdl. handle.net/2123/3965

Paltridge, B. (2021). Discourse analysis: An introduction (3rd ed.). Bloomsbury.

Paltridge, B., \& Starfield, S. (2020). Thesis and dissertation writing in a second language: A handbook for students and their supervisors (2nd ed.). Routledge. https:// doi.org/10.4324/9781315170022

Paltridge, B., Starfield, S., Ravelli, L., \& Nicholson, S. (2011). Doctoral writing in the visual and performing arts: Issues and debates. The International Journal of Art and Design Education, 30(2), 242-255. https://doi.org/10.1111/j.14768070.2011.01700.x

Paltridge, B., Starfield, S., Ravelli, L., \& Nicholson, S. (2012). Doctoral writing in the visual and performing arts: Two ends of a continuum. Studies in Higher Education, 37(8), 989-1003. https://doi.org/10.1080/03075079.2011.562285

Paltridge, B., Starfield, S., Ravelli, L., \& Tuckwell, K. (2012). Change and stability: Examining the macrostructures of doctoral theses in the visual and performing arts. Journal of English for Academic Purposes, 11(4), 332-344. https://doi. org/10.1016/j.jeap.2012.08.003

Paltridge, B., Starfield, S., Ravelli, L., Tuckwell, K., \& Nicholson, S. (2014). Genre in the creative-practice doctoral thesis: Diversity and unity. In G. Garzone \& C. Ilie (Eds.), Genres and genre theory in transition: Specialized discourses across media and modes (pp. 89-105). BrownWalker.

Paré, A. (2019). Re-writing the doctorate: New contexts, identities, and genres. Journal of Second Language Writing 43, 80-84. https://doi.org/10.1016/j. jslw.2018.08.004 
Phillips, M., Stock, C., Vincs, K., Hassall, N., \& Dyson, J. (2008). Draft recommendations for best practice in doctoral and masters by research examination of dance studies in Australia. West Australia Academy of Performing Arts at Edith Cowan University.

Queensland University of Technology. (2008). A handbook for postgraduate research students: Creative industries.

Ravelli, L., Paltridge, B., \& Starfield, S. (Eds.). (2014) Doctoral writing in the creative and performing arts. Libri.

Ravelli, L., Paltridge, B., Starfield, S., \& Tuckwell, K. (2013) Extending the notion of 'text': The visual and performing arts doctoral thesis. Visual Communication, 12(4), 395-422. https://doi.org/10.1177/1470357212462663

Ravelli, L. J., \& Starfield, S. (2008). Typography and disciplinary identity in academic writing. Information Design Journal, 16(2), 133-147. https://doi.org/10.1075/ idj.16.2.06rav

Sabadini, A. (2007). Exquisite corpse: The rainbow serpent in the Garden of Eden [Unpublished doctoral thesis]. Curtin University of Technology.

Starfield, S., Paltridge, B., \& Ravelli, L. (2012). 'Why do we have to write?': Practice-based theses in the visual and performing arts and the place of writing. In C. Berkenkotter, V. K. Bhatia, \& M. Gotti (Eds.), Insights into academic genres (pp. 169-190). Peter Lang.

Starfield, S., Paltridge, B., \& Ravelli, L. (2014). Researching academic writing: What textography affords. In J. Huisman \& M. Tight (Eds.), Theory and method in higher education research II (Vol. 10, pp. 103-120). Emerald. https://doi. org/10.1108/S1479-3628(2014)0000010011

Starfield, S., \& Ravelli, L. J. (2006). "The writing of this thesis was a process that I could not explore with the positivistic detachment of the classical sociologist": Self and structure in New Humanities research theses. Journal of English for Academic Purposes, 5(3), 222-243. https://doi.org/10.1016/j.jeap.2006.07.004

Swales, J. M. (1998). Textography: Toward a contextualization of written academic discourse. Research on Language and Social Interaction, 31(1), 109-121. https://doi. org/10.1207/s15327973rlsi3101_7

Swales, J. M. (2018). Other floors, other voices: A textography of a small university building (20th anniversary ed.). University of Michigan Press. https://doi. org/10.3998/mpub.9859761

Trowler, P. (2012). Doing research: The case of art and design. In P. Trowler, M. Saunders, \& V. Bamber (Eds.), Tribes and territories in the 21st century: Rethinking the significance of disciplines in higher education (pp. 68-77). Routledge.

Van Niele, I. (2005). Ambivalent belonging [Doctoral thesis, University of South Australia]. UniSA Research Outputs Repository. https://ap01-a.alma.exlibrisgroup.com/view/delivery/61USOUTHAUS_INST/12146657950001831

Vella, R. (2005). Keeping the degree creative. Realtime, 68, 2. http://www.realtimearts.net/article/68/7916

Vincs, R. (2002). African heart, Eastern mind: The transcendent experience through improvised music [Doctoral thesis, Deakin University]. DRO. http://hdl.handle. net/10536/DRO/DU:30023145 
Ravelli, Starfield, and Paltridge

Wilmot, K. D. (2019). Enacting knowledge in dissertations: An exploratory analysis of doctoral writing using legitimation code theory [Doctoral thesis, University of Sydney]. Sydney eScholarship Repository. http://hdl.handle.net/2123/20498 


\title{
12 Fictional Writing in Doctoral Theses: The (re)Engagement of Play and Reflexivity
}

\author{
Will Gibson \\ University College London
}

\begin{abstract}
In this chapter, I make the case for experimenting with fiction in doctoral writing in terms of both writing process and product. Experimentation with fiction involves playing with different ways of telling research stories, be they stories about the data itself or about the research process. Fiction offers doctoral students different ways to speak about affect, their relationships with participants, contradictions, messiness, uncertainties, and more. I draw attention to the potentials of using fiction as a process of sharing and (de)constructing knowledge in group settings and to its value as an alternate to conventionalized forms of academic language, particularly in terms of the representation of data. In short, fictional representation provides a way of playing with the doctoral performance and a further exploration of the ways language is used to make claims, position the author, and represent the social worlds being researched.
\end{abstract}

\section{Fiction and Social Research}

The use of fictionalized accounts is a well-established practice in social research and is just one of a number of writing forms that contribute to the creative turn in academic writing where aesthetics and voice are of key concern. Narrative research (Netolicky, 20I5); arts-based research (Chilton \& Leavy, 20I4); and numerous iterations of ethnography such as creative analytic process ethnography (Richardson \& St. Pierre, 2005), performance ethnography (Alexander, 2005), new ethnography (Goodall, 2000), and autoethnography (Anderson, 2006) are all areas where this kind of creativity can be seen.

Fictionalisation and concerns with the boundary between fiction/non-fiction can be found in a lot of these works, but as the list implies, ethnographers have had a particularly long-standing interest in it. The ethnographic novel is a genre that has its origins in the Igth century (Narayan, 1999), and it remains 
a common form. Contemporary work uses ethnographic fiction not just in the form of novels but also in shorter pieces (Sparkes, 2002). In ethnographic fiction, the border between fiction and non-fiction is deeply blurred, as the stories presented are offered as examples of real phenomena that have been witnessed during research. Ethnographic novels and essays have been used by academics to examine diverse areas of social life, such as homelessness (Augé, 20I3; Christensen, 20I2), professional identity and expertise (Müller, 20I7), educational experiences of the underprivileged (Clough, 2002), drug addiction and treatment (Elliott, 20I4), and anorexia (Kiesinger, 1998). Another strand of this work is the concern with historical processes, such as early 20 th century migration (Bahari, 202I) or education in the US (Gerla, 1995).

The reasons why fiction has been so important to ethnographic novels and essays has already been discussed in detail by other authors (Banks \& Banks, 1998; Gibson, 2020; Rinehart, 1998), so I shall review these points quickly. The fictional turn must be seen as part of a broad set of methodological critiques within qualitative research relating to both the crisis of representation (Denzin \& Lincoln, 2005) and the crisis of voice (Jackson \& Mazzei, 2009). Diverse areas of theory including Indigenous methods (Denzin et al., 2008), queer theory (Plummer, 2005), critical race theory (Delgado \& Stefancic, 2017), non-representational theory (Vannini, 2015), performance methodologies (Dirksmeier \& Hellbrecht, 2008; Richardson, 2015), post-qualitative inquiry (St. Pierre, 20I8), and post-feminist theory (Lykke, 20I4) — to name but a few-have had substantial input into these debates. The crisis of representation refers to the denial that the complexities of social life can be "captured" and presented as defined and bounded descriptions that stand or account for the fluid, negotiated, improvised practices/experiences/interpretations that comprise people's daily dealings. This denial emphasises the interpretive nature of social life, research practice, data analysis, writing, and reading and points to the impossibility of treating any "report" (from a researcher, research participant, or anyone else) as anything other than one telling in an (infinite) range of possible others.

Closely related, the crisis of voice refers to a drive, particularly from critical inquiry, to give voice to research participants while avoiding simplified "single truths" and showing the "polyvocal and multiple nature of voice within contexts that are themselves messy and constrained" (Jackson \& Mazzei, 2009, p. I). Critically, researchers are seen as central to the process of constructing these voices, and data in the form of quotes, fieldnotes, or even videos are seen as limited and partial. There is, it is suggested, a "tyranny of evidence" in traditional qualitative enquiry, where interview transcripts are held as evidence for social phenomena and/or for the researchers' re-interpretation of these texts: 
Who decides what 'exact words' should be used in the accounts? Who was listened to, and how were they listened to? How might voices be necessarily complicated, distorted and fictionalized in the process of reinscription? And indeed, how are those voices necessarily complicated distorted and fictionalized in the process of reinscription? (Mazzei \& Jackson, 20I2, p. 746)

The reference to fiction in this quotation is telling, as it shows that fictionalized accounts must be seen as a rejection of treating data as a transparently obvious "phenomena." The turn to fiction is a rejection of specific methodological claims and part of a broader process of re-imagining academic practices of writing, representation, and "evidencing."

The remainder of this chapter looks at specific ways that fiction can and has been used in doctoral writing. My discussion includes examples from doctoral theses and the occasional example from other published works by established scholars. These latter examples are included where I see them as offering something particularly relevant in thinking about the role of fiction in doctoral work. I also draw on my own experiences in working with doctoral writers and the ways that we have used fiction to leverage different kinds of research stories and representations.

In the next section, I explore the uses of fiction in doctoral writing and then move to discuss practical uses of fiction by thinking about the concepts of "character" and "scene," showing how these can help to tell research stories. I then reflect on the use of stories as a feature of producing collaborative and reflective doctoral experiences.

\section{Fiction and Doctoral Writing}

While I have not conducted a systematic review of the uses of fiction in doctoral writing, my searches of doctoral theses published in English illustrate that fiction is a well-established writing genre in doctorates of the arts such as film studies, drama studies, and literature studies. In the social sciences, fiction is much less common and seems to be used mostly in the areas of anthropology/ethnographic inquiry or in the "post-" paradigms described in the previous section, with education studies being a particularly prominent area (Burford, 20I6; Müller, 20I7; Petersen, 2007). However, as a comparatively new practice, there are important outstanding questions regarding the academic disciplines where fiction is most commonly found and the theoretical frameworks that inform its use. 
Of the doctoral writing I have analysed, the turn to fiction is frequently framed in terms of a frustration with the conventions of doctoral thesis writing (Burford, 2016; Kara, 2013), an interest in exploring the sensory and emotional character of social life/experience (Okoronkwo, 20I8), and/or an aim of presenting authentic narratives (Warren, 20I8). By writing with fiction, $\mathrm{Ph} . \mathrm{D}$. students alter discursive forms or "ways of knowing" (Lovat et al., 2008) within a thesis and, consequently, shift the boundaries of expertise that inform its production. As supervisors are not commonly practiced or trained in fictional writing (Gibson, 2020), there may potentially be a change in the role they play in shaping the thesis. Indeed, it is precisely an awareness of the complex politics surrounding the writing relationship that drives many researchers towards fiction, usurping or at least playing with the conventional division of expertise (Kara, 20I3; Weatherall, 20I9). Further, using fiction in a thesis raises critical questions about the examination process and the criteria of assessment. As has happened in relation to professional/work-based doctorates (Costley, 2013), the change in boundaries of expertise within other doctoral writing indicates a need to explore the processes of assessment of that work (see Ravelli et al., Chapter II, this collection). This is a debate that has yet to be held in earnest in relation to the use of fiction in doctorates, but it is one that is in urgent need in the context of the re-imaginings that I propose here.

\section{Characters and Scenes}

As narrative researchers have emphasised (Chase, 2008), when we talk about the people that we research, we create myths about them-partial re-orderings of selected bits and pieces of information (data) constructed as cases and representations. These tellings are myths not only because of the limits of language but also because of the normative practices that structure how we write. In a doctoral thesis, the normal structures of presentation radically constrain how we can talk about people (Aitchison, 20I5; Honan \& Bright, 20I6; Weatherall, 2019), but fiction provides an alternate set of practices, opening up what we can say about the participants in our research. Neil Carey's (2014) reflections on his use of creative fictions in his doctoral thesis about naming and meaning making in male "same-sex genital relations" made the point vividly:

I adopt this form of writing as a means of taking seriously the idea that representing biographies is far from straight-forward, that the selves that tell and are told in biographical and autoethnographic writing are themselves fictions, and 
that such selves can be (re-)inscribed against those narrative tropes that dominate the cultural milieu in which present and future 'self' might find itself located. (p. 2)

Thinking of participants as characters is a way to both recognise and experiment with the ways that narrative tropes structure our tellings. Characters in stories live in contexts, and describing those contexts through fiction enables us to make available (in an imagined way) the lives of the people under study. As Eva Bendix Petersen (2007) put it in her ethnofictive work, the "protagonist is a factual fiction or a fictional fact, a bodied figure, who sweats, laughs and eats, yet she is not 'real', not 'there"' (p. I47).

"Characterisation" is often used to create composite characters that stand for phenomena found across the data. One example of this technique is Petersen's 2007 journal article, in which she published her ethnographically based thesis. In it, she explored the performance of academic identity by imagining an average workday for an academic as follows:

She picked up her diary. Lecture at Io:oo, then coffee with Sandra. The nerve under the right eye twitched. Then teaching at $\mathrm{I}$, and then at 4 meeting with the new postgraduate student who had asked if she would supervise him-what was his name, ah, Adam. That meant that she could look at that peer-review report she was supposed to have finished yesterday now, and look at the grant application between teaching and supervising. Won't be time to do any actual writing today, she thought, and felt the usual acidic pang in her abdomen. Oh, and call John to set up that meeting, and give Jane instructions on copying, and I really ought to look at that book review which was due last week. And I have to see to getting my heater fixed, she thought. And that draft Paula had sent her a week ago; she had to read it before their meeting tomorrow. Sitting there, looking down on her diary, she already felt quite drained. And these were her precious morning hours when her head was supposed to be fresh. She turned to the article lying on top of one of the piles of paper on her desk. (Petersen, 2007, p. I75)

The character depicted in this excerpt was not a real person but a way of representing the general experiences/phenomena of the participants in Petersen's study. Petersen showed the character in a real-world context, depicting the tensions that existed between her and her colleagues/friends; the ever-present 
performance of "being an academic;" and the ways in which this manifested in teaching, casual talk with colleagues, commenting on students' work, discussing research projects with doctoral students, and the micro-politics of academic departments. In Petersen's narrative, she walked the character through her day, showing her conversations as well as her own internal dialogue around them. The structure of the narrative makes visible the lived feelings of the main character and the ways those feelings emerge in particular contexts and events.

Of course, characters can also be used to show the experiences of specific participants rather than a generalized group. The next example comes from Elizabeth Krause's (2009) study of Italian weavers, which was not a doctoral thesis but which used a very unconventional structure that has a lot of potential for doctoral work given the extended form of both genres. In this book, Krause combined fiction and conventional ethnographic narrative, with the two genres intersecting in thought provoking ways. This combination can be seen in the opening paragraph:

Emilia Raugei was a young girl who wove plaits of straw in a hill town above Florence, and the foggy March day she had her heart set on winning a weaving game of the girls' invention. Only seven years old, she willed her fingers to maneuver straw strands for hours as she sat on a straight-backed chair in a circle with a group of girls, her head being over her work and her arms immobile. Some six meters of woven plaits, five centimeters wide, formed rings at her feet. (Krause, 2009, p. I7)

Krause began the text with the girl, Emilia, who was at the center of the story, a character based on a real person the author came to know through conducting the research. In this paragraph, Krause described the scene of Emilia's work, set up a particular context (Florence on a March day), explained some of her motivation (to win the game), invoked specific features of the setting (the straight-backed chair and the group of girls), and characterised aspects of the physical action (her immobile arms). As the story unfolded, Krause went on to deal with complex issues, such as the rise of fascism, industrialisation, urbanisation, and how these social phenomena played out in the everyday lives of the characters. These phenomena were not presented as abstract theoretical constructs. Instead, they were shown as real processes that were connected with the life of the girl and her family.

In the second half of the book, Krause (2009) described the research that informed this story, including how she met Emilia, the relationship that de- 
veloped between them, and the pragmatics of recording and gathering data. It is interesting to reflect on how these imagined conversations, narrative plots, aesthetic descriptions, and sensory qualities impact on the experience of reading the ethnography. I found that the story helped me to develop a much more intimate sense of the setting and the historical conditions than ethnographic narratives typically do. When reading the ethnography, I felt that I already knew Emilia and that I understood something of the village in which she lived. Doctoral theses provide good contexts for these kinds of writing explorations because, in pragmatic terms, having large amounts of narrative space to present data in different ways means that the type of structure Krause modeled can become a real possibility.

Characters can also work to represent concepts and theoretical ideas. One of the exercises I use in doctoral writing workshops involves encouraging students to describe a concept using an invented character. One student who was researching the educational experiences of Syrian children displaced through conflict created the concept of "the dark lord" as a representation of children like "Omar" who lived with trauma:

Omar: I first encountered his presence when I was at that barrack, with all these dead bodies around me, with all the blood and the beheaded corps. I was shocked, full of questions, and I felt sick to the bone ... a at that exact moment, I felt him, he stood there, looking at me, grinning in the most hateful manner, and I knew I could do nothing but let him take all over me, so ... he just did.

When I moved to Turkey, I thought I got rid of him, but no. ... In the end, he knew I was still suffering, and I knew that he fed on my agony, and so it was ... he just lingered there. I could see him laughing and teasing me every time I was told off by people I worked for, and every time I stood at the school gate, wishing I was inside one of the warm classrooms rather than selling paper tissues in the cold streets of Istanbul.

In the extract, we see how the character followed the child and intimidated and oppressed him ("laughing and teasing me").

In the next extract, the same student researcher used the same character to make sense of the child's own behaviour:

It was in one of Omar's Spanish classes, when I first noticed the dark lord's presence. Omar was struggling with the 
teacher's instructions, so my advice was for him to ask the teacher for assistance; however, instead of helping Omar, the teacher told him off. It was then when I saw the dark figure, smiling, while grabbing Omar's hand, pulling him out of our world, and dragging him to his gloomy world.

By metaphorically representing the dark lord through depictions of "darkness" and "worlds," the student researcher illustrated the child's experience of trauma and showed the alienation created by the teacher's treatment of the child. Because these concepts were presented as a character, we come to see alienation and trauma not as abstracted concepts but as lived, embodied, and interactionally tangible experiences.

"Scenes" are the spaces writers can use to show the contexts characters live in and to narratively play out the experiences that are the focus of our research. One of the substantial critiques of qualitative approaches, such as thematic analyses, is their tendency to remove contact from view-to present quotations as if they have no relation to a real-world context of talk (van Manen, 1990). Ethnography, particularly in contemporary "creative forms," does much better at (re-)building the research scenes by selecting details of context to place people within real places (Elliott \& Culhane, 20I6; Pandian $\&$ McLean, 20I7). I see fiction as nothing more than an extension of this phenomenon and an embracing of creative form to build resonant places (Banks \& Banks, 1998).

In her thesis, Peggy Warren (2018) provided a resonant example of scene building by using the description of an imaginary scene on a beach to situate a conversation between some of the characters involved. She wrote:

On the sandy beach of Negril under the scorching sun, eight hopeful couples and two single men are discussing their future dreams. Though the motherlan' has been at war and times are hard, the earth still produces food for survival. Saltfish is sparse but they clubbed together their rations to get enough food to bring and share. Yam and saltfish are buried beneath the hot coals in de sand. The redemptive lyrics of reggae music invigorates the dreamers. Motherlan' calls and the pull is 'trong. As the gossip goes, motherlan' streets are paved with gold. The men lie face down on the beach, in unison they repeat the common dream that Ganja man has written in the sand.

'We go, we earn, we learn, we return.' 
Reggae beats are followed by the ballads of the blues. Brooke Benton, Ella Fitzgerald and Sam Cooke are amongst the great musical story tellers. Each story resonates with someone in the group. As the ballads resound, the men rise and 'drop foot'. The women look on and giggle. Everyone's happy. In the ice box is cool aid [sic], rum punch, Dragon stout and Red Stripe beer. (Warren, 2018, p. I28)

I see life abounding in this description: food, music, accent, weather, dance, emotions, and brands. These things are important to people, so much so that we can think of them not as "mere details" but, rather, as the stuff of life that makes culture/people/experience more visible. These specificities, in a novel and in creative writing, make the scene feel real and authentic (Leeke, 2020). As Warren herself emphasised, these are things that are important to the participants, and including accounts of them re-inscribes their meaning into the accounts, making them both accessible and recognisable.

\section{Collaboration and Critical Thinking}

Philip Leeke (2020) has pointed out that fiction can play an important role in critical thinking and exploration. When we tell stories, we produce cultural narratives, making visible often taken for granted ideas about the people and social worlds we are exploring. Similarly, when we read stories, we interpret those narratives, assessing their legitimacy, accuracy, and plausibility. As Leeke (2020) has suggested,

Who is telling the tale and why are they telling it? How reliable are they as tellers of the tale? Does ignorance, fear or ambition influence their reportage? What are they telling you and what is their behaviour showing you? This is the vocabulary of every creative writing class I have ever entered. (p. 202)

Through such questions, we can use fiction to put our representations (of people and their talk/actions/claims/rationalisation) under the microscope, making visible clichés, assumptions, and (over-)simplifications, and, perhaps, moving towards accounts that are rich in detail and that show complicity and nuance.

This idea of critical engagement is not unique to fiction, of course, and it is found in many of the post-realist paradigms referred to previously in this chapter. More generally, this kind of critique is strongly related to no- 
tions of reflexivity in the social sciences (i.e., critically exploring the relationship between the writer and the words they are writing or claims they are making with the context, people, problems being researched) and of intersectionality in feminist writing (Lykke, 2014). So, the analytic possibilities of fiction are not exclusive to it. However, asking students to write and, importantly, to share and talk about their stories in a group setting is a useful way to open up research to public scrutiny. When doctoral students talk about their research, it is common for methodology and method to become the focus: the data collection, sampling, issues of access, and so on. These are, of course, important topics, but they can very easily dominate the conversation. When fictions are presented and discussed, the data and story itself becomes the focus.

A useful activity I commonly draw on is to ask students to write a short story about one aspect of their findings. The students share this story with a small group of up to three students who read each other's work. I then present them with some conventional tools used to analyze fictional stories, such as plot and character arcs (Weiland, 20r6), and invite them to use these ideas to analyze each other's work. One part of the exercise involves mapping and re-drawing the story they have read. Students draw a map of the organisation of the plot in order to think about what the tension points are, when the moments where we learn important information occur, and what the resolution of the story is. I invite them to try to think of an alternative structure for the plot, such as by starting with the ending, by revealing the information in a different order, or by creating "cliff-hangers" and other structural tension points.

Through this exercise, participants come to focus on the thesis as a story and to think about what they want to say, their own assumptions about the data, and the ways that readers might interpret the claims being made. In most cases, the students do not use the stories in their final thesis, but the critical thinking in the exercises and the focus on representation are invaluable even in less experimental thesis work.

\section{Reflexivity}

The journey through a doctorate is a highly emotive experience involving the exploration and transformation of one's identity as a writer and researcher (Hallowell et al., 2004; Herman, 2010). We all use stories and metaphor to make sense of our experience, and it is useful to interrogate these stories to understand how we are making sense of things. Barbara Kamler and Pat Thomson's (2006) study of doctoral students' experiences as writers involved 
looking at the metaphors they used to describe the process of writing. The students' descriptions used metaphors that highlighted confusion, danger, puzzles, and mazes - metaphors that drew attention to the troubles and difficulties of writing. Kamler and Thomson (2008) later proposed an alternate metaphor of a dinner party to try to create a new relationship with the writing process:

The party occurs in one's own home, in the familiar territory where one belongs (not the ocean, or the swamp, or the dark tunnel). The candidate invites to her table the scholars with whom she wishes to engage in dialogue. The emphasis is on the company and the conversation. The candidate has selected the menu, bought the food, cooked the dishes which she offers her guests. As host to this party, she makes space for the guests to talk about their work, but in relation to her own work. Her own research/thesis is never disconnected from the conversation, for after all it lies on her table. It is part of the food the guests eat, chew and digest. (p. 6)

Extending this metaphorical idea further to thinking about fiction helps us see how fiction can become another way to explore the experiences of being a doctoral student/researcher. Ruth Weatherall (2019) used this approach in her own doctoral work, noting,

I wrote stories pretending that I was one of my participants (Richardson \& St. Pierre, 2005) and wrote stories and poetry about my own experiences. I also frequently shared my writing with my participants and talked about how and why I would have written in that way. And so, my writing started to take shape, situated among many different voices. (Weatherall, 2019, p. 106)

A concrete example of such writing is Helen Kara's thesis, published as a journal article in 2013, which follows in a tradition of using fiction to show the emotional character of research experience (Banks \& Banks, 1998; Christensen, 20I2; Lancione, 20I7). In it, she created an invented dialogue between her alter ego, named Polly Semic, and two fictional deities to explore the emotions of doctoral writing. In the following extract-which is intersected with formal academic references due to the conventions of the journal that later published it-Kara has placed Polly in dialogue with Pohed (one of two deities) discussing the ways that writing conventions can seem to force themselves onto the writer and to marginalise the author's own voice: 
'But I'm so stuuuuuuck,' Polly wailed.'I can't see how I'm ever going to get started with this chapter. Suddenly I have to do everything differently. These stupid academic writing conventions, they make it all so artificial' (Davidson, 2000, p. 124).

'Writing is always artificial' (Magrs, 200ra, p. 227; Winter et al., 1999, p. 7) Pohede said gently. 'What's really troubling you?'

Polly drew a trembling breath.

'What I think, and more to the point, what I feel, has been completely marginalised in the context of this research over the last few years. Even by me. I should have kept more notes. But I've bought in to this whole academic cognitive thing that I don't believe in. It's been like a process of assimilation, and I - I just don't want to be assimilated' (Groom, 2000, p. 73).

A tear slid down the side of her nose and she wiped it away. 'I guess I thought that at doctoral level there would be more scope for individuality.' (Kara, 2013, p. 75)

In this dialogue, I find Kara's (20I3) writing performs a self who is self-doubting, uncertain of how to resolve issues, and, fundamentally, emotionally challenged by the process. The writing contrasts strongly with more formal academic style. As Eileen Honan and David Bright (2or6) have noted, "the language of bureaucratic transmission - is the hegemonic language of the doctoral thesis" (p. 736), and bureaucratic language is not typically a good resource for communicating emotionality, doubt, discomfort, and ambiguity - certainly not in ways that make those things performatively evident. In his reflections on the value of fiction, Leeke (2020) noted,

A logical proposition and syllogistic reasoning helps me understand that something in the social world is true ceteris paribus, but dramatic writing allows me to grasp its emotional weight. This is why great novels are more compelling and immersive than bullet pointed, PowerPoint lectures. (p. 20I)

\section{Conclusion: Fiction and the Re-imagined Doctorate}

The re-imagining I propose here involves thinking about doctoral writing as playful and experimental, as a process of "thinking through," of doing thought and exploring rather than of simply representing thinking. Lan- 
guage is always a game of some sort-a game of playing with ways of representing ideas. Writing doctoral dissertations is "... a profound rhetorical, linguistic, intellectual, emotional, and psychological challenge” (Paré 2org, p. 8I), and the writing process is central to these challenges (Russell-Pinson \& Harris, 2019). Particular issues that doctoral students face in their writing journeys are developing creativity (Thurlow et al., 2org; see also Thurlow, Chapter 5 this collection), forming an authorial voice (Morton \& Storch, 2019), managing emotions and time (Straforini, 2015), negotiating the tension between conventionality and innovation (Honan \& Bright, 20r6; Weatherall, 20I9), and making changes to their identity as scholars and writers (Frick \& Brodin, 2020; Mu et al., 2019). The turn to fiction provides a way to confront these issues by creating writing that is humanized and personalized through playful and collaborative engagement as a practice of the exploration of thought.

I see fiction playing an important role in theses as an alternative narrative structure that can represent lived experience, cultural life, complexity, and affect in ways that are often more resonant for readers and that are more accessible to members of the non-academic community. I have suggested thinking about argument in terms of story and exploring data and concepts through characters, scenes, and plots. I also see fiction as an important resource for collaboratively thinking and exploring ideas. There is value in creating spaces where writing can be shared. I have pointed to the potentials of using fiction as a way of thinking differently about theses and the stories they deal with, including stories about the experiences of being a doctoral researcher. In my experience, the creation of "playfulness" in relation to the thesis experience can be hard to foster. The systems of metrics and surveillance used to monitor doctoral students in terms of the quality of their writing and its "doctorateness" as well as how quickly they move through the structured programme of education certainly push against experimentation and play (Aitchison, 2015; Burford, 20I7; Gannon, 2018). And yet, I have found that when students are given the chance to write differently and to think differently, they embrace it.

Ingold (2015) noted that by opening our writing in these kinds of ways, we will perhaps "find that working with words, the writer can once again become a draughtsman or an artist, or even a musician of sorts. We might cease our endless writing about performance, and become performers ourselves" (p. viii). The examples included in this chapter show that such creativity is certainly present in doctoral work and in the academy more broadly. I hope that this chapter can help to further its wider acceptance and development. 


\section{References}

Aitchison, C. (2015). Writing the practice/practise the writing: Writing challenges and pedagogies for creative practice supervisors and researchers. Educational Philosophy and Theory, 47(12), 1291-1303. https://doi.org/10.1080/00131857.2015.1 035629

Alexander, B. K. (2005). Performance ethnography: The reenacting and inciting of culture. The Sage Handbook of Qualitative Research (3rd ed., pp. 411-442). Sage Publications.

Anderson, L. (2006). Analytic autoethnography. Journal of Contemporary Ethnography, 35(4), 373-395. https://doi.org/10.1177/0891241605280449

Augé, M. (2013). No fixed abode: Ethnofiction (C. Turner, Trans.). Seagull Press.

Bahari, A. (2021). Computer-assisted language proficiency assessment tools and strategies. Open Learning: The Journal of Open, Distance and e-Learning, 36(1), 6187. https://doi.org/10.1080/02680513.2020.1726738

Banks, A., \& Banks, S. P. (Eds.). (1998). Fiction and social research: By ice or fire. AltaMira Press.

Burford, J. (2016). Doctoral induction day. In J. Smith, J. Rattray, T. Peseta, \& D. Loads (Eds.), Identity work in the contemporary university: Exploring an uneasy profession (pp. 117-127). SensePublishers.

Burford, J. (2017). Conceptualising doctoral writing as an affective-political practice. International Journal of Doctoral Studies, 12, 17-32. https://doi.org/10.28945/3689

Carey, N. M. (2014). Telling sexual auto-ethnography: (Fictional) stories of the (homo) sexual in social science [Doctoral thesis, Manchester Metropolitan University]. Manchester Metropolitan University e-space. https://e-space.mmu.ac.uk/id/ eprint $/ 336049$

Chase, S. E. (2008). Narrative inquiry: Multiple lenses, approaches, voices. In N. K. Denzin \& Y. S. Lincoln (Eds.), Collecting and interpreting qualitative materials (pp. 57-94). Sage Publications.

Chilton, G., \& Leavy, P. (2014). Arts-based research practice: Merging social research and the creative arts. In P. Leavy (Ed.), The Oxford handbook of qualitative research (pp. 403-422). Oxford University Press. https://doi.org/10.1093/oxford$\mathrm{hb} / 9780199811755.013 .003$

Christensen, J. (2012). Telling stories: Exploring research storytelling as a meaningful approach to knowledge mobilization with Indigenous research collaborators and diverse audiences in community-based participatory research. The Canadian Geographer/Le Géographe Canadien, 56(2), 231-242. https://doi.org/10.1111/j.15410064.2012.00417.x

Clough, P. (2002). Narratives and fictions in educational research. Open University Press. Costley, C. (2013). Evaluation of the current status and knowledge contributions of professional doctorates of professional doctorates. Quality in Higher Education, 19(1), 7-27. https://doi.org/10.1080/13538322.2013.772465

Delgado, R., \& Stefancic, J. (2017). Critical race theory: An introduction (3rd ed.). New York University Press. 
Denzin, N. K., \& Lincoln, Y. S. (2005). Introduction: The discipline and practice of qualitative research. In N. K. Denzin \& Y. S. Lincoln (Eds.), The Sage handbook of qualitative research (3rd ed., pp. 1-32). Sage Publications.

Denzin, N. K., Lincoln, Y. S., \& Smith, L. T. (Eds.). (2008). Handbook of critical and Indigenous methodologies. Sage Publications.

Dirksmeier, P., \& Hellbrecht, I. (2008). Time, non-representational theory and the "performative turn"-Towards a new methodology in qualitative social research. Forum: Qualitative Social Research/Sozialforschung, 9(2). https://doi.org/10.17169/ fqs-9.2.385

Elliott, D. (2014). Truth, shame, complicity, and flirtation: An unconventional, ethnographic (non)fiction. Anthropology and Humanism, 39(2), 145-158. https://doi. org/10.1111/anhu.12052

Elliott, D., \& Culhane, D. (Eds.). (2016). A different kind of ethnography: Imaginative practices and creative methodologies. University of Toronto Press.

Frick, B. L., \& Brodin, E. M. (2020). A return to Wonderland: Exploring the links between academic identity development and creativity during doctoral education. Innovations in Education and Teaching International, 57(2), 209-219. https:// doi.org/10.1080/14703297.2019.1617183

Gannon, S. (2018). On being and becoming the monstrous subject of measurement. In S. Riddle, D. Bright \& E. Honan (Eds.), Writing with Deleuze in the academy: Creating monsters (pp. 73-93). Springer. https://doi.org/10.1007/978-981-132065-1_6

Gerla, J. P. (1995). An uncommon friendship: Ethnographic fiction around finance equity in Texas. Qualitative Inquiry, 1(2), 168-188. https://doi. org/10.1177/107780049500100202

Gibson, W. (2020). Aesthetics, verisimilitude and user engagement: Reporting findings through fictional accounts in qualitative inquiry. Qualitative Research. Advance online publication. https://doi.org/10.1177/1468794120925769

Goodall, H. L., Jr. (2000). Writing the new ethnography. AltaMira Press.

Hallowell, N., Lawton, J., \& Gregory, S. (Eds.). (2004). Reflections on research: The realities of doing research in the social sciences. McGraw-Hill Education.

Herman, C. (2010). Emotions and being a doctoral student. In P. Thomson \& M. Walker (Eds.), The Routledge doctoral student's companion: Getting to grips with research in education and the social sciences (pp. 283-293). Routledge.

Honan, E., \& Bright, D. (2016). Writing a thesis differently. International Journal of Qualitative Studies in Education, 29(5), 731-743. https://doi.org/10.1080/09518398 .2016 .1145280

Jackson, A. Y., \& Mazzei, L. A. (2009). Voice in qualitative inquiry: Challenging conventional, interpretive, and critical conceptions in qualitative research. Routledge. https://doi.org/10.4324/9780203891889

Kamler, B., \& Thomson, P. (2006). Doctoral writing: Pedagogies for work with literatures. In American Educacational Research Association Annual Meeting (pp. 1-13). San Francisco, CA.

Kamler, B., \& Thomson, P. (2008). The failure of dissertation advice books : Toward 
alternative pedagogies for doctoral writing. Educational Researcher, 37(8), 507-514. https://doi.org/10.3102/0013189X08327390

Kara, H. (2013). It's hard to tell how research feels: Using fiction to enhance academic research and writing. Qualitative Research in Organizations and Management: An International Journal, 8(1), 70-84. https://doi. org/10.1108/17465641311327522

Kiesinger, C. E. (1998). Portrait of an anorexic life. In A. Banks \& S. P. Banks (Eds.), Fiction and social research: By ice or fire (pp. 115-136). AltaMira Press.

Krause, E. L. (2009). Unraveled: A weaver's tale of life gone modern. University of California Press.

Lancione, M. (2017). The ethnographic novel as activist mode of existence: Translating the field with homeless people and beyond. Social and Cultural Geography, 18(7), 994-1015. https://doi.org/10.1080/14649365.2016.1231336

Leeke, P. A. (2020). Fake narratives and critical thought: How creative writing can facilitate critical thinking in an age of fake news and false accounting. New Writing: The International Journal for the Practice and Theory of Creative Writing, 17(2), 199-207. https://doi.org/10.1080/14790726.2019.1586954

Lovat, T., Holbrook, A., \& Bourke, S. (2008). Ways of knowing in doctoral examination: How well is the doctoral regime? Educational Research Review, 3(1), 66-76. https://doi.org/10.1016/j.edurev.2007.06.002

Lykke, N. (Ed.). (2014). Writing academic texts differently: Intersectional feminist methodologies and the playful art of writing. Routledge. https://doi. org/10.4324/9781315818566

Mazzei, L. A., \& Jackson, A. Y. (2012). Complicating voice in a refusal to "let participants speak for themselves." Qualitative Inquiry, 18(9), 745-751. https://doi. org/10.1177/1077800412453017

Morton, J., \& Storch, N. (2019). Developing an authorial voice in $\mathrm{PhD}$ multilingual student writing: The reader's perspective. Journal of Second Language Writing, 43(January 2018), 15-23. https://doi.org/10.1016/j.jslw.2018.02.004

Mu, G. M., Zhang, H., Cheng, W., Fang, Y., Li, S., Wang, X., \& Dooley, K. (2019). Negotiating scholarly identity through an international doctoral workshop: A cosmopolitan approach to doctoral education. Journal of Studies in International Education, 23(1), 139-153. https://doi.org/10.1177/1028315318810840

Müller, M. (2017). Are you happy now? A fictional narrative exploration of educator experiences in higher education during the time of \#FeesMustFall. Education as Change, 21(2), 208-236. https://doi.org/10.17159/1947-9417/2017/1960

Narayan, K. (1999). Ethnography and fiction: Where is the border? Antbropology and Humanism, 24(2), 134-147. https://doi.org/10.1525/ahu.1999.24.2.134

Netolicky, D. (2015). Using literary metaphor and characters as structural and symbolic tools: Creating a layered story world while preserving participant anonymity. Narrative Inquiry, 25(2), 264-282. https://doi.org/10.1075/ni.25.2.04net

Okoronkwo, C. C. (2018). Reflections on women living with HIV/AIDS in contemporary Britain [Doctoral thesis, Manchester Metropolitan University]. Manchester Metropolitan University e-space. https://e-space.mmu.ac.uk/id/eprint/620323 
Pandian, A., \& McLean, S. (Eds.). (2017). Crumpled paper boat: Experiments in ethnographic writing. Duke University Press.

Paré, A. (2019). Re-writing the doctorate: New contexts, identities, and genres. Journal of Second Language Writing, 43, 80-84. https://doi.org/10.1016/j. jslw.2018.08.004

Petersen, E. B. (2007). A day at the office at the University of Borderville: An ethnographic short story. International Journal of Qualitative Studies in Education, 20(2), 173-189. https://doi.org/10.1080/09518390601159693

Plummer, K. (2005). Critical humanism and queer theory: Living with the tensions. In N. K. Denzin \& Y. S. Lincoln (Eds.), The Sage Handbook of Qualitative Research (3rd ed., pp. 357-373). Sage Publications.

Richardson, L., \& St. Pierre, E. A. (2005). Writing: A Method of Inquiry. In N. K. Denzin \& Y. S. Lincoln (Eds.), The Sage handbook of qualitative research (3rd ed., pp. 959-978). Sage Publications.

Richardson, M. J. (2015). Theatre as safe space? Performing intergenerational narratives with men of Irish descent. Social and Cultural Geography, 16(6), 615-633. https://doi.org/10.1080/14649365.2014.998269

Rinehart, R. (1998). Fictional methods in ethnography: Believability, specks of glass, and Chekhov. Qualitative Inquiry, 4(2), 200-224. https://doi. org/10.1177/107780049800400204

Russell-Pinson, L., \& Harris, M. L. (2019). Anguish and anxiety, stress and strain: Attending to writers' stress in the dissertation process. Journal of Second Language Writing, 43, 63-71. https://doi.org/10.1016/j.jslw.2017.11.005

Sparkes, A. C. (2002). Fictional representations: On differences, choices and risk. Sociology of Sport Journal, 19(1), 1-24. https://doi.org/10.1123/ssj.19.1.1

St. Pierre, E. A. (2018). Writing post qualitative inquiry. Qualitative Inquiry, 24(9), 603-608. https://doi.org/10.1177/1077800417734567

Straforini, C. M. (2015). Dissertation as life chapter: Managing emotions, relationships, and time. Journal of College Student Psychotherapy, 29(4), 296-313. https:// doi.org/10.1080/87568225.2015.1074021

Thurlow, S., Morton, J., \& Choi, J. (2019). You can't be Shakespearean talking about the institutionalisation of sex offenders: Creativity and creative practices of multilingual doctoral writers. Journal of Second Language Writing, 43, 46-56. https:// doi.org/10.1016/j.jslw.2017.11.002

van Manen, M. (1990). Researching lived experience: Human science for an action sensitive pedagogy. The Althouse Press.

Vannini, P. (Ed.). (2015). Non-representational methodologies: Re-envisioning research. Routledge. https://doi.org/10.4324/9781315883540

Warren, P. P. (2018). Black British and Black Caribbean women's trajectories through the wildernesses of subordinated spaces, (NHS workplace) and unfamiliar places (bigher education): An autoethnography [Doctoral thesis, Birmingham City University]. BCU Open Access Repository. http://www.open-access.bcu.ac.uk/id/eprint/7232

Weatherall, R. (2019). Writing the doctoral thesis differently. Management Learning, 50(1), 100-113. https://doi.org/10.1177/1350507618799867 
Gibson

Weiland, K. M. (2016). Creating character arcs: The masterful author's guide to uniting story structure, plot, and character development (Smashwords ed.). PenForASword Publishing. https://www.smashwords.com/extreader/read/701947/1/creating-character-arcs-the-masterful-authors-guide-to-uniti 


\title{
13 The Curious Predicament of an (un)Comfortable Thesis Conclusion: Writing with New Materialisms
}

\author{
Toni Ingram \\ Auckland University of Technology
}

Abstract: A conclusion often entails providing answers derived from questions like "What does all this mean?" and "What do we now know about the topic we did not know before?" While conventionally appealing, these questions become redundant within a feminist new materialist approach, as they are premised on a separation between the knower (researcher) and the known (subject/s). This chapter explores tensions that emerge between ontological foundations of research and thesis writing conventions, such as a tidy conclusion. Drawing on Karen Barad's (2007) concepts of onto-epistem-ology and intra-action, I consider how a new materialist ontology reconfigures binary concepts such as question/answer, research/ researcher, and knowing/not knowing. These binary concepts often underpin the conclusions a thesis offers, along with doctoral framings of success and failure. The chapter ponders questions that emerge for re-imagining doctoral writing when binaries are blurred.

A conventional Ph.D. thesis ${ }^{1}$ suggests a tidy package neatly bound by an inviting introduction and a comfortable conclusion. This structure follows the guidance provided in the plethora of books on "how to write a thesis": well-meaning advice underpinned by the goal of (ideally) leaving the writer and examiner with a sense of purpose and satisfaction (Eco, 2015; Evans et al., 20I4; Gruba \& Zobel, 20I7; Murray, 20II). In this chapter, I consider what happens when a theoretical framework provides, or rather demands, an ending that is not so neatly packaged. What happens when academic con-

1 The term "thesis" is commonly used in Aotearoa New Zealand, although for some readers, the term "dissertation" may be more familiar. 
ventions rub uneasily with the ontological foundations of the research? And, what (dis)comforts might this afford the doctoral writer?

The discussion draws on my own doctoral experience working with postqualitative research practices (MacLure, 2013a; Mazzei, 2013) and feminist new materialist thought, in particular the work of feminist philosopher and quantum physicist Karen Barad (2003; 2007). Methodologically, postqualitative approaches provide intriguing quandaries for the researcher: What counts as data? What is our relation to it? What is possible to know? (MacLure, 20I3b; St. Pierre, 20I3a). In the context of my research, a feminist new materialist framework demanded a fundamental shift in the analytical approach to data, forcing me to be aware of tendencies to slip into a representational reading (MacLure, 2013a) and the seductive allure of telling a cohesive and linear narrative (Jackson \& Mazzei, 20I2). It raised pertinent questions in regards to the Ph.D. thesis process and expectations of academic conformity and linearity. One point of perplexity was how to write a concluding chapter that was congruent with the theoretical foundations of the research and met doctoral examiner expectations. In what follows, I explore how doctoral writing, in particular a thesis conclusion, often coheres around binary concepts such as question/answer, research/researcher, knowing/not knowing, and failure/success. I consider how Barad's (2007) concepts of onto-epistem-ology and intra-action reconfigure binary concepts and the questions this may raise for re-imagining doctoral writing.

\section{The Journey and the Clot}

Advice books for doctoral researchers often liken the writing of a thesis to a journey: a metaphor that depicts a progression from one fixed point to another (Kamler \& Thomson, 2008). This framing positions doctoral writing as a set of linear steps with a clear start and ending: the thesis conclusion situated at the latter end of the journey signposting "the destination." A concluding chapter is often expected to bring a "sense of closure" and highlight key findings and contributions to knowledge (Evans et al., 20I4, p. I23). In the advice book How to Write a Thesis, for instance, Rowena Murray (20II) posits closure as one of the "ultimate goals of a thesis" (p. 202). In exploring what closure is and how to go about it, Murray (20II) draws on the metaphor of a blood clot:

The blood circulates freely through the system until it meets a clot. The blood may have been thickening for some time, restricting flow, but the clot stops flow completely. Similarly, in the thesis process ideas flow freely and even the writing 
can usefully be free of structure at many stages. However, there is a need to block the free flow and design an endpoint to the thesis. (p. 202)

The blood clot is an intriguing metaphor which Murray (20II) notes brings "appropriate undertones of pressure, tension, pain and anxiety" (p. 202). And, might I suggest, in unfortunate cases, death. As a noun, a (blood) clot can be defined as "a coagulated mass" (Merriam-Webster, n.d.). In the context of writing, a clot signals a sense of completion in the form of "limiting, shutting off, confining" (Murray, 20II, p. 202). Key questions are revisited and answers reinforced; the contribution or success of the thesis is made evident.

This leads me to the question: If a conclusion is the clot, then what does this make the doctoral writer? A clotting agent? Moreover, what does this do to the doctoral writer? Doctoral writing is argued to be both text work and identity work, where the thesis and doctoral identity "are formed together, in and through writing" (Kamler \& Thomson, 2008, p. 508). The writer of a thesis is often positioned as a learner-a research apprentice (Honan \& Bright, 20I6), a positioning clearly evident in the perceived market and ongoing comissioning of "how to write a thesis" texts. As doctoral students, we learn what knowledge is valued, what questions are to be asked and answered (Badenhorst \& Guerin, 20I6). Importantly, we learn how to construct a text that is recognisable within the academic discursive context as a thesis (Honan \& Bright, 20I6). These firmly sedimented ideas may fit cohesively within some disciplines and theoretical approaches; yet for others, they may provoke a sense of unease or discordance for the doctoral writer.

Ideas that constitute a recognisable thesis often cohere around firmly sedimented binary concepts, such question/answer, research/researcher, and knowing/not knowing. Murray (20II) suggests bringing a sense of conclusion to a thesis may entail "limiting the topics in some way, ... filtering out the ideas that you are not going to develop in your thesis" (p. 205). The act of filtering out underdeveloped, or perhaps unanswered, ideas reaffirms a question and answer binary. As the researcher, I am positioned as the one asking and ultimately answering the thesis question/s. Failing to answer a question (or leaving an idea underdeveloped) puts the research/er at risk of not knowing. This is a precarious position premised on a clear separation between the researcher (knower) and research (known).

Many doctoral students have utilized guide books (myself included) and continue to do so. I am not suggesting these texts are unhelpful; however, it is pertinent to ask how this well-intended advice might constrain our questions (and answers) or stifle creativity and freedom (Honan \& Bright, 20I6). How 
might these expectations (re)produce ideas of doctoral success or failure? Questioning the pedagogical and political implications of such advice, Barbara Kamler and Pat Thomson (2008) argue these texts offer a rigid model that follows a prescribed format and style; as a result, academic writing is treated as "a discrete set of technical skills that are effectively context free" (p. 506). There is an underpinning assumption that doctoral writing is a generic and straightforward skill that can be learned (Badenhorst \& Guerin, 2016; Burford, 20I7a) and ultimately conformed to. Although, as Doreen Starke-Meyerring (20II) suggests, research writing is situated rather than universal. In order for research to be recognisable by our peers, as doctoral researchers we must demonstrate that we "know how to play the game according to the particular rules of their discipline" (Badenhorst \& Guerin, 20I6, p. 17).

Playing the game is another familiar metaphor associated with the neoliberal university; in particular, that of the finite games where rules must be followed in order to win (Harré et al., 2017): winning, in this instance, is successfully meeting the criteria to be awarded a doctoral degree. As opposed to the infinite game which encourages diversity and open-ended expression, finite games tend towards sameness, where changing or breaking the rules is considered a violation (Harré, 20I8). Taking into account the rules and structures that surround the doctoral research process, it can easily be understood as a finite game, where the prize (i.e., the award of the Ph.D. degree) enables winners to "claim knowledge of the world which may be treated as the truth" (Harré, 20I8, p. 8). Indeed, as Niki Harré and co-authors (20I7) point out, research is the "most prestigious finite game played by and at universities"; yet, research is also at the center of our academic identities and thus "richly interweaves infinite and finite play" (p. Io). By this, the authors refer to the appearance of playing both games at once: a successful academic activist and a successful researcher. For a doctoral researcher, this may involve the infinite game spaces of open-endedness and creativity (encouraged by a theoretical approach) alongside the academic regulations, expectations, and vulnerability that form the examination process (and finite game). How might we play the game in the spaces in-between?

Umberto Eco (2015), in another advice book also titled How to Write a Thesis, suggests if you "write your thesis with gusto . . you will experience the thesis as a game, as a bet, or as a treasure hunt" (p. 22I). This idea conveys a sense of fun and adventure, which incidentally, are words I would not typically use to describe my own doctoral process. Eco (2015) declares: "You must experience the thesis as a challenge. You are the challenger" (p . 22I). Albeit optimistic and perhaps a little romantic, the sense of "gusto" is not unappealing. This leads me to another question for the doctoral writer, particularly for 
the postqualitative or feminist new materialist variety, such as myself: How do we create a sense of closure- a coagulated mass - without succumbing to the immanent risk of (scholarly) death? Perhaps a bit melodramatic, I blame the metaphoric undertones of pain and anxiety the clot provides. Scholarly death, in my mind, is when an approach (i.e., writing a tidy conclusion with neatly packaged answers) is antithetical to the theoretical foundations of the thesis, thus breaching the rules of the game. Or, in a more positive frame, how do we bring a sense of "gusto," or, more importantly, ourselves as "the challenger" (Eco, 2015, p. 22I $)$, to the game? Or more specifically, to the spaces in-between?

\section{How Does Knowing Matter?}

The concept of knowing is integral to the writing or becoming of a thesis text and the conclusion it may offer. The development of postqualitative inquiry brings a challenge to "conventional, reductionist" modes of qualitative inquiry (St. Pierre, 20II, p. 613) and a rejection of representational thinking (MacLure, 20I3a). Representationalism is premised on "the presumed capacity of the researcher to represent with words the reality s/he observes" (Davies, 20I8, p. II5). Postqualitative inquiry brings a rethinking of how knowledge is produced and what is possible to know (Lather \& St. Pierre, 2013). In relation to my doctoral research, this produced an interesting quandary for me when it came to the thesis conclusion. A conclusion often entails answers derived from questions like "What does all this mean?" and "What do we now know about the topic we did not know before?" While conventionally appealing, these questions become redundant within a new materialist onto-epistem-ology (Barad, 2007), as they are premised on a separation between the knower (researcher) and the known (subject/s) (Allen, 2or8a). Indeed, as I write this chapter, I am speaking from an anthropocentric position, which is somewhat ironic considering the posthumanist framing of my research. I am mindful to note, the use of the researcher "I" in this chapter does not signal an ontologically separate researcher. Rather, it is an entangled "I", denoting the entangled state of the researcher in the research process, by which myself as researcher is also constituted.

Barad (2003; 2007) uses the term onto-epistem-ology to recognise the interdependent and intertwined relationship between being (ontology) and knowing (epistemology). The separation of epistemology from ontology establishes an inherent difference between human and nonhuman, matter and discourse, subject and object. Instead, Barad (2007) argues, the practices of knowing and being cannot be separated from one another and are mutually implicated; as such, onto-epistem-ology can be understood as "the study of 
practices of knowing in being" (p. 185). In Barad's (2003) words, "we do not obtain knowledge by standing outside of the world; we know because we are of the world" (p. 829). In this framing, our ways of being in the world depend on our knowing of it, and our knowing depends on our being (and continuous becoming) in the world (Lenz Taguchi, 20Io). Here, our meaning making is dependent on the material world around us; we are not separate to the world but part of it in a process of mutual and intra-dependent becoming.

Barad's (2007) agential realist framework posits knowing and being as occurring in the same moment; therefore, there is no ontological distance between the researcher and the research subject. As the researcher, I am entangled in the becoming of the research. I cannot stand back, look upon the data, and give meaning to it: This is something a traditional representational account might offer, yet is impossible within a feminist new materialist approach. What counts as method and data take on a different form in new materialist research (Lather \& St. Pierre, 20I3). In conventional qualitative approaches, data is often treated as passive matter waiting to be selected, organized, and interpreted by an ontologically separate researcher (Lenz Taguchi, 20I2; MacLure, 20I3a). In contrast, a new materialist ontology posits data as neither passive nor separate from the researcher. Data and researcher are understood as entangled, acting upon one another in particular ways. A reciprocal, co-constitutive relationship exists between data and researcher, where neither are pre-existing or privileged over the other. Within this non-hierarchical relationship, it is impossible for a researcher to determine what data might mean or represent.

Representational logic assumes there is a primary reality out there to be found and that it can be accurately represented through language (St. Pierre, $20{ }_{3} \mathrm{~b}$ ); both of these notions are untenable within new materialist thought. In contrast to representational approaches, "materialist ontologies prefer a flattened logic (DeLanda, 2002; Hultman \& Lenz Taguchi, 20IO) where discourse and matter are mutually implicated in the unfolding emergence of the world" (MacLure, 2013a, p. 659). Language no longer holds an elevated position of giving meaning to the world; instead, language is one element within an array of entangled forces and intensities. As such, data are not a reflection of reality. Rather, data enacts becomings produced via assembled material-discursive relations. For Barad (2007), the relation between knowledge and being is understood as a profoundly ethical issue. As Bronwyn Davies (2018) explains: "It is a matter of questioning what is being made to matter and how that mattering affects what it is possible to do and think" (p. I2I).

The ontological reorientation of knowing and being reconfigures how we conceptualise endings and the new. This has important implications for what a 
thesis conclusion can say'and do. Within a new materialist framework, Louisa Allen (2018b) succinctly notes "failure to end is an onto-epistemological inevitability" (p. I25), and it is this open-ended potential that forms part of the new that a feminist new materialist approach opens up. For Barad (2007), "the 'new' is the trace of what is yet to become" (p. 383). This "newness" is not nameable or representable because feminist new materialism renders it indeterminate; instead, we might think of the newness as creating "a space where something new can emerge" (Allen, 20I6, p. 8). Perhaps a space of the infinite game?

Feminist new materialisms demand a different logic and attitude towards knowledge and meaning-making. What is required is "a logic of unknowability, a logic of openness and a logic of uncertainty" (Blaise \& Pacini-Ketchabaw, 20I9, p. II7). This unending and unknown potential may sit uncomfortably with some readers and with the conventional expectations of a conclusion, particularly within the context of a doctoral thesis which must endure the rigours of the examination process. In the case of the university where I studied (and other institutions), in order for a Ph.D. degree to be awarded, it must satisfy a range of criteria, including offering "an original contribution to knowledge or understanding in its field" (The University of Auckland, 20I6, p. I). However, what does an "original contribution to knowledge" look like and feel like? More specifically, what understandings of ontology and epistemology is this knowing based on? And, what is at risk if we fail to know?

In her work on reconceptualising qualitative research, Mirka Koro-Ljungberg (2015) raises several pertinent questions: "Why does knowing matter? How does knowing matter? Why does not-knowing appear so scary, inaccessible, distant, and potentially not respected?" (p. Iog). Considering the latter question, Allen (2018b) suggests "knowing" and "being knowledgeable" are "identities humans and social institutions like universities have a deep investment in" (p. I28). Indeed, "knowing" can be understood as the core business of academics and universities; it is part of the structure of the finite game, particularly for winners. Therefore, being open to the unknown "engenders vulnerability as an academic. It risks academic work slipping into unintelligibility and subsequently intellectual obscurity" (Allen, 2018b, p. 5). For the doctoral researcher, the risk of vulnerability can be in the form of failing the Ph.D. examination process or not having sufficient answers to even proceed to examination.

Returning to the idea of closure in How to Write a Thesis, Murray (20II) suggests "closure is invention; the writer has to create it" (p. 203). This idea is appealing. Although, Murray acknowledges for many writers, there is a tension between closure and creativity, as closure encapsulates the idea and practice of limiting and shutting down, hence the metaphor of the clot. This 
tension between closure and creativity extends to the wider university setting. Despite the rhetoric of creativity that many universities espouse, organisational structures, policies, and dominant academic discourses can work to diminish and discourage creativity (Badenhorst \& Guerin, 20I6; Tierney, 20I2). It is also pertinent to note that various disciplines may encourage or regulate creativity (in the form of thesis structure) to varying extents (see Molinari, Chapter 2, this collection). While the rules of the game may differ within and between disciplines, they are ultimately bound within broader university structures and the potential tensions this might produce.

So, where does this leave the doctoral researcher? In relation to doctoral writing, Eileen Honan and David Bright (2016) challenge the normalisation of the thesis structure and call for a "stretching of boundaries" and "interference" with ways of knowing and writing that traditionally comprise qualitative research (p. 735). They argue it is "imperative for doctoral students not to adapt their thinking and writing to what is required": rather, how might we embrace "a style and structure that eschews the already thought; a writing that is against style and against structure” (Honan \& Bright, 2016, p. 733). Perhaps this may include "stretching the boundaries" of what is considered closure and a neatly packaged thesis? Or perhaps blurring the boundaries between knowing and not knowing? What if a thesis had no conclusion? Or the conclusion consisted of two paragraphs? What if the answers a conclusion offers is in the form of further questions?

\section{Success orfand Failure}

So far, this chapter has considered some of the binary concepts that cohere around doctoral research, including question/answer, research/researcher, and knowing/not knowing. Together, these concepts are entangled with another binary: understandings of doctoral success and failure. Failure is often constructed as the opposite of success. What separates success from failure in doctoral research is consistent across many universities: "The work must: constitute an original contribution to knowledge; be scholarly, coherent and rigorous; be appropriately located in terms of the existing scholarly literature and creative work; be well presented; and, demonstrate a synthesis between the creative and critical elements" (Brien et al., 2013, p. 7). The success/failure dichotomy confines doctoral researchers to familiar structures that regulate the possibilities for thinking, doing, and being. Doctoral failure is often seen as something to be avoided or simply "not an option" (Brien et al., 2013, p. 4). Failure, or even the mere threat of failure, induces feelings of anxiety, guilt, and shame. Yet as James Burford (2017b) argues, failure can be a productive 
ground for alternate affects, such as joy, relief, and satisfaction. Offering a queer reading of failure, Burford (20I7b) suggests if we conceptualise doctoral failure as a legitimate position to inhabit, then "we might discern its possibilities for discontent, critique, and rejection of arguably hollow meanings of 'success"' (p. 475). This approach highlights the productive potential of failure in opening possibilities of non-normative becoming (Halberstam, 20II). It also blurs the boundaries between success and failure, prompting us to rethink what is valued and considered productive.

The generative potential to dissolve binaries resonates with new materialist thought; for instance, there is no longer a clear separation between matter/ discourse and subject/object (Dolphijn \& van der Tuin, 20I2). As explained, the concept of onto-epistem-ology (Barad, 2007) dismantles a separation between researcher and research. The capacity to blur boundaries might also be applied to the dichotomy of success and failure. Within a new materialist framework, Anna Hickey-Moody (2019) suggests success and failure can be understood as "intricately enmeshed: one is co-constitutive of the other"; here, the failure/success binary is dissolved as "the constitution of failure relies on the co-constitution of success" (Theories section, para. 2). We can think about this idea through Barad's (2007) notion of intra-action, a key concept in her agential realist framework. Barad (2007) defines intra-action as "the mutual constitution of entangled agencies" (p.33). This means individual agencies are not distinct or prior but rather emerge through their intra-action or mutual entanglement. The concept differs from the idea of interaction, which is premised on an understanding of separate individual entities that exist prior to their interaction or connection.

The ontological reorientation offered by the concept of intra-action opens up a way of approaching the success/failure binary differently. One is not prior or separate to the other; they only become distinct in relation to their mutual entanglement (Barad, 2007). Hickey-Moody (2019) argues acknowledgement of the constitutive relationship between success and failure is needed in how we think about empirical research design and practice. Drawing on her own research practice, Hickey-Moody (2019) suggests failure creates "unexpected successes" (Theories section, para. 2). In doing so, failure in empirical research can be re-thought as dynamic and generative as opposed to a sense of lacking or something to be avoided. This resonates with Koro-Ljungberg's (2015) idea of "productive failures" (p. IOI), which she explores in relation to conclusions and endings. In failing to write a conclusion, Koro-Ljungberg (2015) states: "I also fail to provide you (my readers) a way out, a reason to stop reading, interacting and thinking. Instead I hope that this failure will be a productive new beginning and thus in itself quite desirable" (p. Ior). 
Working with this idea in a new materialist frame, Allen (2018b) conceptualises failure to end a project or book as "a potential that promises further possibility" (p. I29). Failure, in this sense, is seen as productive and generative (Hickey-Moody, 2019); it "indicates that more has to and can be done” (Koro-Ljungberg, 2015, p. IoI). A new materialist framing challenges the oppositional relationship between failure and knowing. Drawing on Chris Hay's (2016, p. 77) idea that "failure can be understood as a way of knowing, and is constitutive of knowledge in its own right," Hickey-Moody (2019) conceptualises failure as "epistemologically specific and valuable because it is epistemologically specific" (Theories section, para. 13). What failure is, and can be, varies across disciplines. This framing is not an attempt to valorise failure (O'Gorman \& Werry, 20I2) nor situate it as a pit stop or stepping stone on the trajectory to success. Rather, it is an attempt to think differently about success and failure, shifting it from an either/or positioning to one of mutual entailment.

Within a new materialist framing, success and failure emerge in material-discursive entanglements. This means failure and success are no longer solely in my domain as an individual entity (i.e., doctoral researcher). What might this space mean for the doctoral researcher? What possibilities might it open up for re-imagining doctoral writing? Patti Lather and Elizabeth St. Pierre (2013) make an interesting suggestion: "At some point, we have to ask whether we have become so attached to our invention-qualitative research-that we have come to think it is real" (p. 63I). They note "the ethical charge of our work as inquirers is surely to question our attachments that keep us from thinking and living differently" (Lather \& St. Pierre, 2013, p. 63I). With this in mind, perhaps we need to question our attachments to meanings of success and failure, to knowing and to tidy conclusions? Perhaps we need to challenge the desire or expectation to justify ourselves as winners in the Ph.D. finite game? As Harré and co-authors (2017) suggest, in order to play the infinite game, we need to "cultivate indifference to convention"; we need to recognise the university's finite games, such as the doctoral thesis, "for what they are, devices that can and must be played with, in an effort to bring alive the infinite spaces that lie between" (pp.7-8). If, as Murray (20II) suggests, "closure is invention" (p. 203), what could writing a thesis look like or feel like in this infinite space?

My own curious predicament of writing an (un)comfortable conclusion was an entanglement of theory, ideas, feelings, and academic requirements. It was a curious space of impending relief, unease, tentative indifference, and conformity. It was a balancing act fuelled by questions: What is possible to know and say within this theoretical frame? Will this satisfy the examiners? 
Will the examiners be appropriate? For me, the thesis conclusion was a manifestation of this balancing act. In a traditional sense, it did (some of) the work of a concluding chapter by bringing together key ideas and arguments. At the same time, in keeping with the study's ontological foundations, the chapter was by no means an ending in a finite sense-it was both a conclusion and an opening to new possibilities and new questions. Integral to these new possibilities was a shift in how I came to understand my role as researcher and my relationship with the research. Looking back, it was a fruitful space for me as a doctoral researcher-an invitation to becoming comfortable with feeling uncomfortable. In order to "bring alive these infinite spaces" (Harré et al., 20I7, pp. 7-8), maybe we need to question our notions of who writes whom? As Barad (2007) would suggest: is it that I have written this thesis, or has it written me? Perhaps, “we' have 'intra-actively' written each other" (p. $\mathrm{x})$. The practice of writing a thesis is a "mutually constitutive working out, and reworking, of" both thesis and ourselves as researcher (Barad, 2007, p.x). Who we are as doctoral researchers is produced in the entanglements. What spaces do we want these to be?

\section{References}

Allen, L. (2016). Photos of (no)thing: The becoming of data about sexuality at school. Reconceptualising Educational Research Methodology, 7(1). https://doi. org/10.7577/rerm.1822

Allen, L. (2018a). Sexual choreographies of the classroom: Movement in sexuality education. Discourse: Studies in the Cultural Politics of Education, 39(3), 347-360. https://doi.org/10.1080/01596306.2016.1263184

Allen, L. (2018b). Sexuality education and new materialism: Queer things. Palgrave Macmillan. https://doi.org/10.1057/978-1-349-95300-4

Badenhorst, C., \& Guerin, C. (Eds.). (2016). Research literacies and writing pedagogies for masters and doctoral writers. Brill.

Barad, K. (2003). Posthumanist performativity: Toward an understanding of how matter comes to matter. Signs: Journal of Women in Culture and Society, 28(3), 801-831. https://doi.org/10.1086/345321

Barad, K. (2007). Meeting the universe halfway: Quantum physics and the entanglement of matter and meaning. Duke University Press.

Blaise, M., \& Pacini-Ketchabaw, V. (2019). Enacting feminist movement pedagogies in the early years. In J. Osgood, \& K. H. Robinson (Eds.), Feminists researching gendered childhoods: Generative entanglements (pp.109-120). Bloomsbury Academic.

Brien, D. L., Burr, S., \& Webb, J. (2013). 'Fail better': Doctoral examination and the creative field. Text, Special Issue 22,1-12. http://www.textjournal.com.au/speciss/ issue22/Brien\&Burr\&Webb.pdf 
Ingram

Burford, J. (2017a). Conceptualising doctoral writing as an affective-political practice. International Journal of Doctoral Studies, 12, 17-32. https://doi. org/10.28945/3689

Burford, J. (2017b). Not writing, and giving 'zero-f**ks' about it: Queer(y)ing doctoral 'failure.' Discourse: Studies in the Cultural Politics of Education, 38(4), 473-484. https://doi.org//10.1080/01596306.2015.1105788

Davies, B. (2018). Ethics and the new materialism: A brief genealogy of the 'post' philosophies in the social sciences. Discourse: Studies in the Cultural Politics of Education, 39(1), 113-127. https://doi.org/10.1080/01596306.2016.1234682

DeLanda, M. (2002). Intensive science and virtual philosophy. Continuum.

Dolphijn, R., \& van der Tuin, I. (2012). New materialism: Interviews E cartographies. Open Humanities Press. http://hdl.handle.net/2027/spo.11515701.0001.001

Eco, U. (2015). How to write a thesis (C. Farina \& G. Farina, Trans.). MIT Press.

Evans, D., Gruba, P., \& Zobel, J. (2014). How to write a better thesis (3rd ed.). Springer. https://doi.org/10.1007/978-3-319-04286-2

Gruba, P., \& Zobel, J. (2017). How to write your first thesis. Springer. https://doi. org/10.1007/978-3-319-61854-8

Halberstam, J. (2011). The queer art of failure. Duke University Press.

Harré, N. (2018). The infinite game: How to live well together. Auckland University Press.

Harré, N., Grant, B. M., Locke, K., \& Sturm, S. (2017). The university as an infinite game: Revitalising activism in the academy. Australian Universities' Review, 59(2), 5-13.

Hay, C. (2016). Knowledge, creativity and failure: A new pedagogical framework for creative arts. Palgrave Macmillan.

Hickey-Moody, A. (2019). Three ways of knowing failure. MAI Feminism E̋ Visual Culture, 4. https://maifeminism.com/three-ways-of-knowing-failure/

Honan, E., \& Bright, D. (2016). Writing a thesis differently. International Journal of Qualitative Studies in Education, 29(5), 731-743. https://doi.org/10.1080/0951839 8.2016.1145280

Hultman, K., \& Lenz Taguchi, H. (2010). Challenging anthropocentric analysis of visual data: A relational materialist methodological approach to educational research. International Journal of Qualitative Studies in Education, 23(5), 525-542. https://doi.org/10.1080/09518398.2010.500628

Jackson, A. Y., \& Mazzei, L. A. (2012). Thinking with theory in qualitative research: Viewing data across multiple perspectives. Routledge. https://doi. org/10.4324/9780203148037

Kamler, B., \& Thomson, P. (2008). The failure of dissertation advice books: Toward alternative pedagogies for doctoral writing. Educational Researcher, 37(8), 507514. https://doi.org/10.3102/0013189X08327390

Koro-Ljungberg, M. (2015). Reconceptualizing qualitative research: Methodologies without methodology. Sage.

Lather, P., \& St. Pierre, E. A. (2013). Post-qualitative research. International Journal of Qualitative Studies in Education, 26(6), 629-633. https://doi.org/10.1080/09518 398.2013.788752 
Lenz Taguchi, H. (2010). Going beyond the theory/practice divide in early childhood education: Introducing an intra-active pedagogy. Routledge.

Lenz Taguchi, H. (2012). A diffractive and Deleuzian approach to analysing interview data. Feminist Theory, 13(3), 265-281.

MacLure, M. (2013a). Researching without representation? Language and materiality in post-qualitative methodology. International Journal of Qualitative Studies in Education, 26(6), 658-667. https://doi.org/10.1080/09518398.2013.788755

MacLure, M. (2013b). The wonder of data. Cultural Studies-Critical Methodologies, 13(4), 228-232. https://doi.org/10.1177/1532708613487863

Mazzei, L. A. (2013). A voice without organs: Interviewing in posthuman research. International Journal of Qualitative Studies in Education, 26(6), 732-740. https:// doi.org/10.1080/09518398.2013.788761

Merriam-Webster. (n.d). Clot. In Merriam-Webster.com dictionary. Retrieved May 12, 2020, from https://www.merriam-webster.com/dictionary/clot

Murray, R. (2011). How to write a thesis (3rd ed.). Open University Press.

O'Gorman, R., \& Werry, M. (2012). On failure (on pedagogy): Editorial introduction. Performance Research, 17(1), 1-8. https://doi.org/10.1080/13528165.2012.651 857

St. Pierre, E. A. (2011). Post qualitative research: The critique and the coming after. In N. K. Denzin, \& Y. S. Lincoln (Eds.), The SAGE handbook of qualitative research (4th ed., pp. 611-625). Sage.

St. Pierre, E. A. (2013a). The appearance of data. Cultural Studies-Critical Methodologies, 13(4), 223-227. https://doi.org/10.1177/1532708613487862

St. Pierre, E. A. (2013b). The posts continue: Becoming. International Journal of Qualitative Studies in Education, 26(6), 646-657. https://doi.org/10.1080/0951839 8.2013.788754

Starke-Meyerring, D. (2011). The paradox of writing in doctoral education: Student experiences. In L. McAlpine \& C. Amundsen (Eds.), Doctoral education: Research-based strategies for doctoral students, supervisors and administrators (pp. 75-95). Springer. https://doi.org/10.1007/978-94-007-0507-4_5

The University of Auckland. (2016). Statute and guidelines for the degree of Doctor of Philosophy (PhD). https://cdn.auckland.ac.nz/assets/policyhub/2016\%20Statute\%20website\%20version.pdf

Tierney, W. G. (2012). Creativity and organizational structure. In M. N. Bastedo (Ed.), The organization of higher education (pp. 160-180). The Johns Hopkins University Press. 



\title{
Conclusion: The Unfinished Business of Re-imagining Doctoral Writing
}

\author{
James Burford \\ La Trobe University \\ Brittany Amell \\ Carleton University \\ Cecile Badenhorst \\ Memorial University
}

What imaginings of the "doctoral writer" circulate in the talk of doctoral researchers and their supervisors? How do institutional policies and the conventions of particular disciplines shape the ways in which doctoral writing is imagined? Why, and in what ways, has doctoral writing been re-imagined in the twenty-first century? What future imaginings of doctoral writing may be hovering on the horizon? This book has gathered a diverse group of authors to consider these challenging questions. Our goal, as editors, has not been to push toward a pre-determined answer. Instead, we have sought to open up doctoral writing as an area of research that would benefit from more questions asked about what the various players involved understand the future of doctoral writing to be.

Imaginings of doctoral writing and writers are always in flux and under pressure, with calls to conserve and protect some ideas and practices and to reform, innovate, or abandon others. In recent years, questions about how we imagine doctoral writing have arisen to prominence because of significant contextual shifts within doctoral education more broadly. Access to doctoral education has expanded globally (Nerad, 20Io), with increasing enrolments of "non-traditional" doctoral students "who are marginalised by the dominant academic scholarly culture” (Naidoo, 20I5, p. 34I). Doctoral education is also increasingly internationalized (Ryan, 20I2), particularly in the Anglophone Global North, and international students bring with them diverse epistemologies, as well as expectations regarding intellectual work. At the same time, doctoral graduates have become re-positioned as future knowledge workers who have the capacity to advance national innovation and economic growth 
(Cuthbert \& Molla, 2015). As a result, doctoral education is a practice that is increasingly subject to audit and oversight from national and provincial governments, which arguably frame doctoral education in ways that are "increasingly narrow, utilitarian and economistic" (Lee et al., 2009, p. 276). All of these shifts have re-shaped how the doctoral student has been imagined and in turn how doctoral writing and writers may be conceived.

It is in this changing context that doctoral writing has become "increasingly visible as a point of tension" (Aitchison \& Lee, 2006, p. 265). Because the practice of doctoral writing is so fundamental to the production of doctoral research and researchers, it is entangled with broader doctoral education concerns, such as attrition, completion timeliness, the quality of supervision, research impact, research integrity, decolonization, and, finally, the transferability of knowledge and skills to industry settings. It is also important to emphasise that doctoral writing is not an ahistorical practice that takes place in a vacuum, nor is it an arhetorical one (Doody, Chapter 6, this volume). World events, including the COVID-I9 pandemic (which is ongoing as we write this), have added greater urgency to these conversations about what doctoral writing may be and how it might be taught, learned, or materialised.

To date, a body of scholarship has emerged that has sought to experiment with various re-imaginings of doctoral education. For instance, scholars have sought to re-imagine doctoral programs in diverse disciplinary areas (e.g., Prasad, 20I5; Smith, 20I5), the pedagogies and temporal practices of doctoral education (Gravett, 202I), and the ways we narrate doctoral failure (De Santolo, 202I). However, the particular locus for re-imagining that we have sought to engage with in this book has been with regards to doctoral writing. We extend an existing body of scholarship that has also been re-imagining doctoral writing (e.g., Starke-Meyerring, 20I4), as well as tracking such re-imaginings (e.g., Ravelli et al., 20I4). Each of the chapters in this book has emphasised that how we imagine doctoral writing and the idea of the "doctoral writer" matters. As chapter authors have pointed out, how we imagine doctoral writing can constrain, enable, and regulate what is knowable, doable, and possible for writers, as well as the representational forms scholarship can take. Recently, calls to reimagine doctoral writing have intensified (Paré, 20I7, 20I9; Porter et al., 20I8), with particular attention paid to the deconstruction of sedimented imaginings often rooted in Eurocentrism (Battiste, I998; Coburn, 2015, foreword by LaRocque). As Paré (20I7) notes, when it comes to imagining what doctoral writing can be, "many scholars and institutions are struggling to catch up with the times" (p. 4I6). We hope this book has helped readers by offering new pathways into imagining doctoral writing as well as opportunities to consider some of the innovative practices present across these pages. 


\section{Places, Disciplinary Spaces, and Methodologies in this Collection}

As we have outlined in this chapter, doctoral education is a global practice, so any consideration of how doctoral writing may be re-imagined must consider the diverse contexts of many nations around the world. In this collection, we are pleased to have gathered the insights of contributors writing from Oceania, including Aotearoa New Zealand (Mitchell, Chapter I; Fa'avae, Chapter 8; Kelly et al., Chapter ıo; Ingram, Chapter I3) and Australia (Thurlow, Chapter 5; Kelly et al., Chapter Io; Ravelli et al., Chapter II); Asia, including Bangladesh (Naomi, Chapter 9) and Japan (Kelly et al., Chapter Io); Africa, including South Africa (van Schalkwyk \& Jacobs, Chapter 4); Europe, including Denmark (Skov, Chapter 3) and the UK (Molinari, Chapter 2; Gibson, Chapter I2); and North America, including Canada (Doody, Chapter 6) and the US (Cox et al., Chapter 7). Interested readers can dip into particular chapters in order to consider how national policy contexts may shape possible routes for re-imagining doctoral writing. Alternatively, readers can consider the book as a whole in order to compare accounts of doctoral writing across these contexts. One chapter (Kelly et al., Chapter Io) extends beyond national borders to engage a comparative perspective in a way we find innovative. Despite the diversity of the contexts represented in this book, we acknowledge that there is more work to do in order to understand imaginings of doctoral writing and writers in Global South contexts. If doctoral writing researchers are to pursue a globally democratic agenda for knowledge production, further expanding this map remains a necessity.

Doctoral writing is a practice that is inflected with significant disciplinary difference. In this collection we have gathered accounts of doctoral writing within the disciplines of education (Mitchell, Chapter I), the arts (Thurlow, Chapter 5), interdisciplinary life sciences (Doody, Chapter 6), and the visual and performing arts (Ravelli et al., Chapter II), among other broader surveys (e.g., Kelly et al., Chapter Io). The book is also diverse in terms of the data collection methods that authors deployed, ranging from close textual analyses of both historical (Kelly et al., Chapter Io) and contemporary (Ravelli et al., Chapter II) theses, qualitative research with doctoral students or supervisors (Mitchell, Chapter I; Skov, Chapter 3; Thurlow, Chapter 5), autoethnographies (Fa'avae, Chapter 8; Naomi, Chapter 9), and a collaborative autoethnographic reflection (Cox et al., Chapter 7). Many of the chapters have also emerged out of doctoral research projects (e.g., Mitchell, Chapter I; Molinari, Chapter 2; Skov, Chapter 3; Thurlow, Chapter 5), which we suggest is a promising sign for the future of doctoral writing research. 


\section{The Contribution of Re-imagining Doctoral Writing}

Doctoral writing is frequently framed as a monolithic concept. However, across this book, authors have demonstrated that "doctoral writing" takes on multiple meanings and practices, suggesting that we ought to continue to trouble its definition and avoid taking it for granted. Indeed, as Julia Molinari (Chapter 2) argues, doctoral writing may be considered a complex open and emergent social system that is capable of change. The ways in which we imagine doctoral writing practices or texts may need to change for epistemic reasons, as Ravelli and colleagues (Chapter II) argue with regard to theses in the visual and performing arts.

The title of our book includes the word re-imagining with a hyphen quite deliberately. The hyphen between re and imagining is meaningful, acting as a bridge that encourages authors to locate dominant imaginings of doctoral writing at the same time as they may seek to construct new ones. Across this collection, the most significant current imagining we can trace is the idea of the competitive, individualised, and disembodied doctoral writer. This imagining can be seen in both historical theses (e.g., Kelly et al., Chapter io) as well as in the present (e.g., Cox et al., Chapter 7; Skov, Chapter 3). This imagining of the doctoral writer is also connected to neoliberal subjectivities that have been articulated in Catherine Mitchell's chapter (Chapter I). Other dominant imaginings of doctoral writing that we see travel through the collection are images of doctoral writing texts as highly disciplined and normative. Perhaps this should not surprise us, as often, doctoral pedagogues aim to show students what the boundaries are in order to pin down writing and unpack it so that students can accomplish it. Across this book, we see accounts of normative forms (Ravelli, et al., Chapter II), where particular ideas of knowledge and truth are preeminent (Gibson, Chapter I2) and where doctoral knowledge is written in ways that are tidy and conclusive (Ingram, Chapter 13). Another key imaginary that is clear across our collection is one that sees doctoral writing through a colonizing/colonized gaze, where writing norms and conventions associated with the Global North are almost unquestionable (Naomi, Chapter 9).

When it comes to the re-imaginings articulated throughout this book, there is a clear shift away from the idea of the autonomous and individualized author (Lee \& Williams, 1999). Instead, authors offer re-imaginings of doctoral writing that configure it as an embodied, affective, and relational practice (Cox et al., Chapter 7), where the author may be de-centered and reconceived as enmeshed with an assemblage of other beings and objects (Kelly et al., Chapter Io). Not only can doctoral writing pedagogy be expanded beyond 
the individual, doctoral writing pedagogy may be extended beyond notions of supervision dyads or triads via re-imaginings of communal doctoral pedagogy (van Schalkwyk \& Jacobs, Chapter 4; see also Peseta et al., 202I).

Other re-imaginings that are present across the chapters of this collection are decolonial and subaltern imaginings (Fa'aavae, Chapter 8; Naomi, Chapter 9; van Schalkwyk \& Jacobs, Chapter 4), where authors discuss or embody examples of how doctoral writers can draw on different epistemologies and languages. For example, in Naomi's chapter (Chapter 9) we have an example of performative doctoral writing - which includes, perhaps, a reimagining of the "academic voice," one that can be spiritually inflected and located in a context outside of the Global North. Other scholars have offered coalitional social justice re-imaginings that connect doctoral writers to each other and to the communities they serve (Cox et al., Chapter 7). Authors in this collection have re-imagined doctoral writing as including a diversity of texts and multivalent approaches to writing them (Ravelli et al., Chapter II), as consisting of interdisciplinary imaginings (Doody, Chapter 6), as messing with truth and playing with fiction (Gibson, Chapter I2), and as going beyond the closed systems that are often reproduced (Molinari, Chapter 2).

In order to flesh out doctoral writing re-imaginings, the authors across this collection offer new conceptual tools and paths of inquiry to think with, including queer concepts (Thurlow, Chapter 5), feminist concepts (Naomi, Chapter 9), new materialisms (Kelly et al., Chapter io; Ingram, Chapter I3), decolonial approaches (Fa'avae, Chapter 8; Naomi, Chapter 9), genre-based approaches (Doody, Chapter 6), legitimation code theory (Ravelli, et al., Chapter II; van Schalkwyk \& Jacobs, Chapter 4), as well as critical realism and complexity theory (Molinari, Chapter 2). By re-imagining, these chapters move us in a different direction, loosening up the boundaries of doctoral writing and embracing its fluidity. However, it is important to note that this opening up is quite risky — students might encounter consequences and dangers as they try to push beyond recognised boundaries.

\section{Final Thoughts: The Unfinished Business of Re-imagining Doctoral Writing}

In a nutshell, this book has sought to unsettle any attempt to take what we mean by doctoral writing and "the doctoral writer" for granted. Authors have revealed that imaginings of doctoral writing/writers are highly contested, and they have argued that doctoral writing matters, for doctoral students, their supervisors, institutions, and our world. It is our view that continuing to in- 
terrogate the imaginaries of doctoral writing is a vital part of critical education and writing frameworks.

While this book was primarily aimed as a resource for researchers of doctoral writing, we hope the book may be useful for practitioners and students who may find in these pages some pathways forward. If you are a doctoral student who needs a lifeline to help you re-imagine your own thesis, we hope this book has offered resources to assist you to build a case for why and how it may be possible.

As Frances Kelly (20I7) observes:

Writing begins (and happens) in the dark. It involves productive uncertainty-wobbling between the realms of knowing and not-knowing (and back again). It involves excitement, anxiety, risk, oscillation, and a feeling of being impelled forward with a question that might take on several 'new and different forms' over the journey. (p. 40)

This has certainly been our experience as editors of this collection, and we think it is a good thing! We believe this book offers several starting points for future researchers interested, as we are, in studying doctoral writing, and we extend an invitation to those of you who feel called to join us- the authors and editors-wobbling in this "productive uncertainty."

\section{References}

Aitchison, C., \& Lee, A. (2006). Research writing: Problems and pedagogies. Teaching in Higher Education, 11(3), 265-278. https://doi. org/10.1080/13562510600680574

Battiste, M. (1998). Enabling the autumn seed: Toward a decolonized approach to Aboriginal knowledge, language, and education. Canadian Journal of Native Education, 22(1), 16-27.

Coburn, E. (with LaRocque, E.). (2015). More will sing their way to freedom: Indigenous resistance and resurgence. Fernwood Publishing.

Cuthbert, D., \& Molla, T. (2015). The politicization of the $\mathrm{PhD}$ and the employability of doctoral graduates: An Australian case study in a global context. In D. E. Neubauer \& K. Ghazali (Eds.), Technology and workplace skills for the twenty-first century (pp. 95-111). Palgrave Macmillan. https://doi.org/10.1057/9781137491923_8

De Santolo, J. (2021). Reframing failure and the Indigenous doctoral journey. In D. Fam \& M. O'Rourke (Eds.), Interdisciplinary and transdisciplinary failures: Lessons learned from cautionary tales (pp. 149-164). Routledge.

Gravett, K. (2021). Disrupting the doctoral journey: Re-imagining doctoral pedagogies and temporal practices in higher education. Teaching in Higher Education, 26(3), 293-305. https://doi.org/10.1080/13562517.2020.1853694 
Kelly, F. (2017). The idea of the PhD: The doctorate in the twenty-first-century imagination. Routledge.

Lee, A., Brennan, M., \& Green, B. (2009). Re-imagining doctoral education: Professional doctorates and beyond. Higher Education Research E Development, 28(3), 275-87. https://doi.org/10.1080/07294360902839883

Lee, A., \& Williams, C. (1999). Forged in fire: Narratives of trauma in $\mathrm{PhD}$ supervision pedagogy. Southern Review: Communication, Politics \& Culture, 32(1), 6-26.

Naidoo, D. (2015). Understanding non-traditional $\mathrm{PhD}$ students habitus-Implications for $\mathrm{PhD}$ programmes. Teaching in Higher Education, 20(3), 340-351. https:// doi.org/10.1080/13562517.2015.1017457

Nerad, M. (2010). Globalization and the internationalization of graduate education: A macro and micro view. Canadian Journal of Higher Education/La Revue Canadienne d'Enseignement Supérieur, 4O(1),1-12. https://doi.org/10.47678/cjhe.v40i1.1566

Paré, A. (2017). Re-thinking the dissertation and doctoral supervision/Reflexiones sobre la tesis doctoral y su supervisión. Journal for the Study of Education and Development/Infancia y Aprendizaje, 4O(3), 407-428. https://doi.org/10.1080/0210 3702.2017.1341102

Paré, A. (2019). Re-writing the doctorate: New contexts, identities, and genres. Journal of Second Language Writing, 43, 80-84. https://doi.org/10.1016/j.jslw.2018.08.004

Peseta, T., Kligyte, G., Bell, A., Hardiman, B., Leadbetter, D., Pizzica, J., Saliba, G., Salisbury, F., Thomson, K., \& Yucel, R. (2021). Borders, paths and orientations: Assembling the higher education research field as doctoral students and supervisors. Teaching in Higher Education, 26(3), 422-437. https://doi.org/10.1080/13562 517.2021.1885022

Porter, S., Young, L., Aarssen, L., Gibbs, R., Klein, R., Paré, A., Ryoo, A., \& Wood-Adams, P. (2018). Report of the CAGS task force on the dissertation-Purpose, content, structure, assessment. Canadian Association for Graduate Studies. https://cags.ca/wp-content/uploads/2018/09/Dissertation-task-force-report-FINAL-Sept-EN-1.pdf

Prasad, A. (2015). Liminal transgressions, or where should the critical academy go from here? Reimagining the future of doctoral education to engender research sustainability. Critical Perspectives on Accounting, 26, 108-116. https://doi. org/10.1016/j.cpa.2014.09.006

Ravelli, L., Paltridge, B., \& Starfield S. (Eds.) (2014). Doctoral writing in the creative and performing arts. Libri.

Ryan, J. (2012). Internationalisation of doctoral education: Possibilities for new knowledge and understandings. Australian Universities' Review, 54(1), 55-63.

Smith, S. (2015). Manifesto for the bumanities: Transforming doctoral education in good enough times. University of Michigan Press. https://doi.org/10.3998/dcbooks.13607059.0001.001

Starke-Meyerring, D. (2014). Writing groups as critical spaces for engaging normalized institutional cultures of writing in doctoral education. In C. Aitchison \& C. Guerin (Eds.), Writing groups for doctoral education and beyond: Innovations in practice and theory (pp. 65-81). Routledge. 



\section{Contributors}

Brittany Amell is a doctoral candidate at Carleton University in the Department of Applied Linguistics and Discourse Studies. She teaches, mentors, and coaches others on the research, theory, and pedagogy of academic writing. Her Ph.D. research considers the writing that she and other doctoral students do for their degrees and was awarded a Joseph-Armand Bombardier Canada Graduate Scholarship (SSHRC, 20I7-2020). In 20I8, she co-edited with, Cecile Badenhorst, a special issue of Discourse and Writing/Rédactologie titled "Play, Visual Strategies \& Innovative Approaches to Graduate Writing."

Cecile Badenhorst is a Professor in the Adult Education/Post-Secondary program in the Faculty of Education at Memorial University, Newfoundland, Canada. She teaches courses in the post-secondary undergraduate and graduate programs on university teaching and learning, as well as courses in the Faculty's doctoral program. As a researcher, she conducts research and publishes in the areas of doctoral education, doctoral writing, graduate writing, thesis/publication writing pedagogies, academic literacies, and faculty writing. She engages in qualitative, arts-based, and post-structural research methodologies. As a twice-awarded Carnegie African Diaspora Fellow, she has delivered workshops, courses, and mentoring on writing in South Africa. She has a YouTube channel with videos on doctoral and master's research writing.

James Burford is Lecturer in Research Education and Development in the Graduate Research School, La Trobe University, Melbourne, Australia. James is a critical university studies researcher, and he is particularly interested in space, place, affect, and politics in the academic profession and doctoral education. James' doctoral thesis received the 2017 NZARE Sutton-Smith Award. James has taught in the areas of comparative education, educational equity, and academic literacies. His recent projects have focused on academic mobilities (both short and longer term), as well as the spatialities of graduate education. With Emily Henderson, James edits Conference Inference, an academic blog on conferences.

Matthew B. Cox is Associate Professor and Director of Graduate Studies in the Department of English at East Carolina University. His research and teaching connect cultural rhetorics, technical and professional writing studies, and queer rhetoric studies. Recent publications include the collection Re/ Orienting Writing Studies: Queer Methods, Queer Projects (with Caroline Dadas and Will Banks) and work in the Journal of Business and Technical Communication and Present Tense: A Journal of Rhetoric in Society. 
Elise Dixon is Assistant Professor of English and Director of the University Writing Center at the University of North Carolina at Pembroke. As a rhetoric and writing studies scholar who focuses on queer, feminist, and cultural rhetorics, her research explores how people compose together to develop a sense of critical agency. Her work has appeared in the Writing Lab Newsletter, The Peer Review Journal, The Journal of Veteran Studies, and numerous books.

Sara Doody currently teaches writing at the University of British Columbia. Her research broadly explores science writing, knowledge, and identity in higher education. Her most recent study explored the nature of writing in interdisciplinary life sciences doctoral programs and its implications for how doctoral students negotiate knowledge and identity across disciplinary boundaries.

David Taufui Mikato Fa'avae is a Tongan scholar with heritage links to Samoa. He was born and raised in Niue and was educated in Aoteraoa New Zealand. He is the son of Sio Milemoti Fa'avae and Fatai Onevai Fa'avae. David's ancestors were from Ma'ufanga (Tongatapu), 'Eua, Niuafo'ou, Taunga Vava'u, Pukotala i Ha'ano Ha'apai, and Satalo, Upolu in Samoa. David was a secondary school teacher who later worked at the University of the South Pacific (USP) Institute of Education, based at its Tonga campus, from 2016 to 2020. He currently works at Te Whare Wānanga o Waikato (University of Waikato) in Aotearoa.

Will Gibson is Reader in Social Research at the University College London (UCL) Institute of Education. His background is in interactional sociology, particularly symbolic interactionism, ethnomethodology, and conversation analysis. He has conducted empirical research in a wide range of contexts, including education, healthcare, music performance, and online interaction. He has published widely on issues relating to qualitative methodology and on interactionist concepts and theory. As a teacher, Will has worked with doctoral students for over fifteen years. He has delivered courses and seminars in the UK and around the world on aspects of methodology and doctoral study and also has led writing and study retreats. He is currently Director of the Academic Writing Centre at the UCL Institute of Education, leading a team of experts who provide writing support for doctoral students.

Toni Ingram is Senior Lecturer in the School of Education, Auckland University of Technology (AUT), Aotearoa New Zealand. Toni's research is situated in the areas of girlhood, gender, sexualities, and schooling. She is interested in the relationship between schooling practices and the production and regulation of young people's gender and sexualities. Toni's current work is informed by feminist new materialisms, affect theory, and posthumanist methodological approaches. 
Cecilia Jacobs is Associate Professor in Higher Education at the Centre for Health Professions Education at Stellenbosch University. Her field of expertise is higher education studies, and she has worked predominantly in the professionalisation of academics for their teaching roles. Her work has been of a transdisciplinary nature, and she has always conducted research at the intersection of her field and other disciplines, such as engineering and, currently, health sciences. Her current research focuses on the question of knowledge and the importance of its centrality in debates on higher education teaching and learning.

Frances Kelly is Senior Lecturer in Critical Studies in Education at the University of Auckland/Te Whare Wananga O Tamaki Makaurau, Aotearoa New Zealand. Frances' research spans higher education and the history of education, with an abiding interest in doctoral education. She is the author of The Idea of the PhD (Routledge, 20I7). Frances' recent work critically explores material practices and spatialities in educational contexts.

Catherine Manathunga is Professor of Education Research and Co-Director of the Indigenous and Transcultural Research Centre at the University of the Sunshine Coast, Australia. She is an historian with expertise in historical, sociological, and cultural studies research, bringing an innovative perspective to higher education research. Catherine has conducted research projects on doctoral education and academic identities. Her recent books include Intercultural Postgraduate Supervision: Reimagining Time, Place and Knowledge (Routledge, 20I4) and, with Dorothy Bottrell, two co-edited collections titled Resisting Neoliberalism in Higher Education: Vol. I Seeing Through the Cracks and Vol. 2 Prising Open the Cracks (Palgrave Macmillan, 2019).

Katie Manthey is Assistant Professor of English and Writing Center Director at Salem College, a small women's college in Winston Salem, NC. Her research and teaching are focused around professional writing, cultural rhetorics, dress studies, and civic engagement. She is a body positive activist and moderates the website Dress Profesh, which highlights the ways that dress codes are racist, cissexist, ageist, classist, etc. Her work has appeared in Peitho: The Journal of the Coalition of Women Scholars in the History of Rhetoric E Composition, Jezebel, and Computers and Composition.

Catherine Mitchell (Taranaki) currently works as an academic at the Unitec Institute of Technology in Aotearoa/New Zealand. Her research focuses on postgraduate education, especially on the experiences of postgraduate students from diverse backgrounds. Her work also explores issues associated with academic identity development and academic writing. Catherine locates her research within the emerging field of critical university studies. She has recently completed her Ph.D. on first-generation students in doctoral education. 
Julia Molinari is a teacher of English for academic purposes and research writing as well as an independent researcher and blogger. Her work and studies have developed in the Italian and British higher education contexts. Her Ph.D. thesis was supervised at the University of Nottingham, UK, by Professor Patricia Thomson (School of Education) and Professor Andrew Fisher (Department of Philosophy). Her first research monograph entitled What Makes Writing Academic: Rethinking Theory for Practice is forthcoming with Bloomsbury Academic, London

Sharin Shajahan Naomi is Assistant Professor of Gender Studies at Asian University for Women, located in Bangladesh, where she aims to empower women students from I9 different countries of Asia. Naomi completed her Ph.D. from Murdoch University, Australia. The tile of her Ph.D. thesis is Tibetan Buddhism and Feminism in an In-between Space: A Creative-Critical Autoethnography in a Non-Western Woman's Voice. In 20Io, she received the Australian Leadership Award to pursue a Master of Arts in Human Rights from Curtin University, Australia. She received the Climate Cornell Online Fellowship and the USAID Demographic Health Survey Fellowship in 2019. She has published on a diverse range of issues, namely, purdah, Rohingya refugees, human rights, humanitarian law, and public health.

Maria Novotny is Assistant Professor of English at the University of Wisconsin-Milwaukee. As a community-engaged scholar, she co-directs The ART of Infertility, an arts organization that curates exhibits featuring patient perspectives of reproductive loss. Her research on feminist health issues, research as care, and lived experiences of infertility has been published in Computers E Composition, Communication Design Quarterly, Harlot, Peitho, Reflections, and Technical Communication Quarterly.

Brian Paltridge is Professor of TESOL at the University of Sydney and Visiting Professor at the City University of Hong Kong. His research and teaching are in the areas of thesis and dissertation writing, writing for publication, discourse analysis, research methods, and English for specific purposes. He is author of Discourse Analysis (Bloomsbury, 2021), The Discourse of Peer Review (Palgrave Macmillan, 20I7), and, with Sue Starfield, Thesis and Dissertation Writing in a Second Language (Routledge, 2020) and Getting Published in Academic Journals (University of Michigan Press, 2016). He is currently writing a book with Sue Starfield titled Change and Stability in Thesis and Dissertation Writing to be published by Bloomsbury. He is a former editor for the journals English for Specific Purposes and TESOL Quarterly.

Louise Ravelli is Professor of Communication in the School of the Arts and Media at the University of New South Wales, Sidney. She has a long-standing interest in understanding how both language and images work 
in communication contexts, using systemic-functional linguistics and multimodal discourse analysis. Her most recent book is Multimodality in the Built Environment: Spatial Discourse Analysis (Routledge, 2016, with Robert McMurtrie), and she was co-editor with Brian Paltridge and Sue Starfield of Doctoral Writing in the Creative and Performing Arts (Libri UK, 20I4). She is Joint Chief Editor of the journal Visual Communication.

Rachel Robinson is a doctoral candidate in the Department of Writing, Rhetoric, and American Cultures at Michigan State University where she is finishing her dissertation on embodiment, emotions, and imposter syndrome among writing program administrators. Recent publications include the co-edited special issue "(Re)Defining Welcome" of The Peer Review, with Elise Dixon; an article for the WLN: A Journal of Writing Center Scholarship's Digital Edited Colleection (DEC) and a chapter in Affect and Emotion in the Writing Center, both co-authored with Elise Dixon and Lauren Brentnell; and a chapter in An Illness of Her Own: Women and their Writing Processes and Products, co-authored with Elise Dixon.

Machi Sato is Associate Professor in the Center for the Promotion of Excellence in Higher Education at Kyoto University, Japan. She brings sociological and social anthropological perspectives into higher education research and practice. Machi has undertaken research projects on academic identities, doctoral education, and teaching assistant $\&$ learning assistant professional development.

Signe Skov is Ph.D. coordinator at the Doctoral School of People and Technology at Roskilde University and has many years of experience as an academic developer teaching masterclasses for Ph.D. supervisors and facilitating writing retreats for doctoral students and academic staff at the Roskilde University Unit of Academic Development. She has significant experience in developing pedagogies for academic writing and in running workshops and consultations on academic writing for staff, students, and doctoral candidates. In 2019 she completed her Ph.D. thesis, What is a Doctoral Thesis?, at Roskilde University, exploring how Ph.D. supervisors and Ph.D. candidates decide between the monograph or the Ph.D. by publication.

Trixie G. Smith is Director of The Writing Center and Red Cedar Writing Project at Michigan State University and a faculty member in the Department of Writing, Rhetoric \& American Cultures and the Center for Gender in Global Contexts. Recent publications include the collection Graduate Writing Across the Discipline: Identifying, Teaching, and Supporting; articles in Feminist Pedagogies, WAC Partnerships Among Secondary and Post-Secondary Institutions, and Composing Feminist Interventions; and upcoming articles on combatting racism in the writing center and embodiment in the writing cen- 
ter. Her motto is that we're all just humans learning with/from other humans (you know, with bodies, feelings, and lives outside the academy).

Sue Starfield is Professor, School of Education, University of New South Wales (UNSW), Sydney. She teaches and researches doctoral writing and writing for publication and was Director of the Learning Centre at UNSW for I8 years. Publications include Ethnographic Perspectives on Academic Writing (Oxford Uuniversity Press, 2016) with Brian Paltridge and Christine Tardy and Thesis and Dissertation Writing in a Second Language: A Handbook for Students and their Supervisors (Routledge, 2020). She also edits two book series for Routledge with Brian Paltridge: Introductions to English for Specific Purposes and Research in English for Specific Purposes.

Steven Thurlow has taught academic writing since 1999 and doctoral writing since 20I0. Many years ago, he enjoyed work as a professional writer and has a master's degree in this field. He is currently completing an interdisciplinary Ph.D. of Applied Linguistics and Education at The University of Melbourne on how creativity could become a powerful force for change in doctoral education.

Susan van Schalkwyk is Professor in Health Professions Education and Director of the Centre for Health Professions Education in the Faculty of Medicine and Health Sciences at Stellenbosch University. She has more than I5 years' experience in academic staff development, with a specific focus on academic identity. Her work seeks to advance a social justice agenda, with current research in the field of transformative learning theory and the implications it holds for health professions education. She has supervised a number of master's and doctoral students while also focussing on the strengthening of postgraduate supervision and academic writing at this level. 



\section{Re-imagining Doctoral Writing}

What imaginings of the doctoral writer circulate in the talk of doctoral researchers and their supervisors? How do institutional policies and the conventions of particular disciplines shape the ways in which doctoral writing is imagined? Why, and in what ways, has doctoral writing been re-imagined in the twenty-first century? What future imaginings of doctoral writing may be hovering on the horizon? This edited collection has gathered a diverse group of authors-from Aotearoa New Zealand, Australia, Bangladesh, Japan, South Africa, the UK, Denmark, Canada, and the US - to consider these challenging questions during a time in which doctoral education is undergoing enormous transformation. Together, the contributors to this collection explore how the practice of doctoral writing is entangled with broader concerns within doctoral education, including attrition, timeliness, the quality of supervision, the transferability of knowledge and skills to industry settings, research impact, research integrity, and the decolonization of the doctorate.

Cecile Badenhorst is a Professor in the Adult Education/Post-Secondary program in the Faculty of Education at Memorial University, Newfoundland, Canada. She has published in the areas of doctoral education, doctoral writing, graduate writing, thesis/publication writing pedagogies, academic literacies and faculty writing. Brittany Amell is a doctoral candidate at Carleton University in the School of Linguistics and Applied Language Studies. Her doctoral research considers the writing that she and other doctoral students do for their degrees. James Burford is Lecturer in Research Education and Development in the Graduate Research School, La Trobe University, Melbourne, Australia. A critical university studies researcher, he is particularly interested in space, place, affect, and politics in the academic profession and doctoral education.

\section{International Exchanges on the Study of Witing}

Series Editors: Joan Mullin, Magnus Gustafsson, Terry Myers Zawacki, and Federico Navarro

The WAC Clearinghouse

Fort Collins, CO 80523

wac.colostate.edu

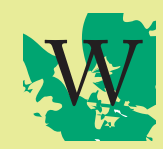

University Press of Colorado

Louisville, Colorado 80027

upcolorado.com 